UNIVERSIDADE DE SÃO PAULO

FACULDADE DE LETRAS, FILOSOFIA E CIÊNCIAS HUMANAS

DEPARTAMENTO DE HISTÓRIA

PROGRAMA DE PÓS-GRADUAÇÃO EM HISTÓRIA SOCIAL

\title{
HISTÓRIA E POESIA:
}

\section{texto e contexto em A rosa do povo (1943-1945), de Carlos Drummond de Andrade}

Fernando Braga Franco Talarico

Orientador: Prof. Dr. Marcos Silva

Dissertação apresentada ao Programa de Pós-

Graduação em História Social do

Departamento de História da Faculdade de

Filosofia, Letras e Ciências Humanas da

Universidade de São Paulo, para obtenção do título de Mestre. 
UNIVERSIDADE DE SÃO PAULO

FACULDADE DE LETRAS, FILOSOFIA E CIÊNCIAS HUMANAS

DEPARTAMENTO DE HISTÓRIA

PROGRAMA DE PÓS-GRADUAÇÃO EM HISTÓRIA SOCIAL

\section{HISTÓRIA E POESIA:}

texto e contexto em A rosa do povo (1943-1945), de Carlos Drummond de Andrade

Fernando Braga Franco Talarico

São Paulo

2006 


\section{AGRADECIMENTOS}

No deserto de Itabira

a sombra de meu pai

tomou-me pela mão.

("Viagem na família”)

Em tempos neoliberais, devo confessar, cordialmente, que a infra-estrutura para que esta pesquisa se cumprisse consistiu em dois - infelizmente - privilégios. O maior, de ordem particular, consistiu no apoio material-moral de Maria Nair Braga Franco Talarico, exemplar professora da Rede Pública, bióloga, mãe querida. O segundo (infelizmente) privilégio foi a bolsa CNPq, concedida em tempos de agonia da esfera pública.

À esfera pública, devoto o meu afeto. À Universidade de São Paulo, Instituição onde conquistei o, infelizmente, privilégio de uma formação integral. Ao Núcleo de Estudos em História Oral, Espaço em que se fez a minha Iniciação Científica e no qual pude conviver com discussões teórico-metodológicas e com a produção sobre o encontro entre historiografia, linguagem e prática política, sob a Coordenação do Professor José Carlos Sebe Bon Meihy. À luta por reforma agrária, apresentada a mim pelos Militantes Negros do Movimento dos Trabalhadores Rurais Sem Terra em Nova Canudos, que nos conferiram a honra de refletir sobre suas Histórias de Vida.

Ao Professor Wilson do Nascimento Barbosa, cuja Historiografia e cuja Prática Docente marcaram fundo. À Professora Ana Maria de Almeida Camargo, pela Confiança. Ao Professor Joaquim Alves de Aguiar, cujo Brilho revelou-me o Pensamento de Antonio Candido. A Antonio Candido. Ao Professor Júlio César Pimentel Pinto Filho e à Professora Norma Seltzer Goldstein, instigantes.

Ao Ô de Casa e ao Cálamo, espaços em que refletíamos e praticávamos.

À docência, por que aprendi.

À bióloga Thais Moreto Teramussi.

A Marcos Silva, pelo Norte.

Em memória de Cláudio Savazzini Talarico. 


\section{RESUMO}

Este trabalho consiste em investigar as relações entre linguagem poética e contexto em A rosa do povo, coletânea de poemas escritos por Carlos Drummond de Andrade entre 1943 e 1945. Entre os 55 poemas da coletânea, há referências, não apenas semânticas, ao Estado Novo, à Segunda Guerra Mundial, ao Nazi-fascismo e à organização problemática do universo urbano-industrial, sempre duma perspectiva que toma partido da Resistência, segundo a ótica do indivíduo lírico. Caracterizada por uma pluralidade temático-formal irredutível a esquemas estruturais, a coletânea encontra a sua coesão na especificidade do lirismo drummondiano. Ao investigarmos aspectos textuais desse lirismo, procuramos compreender os elementos de mediação entre os planos da forma e do significado.

\section{PALAVRAS-CHAVE}

Carlos Drummond de Andrade, A rosa do povo, História e Poesia, Estado Novo (1937-1945), Arte e Engajamento.

\section{ABSTRACT}

This text researchs relationships between poetic speech and context in A rosa do povo (1943-1945). The poems on the book refer to Estado Novo, Second World War, Nazi-fascism and the problematic urban-industrial universe, under the perspective of Resistence and from the lyric person point of view, applying semantic and others means. The book characteristic is a specific lyrism, that cannot to be reduced to structural minds. We here attemp, not to form, or means only, but relationshipa features beetween.

\section{KEY WORDS}

Carlos Drummond de Andrade, A rosa do povo, History and Poetry, Estado Novo (1937-1945), Art and Engagement. 


\section{SUMÁRIO}

INTRODUÇÃ

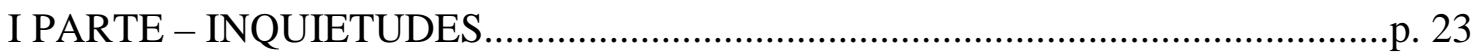

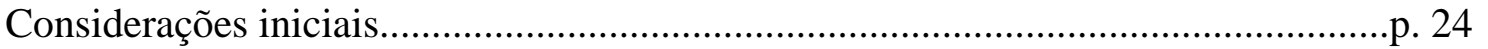

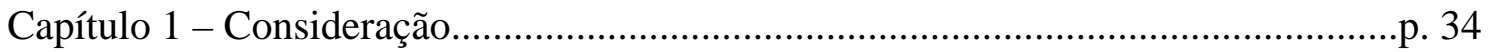

Capítulo 2 - Procura................................................................................................. p. 69

Capítulo 3 - Anúncio........................................................................................... 89

II PARTE - A PROSA DO POETA.................................................................... 130

Capítulo 4 - Na praça de convites (áporo).............................................................p. 131

Capítulo 5 - Uma visão, ou tentativa de, da existência (em nosso tempo).............. p. 167

Capítulo 6 - Uma, duas argolinhas (cidade prevista)...............................................p. 223

DO DOIS AO TRÊS, EM SÍNTESE (CONCLUSÕES)........................................p. 271

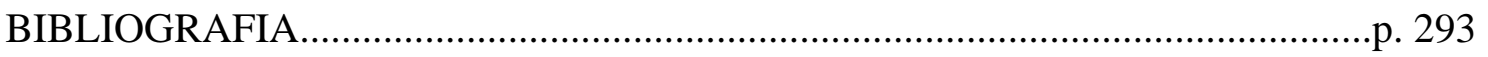




\section{INTRODUÇÃO}


Este trabalho se propõe a analisar A rosa do povo, coletânea de poemas escritos por Drummond entre 1943 e 1945, muitos dos quais circularam de maneira clandestina, antes de que fossem publicados em livro (com a derrocada do autoritarismo do Estado Novo).

Em 1934, Carlos Drummond de Andrade saiu daquela Belo Horizonte tranqüila, traçada com régua meticulosa mas cheia de encantos, que ainda vive em romances de Eduardo Frieiro e Ciro dos Anjos, para ser chefe de gabinete do ministro Gustavo Capanema, no Rio de Janeiro. Veio o golpe de Estado em novembro de 1937 e ele continuou na mesma função, abrindo um capítulo curioso da relação entre o cargo que um escritor exerce e a sua liberdade de pensar e escrever. Ninguém ignorava que Drummond era então simpatizante das posições comunistas, que o Estado Novo proscrevia e perseguia, pois um dos pretextos para a sua instalação foi, justamente, o alegado perigo que elas apresentariam para a Nação, a Ordem, a Família e outras maiúsculas. Assim, o chefe de gabinete do ministro da Educação viveu, no exercício de suas funções, a fase mais ativa da sua militância intelectual de poeta comprometido com ideais de esquerda.

Os governos são mais ou menos elásticos quanto à liberdade de pensamento dos funcionários, de acordo com uma equação instável na qual se equilibram os seus interesses de segurança e a necessidade de recrutar quadros burocráticos capazes. Não esqueçamos que durante o Estado Novo Portinari pôde cobrir com afrescos revolucionários as paredes do novo edifício do ministério, projetado por dois arquitetos de esquerda. E que o próprio ministro dava mão forte a artistas $e$ intelectuais, sem indagar qual era a sua posição ideológica.

De 1940 é o livro Sentimento do mundo, onde a poesia chamada participante ganhou no Brasil uma tonalidade diferente, pois o poeta conseguia exprimir o estado de sua alma de um jeito que importava simultaneamente em negar a ordem social dominante, não faltando poemas nos quais eram visíveis a adesão ao socialismo e a negação do sistema capitalista. Tudo isso em chave de lirismo, como alguma coisa que vem de dentro e existe antes de mais nada enquanto modo de ser; mas revelando tão claramente a posição política, incompatível com as funções de chefe de gabinete, que não foi possível lançar o livro no mercado, naquele momento de censura total. Ele saiu numa tiragem fora do comércio, de cento e cinqüenta exemplares, que, no entanto, se difundiram razoavelmente por meio de cópias feitas para leitores de empréstimo. ${ }^{1}$

${ }^{1}$ Antonio CANDIDO, “Fazia frio em São Paulo", in Recortes, p. 23-24. 
As condições de produção e divulgação de Sentimento do mundo, acima referidas, foram também as condições iniciais de escrita e recepção dos poemas de $A$ rosa do povo. Um desses poemas é o emblemático “O medo”, em que, embora não haja menções explícitas aos eventos dos anos 1940, existe uma relação muito íntima com aquele contexto. Não por acaso, o poema foi dedicado ao crítico literário Antonio Candido, então graduando na Universidade de São Paulo, envolvido em manifestações de natureza tanto militantes quanto intelectuais de combate ao conservadorismo. A epígrafe do poema de Drummond é tomada ao artigo "Plataforma da nova geração", escrito por Antonio Candido:

"Porque há para todos nós um problema sério...

Esse problema é o do medo."2

$\mathrm{O}$ artigo versava sobre

... se há algum dever para o intelectual neste momento. (...)

Aliás, se você me perguntar qual "o" dever específico da nossa geração, eu não saberei responder. Mas se me perguntar qual poderia ser, no meu modo de sentir um rumo a seguir pela mocidade intelectual no terreno das idéias, eu lhe responderei, sem hesitar, que a nossa tarefa máxima deveria ser o combate a todas as formas de pensamento reacionário

Nos domínios da inteligência, Mário Neme, a Reação assume os aspectos mais díspares e mais cavilosos. Se insinua por todo canto. E, num trabalho monumental de obstrução - tanto mais monumental quanto exercido inconscientemente por muitos intelectuais, - breca em todas as curvas a expansão do progresso humano e da inteligência livre.

Não nos compete, evidentemente, assumir uma cor política qualquer $e$ descer à rua, clamando por ação direta. Cada um com as suas armas. A nossa é essa: esclarecer o pensamento e por ordem nas idéias.

E, para quem quiser olhar um pouco em torno de si, as tarefas não faltam. Há umas certas convenções intelectuais, cultivadas carinhosamente pela civilização burguêsa, que, tendo sido uteis a seu tempo, se prolongam hoje em dia como obstáculos à marcha do progresso. A essas convenções, a esses mitos intelectuais, reacionários, guerra sem trégua.

No Brasil há algumas tendências que são ou podem vir a ser altamente perniciosas, apesar de fecundas em alguns aspectos. Se você me perguntar quais são, eu escolherei três, para exemplificar: as filosofias idealistas, a sociologia cultural e a literatura personalista.

(...)

\footnotetext{
${ }^{2}$ Carlos DRUMMOND DE ANDRADE, Poesia completa e prosa, p. 143. Na epígrafe, o artigo citado intitula-se "Plataforma de uma geração". Na cópia que obtivemos junto à Biblioteca Central da Faculdade de Filosofia, Letras e Ciências Humanas da Universidade de São Paulo (cuja única referência é o título da revista: Joaquim, o seu número: 9 e a página: 6), o artigo intitula-se "Plataforma da nova geração".
} 
Relendo estas notas Mário Neme, vejo que acabei quase respondendo à sua pergunta que fica meio gaiata com o sotaque piracicabano. Não faz mal. É uma atitude pessoal, que às vezes me apraz considerar justa. Porque há para todos nós um problema sério, tão sério que nos leva às vezes a procurar meio afoitamente uma "solução": a buscar uma regra de conduta, custe o que custar. Este problema é o do MÊDO. Do mêdo que nos toma a todos de estarmos sendo inferiores à nossa tarefa; ou de não conseguirmos fazer algo de definitivamente útil para o nosso tempo, como, de um modo ou de outro, fizeram os rapazes de Vinte. Você tem algum critério para afastar êste mêdo? Eu não posso bem dizer que tenha mas confesso que êsse combate a tôdas as formas de Reação, que eu apenas sugeri, nos ajudaria muito a ficar livres dêle. E a podermos dormir em paz. ${ }^{3}$

O ensaio "Fazia frio em São Paulo", anos depois, vem a esclarecer aspectos objetivos da relação entre o artigo "Plataforma da nova geração”, de Antonio Candido, e o poema "O medo":

Em 1943 escrevi a Drummond sem conhecê-lo, pedindo descaradamente colaboração para uma revista de jovens de que eu fazia parte. Ele respondeu com extraordinária cortesia, mandando palavras de estímulo e alguns poemas admiráveis, que depois apareceriam quase todos em Rosa do povo. Escolhemos três, que só foram sair dali a um ano, porque a revista passou por longo eclipse. Mas antes de acabar para sempre, no fim de 1944, pôde publicar em primeira mão um dos poemas mais belos e importantes da literatura brasileira contemporânea: PROCURA DA POESIA.

De permeio, no dia 9 de novembro de 1943, os estudantes de direito fizeram contra a ditadura da época uma passeata de protesto, que foi dissolvida a bala pela polícia, com morte de um rapaz, ferimento de vários outros e dezenas de prisões. Como a censura à imprensa e ao rádio era absoluta, resolvi mandar a amigos do Rio uma informação sobre os acontecimentos, a fim de desmascarar ao menos para algumas pessoas responsáveis as deformações previsíveis da versão oficial. Foi o que fiz com a ajuda de uma colega no fim daquela tarde, contando inclusive que o dia estava cinzento, frio, com vento $e$ uma chuvinha ocasional. Tiramos várias cópias a máquina, em papel fino, $e$ mandamos à gente com a qual estávamos ligados, remetendo também uma para Drummond. Pensando na coisa, vejo agora que nunca soube se o relato chegou aos destinatários; mas tempos depois recebi de Drummond a cópia de um poema novo, $O$ MEDO, dedicado a mim e com epígrafe tirada de um artigo meu daquele ano - o que me encheu de um desvanecimento que se pode imaginar. Ora, lá aparecem uns versos que sempre supus alusivos ao relato dos acontecimentos daquela tarde, embora nunca tenha me certificado a respeito com o autor:

Refugiamo-nos no amor, Este célebre sentimento, E o amor faltou: chovia,

\footnotetext{
3 Antonio CANDIDO, "Plataforma da nova geração", grifos do autor.
} 
Ventava, fazia frio em S. Paulo.

Fazia frio em S. Paulo...

Nevava.

Naquele tempo Drummond difundia os seus poemas políticos impublicáveis por meio de cópias remetidas aos amigos; estes, por sua vez, as multiplicavam e elas corriam o país, datilografadas e mimeografadas. Assim se espalharam: DEPOIS QUE BARCELONA CAIR; CARTA A STALINGRADO; TELEGRAMA DE MOSCOU; COM O RUSSO EM BERLIM; MAS VIVEREMOS; VISÃO 1944 - recolhidos mais tarde em Rosa do povo, menos o primeiro. Por este meio o chefe de gabinete exercia uma atividade constante e decidida, animando muita gente com o exemplo de uma participação tão alta, naquele momento que para muitos deveria levar ao "mundo novo" que um dos poemas queria ajudar a nascer. ${ }^{4}$

Em “O medo”, a presença do contexto, muito embora evidente, tende a assumir uma tonalidade mais de alusão que de confissão, ou de referência militante, como se, aparentemente confinado aos limites ditatoriais da censura, o poema restringisse seu discurso a um sussurro, à contenção disciplinar da semântica pela estrutura regular das quadras e da métrica (predominam redondilhas maiores), características que, paradoxalmente, terminam por subverter o silêncio imposto, porque, na verdade, vêemse sistematicamente transfiguradas pela volição lírica (há versos ambíguos, octassílabos ou heptassílabos conforme a escolha rítmica da leitura, assim como há inúmeras subversões rítmicas, no plano das disposições sintáticas, métricas ou estróficas, de modo que o campo semântico do "medo", aparentemente, enrijece a estrutura formal, quando, de fato, essa rigidez não se faz, senão como sugestão irônica, resultando, no final do processo significante, na "superação do verso como unidade autônoma do poema” ${ }^{\text {). }}$

Muitos poemas de A rosa do povo, que não trazem epígrafes ou dedicatórias, e que tampouco figuram ataques tematicamente evidentes ao ethos "burguês" (nem sempre o “engajamento” recorre, de modo explícito, ao nível semântico do discurso, senão a outros planos discursivos), muitos desses poemas, ainda que não explicitamente militantes, invariavelmente guardam alguma relação com o seu contexto primeiro de escrita e de recepção (aspecto essencial do projeto poético), muito embora de modo mediado (em quaisquer dessas situações literárias). A nossa problemática consiste em investigar a forma e o sentido dessas mediações.

\footnotetext{
${ }^{4}$ Antonio CANDIDO, "Fazia frio em São Paulo”, p. 25-26.

5 Antonio CANDIDO, "Inquietudes na poesia de Drummond”, in: Vários escritos, p. 145.
} 
Segundo Iumna Simon, a relação entre texto e contexto, em A rosa do povo, nem sempre se faz nos termos afirmativos de uma linguagem participante (que, ao engajarse, perde em densidade poética, aproximando-se do discurso prosaico, com ganho em informação semântica e perda em informação estética). Como antípoda frente à “participação lingüística”, haveria um movimento contraditório, de caráter antinômico, em que a linguagem, ainda envolvida com o contexto, mas agora em termos negativos, tenderia a recusar a participação na objetividade dos eventos, dirigindo-se, assim, à auto-referenciação e ao hermetismo (com ganho em informação estética e, portanto, perda do caráter comunicativo, positivamente engajado).

É nosso propósito demonstrar, então, que no livro de 1945 explodem, porque se encontram e se negam, as grandes tensões da poesia de Drummond. Se aflora em primeiro plano o problema da comunicação poética, é porque o fator novo do "engajamento" exige, como sua contraparte necessária, um novo tipo de prática artística. Contudo, ao mesmo tempo que se impõe a necessidade de comunicação pela arte, única arma de que o artista dispõe para a luta, propõe-se, e de maneira esplêndida, a poética da negação do assunto, da negação da poesia temática e celebrativa, seja da subjetividade, seja dos acontecimentos exteriores. Consciência da crise da poesia - as possibilidades do fazer poético rejeitam-se, embora procurem se encontrar: negação do "canto" que, contudo, se realiza como canto do presente (o mundo e os homens em sociedade), do passado (a infância e a família) e do eu (o "ser" - passado e presente). Participação, memória e individualismo. Canto simbólico da redenção coletiva e individual. Busca do canto "feito da impureza do minuto" $e$ negação das impurezas, à procura da tensão ideal. Oscilação entre o grito e o silêncio: consciência aguda e angustiada da possibilidade e procura, não menos angustiada, da possibilidade. Autoconsciência e reflexão crítica: poesia que se vai realizando e se indagando sobre sua natureza e função. Negação e criação. Negação que impulsiona a criação. Criação que é consciência de sua própria negação.

(...)

Drummond opta pelo "risco, mas com a incerteza máxima de quem sabe que "A Poesia [sic](...) / elide sujeito e objeto", é “(...) forma definitiva $e$ concentrada / no espaço", e, ao mesmo tempo acredita que, "com suas palavras, intuições, símbolos e outras armas”, poderá ajudar a destruir o "mundo capitalista". Numa hesitação constante entre forma e comunicação, entre fechamento e abertura do discurso, ou - usarmos [sic] a equação sartriana - entre "palavra-coisa” e "palavra-signo". Mas como Haroldo de Campos acentuou com muita agudeza em seu importante e pouco conhecido ensaio "A poesia concreta e a realidade nacional": 
"Alimentar essa dialética sutil é um desafio e uma instigação. Mais do que isto, é o único situar-se válido na poesia de hoje. Dialética entre (sem a esotérica acepção bremmondiana) poesia pura $e$ poesia para, pois - como diz um título de João Cabral (...) duas são as águas, e em ambas a poesia-onça (...) pode beber, pelo menos enquanto durar a circunstância sartriana "poesia contemporânea”, umbilicalmente ligada à precária sociedade de transição em que vivemos".

Tal antinomia é, como se observou anteriormente, a matriz das demais oscilações que percorrem a obra de 45. De [sic] confluência dessas tensões resulta a riqueza e a heterogeneidade dos procedimentos temático-formais praticados nos cinqüenta e cinco poemas do conjunto. ${ }^{6}$

Para Iumna Simon, então,

... A Rosa do Povo representa, como ensaiamos demonstrar, o momento das grandes tensões da trajetória do poeta: ao mesmo tempo que continua a linha de experimentações praticada nos livros anteriores, abre-se ao fator novo da comunicação, instaura a ruptura com esse fator pela radicalidade da proposta de "Procura da Poesia" e antecipa, porque já contém, como reflexão e prática, os procedimentos das fases posteriores. Disso tudo resultam a riqueza e a variabilidade dos procedimentos temático-formais praticados nas cinqüenta e cinco peças constituintes do conjunto. ${ }^{7}$

De fato, a coletânea de 1945 apresenta como característica mais evidente a pluralidade temático-formal, ao longo dos seus cinqüenta e cinco poemas, embora a explicação que o estudo citado propõe para “a riqueza e a variabilidade dos procedimentos temático-formais praticados nas cinqüenta e cinco peças constituintes do conjunto" não nos pareça em conformidade com uma outra tese, ao nosso ver mais adequada, segundo a qual

... entre 1935 e 1959, há nele [na obra de Drummond] uma espécie de desconfiança aguda em relação ao que diz e faz. Se aborda o ser, imediatamente lhe ocorre que seria mais válido tratar do mundo; se aborda o mundo, que melhor fora limitar-se ao modo de ser. E a poesia parece desfazer-se como registro para tornar-se um processo, justificado na medida em que institui um objeto novo, elaborado à custa da desfiguração, ou mesmo destruição ritual do ser e do mundo, para refazê-los no plano estético. Mas este distanciamento em relação ao objeto da criação agrava a dúvida e conduz outra vez o poeta a abordar o ser e o mundo no estado pré-poético de material bruto, que talvez pudesse ter mantido em primeiro plano, conservando o ato criador na categoria de mero registro ou notação.

\footnotetext{
${ }^{6}$ Iumna SIMON, Drummond, uma poética do risco, p. 58-60.

${ }^{7}$ Idem, ibidem, p. 201.
} 
Tais perplexidades se organizam a partir de Sentimento do mundo e José, títulos que indicam a polaridade da sua obra madura; de um lado, a preocupação com os problemas sociais; de outro, com os problemas individuais, ambos referidos ao problema decisivo da expressão, que efetua a sua síntese. O bloco central da obra de Drummond é, pois, regido por inquietudes poéticas que provêm umas das outras, cruzam-se e, parecendo derivar de um egotismo profundo, têm como conseqüência uma espécie de exposição mitológica da personalidade. ${ }^{8}$

Antonio Candido, sem dúvida, constata um dinamismo permanente entre pólos conflituosos, na poesia drummondiana entre 1935 (início da redação dos poemas de Sentimento do mundo) e 1959 (início da redação dos poemas de Lição de coisas). Mas esse dinamismo, para o crítico, institui um movimento integrativo, e não uma oscilação pendular entre pólos antinômicos. Segundo Simon, a riqueza dos procedimentos drummondianos, em 1945, resulta numa tensão permanente entre abertura e fechamento do discurso poético à comunicação, mas, para Antonio Candido, o conflito, de outra natureza, logra alcançar uma síntese, propriamente integrativa, ainda que provisória, da contradição (não nos termos diádicos da antinomia, e sim nos termos triádicos da superação dialética ${ }^{9}$ ), que, assim, se repõe em novos termos, e não nos mesmos.

O que o ensaio de Antonio Candido propõe, com o conceito de “inquietudes”, é um dinamismo integrativo, cuja escala lírica instaura um movimento incessante entre ser e mundo, e uma postura figurativa, insuficiente como "registro", mas tampouco suficiente como desfiguração, e, portanto, permanentemente desfeita como ato perceptivo para refazer-se como expressão, procurando, assim, redimir o eu pelo conhecimento do mundo e o mundo por sua reintegração ao universo volitivo do eu, segundo um refinamento simbólico que, entrementes, não perde nunca o vínculo com a concretude do real (ainda que o refaça).

Essa função redentora da poesia, associada a uma concepção socialista, ocorre em sua obra a partir de 1935 e avulta a partir de 1942, como participação e empenho político. Era o tempo da luta contra o fascismo, da guerra de Espanha e, a seguir, da Guerra Mundial - , conjunto de circunstâncias que favoreceram em todo o mundo o incremento da literatura participante. As convicções de Drummond se exprimem com nitidez suscitando poemas admiráveis, alusivos tanto aos princípios, simbolicamente tratados, quanto aos acontecimentos, que ele consegue integrar em estruturas poéticas de

\footnotetext{
8 Antonio CANDIDO, “Inquietudes na poesia de Drummond”, op. cit., p. 112.

9 Para a discussão teórico-metodológica dos esquemas diádicos e triádicos de pensamento, aplicados à leitura analítica de obras literárias, baseamo-nos sobretudo no ensaio de Antonio CANDIDO, "A passagem do dois ao três", in Revista de história, 1974, vol. L, tomo II, p. 787-800.
} 
maneira eficaz, quase única no meio da aluvião de versos perecíveis que então se fizeram.

Mas do ponto de vista deste ensaio, a sua poesia social não é devida apenas à convicção, pois decorre sobretudo das inquietudes que o assaltam. $O$ sentimento de insuficiência do eu, entregue a si mesmo, leva-o a querer completar-se pela adesão ao próximo, substituindo os problemas pessoais pelos problemas de todos.

Assim, pode rever a escala da personalidade em relação ao mundo (...) O burguês sensível se interpreta em função do meio que o formou e do qual, queria ou não, é solidário. (...) O desejo de transformar o mundo, pois, é também uma esperança de promover a modificação do próprio ser, de encontrar uma desculpa para si mesmo. E talvez esta perspectiva de redenção simultânea explique a eficácia da poesia social de Drummond, na medida em que (Otto Maria Carpeaux já o disse faz tempo) ela é um movimento coeso do ser no mundo, não um assunto, mediante o qual um vê o outro. O seu cantar se torna realmente geral porque é, ao mesmo tempo, profundamente particular.

\section{(...)}

Isto não aplaca a inquietude, mas favorece a noção de que o eu estrangulado é em parte conseqüência, produto das circunstâncias; se assim for, o eu torto do poeta é igualmente uma espécie de subjetividade de todos, ou de muitos, no mundo torto. Mesmo que não contribua para redimir o personagem que fala na primeira pessoa, a destruição do velho "mundo caduco" poderia arrastar consigo as condições que geram consciências estranguladas, como a sua. ${ }^{10}$

Desse modo, nos parece legítimo sustentar que, embora a coerência da poética drummondiana de A rosa do povo seja a pluralidade temático-formal, há, por sob essa multiplicidade de temas e de formas, a integração literária de aspectos, por vezes contraditórios, mas de todo modo coesos, segundo a escala lírica. Essa é uma das conclusões que importa sublinhar, na apropriação que pretendemos do conceito de “inquietudes", e que, de maneira fundamental, contribui para configurar o universo complexo do sistema simbólico drummondiano.

Num estudo, cujo objeto consiste na coletânea de 1951 (Claro enigma), e que, entretanto, busca retomar, com preocupações comparativas, aspectos fundamentais de $A$ rosa do povo, Vagner Camilo observa que

Claro enigma foi considerado com razão o livro mais rigorosa $e$ ostensivamente arquitetado de Drummond. Esse rigor evidencia-se de imediato na ordenação dos poemas em seções ou cadernos (seis ao todo), que parece antecipar a triagem promovida por Drummond na Antologia Poética de 1962, de acordo com a tônica de suas composições, como sugere Francisco Achcar em estudo introdutório ao exame da obra. ${ }^{11}$

\footnotetext{
${ }^{10}$ Antonio CANDIDO, “Inquietudes na poesia de Drummond”, op. cit., p. 125-127.

${ }^{11}$ Vagner CAMILO, Drummond: da Rosa do Povo à Rosa das Trevas, p. 164.
} 
Em nota de rodapé, o autor aponta que

Como diz Sebastião Uchoa Leite, este é o livro mais "isolado" da obra de Drummond, "o mais encerrado em sua própria trama, o mais esquematizado, o livro mais livro (ao passo que Rosa do Povo talvez seja o mais não-livro). "12

Cabe supor, entretanto, que a estrutura "não-livro" (ou, comparativamente, “menos livro”) de A rosa do povo, ao não apresentar divisão estrutural de nenhuma natureza (nem formal, nem temática, nem de nenhuma espécie) e ao evocar tantas outras obras (as do próprio poeta e as de outros artistas e intelectuais, num diálogo semântico mas, sobretudo, formal), essa estrutura "não-livro", em vez de configurar uma falta de rigor artístico, tem, ao contrário, um fundamento lírico rigoroso, cuja especificidade é o dinamismo e a pluralidade, desde o plano estrutural.

É também a pluralidade que, a seu modo, o estudo de José Guilherme Merquior identifica como característica de A rosa do povo (obra que o autor inclui, juntamente com José, de 1941-1942, no período conceituado como “o meio-dia da escrita”), numa abordagem direcionada sobretudo ao estilo:

Com José e A Rosa do Povo, isto é, com sua poesia composta de 1941 a 45, Drummond traz ao modernismo três conquistas decisivas para o desenvolvimento da literatura brasileira: um realismo social excepcionalmente penetrante, muito acima do lirismo declamatório da poesia engajada; uma poesia metapoética, nutrida de uma espécie de reflexão introspectiva da escrita; um lirismo, enfim, de interrogação existencial, preludiando o desenvolvimento do poema filosófico que caracterizará os livros posteriores como Claro Enigma.

É óbvio que se [sic] essas contribuições ficariam no nível de simples curiosidades temáticas, se o estilo de Drummond não as tivesse tornado matéria-prima de um notável amadurecimento técnico. O autor de Alguma Poesia, modernista radical, era sobretudo uma voz original; o autor de A Rosa do Povo, conservando essa originalidade, torna-se o miglior fabbro da poesia modernista.

De modo particular, o poema longo, tentado por Mário de Andrade, que o modernismo tendia a usar em substituição às formas curtas da canção romântica e do soneto de tradição parnasiana, ganha em Drummond um mestre incontestável.

Vindo após a "escorregadela" neo-romântica de Sentimento do Mundo, o lirismo de A Rosa do Povo se divide entre a ótica grotesca em "estilo mesclado" e um estilo "puro" não menos moderno. Desencadeia-se, assim, uma verdadeira classicização do modernismo, análoga, em certos aspectos, à

\footnotetext{
${ }^{12}$ Idem, ibidem, p. 164 (trata-se da nota 20).
} 
evolução por volta de 1930, do estilo poético de um T. S. Eliot, após a Stillmischung de The Waste Land. Sabe-se que uma tal classicização nada tem de "reacionária" do ponto de vista da técnica do verso. Em Drummond - e aqui termina a semelhança com Eliot - o novo estilo "puro" não trouxe consigo sequer uma "restauração" ideológica. Bem ao contrário: como o provam sua "metapoesia" e seu lirismo filosófico-existencial, ambos escritos em estilo "puro" - a modernidade e a autonomia intelectual do lirismo drummondiano não cessam de crescer. ${ }^{13}$

As minuciosas descrições de aspectos estilísticos de A rosa do povo que o estudo de Merquior estabelece demonstram, apesar da sua fluência analítica, saltos interpretativos pouco mediados, momentos em que, da consideração atenta aos aspectos sincrônico-textuais, derivam sobreposições apressadas, ao contexto de escrita, do contexto de interpretação. A verificação da pluralidade temático-formal, por Merquior, serve a julgamentos de valor sobre o que é “melhor” ou “pior” em Drummond segundo critérios estéticos que mal escondem pressupostos político-ideológicos, além de recursos teórico-metodológicos calcados numa filosofia da história de caráter teleológico. O grande problema do estudo não é de ordem analítica, mas o salto da descrição dos aspectos do estilo à interpretação dos significados "sociológicos” e “estéticos”.

Procuraremos, em nossa investigação, compreender a multiplicidade temáticoformal de A rosa do povo, não segundo critérios exclusivamente valorativos, nem a partir de recortes, ou apenas temáticos, ou exclusivamente formais, mas com a preocupação de identificar os elementos de mediação entre texto e contexto. Queremos evitar, igualmente, pressupostos que estabeleçam, nas relações complexas e devidamente mediadas entre as dimensões textuais e as dimensões contextuais, a anterioridade de uma esfera sobre outra. Apropriando-nos da tese sobre as "inquietudes" drummondianas, entendemos que a coerência da coletânea consiste no fato de sua pluralidade de temas e formas derivar do "núcleo poético" de uma subjetividade lírica inquieta, que, por meio de uma aguda consciência lingüística e da necessidade subjetiva de redimir os aspectos subjetivos e objetivos do real, procura desfazer os vínculos entre eu e mundo, para refazê-los em outros e mais libertário termos.

Alcides Celso Oliveira Villaça escreve, a propósito do "Poema de sete faces” (mas ampliando o alcance de suas conclusões para toda a coletânea a que pertence e, de certo

\footnotetext{
${ }^{13}$ José Guilherme MERQUIOR, Verso universo em Drummond, p. 121, grifos do autor.
} 
modo, a toda a obra, uma vez que procura conceituar o que seja, na poética drummondiana, o "gauchismo”, no momento de sua gênese):

Reconhecidas as faces em seu movimento dramático de falas e inflexões (e não numa ilusória imobilidade de colagem), qualifica-se também o tempo lírico que dá ritmo à unidade possível do poema. Resta investigar essa qualidade na ação que já transcende o plano morfológico, reconhecendo-lhe a repercussão de sentido num plano cultural mais amplo. Uma questão rudimentar, mas também decisiva, coloca-se sempre diante de um poema intimista: como foi mesmo que ganhou o nosso interesse? A resposta não se completa com a justificativa do gosto, também este, aliás, uma intrigante questão cultural; a resposta depende da sondagem de confluências em geral pouco visíveis, mas sem dúvida estruturais, entre a fala do poeta e a receptividade emotiva e intelectual do público nele implicado. Sem subestimar a pluralidade dessas confluências e a diversa natureza delas, não desistamos de buscar reconhecê-las.

Sabe-se que a poesia lírica projeta contra qualquer outra ordem de discurso sua $\mathrm{voz}$ muito particular, expressão de uma verdade íntima que podemos reconhecer com surpresa. Nessa surpresa do reconhecimento reside o efeito do paradoxo do poema lírico, menos paradoxal, porém, se admitimos a correspondência da intimidade nossa com uma verdade mais geral, no interior de uma "corrente subterrânea coletiva" (Adorno). Que reconhecimento específico permite-nos compartilhar com interesse da expressão sedutora do "Poema de sete faces"?

Partindo da evidência: no "clima" dele reina uma instabilidade psicológica que impede a fixação da perspectiva única, descaracterizando-se exatamente o sentido mais tradicional de lirismo: sentimento que emerge do individuum, isto é, do ser indivisível, uno, irredutível. Multiplicando-o em distintas faces a partir de um simulacro de autobiografia, Drummond dota o seu sujeito da identidade complexa de quem está sempre fora de alguma ordem de expectativa, valendo-se para isso de uma expressão que tampouco repousará na exclusividade de um estilo. Até aqui a pluralidade não espanta, pois confina com a atitude modernista que tem a fragmentação como critério. O ganho está em ultrapassar a mera atitude e encarnar com peso realista a necessidade escancarada das personae, movimentadas pela ambigüidade essencial do sujeito: um amálgama de confissões e ironias. Numa encruzilhada histórico-estética em que múltiplos e contraditórios valores parecem disponíveis, a falta do rosto pessoal é preenchida por uma sucessão de seus esboços, desierarquizando-se planos e temas, sensações e sentimentos, conceitos e imagens. A potencialidade do verso livre modernista, com tudo o que ele implica, é acionada em seu dispositivo fulminante: aquele que faz explodir, no interior da linguagem, a ilusão de um ponto de vista unificador. Abre-se ao sujeito a traiçoeira possibilidade das multiplicações - "liberdade" a que cada poeta não deixa de estar condenado.

Tal liberdade Drummond a exercita com o "grão de angústia” de seu humor crítico; integra-a numa biografia possível, a que não faltam premonições dos grandes temas de sua poesia. O leitor mais íntimo de sua obra reconhecerá neste poema, correndo sob a linguagem, uma história de motivos bem familiares: a maldição original (como a lançada pelos ancestrais 
no extraordinário "Os bens e o sangue”), a inquietude das paixões amorosas (como em "Tarde de maio" ou "Campo de flores"), a perda da ordem provinciana (como em "Confidência do itabirano"), o contraponto entre o ritmo da intimidade e o da cidade grande (como em "A bruxa"), os dilemas da classe média e do poeta funcionário público (como em "A flor e a náusea”), a culpa íntima e irresgatável (como em “A mão suja”), a ilusão da decantada conciliação brasileira (como em "Hino Nacional”). ${ }^{14}$

A partir do ensaio de Villaça, ocorre uma espécie de virada na fortuna crítica drummondiana, com a síntese de diversas contribuições, tornadas, segundo a apropriação do ensaísta, complementares. A compreensão do gauchismo drummondiano (segundo a qual há sempre um mesmo personagem, sob a escala do indivíduo lírico, porém expresso por uma multiplicidade inesgotável de manifestações figurativas, a configurar um sujeito de muitas “faces”, “verdadeiro em todas e incompleto em cada uma”) tem um poder de esclarecimento que transcende o primeiro poema e a primeira coletânea de Drummond, demonstrando uma lucidez aguda também frente a A rosa do povo.

Podemos dizer, em síntese, que o nosso objeto de pesquisa é um sistema simbólico complexo, que estabelece uma problemática em diversos níveis: no nível da sua constituição interna, ou significante (o nível da materialidade do texto); no nível dos significados (que diversas leituras críticas vêm atribuindo à obra, e que, de certo modo, já não mais se dissociam do seu significado literário, e cuja razão de ser consiste no debate de idéias, encontrando como ponto de partida e de chegada a materialidade, a um tempo concreta e simbólica, do texto); no nível das relações entre a interioridade textual e a exterioridade contextual (o que constitui um dos fundamentos da obra de 1945 já no plano do enunciado, mas cujo vínculo propriamente literário, para explicar-se, requer que se compreenda o que, no plano sincrônico do texto, é mediação entre história e linguagem).

\footnotetext{
${ }^{14}$ Alcides Celso Oliveira VILLAÇA, "Capítulo drummondiano”, in Lendo poetas brasileiros, p. 26-29, grifos do
} autor. 
Haveria, ainda, diversos outros níveis que, considerados, contribuiriam para enriquecer a compreensão de A rosa do povo e de toda a obra drummondiana, tais como os usos concretos que os poemas de Drummond têm recebido em contextos os mais diversos, não apenas aqueles restritos às discussões literárias especializadas, mas a demais práticas sociais (tais como a apropriação, por um réu injustamente acusado, do verso-refrão “E agora, José?”, no momento em que foi absolvido ${ }^{15}$, ou então a contaminação, por parte de alguns estudos sociológicos, dos significados literários drummondianos em razão da sua situação biográfica objetiva de burocrata, ou de filho de "Coronel”16). A consideração desses outros usos, no entanto, não consiste no foco de nosso estudo.

Na medida em que a arte é (...) um sistema simbólico de comunicação inter-humana, ela pressupõe o jogo permanente de relações entre os três [autor, obra e público, ou comunicante, comunicado e comunicando], que formam uma tríade indissolúvel. O público dá sentido e realidade à obra, e sem ele o autor não se realiza, pois ele é de certo modo o espelho que reflete a sua imagem enquanto criador. Os artistas incompreendidos, ou desconhecidos em seu tempo, passam realmente a viver quando a posteridade define afinal o seu valor. Deste modo, o público é fator de ligação entre o autor e a sua própria obra.

A obra, por sua vez, vincula o autor ao público, pois o interesse deste é inicialmente por ela, só se estendendo à personalidade que a produziu depois de estabelecido aquele contacto indispensável. Assim, à série autor-públicoobra, junta-se outra: autor-obra-público. Mas ou autor, do seu lado, é intermediário entre a obra, que criou, e o público, a que se dirige; é o agente que desencadeia o processo, definindo uma terceira série interativa: obraautor-público.

Um estudioso contemporâneo, tratando da linguagem literária, exprime bem este fato, ao dizer que a invenção da escrita "tornou possível a um ser humano criar num dado tempo e lugar uma série de sinais, a que pode reagir outro ser humano, noutro tempo e lugar. Resulta que o escritor vê apenas ele próprio e as palavras, mas não vê o leitor; que o leitor vê as palavras e ele próprio, mas não vê o escritor; e um terceiro pode ver apenas a escrita, como parte de um objeto físico, sem ter consciência do leitor nem do escritor. Isso pode fazer com que o escritor suponha, irrefletidamente, que as únicas partes do processo sejam a primeira e a segunda; e o leitor suponha que o processo consiste na segunda e terceira; e um crítico irrefletido, que a segunda parte é tudo. (...) Mas (a) verdade básica é que o ato completo da linguagem depende da interação das três partes, cada uma das quais afinal só é inteligível (...) no contexto normal do conjunto". ${ }^{17}$

\footnotetext{
${ }^{15}$ Cf. Geneton MORAES NETO, O dossiê Drummond, p. 55.

${ }^{16}$ Cf. Sérgio MICELI, Intelectuais e classe dirigente no Brasil e Simon SCHWARTZMANN, Tempos de Capanema.

17 Antonio CANDIDO, "A literatura e a vida social", in Literatura e sociedade, p. 38-39.
} 
Não pretendemos abordar a obra em si, como objeto em sua realidade exclusivamente sincrônica, embora entendamos esse tipo de abordagem como algo pertinente e necessário; segundo as necessidades da problemática que identificamos, entretanto, importa tomar a obra sob a ótica de sua(s) historicidade(s), isto é, segundo relações entre as suas possibilidades significantes e a compreensão de seus significados, o que implica considerar, mediatamente, os contextos de leitura (o nosso, inclusive) e de produção (integrado às dimensões textuais). É importante frisar que essa problemática não resulta do arbítrio na escolha de uma perspectiva epistemológica, mas de sugestões da própria obra poética.

A realidade da obra literária não se faz em si, mas em infinitas possibilidades de leitura, levando em consideração os seus elementos significantes; portanto, as leituras críticas, ao discutirem entre si, passam a interferir na construção dos significados literários da obra. Essa perspectiva importa na compreensão de A rosa do povo em especial, porque se encontra, como figura e como figuração, já no plano da textualidade. A obra, ao construir imagens sobre si mesma (entre essas imagens, a da "flor", ou “rosa”), recusa-se como objeto em si, e exige situar-se como ato discursivo, historicamente identificado. Sendo assim, cientes da historicidade da obra, desde o plano significante, como também no plano da (re)construção de seus significados pela recepção crítica, abordaremos os planos dos significados possíveis e das sugestões significantes de maneira dinâmica, objetivando a compreender a obra como mediação e como realidade apenas relativamente autônoma. 4

Diante da complexidade literária de A rosa do povo, e tendo como objetivo compreender o seu fundamento artístico, com vistas a interpretar as mediações entre a criação poética e o universo de problemas de ordem contextual, recorreremos à seguinte estrutura de investigação: uma Primeira Parte, cujo enfoque é a análise interna de alguns poemas fundamentais, segundo o conceito das inquietudes líricas drummondianas, proposto por Antonio Candido; e uma Segunda Parte, em que se acompanham alguns percursos líricos, com a preocupação de compreender a poética participante, não como “tema” imediato, mas como um problema cuja representação filtra-se pela escala figurativa. 
Na Primeira Parte, embora o núcleo de investigação sejam os elementos significantes, e embora a estratégia metodológica consista em leituras analíticas em profundidade, isto não significa que a preocupação com o “engajamento” fique em segundo plano, porque, ao contrário, recusaremos o pressuposto teórico de que o "engajamento" instaura, como tônica do discurso, a comunicação, com recurso a funções lingüísticas próprias à “prosa”, a implicar perda da densidade discursiva (característica do discurso predominantemente “poético”). Nessa Primeira Parte, nossa preocupação será alcançar, no universo estético, os elementos significantes que concorrem, num discurso denso, para a construção dos significados. Em outras palavras, a seleção de aspectos formais já encaminha, no momento da análise, uma direção interpretativa; conscientes disso, empregaremos recursos teórico-metodológicos cujos pressupostos contemplem as relações entre texto e contexto, de maneira mediada.

Da mesma maneira, a Segunda Parte, embora não mais invista na análise cerrada de aspectos internos do texto, e sim na interpretação de percursos líricos que aproximem textos diversos, ainda assim não se pretende perder de vista o fundamento poético do lirismo drummondiano, quando, ao contrário, é fundamental ter em mente que a coerência de A rosa do povo guarda um vínculo estreito com a sua característica coesiva, qual seja, um lirismo muito especificamente drummondiano, que se pode conceituar como gauchismo, nos termos de Alcides Villaça.

Sendo assim, na Primeira Parte, cada um dos três capítulos recortará poemas em que a figuração metalingüística constrói imagens e experiências acerca do universo literário das representações. Tomadas, menos como sugestões semânticas, e mais como construção significante, essas experiências permitirão analisar e interpretar poéticas que, a seu modo, sintetizam todo o universo artístico de A rosa do povo. Nessas construções, o próprio ato figurativo, representando a si próprio, traz indícios estéticos da relação entre o universo textual e aspectos contextuais; com ser a superação dialética dos percursos conflituosos duma subjetividade todo-retorcida, esses metapoemas poderão esclarecer os elementos propriamente líricos que conferem coesão à coletânea, desde que respeitados em suas contribuições à coerência da obra (qual seja, a sua pluralidade irredutível).

Já a Segunda Parte, com o respaldo da investigação sobre os fundamentos artísticos de A rosa do povo, investirá prioritariamente em acompanhar alguns percursos líricos ao longo da obra, o que vale dizer: neste momento, os poemas serão abordados, não mais de acordo com uma leitura exaustiva, mas segundo preocupações temáticas, 
que se desdobram nos diálogos possíveis entre textos diversos, no contexto, a um tempo literário (a coletânea) e extra-literário (o “tempo presente”) de A rosa do povo. De início, importará acompanhar as projeções do mundo sobre a interioridade do eu, para, em seguida, acompanhar as projeções volitivas da subjetividade lírica, em seus deslocamentos pelo mundo, ambos os movimentos filtrados por recursos figurativos de natureza metalírica, que serão alvos de um terceiro momento dessa investigação.

Por fim, nas Conclusões, retomaremos as questões que acabamos de apresentar, objetivando responder sobre a natureza do envolvimento textual em aspectos contextuais (problemática que se pode conceituar como "engajamento”, ou participação poética). Em que medida o “engajamento" poético de $A$ rosa do povo organiza o universo textual, e de que modo essa organização se faz, “concretamente”? Quais os elementos de mediação entre o universo estético drummondiano e o contexto a que ele, explícita ou implicitamente, faz referência, e quais os seus significados, diante das convenções lingüísticas e extra-lingüísticas? Com vistas a responder essas perguntas, dedicamo-nos à leitura da coletânea de 1945. 


\title{
PRIMEIRA PARTE
}

\author{
Inquietudes
}




\section{CONSIDERAÇÕES INICIAIS}

O primeiro poema de A rosa do povo é “Consideração do poema”; o segundo é “Procura da poesia”. Desde o título, evidencia-se que são poemas metalingüísticos. Diversos outros poemas do livro praticam a metalinguagem, muito embora essa possa não ser a tônica em todos eles. Há metalinguagem em: “Carrego comigo”, “Ontem”, "Fragilidade”, “Anúncio da rosa”, “O mito”, “O elefante”, “Carta a Stalingrado”, “Indicações”, “Os últimos dias”, "Mário de Andrade desce aos infernos”, “Canto ao homem do povo Charlie Chaplin”, entre outros.

Conforme apontou Antonio Candido, a metapoesia é fundamental para a poética drummondiana, uma vez que é no plano da linguagem que se opera a síntese das “inquietudes":

Já ficou dito que todas essas inquietações (material sobre que trabalha o poeta) adquirem validade objetiva pelo fato de se vincularem a uma outra: a meditação constante e por vezes não menos angustiada sobre a poesia. ${ }^{18}$

Não é de se estranhar que os poemas de A rosa do povo pratiquem, em maior ou menor grau, a metalinguagem. Trata-se de uma estratégia fundamental dentro do tema nuclear das “inquietudes” em Drummond.

... a polaridade de sua obra madura; de um lado, a preocupação com os problemas sociais; de outro, com os problemas individuais, ambos referidos ao problema decisivo da expressão, que efetua a sua síntese. O bloco central da obra de Drummond é, pois, regido por inquietudes poéticas que provêm umas das outras, cruzam-se e, parecendo derivar de um egotismo profundo, têm como conseqüência uma espécie de exposição mitológica da personalidade. ${ }^{19}$

Na Antologia poética ${ }^{20}$ publicada em 1962, o poeta seleciona e agrupa sob a denominação de “Poesia contemplada” (também denominada “A própria poesia”) alguns dos metapoemas dispersos pela obra ${ }^{21}$.

\footnotetext{
18 Antonio CANDIDO, "Inquietudes na poesia de Drummond", in Vários escritos., p. 134.

${ }^{19}$ Idem, ibidem, p. 134.

20 Carlos DRUMMOND DE ANDRADE, Antologia poética, p. 153-160. O recurso à comparação entre as estruturas de $A$ rosa do povo e da referida Antologia nos foi sugerida pela análise de Vagner CAMILO em "O rigor da arquitetura", in Drummond: da rosa do povo à rosa das trevas, p. 164-167).
} 
Ao organizar este volume, o autor não teve em mira, propriamente, selecionar poemas pela qualidade, nem pelas fases que acaso se observem em sua carreira poética. Cuidou antes de localizar, na obra publicada, certas características, preocupações e tendências que a condicionam ou definem, em conjunto. A Antologia lhe pareceu assim mais vertebrada e, por outro lado, espelho mais fiel.

Escolhidos e agrupados os poemas sob esse critério, resultou uma Antologia que não segue a divisão por livros nem obedece a cronologia rigorosa. O texto foi distribuído em nove seções, cada uma contendo material extraído de diferentes obras, e disposto segundo uma ordem interna. O leitor encontrará assim como pontos de partida ou matéria de poesia: 1) O indivíduo; 2) A terra natal; 3) A família; 4) Amigos; 5) O choque social; 6) $O$ conhecimento amoroso; 7) A própria poesia; 8) Exercícios lúdicos; 9) Uma visão, ou tentativa de, da existência.

Algumas poesias caberiam talvez em outra seção que não a escolhida, ou em mais de uma. A razão da escolha está na tônica da composição, ou no engano do autor. De qualquer modo, é uma arrumação, ou pretende ser. ${ }^{22}$

Como não se trata duma poética do assunto e, sim, duma poética de processo, em que do núcleo subjetivo das “inquietudes” deriva a riqueza de temas, não é possível encontrar blocos temáticos definitivos, visto que todos os problemas cruzam-se e interpenetram-se.

... entre 1935 e 1959, há nele [na poesia de Drummond] uma espécie de desconfiança aguda em relação ao que diz e faz. Se aborda o ser, imediatamente lhe ocorre que seria mais válido tratar do mundo; se aborda o mundo, que melhor fora limitar-se ao modo de ser. E a poesia parece desfazer-se como registro para tornar-se um processo, justificado na medida em que institui um objeto novo, elaborado à custa da desfiguração, ou mesmo destruição ritual do ser e do mundo, para refazê-los no plano estético. Mas este distanciamento em relação ao objeto da criação agrava a dúvida e conduz outra vez o poeta a abordar o ser e o mundo no estado pré-poético de material bruto, que talvez pudesse ter mantido em primeiro plano, conservando o ato criador na categoria de mero registro ou notação. ${ }^{23}$

(...)

Assim, pode rever a escala da personalidade em relação ao mundo (...) O burguês sensível se interpreta em função do meio que o formou e do qual, queria ou não, é solidário. (...) O desejo de transformar o mundo, pois, é também uma esperança de promover a modificação do próprio ser, de encontrar uma desculpa para si mesmo. E talvez esta perspectiva de redenção simultânea explique a eficácia da poesia social de Drummond, na medida em

\footnotetext{
21 São eles: "O lutador", de José (1942); "Procura da poesia”, d'A rosa do povo (1945); "Brinde no banquete das musas", de Fazendeiro do ar (1954); "Oficina irritada", de Claro enigma (1951); "Poema-orelha", de A vida passada a limpo (1959); "Conclusão", de Fazendeiro do ar.

22 Carlos DRUMMOND DE ANDRADE, op. cit., p. 7.

23 Antonio CANDIDO, op. cit., p. 112.
} 
que (Otto Maria Carpeaux já o disse faz tempo) ela é um movimento coeso do ser no mundo, não um assunto, mediante o qual um vê o outro. O seu cantar se torna realmente geral porque é, ao mesmo tempo, profundamente particular. $^{24}$

Não é apenas retórica a observação de Drummond, quando afirma que "algumas poesias caberiam talvez em outra seção que não a escolhida, ou em mais de uma”: ele explicita que a estrutura proposta não é absoluta, senão relativa a critérios arbitrários, e que, portanto, admite o “engano”. “A razão da escolha está na tônica da composição, ou no engano do autor. De qualquer modo, é uma arrumação, ou pretende ser.”: com o chiste, o poeta reafirma, na condição de autor, a sua persona de "gauche”, mas essa postura, para além do simples humorismo retórico, guarda coerência profunda com a unidade processual da obra, que não permite agrupar os poemas de acordo com a temática, senão de maneira provisória ${ }^{26}$. Muitos poemas poderiam compor, simultaneamente, mais de uma seção; “algumas poesias caberiam talvez em outra seção que não a escolhida, ou em mais de uma”.

Em A rosa do povo, não há divisão explícita de espécie alguma: todos os cinqüenta e cinco poemas formam um só grupo, sem subdivisões, o que certamente importa na construção de sentidos. Na Antologia poética, a seção "Poesia contemplada” não comporta poemas como “Anúncio da rosa” e "O elefante”, reunidos em “Amaramaro” (ou “O conhecimento amoroso”), embora sejam poemas em que a presença da metalinguagem é crucial.

Iumna Simon, em seu estudo Drummond: uma poética do risco, adota categorias para classificar poema a poema de A rosa do povo, e afirma haver-se inspirado na referida Antologia de Drummond.

\footnotetext{
${ }^{24}$ Idem, ibidem, p. 126-127.

${ }^{25} \mathrm{Na}$ representação de si através da persona lírica gauche, mais que uma imagem literária, encontra-se a coerência do projeto poético drummondiano, segundo Afonso Romano de SANT'ANNA (in Drummond, o Gauche no tempo). Para o crítico, tal projeto consiste no descentramento do eu lírico, como que para observar a si próprio, de maneira, a um tempo, reflexivamente distanciada e afetivamente próxima. Da representação dramática do deslocamento desse eu em direção à sua interioridade ou, então, à sua exterioridade, resultariam os diversos momentos da obra drummondiana, que muitos críticos procuraram caracterizar como fases temático-formais, mas que Sant'Anna prefere explicar pelo conceito de gauchismo, válido para qualquer momento da trajetória poética de Drummond. Marcas estilísticas do gauchismo seriam o emprego da terceira pessoa em lugar da primeira, configurando uma espécie de diálogo do eu consigo mesmo, através de aparentemente objetivar-se, ou então de ocultar-se sob personagens como o Carlitos de Charles Chaplin (refigurado por Drummond) ou José, do poema drummondiano homônimo.

${ }^{26}$ Davi ARRIGUCCI Jr. (in Coração partido, p. 33-34) observa que, na obra drummondiana, "além de propiciar a montagem e desmontagem da palavra, cujo aspecto lúdico reconduz por si mesmo, como se sabe, à fonte originária da criação verbal que é a poesia, o chiste atua como um procedimento de articulação no poema entre as muitas faces que constituem a pluralidade do mundo. No fundo, ele é capaz de unir o inconsciente e o consciente, levando o sentimento à lucidez da consciência, pelo viés da ironia e as voltas da reflexão.”
} 
Embora A Rosa do Povo não seja uma obra subdivida em partes, como ocorre com Claro Enigma e Lição de Coisas (e também com as obras mais recentes), é possível agrupar os poemas segundo afinidades temáticas e/ou formais. É preciso considerar, porém, que esses conjuntos não são facilmente apreensíveis, pois apresentam-se complexamente entrelaçados, sendo a seqüencia dos poemas de um conjunto, não raro, seccionada pela inserção de um ou mais poemas pertencentes a outros conjuntos. Todavia, há certos momentos em que essas afinidades temático-formais são mais perceptíveis porque ocorrem de forma compacta, ou seja, em poemas sucessivos que constituem verdadeiros blocos de concentração de tais procedimentos.

A reunião dos poemas em grupos, de acordo com a "tônica da composição" (ou com o "engano do autor", diz o poeta), é uma prática já utilizada pelo próprio Drummond, ao organizar sua Antologia Poética. A adoção desse mesmo critério em relação ao livro de 45 permite-nos atestar a variabilidade característica dessa obra, que, em geral, é considerada como exclusivamente participante. Pudemos organizar os conjuntos de acordo com os seguintes constantes:

$$
\begin{aligned}
& P=\text { a própria poesia ("poesia contemplada”) } \\
& E=\text { engajamento ("na praça de convites") } \\
& F=\text { fechamento do discurso } \\
& M=\text { memória ("família, terra natal”) } \\
& I=\text { indivíduo ("um eu todo retorcido") } \\
& A=\text { amor ("amar-amaro") } \\
& D=\text { dramático ("Ato") } \\
& C=\text { amigos ("cantar de amigos”) }{ }^{27}
\end{aligned}
$$

Em nota de rodapé, a autora explica:

Encontram-se entre parênteses os nomes dados por Drummond às "seções" ou agrupamentos de textos constantes de sua Antologia Poética. Observe-se que reunimos o tema da família e da terra natal em um só conjunto, bem como não incluímos algumas outras seções da antologia ("uma, duas argolinhas" e "tentativas de exploração e de interpretação do estar-nomundo"). Atente-se ainda para o fato de que, à diferença dos outros, o nome do conjunto $F$ (fechamento do discurso) leva em conta as afinidades formais, embora ocorra com freqüência nos poemas desse conjunto a tematização do tempo. $^{28}$

A autora trabalha com oito categorias, enquanto o poeta estabelece nove, e explica que duas seções foram suprimidas, enquanto a fusão de outras duas originou a categoria "M= memória"29. Ocorre, no entanto, que há duas novas seções que não

\footnotetext{
27 Iumna SIMON, Drummond: uma poética do risco, p. 60, grifos nossos.

${ }^{28}$ Idem, ibidem, p. 60-61, grifos nossos. Trata-se da nota 34.

${ }^{29}$ Essa categoria que Iumna cria é interessante, cabe analisá-la mais detidamente. A problemática da memória em Drummond (que é mais do que um simples "tema") não se restringe à experiência familiar ou itabirana do eu lírico, ao contrário: poemas fundamentais n’ A rosa do povo, como "Resíduo", "Indicações" e "Versos à boca da noite", são imprescindíveis para a problemática da memória, em especial porque explicitam
} 
constam da Antologia, e não apenas uma: " $\mathrm{D}=$ dramático (“Ato”)", além de "F= fechamento do discurso" 30 .

Drummond havia proposto a seção "Uma, duas argolinhas” (ou “exercícios lúdicos”) em separado de "Poesia contemplada” (ou “A própria poesia”), o que parece sugerir que a linguagem receba tratamento diferenciado num grupo e noutro; no primeiro grupo, o trabalho com a linguagem explicitaria a inventividade, enquanto no segundo grupo a "tônica” estaria na reflexão “temática”, e não apenas formal, sobre o trabalho poético. Em princípio, o "bloco do fechamento do discurso” que Iumna Simon propõe parece se aproximar dos “exercícios lúdicos”.

Do ponto de vista do programa, todavia, manifesta-se a consciência plena da tarefa que cabe ao poeta desempenhar. Antes de procurar efetivar a comunicação com os demais homens, é preciso salvar as palavras das amarras petrificantes impostas pelos condicionamentos histórico-sociais. E, se a proposta radical de "Procura da Poesia" visa à comunicação de novas formas, e não de conteúdos, se objetiva levar às últimas conseqüências a exploração da palavra em si mesma, enquanto objeto e valor autônomo, enquanto possibilidade infinita de invenção, não o faz como mero exercício lúdico em busca de originalidade. "Fá-lo por consciência de uma responsabilidade. Responsabilidade total, aceita como missão última do poeta perante a própria poesia como perante a vida da linguagem". ${ }^{31}$

Segundo Iumna Simon, o "fechamento do discurso" se configura quando a "função poética” (conceito tomado à teoria de Roman Jakobson) predomina sobre as outras “funções” (“emotiva”, “referencial”, “conativa”, entre outras).

Quando tratamos da abertura do discurso poético à comunicação e revelação do mundo, insistimos nos procedimentos sintáticos caracterizadores da ampliação da frase - a hipotaxe, a aposição, o vocativo, as acumulações ou sinonímias coordenantes, as reduções, entre outros - com o intuito de demonstrar a abertura semântica da mensagem poética. Ou seja, de verificar que a "função poética" sofre uma perda considerável em favor do aumento da "informação semântica". Isto porque, impõe-se como "dominante" do sistema poético o fator novo da comunicação, determinando o desenvolvimento do discurso pela introdução de explicações detalhadas - o discurso avança $e$

formalmente o quanto a memória é uma construção situada no presente, mais que simples evocação do passado. No entanto, Iumna os reúne na categoria "I= indivíduo" (correspondente a "Um eu todoretorcido"). Esta escolha parte de um conceito do que é "memória" que não dá conta de entender a dimensão temporal complexa da poesia do "tempo presente" drummondiana.

30 "Ato" é o título da terceira seção de Lição de coisas, da qual constam os poemas: "O padre, a moça", "Os dois vigários", "Massacre" e "Remate". O livro foi publicado em 1962.

${ }^{31}$ SIMON, op. cit., p. 168. O texto que a autora cita está em Augusto de CAMPOS, Teoria da poesia concreta, p. 112. 
aproxima-se da prosa no sentido de atingir mais diretamente o receptor da mensagem.

Neste capítulo ["Capítulo II - "A procura da poesia: o fechamento do discurso poético”, cuja epígrafe são os versos 12-14 de “Áporo”], trataremos particularmente da introdução do desvio no sistema, isto é, da ruptura com a "dominante". Assim sendo, insistiremos agora em procedimentos poéticos diametralmente opostos àqueles - a síntese, a elipse, as equivalências, a ruptura com a linearidade discursiva, os cortes rítmico-espaciais - a fim de demonstrar a direção especificamente poética da mensagem. Isto é: examinaremos o fechamento do discurso pela supremacia da "função poética": a configuração icônica da mensagem, "a mensagem enquanto tal" [a autora cita Roman Jakobson, Essais de linguistique génerale, p. 18]. Grau máximo de "informação estética" enquanto recurso à "imprevisibilidade, à surpresa, à improbabilidade da ordenação dos signos" [a autora cita a observação de Haroldo de Campos a respeito de Max Bense em Metalinguagem, p. 22].

Os poemas de A rosa do povo que constam de "Uma, duas argolinhas" são "O mito” e "Caso do vestido”, que Iumna Simon agrupa em “A= amor ('amar-amaro”)”. Os únicos dois poemas reunidos por Simon no suposto "bloco do fechamento" e que constam da Antologia são “Áporo” e "Vida menor”, que o poeta, diferentemente de Simon, reúne respectivamente em "Na praça de convites" e em "Tentativa de exploração e de interpretação do estar-no-mundo”.

Neste trabalho, daremos especial atenção à análise dos conjuntos E ["engajamento"] e F ["fechamento do discurso"], que atualizam e ilustram, no nível da própria composição da obra, a contradição fundamental do signo poético entre autonomia e comunicação. A fim de analisarmos as oposições entre tais conjuntos, tomaremos como ponto de referência a operação metalingüística que percorre todo o livro. Quanto aos demais poemas, serão considerados em relação a esses dois grupos, uma vez que atualizam as tensões geradas pela antinomia básica. ${ }^{33}$

Segundo a autora, o "bloco do fechamento” é composto pelos poemas: “Áporo”, “Ontem”, “Fragilidade”, “O poeta escolhe o seu túmulo”, "Vida menor”, “Campo, chinês e sono”, “Episódio”, “Nova canção do exílio”, "Economia dos mares terrestres” e "Equívoco", todos consecutivos na disposição do livro. (Haveria um último poema, não pertencente ao "bloco", em que também predominaria o "fechamento" como tônica: “Edifício São Borja”). A este "bloco”, cuja “dominante” (ou "tônica”) seria a "função poética”, a autora opõe o "bloco do engajamento” (identificado como “Na praça dos convites”), composto pelos consecutivos “Notícias”, “América”, “Cidade prevista”,

${ }^{32}$ Idem, ibidem, p. 171.

${ }^{33}$ Idem, ibidem., p. 61, grifo nosso. 
“Carta a Stalingrado”, “Telegrama de Moscou”, “Mas viveremos”, “Visão 1944” e “Com o russo em Berlim” (a chamada "lírica de guerra”). (Sob a suposta "abertura do discurso à comunicação”, haveria também os dispersos “O medo”, “Nosso tempo”, “Anúncio da rosa”, “O elefante” e "Morte do leiteiro”). Um bloco seria antinômico em relação ao outro, antinomia essa que explicaria o dinamismo de toda a coletânea, e que resultaria intensa, entre outros fatores, graças à disposição consecutiva na obra. Desse conflito dual entre abertura e fechamento do discurso à comunicação, resultaria, para Simon, a diversidade temático-formal da coletânea.

... A Rosa do Povo representa, como ensaiamos demonstrar, o momento das grandes tensões da trajetória do poeta: ao mesmo tempo que continua a linha de experimentações praticada nos livros anteriores, abre-se ao fator novo da comunicação, instaura a ruptura com esse fator pela radicalidade da proposta de "Procura da Poesia" e antecipa, porque já contém, como reflexão e prática, os procedimentos das fases posteriores. Disso tudo resultam a riqueza e a variabilidade dos procedimentos temático-formais praticados nas cinqüenta e cinco peças constituintes do conjunto. ${ }^{34}$

O poema “Áporo” é central para a análise de Simon. A "Primeira parte” do trabalho, que discute a "abertura” do discurso poético ao "fator novo da comunicação", termina com o capítulo III - “As aporias da participação”. A “Segunda parte”, toda ela, organiza-se sobre a idéia de “aporia”: o Capítulo I chama-se “Da 'rosa do povo’ à ‘orquídea antieuclidiana'” (“áporo” é o nome de um inseto e é também o nome de uma orquídea, e justamente sobre essa polissemia é que o poema desenvolve-se; trata-se da narrativa de um inseto escavador que se transfigura numa orquídea); o Capítulo II servese da leitura analítica do poema “Áporo”, para entender os recursos poéticos que servem ao predomínio da "função poética”, como contraponto ao discurso engajado, “prosaico”. A questão que se coloca é que Drummond insere “Áporo” na seção “Na praça de convites” (ou “O choque social”), em sua Antologia: justamente a seção que Simon identifica como o suposto bloco antinômico do " $E=$ engajamento", a que o poema “Áporo” supostamente se opõe.

\footnotetext{
${ }^{34}$ Idem, ibidem, p. 201.
} 
Há outras discordâncias entre a classificação do poeta e a da autora. Iumna Simon reúne "Nosso tempo”, “Anúncio da rosa”, “O elefante” e “Morte do leiteiro” em “E= engajamento ('na praça de convites')”, enquanto Drummond os agrupa em “Amaramaro” (ou “O conhecimento amoroso”). Para Simon, “Rola mundo”, “Resíduo” e "Movimento da espada” pertencem a "I= indivíduo ('um eu todo-retorcido')”; para Drummond, pertencem a "Tentativa de exploração e de interpretação do estar-nomundo” (ou "Uma visão, ou tentativa de, da existência”). “Consolo na praia” cabe em “M= memória ('família, 'terra natal’)”, segundo Simon; Drummond o reúne em “Um eu todo-retorcido” (ou “O indivíduo”). Quanto a “O mito”, “Caso do vestido”, “Áporo” e "Vida menor”, as discordâncias já foram apontadas. (A discussão sobre “Áporo” faz-se especialmente importante para a problemática do nosso estudo).

Quanto aos poemas "Procura da poesia”, “A flor e a náusea”, "Retrato de família”, “Idade madura”, "Versos à boca da noite”, “Indicações”, “Os últimos dias”, "Mário de Andrade desce aos infernos" e "Canto ao homem do povo Charlie Chaplin”, tanto Iumna Simon como Drummond os agrupam em categorias correspondentes.

Sendo assim, há discordância (involuntária) em relação a onze poemas, e concordância em relação a nove. Os trinta e cinco outros poemas de A rosa do povo não constam da Antologia poética, de modo que a reunião nas categorias propostas por Simon não podem ser comparadas com as do poeta.

Como o próprio Drummond observara, é perfeitamente possível que os poemas pertençam a mais de um grupo "temático", por isso não haveria nenhuma incoerência nos estudos críticos que apreciassem a tônica dos poemas diferentemente do próprio poeta. Segundo Antonio Candido, a poética drummondiana, entre 1935 e 1959, gira em torno das "inquietudes", o que faz com que os temas interpenetrem-se mesmo quando aparentemente contraditórios, e resolvam-se no plano da expressão, onde se efetua a síntese das tensões, sempre decorrentes duma subjetividade hipertrofiada; não se trata duma poética de temas, assuntos ou formas, mas duma multiplicidade cuja coerência está no núcleo das “inquietudes”.

Levando em conta que parte da recepção à poesia drummondiana demonstrou-se maniqueísta ao estabelecer uma poesia “participante” em separado de uma poesia mais inventiva ou então mais subjetiva, louvando uma em detrimento da outra ${ }^{35}$, e

${ }^{35}$ Sérgio Buarque de Holanda escreveu, um ano após a publicação de Claro enigma por Drummond, como resposta aos equívocos da recepção crítica ao livro: 
considerando que uma tal recepção não foi capaz de alcançar a integridade na multiplicidade da obra drummondiana, é possível propor que a estrutura da Antologia de 1962 procure antes sublinhar o dinamismo da poética processual que reforçar abordagens temático-formais. Isso explicaria a reunião de "Elegia 1938”, poema profundamente engajado de Sentimento do mundo, em "Amar-amaro" (ou "O conhecimento amoroso”) ${ }^{36}$, ato a princípio incompreensível, senão no sentido de que o impulso em direção ao encontro do outro e do mundo (o "sentimento do mundo") é uma forma de "eros". Mas como entender os versos finais em termos de "eros", e não de "tanathos”?

19. Aceitas a chuva, a guerra, o desemprego e a injusta distribuição

20. porque não podes, sozinho, dinamitar a ilha de Manhattan.

Drummond espalha poemas claramente engajados por diversas seções. "A flor e a náusea” encontra-se em "Um eu todo-retorcido”. "Canto ao homem do povo Charlie Chaplin” está em “Cantar de amigos”. “Morte do leiteiro” está em “Amar-amaro”. “O mito" está em "Uma, duas argolinhas". "Movimento da espada” encontra-se em “Tentativa de exploração e de interpretação do estar-no-mundo”. Todos poderiam perfeitamente reunir-se em "Na praça de convites”, onde se encontra, por exemplo, “Áporo”, cujo engajamento não é evidente, e só se pode alcançar quando se tem em vista o contexto de produção e de publicação do poema. Com a disposição dos poemas em seções de sua Antologia, Drummond parece evidenciar a complexidade de sua obra, porque, em vez de estabelecer compartimentos estanques, antes sublinha o dinamismo e o caráter dialogal que há entre os textos, tornando vazios os rótulos de "poesia social”

"A poesia atual nasceu de uma fadiga da sensibilidade. Durante longo tempo, e especialmente durante o século romântico, valeram-se os autores, até à usura, de palavras, de epítetos, de imagens, de cadências, que tinham como alvo, deliberado ou não, atribuir à linguagem poética uma dignidade inconfundível. Houve momento, porém, em que se evidenciou cabalmente o fatal desgaste desses instrumentos.

Duas soluções, aos poucos, se foram apresentando aos inconformados. Uma, a solução aristocrática e idealista, consiste, como queria Mallarmé, em emprestar-se a uma inflexão mais pura às palavras da tribo. Liberta das suas vestimentas e decorações habituais, a expressão parecia destacar-se, agora, do contingente e do profano, para alcançar páramos só raramente acessíveis a qualquer voz humana.

A outra solução, sem dúvida mais radical, busca, ao contrário, retirar a poesia de seu esplêndido isolamento a fim de deixar que nela circule livremente o ar da rua. (...)

Seria engano, no entanto, julgar-se que, tendo raízes comuns, as duas soluções, na aparência adversas entre si, e que se poderiam chamar respectivamente a "hierática" e a "demótica", se destinem a viver sempre separadas. Precisamente a obra de Carlos Drummond de Andrade é, toda ela, um exemplo de sua feliz convivência e conjugação." ("Rebelião e convenção". in: Sônia BRAYNER (org.), Carlos Drummond de Andrade, p. 188-189).

${ }^{36}$ Carlos DRUMMOND DE ANDRADE, Antologia poética, p. 97-98. 
ou “experimental”37. Na seção “Uma, duas argolinhas” (ou “exercícios lúdicos”), encontram-se “O mito” e "O caso do vestido”, em que a inventividade está presente como de resto em toda a obra de Drummond -, mas que certamente apresentam outros aspectos em maior relevo.

O fato de Iumna Simon adotar o mesmo critério de agrupamento dos poemas que o poeta, segundo a "tônica da composição", e discordar do poeta quanto à classificação de diversos poemas demonstra a proposição de Antonio Candido em relação à obra drummondiana de que a riqueza de temas faz com que todos se cruzem e interpenetrem, de modo que a amplitude temática deriva das “inquietudes”, e a coerência entre os poemas está, não no assunto, mas no núcleo subjetivo de que derivam tanto os poemas considerados sociais quanto os poemas mais individuais, todos eles tendo como denominador comum a preocupação expressiva.

\footnotetext{
${ }^{37} \mathrm{Na}$ Antologia poética, a "Nota da Primeira Edição" (p. 7), anteriormente reproduzida, qualifica e ordena numericamente as nove seções propostas pelo poeta, mas a ordem dessa enumeração não corresponde à disposição efetiva das seções ao longo da obra. Entretanto, essa mesma ordenação de 1 a 9 que a "Nota" propõe, caso reaparecesse no "Sumário", seria refeita nos seguintes termos: 1, 2, 3, 4, 6, 8, 7, 5, 9. Num poeta obsessivo com o rigor arquivístico como Drummond, isso não parece soar como descuido ou irrelevância, mas como indicação do caráter analógico da sua obra, a que não se aplicam definitivamente categorias como "poesia social" em contraponto à "poesia inventiva". As seções propostas ressaltam a organicidade da obra, em vez de estabelecer uma categorização estanque. Ademais, como o próprio poeta deixa claro na "Nota", trata-se de "uma Antologia que não segue a divisão por livros nem obedece a cronologia rigorosa. O texto foi distribuído em nove seções, cada uma contendo material extraído de diferentes obras, e disposto segundo uma ordem interna." Quando Drummond acrescenta que "A razão da escolha está na tônica da composição, ou no engano do autor. De qualquer modo, é uma arrumação, ou pretende ser.”, o chiste, antes de exercer uma função meramente retórica, deixa claro que a obra, multifacetada, permite diversas abordagens, o que obriga o leitor a situar-se ativamente no entendimento e na experiência da obra, que se quer aberta.
} 
CAPÍTULO 1

CONSIDERAÇÃO 


\section{CAPÍTULO 1 - Consideração}

\section{CONSIDERAÇÃO DO POEMA}

1. Não rimarei a palavra sono

2. com a incorrespondente palavra outono.

3. Rimarei com a palavra carne

4. ou qualquer outra, que todas me convém.

5. As palavras não nascem amarradas,

6. elas saltam, se beijam, se dissolvem,

7. no céu livre por vezes um desenho,

8. são puras, largas, autênticas, indevassáveis.

9. Uma pedra no meio do caminho

10. ou apenas um rastro, não importa.

11. Estes poetas são meus. De todo o orgulho,

12. de toda precisão se incorporaram

13. ao fatal meu lado esquerdo. Furto a Vinícius

14. sua mais límpida elegia. Bebo em Murilo.

15. Que Neruda me dê sua gravata

16. chamejante. Me perco em Apollinaire. Adeus, Maiakóvski.

17. São todos meus irmãos, não são jornais

18. nem deslizar de lancha entre camélias:

19. é toda a minha vida que joguei.

20. Estes poemas são meus. É minha terra

21. e é ainda mais do que ela. É qualquer homem

22. ao meio-dia em qualquer praça. É a lanterna

23. em qualquer estalagem, se ainda as há.

24. - Há mortos? há mercados? há doenças?

25. É tudo meu. Ser explosivo, sem fronteiras,

26. por que falsa mesquinhez me rasgaria?

27. Que se depositem os beijos na face branca, nas principiantes rugas.

28. O beijo ainda é um sinal, perdido embora,

29. da ausência de comércio,

30. boiando em tempos sujos. 
31. Poeta do finito e da matéria,

32. cantor sem piedade, sim, sem frágeis lágrimas,

33. boca tão seca, mas ardor tão casto.

34. Dar tudo pela presença dos longínquos,

35. sentir que há ecos, poucos, mas cristal,

36. não rocha apenas, peixes circulando

37. sob o navio que leva esta mensagem,

38. e aves de bico longo conferindo

39. sua derrota, e dois ou três faróis,

40. últimos! esperança do mar negro.

41. Essa viagem é mortal, e começá-la.

42. Saber que há tudo. E mover-se em meio

43. a milhões e milhões de formas raras,

44. secretas, duras. Eis aí meu canto.

45. Ele é tão baixo que sequer o escuta

46. ouvido rente ao chão. Mas é tão alto

47. que as pedras o absorvem. Está na mesa

48. aberta em livros, cartas e remédios.

49. Na parede infiltrou-se. O bonde, a rua,

50. o uniforme do colégio se transformam,

51. são ondas de carinho te envolvendo.

52. Como fugir ao mínimo objeto

53. ou recusar-se ao grande? Os temas passam,

54. eu sei que passarão, mas tu resistes,

55. e cresces como fogo, como casa,

56. como orvalho entre dedos,

57. na grama, que repousam.

58. Já agora te sigo a toda a parte,

59. e te desejo e te perco, estou completo,

60. me destino, me faço tão sublime,

61. tão natural e cheio de segredos,

62. tão firme, tão fiel... Tal uma lâmina,

63. o povo, meu poema, te atravessa. 
As características da poética drummondiana, em A rosa do povo, vêm expressas já no primeiro poema da coletânea (“Consideração do poema”), cuja coerência, paradoxalmente, resulta da multiplicação vertiginosa dos problemas, das perspectivas e dos recursos lingüísticos, sendo que estes aspectos diversos entrecruzam-se e contaminam-se. Dito de outra maneira, a unidade do poema resulta da fragmentação temático-formal. É possível extrair uma gama infinita de significados deste poema, porque o sistema simbólico construído é de uma complexidade inesgotável.

Abordá-lo segundo aspectos exclusivamente semânticos torna-se redutor porque o tema é a própria transfiguração dos significados, entendida nas múltiplas conexões que o complexo campo do discurso poético permite estabelecerem-se entre o significante e o significado. Não se entenda, por simples oposição a isso, que o poema deva ser abordado exclusivamente pelo nível significante, porque a riqueza de recursos poéticos procura plasmar o problema conceitual da significação como ato integrativo. Privilegiar os campos da forma ou do conteúdo não permite a compreensão adequada do poema, porque a sua proposta é integrativa.

Do ponto de vista formal, é muito difícil identificar em que consiste a coerência deste poema, uma vez que ele se serve de recursos expressivos tão variados e aparentemente tão desconexos. Ao “considerar o poema”, o eu lírico traça um retrato multifacetado do ato poético. Cada face do retrato justapõe-se às demais, de modo que os diversos fragmentos terminam por compor um todo. Na verdade, a aparência fragmentária resulta do conceito de que o trabalho artístico deve pressupor posturas ativas e criativas. A perspectiva lírica faz encontrarem-se as dimensões da autoria, da leitura e da própria obra (processo de construção de significados) no lugar de sujeitos do discurso (objetos do retrato poético). O princípio constitutivo desse encontro complexo entre as pessoas do discurso e os recursos lingüísticos são as práticas analógicas da figuração metonímica. 
“Considerar” o poema não implica reiterar os significados convencionais, e sim restabelecer a organicidade dos significantes frente às necessidades concretas da vida. Não se trata, portanto, de recusar as múltiplas possibilidades que os significantes podem adquirir na esfera cotidiana ${ }^{38}$. Se o cotidiano alienante das práticas sociais capitalistas busca separar os significantes dos significados para que estes surjam como algo em si, ocultando-se assim as relações orgânicas entre significante e significado na produção de sentido, a adoção dicotômica de um dos pólos do processo consistiria na confirmação do fetiche, tanto faz se de modo afirmativo (“abertura do discurso à comunicação”) ou negativo (“fechamento do discurso sobre si próprio”). O poema, ao contrário, coloca em diálogo a esfera da significação (plano simbólico em que a vida social se reproduz) e a esfera da vida material (plano concreto em que a vida social se produz). Por isso, ao discutir o processo de significação, trata-o metalingüisticamente (como tema e como forma) e insere essa metalinguagem no campo semântico cotidiano. Mas esse campo semântico não tem significação unívoca no poema: remete à temporalidade em que os sentidos dos gestos e dos símbolos são tácitos, mas remete também às práticas concretas ou simbólicas que, em não atendendo às necessidades vitais, podem ser ressignificadas.

O cotidiano é a temporalidade da vida social em que a produção e a reprodução da vida material encontram-se. Separar a produção de sentido das demais esferas da produção da existência é um ato reificante, que o engajamento poético drummondiano enuncia e denuncia. O movimento lingüístico não está completo no ato de desfigurar os sentidos convencionais, mas no movimento complementar de atribuir aos mesmos significantes outros possíveis significados, diante das necessidades reais (concretas ou simbólicas). É por isso que os processos analógicos conferem coerência aos diversos recursos, tanto os temáticos quanto os formais, vistos da microperspectiva (em que a parte evoca o todo) ou da macroperspectiva (em que o todo se compõe de partes). Forma e conteúdo, significante e significado são momentos que se denotam fragmentariamente, mas que no processo de conotação se integram. Explicitar a fragmentação é um recurso temático-formal importante, porque denuncia a reificação.

\footnotetext{
38 A problematização do conceito de "cotidiano", aqui, remete a Henri LEFEBVRE (in La vida cotidiana en el mundo moderno). Para o autor, o cotidiano é a temporalidade em que é possível perceber a intersecção entre os aspectos materiais e os aspectos simbólicos da vida social, integrados de maneira a permitir a satisfação das necessidades humanas. Por esse motivo, é o espaço privilegiado para a superação da dicotomia entre o concreto e o simbólico, que vigorou no campo filosófico até às propostas do pensamento marxista. Lefebvre defende que as ciências humanas convirjam no estudo dos fenômenos cotidianos para que, dessa forma, consigam desvelar a separação reificante, no mundo técnico-científico, operada pelos interesses do capital. Assim sendo, o conceito de "cotidiano", segundo Lefebvre, não remete às práticas rotineiras, desprovidas de sentido, quando, ao contrário, se trata do campo em que as significações se produzem e reproduzem e, portanto, é altamente "significativo".
} 
Realizar, na complexidade da prática lingüística, a integração desses recursos é uma forma de superar a reificação (separação das esferas do simbólico e do concreto).

Os sujeitos do discurso (autor, público e obra) vivenciam os movimentos opostos e complementares (fragmentação/ integração) no ato complexo do discurso lingüístico. Supera-se, assim, a reificação. A linguagem integra, como experiência, o processo de produção de sentidos. A significação, que é o trânsito orgânico entre significante e significado, transfigura-se como parte de um todo maior, que é a produção e a reprodução da existência. O tipo de pensamento poético para tanto é analógico, e sua coerência está nas operações metonímicas.

Na primeira estrofe, há um processo de aparência lógico-discursiva em que se sugere uma análise da linguagem poética por meio de considerações sobre a "rima" (note-se que o campo semântico nuclear do termo “consideração”, já proposto no título, remete à atividade intelectiva). A preocupação com a escolha lexical organiza aspectos semânticos e fônicos, e organiza também o plano do verso (metro e ritmo), segundo uma intenção expressiva conceitual que se explicita. Trata-se dum processo analítico que evidencia os recursos poéticos, reduzindo-os a fragmentos, a unidades expressivas. Em síntese, a intenção conceitual figura a expressão poética como trabalho.

A força do problema semântico organiza o plano sintático de maneira a transcender o verso como unidade de significação. Parece que o discurso, em tom declarativo, visa à informação semântica, e por isso a frase amplia-se para além da unidade do verso, o que se sublinha pela conjunção explicativa ("que todas me convêm”), a concluir uma longa construção sintática, que se iniciara no primeiro verso em torno do termo regente (“a palavra sono”) e que estabelecera, seguindo o campo semântico do léxico "rimarei”, relações entre aquele termo inicial e os termos regidos (“a incorrespondente palavra outono”, “a palavra carne”, “qualquer outra”), através de reiterar-se o termo de relação “com” (significativamente elíptico no quarto verso, quando a "rima” deixa de obedecer ao campo sonoro de "sono" e se submete ao campo semântico de “carne”). 
Por esse alongamento da frase, o tom do poema parece aproximar-se da "prosa", isto é, dum discurso em que a idéia preside a organização dos elementos lingüísticos, visando antes à clareza das proposições e do pensamento que à própria mensagem.

A aparência de "prosa” decorreria não apenas da sintaxe, mas também do sentido corrente que as escolhas lexicais atribuem ao campo semântico. "Sono" aproxima o seu sentido de “carne” e não de “outono”, recusando assim a semelhança fônica como recurso significante, de caráter mais ornamental que conceitual. A "materialidade" de "carne” parece reforçar o significado cotidiano de "sono" (no sentido de recuperação das forças psicofísicas).

O caráter intencional dessas escolhas artísticas sublinha-se, na medida em que "sono" e “outono" de fato configurariam uma rima consoante, uma vez que, mais do que homofônicos, situam-se no fim de dois versos próximos. Entretanto, a diferença dos metros e dos ritmos esvazia a expressividade do potencial rímico, que resulta caricatural. Os esquemas métricos e rítmicos dos dois versos variam (v. 1: eneassílabo, 1-4-7-9; v. 2: dodecassílabo, 1-3-7-10-12); a “incorrespondência” métrica e rítmica termina por se sobrepor à homofonia. A proposição semântica do enunciado valoriza a expressividade do metro e do ritmo, esvaziando o potencial expressivo da homofonia em fim de versos.

Do ponto de vista sintático, os dois primeiros versos formam um período, porém incompleto. O termo regente do primeiro verso (“a palavra sono”) estabelece relação negativa com o termo regido do segundo verso (“incorrespondente palavra outono"), conferindo uma identidade provisória ao período. Essa identidade é provisória porque pede desdobramento sintático nos dois próximos versos, e porque se assenta na negatividade do "não” (primeira palavra do primeiro verso).

A brutalidade desta negativa desdobra-se no importante e anteposto qualificativo do termo regido (“incorrespondente”). Trata-se dum vocábulo formado por vogais fechadas (as três nasais intensificam o aspecto oclusivo das três outras), que se associam a consoantes predominantemente explosivas, reforçando-se o efeito de aversão ao encontro. Trata-se, ademais, dum vocábulo longo e com função central no verso de que participa (o qual é “incorrespondente” em relação ao anterior, em termos métricos e rítmicos).

A sintaxe do terceiro e do quarto versos é um desdobramento da intenção "rímica” enunciada negativamente antes, mas que agora se enuncia de modo afirmativo. O enunciado novamente sugere um paradoxo, porque a sonoridade do termo regente ("a 
palavra sono”) não parece corresponder à sonoridade do termo regido ("a palavra carne”). É de se notar, entretanto, que a claridade do triplo /a/, comum aos dois termos reiterados ("palavra” / "palavra”), se transfere à tonicidade de “carne”, o que torna a “incorrespondência” sonora algo relativo. Nota-se, também, que ambos os versos (1 e 3) são eneassílabos, e os termos regente e regido encontram-se em situação de acoplamento, isto é, as suas posições rítmicas e sintáticas, paradigmaticamente coincidentes, parecem concorrer para a equivalência semântica ${ }^{39}$.

Ao fim de todas essas relações complexas, a experiência da irregularidade tornase mais expressiva que as equivalências possíveis. Do ponto de vista do verso, é possível dividir os movimentos de negação e de afirmação em dois grupos simétricos: os dois primeiros versos negam, enquanto os dois posteriores afirmam. Mas aqui, novamente, entra o papel decisivo da métrica e da rítmica para decidir em favor da irregularidade e da fragmentação. Vimos que o terceiro verso, que enuncia a "rima" entre "sono” e “carne”, tem a mesma métrica que o primeiro (é igualmente eneassílabo). Há estruturas sintagmáticas não apenas paralelas (porque situam-se no fim de versos de mesmo metro), mas léxica e ritmicamente reiteradas (no primeiro verso, “a palavra sono”; no terceiro verso, “a palavra carne”). Porém, ambos os esquemas rítmicos diferem (1-4-7-9 no primeiro, 3-7-9 no segundo), em consonância com a diferença tonal (embora o tom seja declarativo em ambos, no primeiro par de versos, ele é negativo, enquanto no segundo par, ele se torna afirmativo). E é o tom dissonante que sobrepõe a discordância sintagmática ao pseudoparalelismo paradigmático.

O verso 4 conclui esse processo em que o sujeito lírico explicita os recursos micropoéticos da “rima” (metonímia de “poesia”) de maneira aparentemente lógicoanalítica. A escolha do vocábulo apropriado para o objetivo "rímico” parece esclarecer o seu critério de pertinência. Se “qualquer outra” e "todas” podem estabelecer relação com "sono", segundo as necessidades expressivas do sujeito lírico, então não deve haver hierarquia nem convenção apriorísticas. Isto não significa a recusa (ou a escolha) do significado em favor (ou em detrimento) do processo significante, e sim que o processo significante abandone as estruturas pré-estabelecidas para propiciar relações orgânicas e, portanto, significados libertários. O sujeito lírico relaciona "sono” com “carne” para que o denominador comum seja o processo vital na sua inteireza; o sujeito não o

\footnotetext{
${ }^{39}$ Samuel R. LEVIN, Estruturas lingüisticas em poesia.
} 
relaciona com "outono" porque a mera homofonia em fins de verso tem como denominador comum o ornamento e a convenção.

É de liberdade que se trata. A liberdade não pressupõe intransitividade; ao contrário: o entendimento analítico das ferramentas lingüísticas propicia a denúncia das estruturas reificadas. A denúncia do mecanismo visa à refeitura do processo. Insista-se em que é de relação, ou de trânsito, que se trata. "Rimar", na sua acepção afirmativa, tem sentido relacional. Neste processo, constroem-se identidades e alteridades: entre a negação e a afirmação; entre o termo regente e os termos regidos; entre a correspondência (simetria) e a incorrespondência (disritmia); entre o sintagma e o paradigma; entre o fragmento e a unidade. Essa construção é profundamente dialogal. Não há liberdade nos significados prévios, assim como não há liberdade na significação como estrutura, porque ambos os pólos não possuem existência em si. Não existem mecanismos de linguagem. A linguagem é um campo orgânico, regido pela volição (pelo desejo e pela necessidade: impulsos relacionais).

É esse o sentido conclusivo que o quarto verso sugere, sob a aparência de discurso “prosaico”. Às definições de “prosaico" anteriores (quando o sentido preside a construção formal, ampliando-se a sintaxe com ganho em informação semântica), acrescentem-se as marcas de oralidade. O vocábulo "que”, com sentido explicativo, a coordenar os períodos, e as repetições sintáticas e vocabulares (“rimarei”, “com” e “palavra”) imprimem ao poema uma oralidade que vem a se confirmar nas estrofes seguintes, sobretudo na aparência fragmentária e desconexa do pensamento, típica de situações de fala.

O jogo entre fragmentação e unidade que identificara os quatro primeiros versos, divisíveis em dois subgrupos menores (do ponto de vista do tom), que, por sua vez, subdividem-se e reagrupam-se segundo critérios diversos (métrica, ritmo, sonoridade, sintaxe, semântica), continua pelos quatro versos seguintes dessa primeira estrofe, em que o tom declarativo dá lugar ao tom descritivo. Novamente, o movimento principia negativo, mas esse movimento restringe-se ao verso inicial, para tornar-se afirmativo nos três últimos. Diferentemente dos quatro primeiros versos, esses quatro últimos formam um só longo período.

O campo semântico confirma a organicidade da linguagem, na medida em que as “palavras” acabam personificando uma série de atributos vitais do homem ("nascer”, “beijar-se”). Os versos 6 a 8 ilustram a proposição do verso inicial, onde a antecipação do sujeito vem reforçar o caráter de volição do ato criativo, em resposta à reificação das 
estruturas e do mecanicismo convencionais. Essas ilustrações secundam o campo semântico libertário não apenas imageticamente, mas também mobilizando o recurso sintático da enumeração. Os versos 6 e 8 enumeram, respectivamente, ações e atributos, não de maneira hierarquizante, mas de maneira anárquica, o que se confirma pela sintaxe inusitada do verso 7, por eles compreendido (enquanto este verso comporta a elipse do verbo numa oração fluente, aqueles outros entrecortam-se por vírgulas, em estruturas respectivamente ternária e quaternária). Todos esses recursos criam uma impressão muito forte de liberdade, o que confirma, formalmente, o que o enunciado propusera.

Nota-se, então, que os termos fundamentais para a problemática que regem a construção do poema são “rima” e "palavra”, que constituem figuras metonímicas, porque evocam um universo maior do que o seu significado imediato. É mesmo de homofonia em fins de verso (recusada) e é mesmo de unidades conceituais maiores do que o verso que se trata, muito embora essas práticas evoquem o universo simbólico mais amplo em que o trabalho poético se configura. Ao enunciar essas práticas rímicas e ao definir a natureza das palavras, a força do problema acaba por mobilizar uma série de componentes formais de maneira a explicitar o seu funcionamento. Há, portanto, um movimento analítico, em que as unidades expressivas são explicitadas minuciosamente, para evidenciar o trabalho poético, representado por metonímia.

A força da problemática artística sobrepõe-se como conceito poético à forma, de modo que os recursos de linguagem servem à volição, e não o contrário. O trabalho poético explicita-se como se os andaimes da criação se expusessem, numa recusa da ornamentação que os planos denotativo e conotativo sublinham, quando se entrelaçam na construção complexa e conjunta dos sentidos. Quando se denota a negação da rima, o plano sonoro sugere a homofonia, mas os planos métrico-rítmicos antecipam-se e assumem o comando da expressividade, em reforço ao enunciado. Dessa forma, por predominar a informação semântica sobre os demais planos do discurso, que se explicitam como unidades, o tom do texto assume um aspecto lógico-discursivo. Mas é aí que reside a "poeticidade” do discurso: porque se trata de representação.

Os vocábulos “rimar” e "palavras” explicitam-se como metonímicos desde o plano semântico. Estes sentidos metonímicos não são, em si, “literários”, porque já a linguagem corrente os emprega como sinônimos de ato poético e de linguagem verbal, respectivamente; por isso, perdem o efeito figurativo, deixam de efetuar uma transposição de sentidos, porque carregam um sentido tácito, pré-estabelecido. Quando 
o sujeito lírico rompe com o sentido convencional do que seja "rima" e figura a liberdade relacional que as "palavras" encerram, o significado restrito de "rima” ampliase para um todo mais amplo e de maior complexidade, que é a linguagem poética em sua organicidade, e o significado restrito de "palavra” liberta-se da fragmentação unívoca do sentido (“amarras”) e “dissolve-se” na polissemia. Assim, o fragmentário e intransitivo torna-se orgânico e integrativo. Quando a parte deixa de compor o todo como mecanismo, liberta-se da objetividade (“descoisifica-se”, “humaniza-se”), tornando-se um campo propício à volição, isto é, ao impulso do desejo e da necessidade, antes analógico (imagético) que lógico (discursivo).

Há movimentos contraditórios nessa estrofe: a convenção e o imprevisto, a fragmentação e a integração, o significante e o significado, as estruturas e a relação, a lógica e a analogia, a análise e a síntese. Não é possível estabelecer um jogo dicotômico entre esses contrários, porque a força do problema cria um movimento dialogal de tal modo que há entrecruzamento e contaminação, superando-se a antinomia e constituindo-se uma síntese.

A figuração do trabalho poético sob aparência lógico-analítica nomeia a “reificação”, um conceito abstrato, transformando-o em experiência estética. O trânsito do todo às partes, analítico, impregna-se da dimensão sensorial. A operação intelectiva figura o trabalho reificado, mas essa figuração, ao servir-se dos recursos poéticos, encaminha-se no sentido de integrar os recursos à construção de sentido, que resulta do desejo e da necessidade, e, portanto, humaniza, já que é ato volitivo. A volição marca o sujeito e imprime o desejo como impulso de encontro. O trânsito da objetividade à subjetividade pela escala lírica e cotidiana desfigura os mecanismos, transfigurando-os. Essas relações refeitas, orgânicas, permitem que as partes evoquem um todo liberto, não porque cessam as relações, mas porque elas se tornam um ato de vontade. O recurso poético para tanto é o pensamento metonímico, e a escala necessária é a do lirismo (lugar da radicalidade do sujeito) e a do cotidiano (em que se faz e refaz o trânsito do simbólico ao concreto). 
Na primeira estrofe, o movimento analítico é parte integrante do movimento maior na construção de sentido. Assim, o trabalho poético figura-se a partir de suas unidades, representando o plano do verso (sonoridade, metro, ritmo) como fragmentos, que se transfiguram por meio de imagens e figuras para atribuir à vontade lírica uma potência libertária, que preside a fatura. O trânsito analógico do todo às partes e da parte ao todo comporta a unidade conceitual, mas se faz, paradoxalmente, através de rupturas. O tom, por exemplo, sofre rupturas bruscas que, justapostas, configuram o processo metonímico de construção do sentido.

Este é o movimento em todo o poema. Na segunda estrofe, dá-se uma brusca mudança tonal. Antes, declarativo-descritivo ao figurar o microuniverso poético, agora, o tom do poema assume uma conotação autobiográfica, evocando portanto elementos exteriores ao texto. Os dois primeiros versos desta estrofe remetem imediatamente a “No meio do caminho", poema que consta da primeira coletânea de Drummond, de 1930 (Alguma poesia), publicado pela primeira vez na Revista de Antropofagia ${ }^{40}$, tendo como efeito "dividir no Brasil as pessoas em duas categorias mentais"41. O título do "poema da pedra" 42 incorpora-se ao verso como qualificativo posposto de "pedra" e anteposto de "apenas um rastro", de modo a situar-se "no meio do caminho" sintático do período nominal, exatamente como acontece no poema de 1928, e que não deixa de ser eco, igualmente, do movimento inicial da primeira estrofe, quando um período desdobrara-se, dificultoso, e terminara com a explicação coordenada de "que todas me convêm” (aqui, “não importa” é um desdobramento explicativo do período a que pertence).

Além da variação tonal brusca, o período que segue, embora seja conclusivo, apresenta-se semanticamente desconexo. Não se entende de que modo o termo "poetas" possa equivaler a "pedra” ou “rastro”, ou que relação estabelece com “palavras”, senão como metonímia das poéticas evocadas em seguida, personificadas nos nomes de seus

\footnotetext{
${ }^{40}$ Em julho de 1928.

41 A expressão é de Drummond e se encontra em "Autobiografia para uma revista", texto primeiramente publicado na Revista acadêmica e republicado no ano de 1944 em Confissões de Minas, p. 71-74.

42 Em 1967, por ocasião dos quarenta anos de publicação do poema, Drummond reuniu as mais diversas manifestações a respeito do poema, e publicou-as sob o título Uma pedra no meio do caminho. A apresentação desta antologia ficou a cargo de Arnaldo Saraiva, que, na p. 17, ressalta a intensificação dos ataques ao poema a partir dos anos 1940, quando passou a ser conhecido pela expressão "poema da pedra".
} 
autores - ou melhor, partes de nomes: prenomes ou sobrenomes ("Vinícius" [de Moraes], “Murilo” [Mendes], [Pablo] “Neruda”, [Guillaume] “Apollinaire”, [Vladimir] “Maiakovski”). Dessa maneira, a poética que o “poema da pedra” evoca se amplia, em círculos concêntricos, como símbolo de todo o movimento modernista brasileiro, que por sua vez encontra o meio literário latino-americano e toca a vanguarda européia, estendendo-se mesmo à literatura revolucionária russa.

Nota-se que esse processo fragmentário se serve, ao mesmo tempo, do termo "todo" (reiterado quatro vezes nessa estrofe, com variações de gênero e número) e do termo “incorporar" (no passado perfeito). A poética drummondiana enuncia a sua natureza dialética e relacional, evocando para si outros contextos lingüísticos, dentro do esforço de explicitar-se como trabalho e como lirismo.

Trata-se duma poética que, quanto mais subjetiva e pessoal se faz, mais realça o seu caráter coletivo, o que se percebe na figuração de "No meio do caminho": um poema fortemente emblemático, não apenas da obra drummondiana, como também de todo o Modernismo, e que, segundo o eu lírico, evoca relações literárias ainda mais amplas, ainda não esclarecidas pela fortuna crítica. De toda forma, se a primeira estrofe investira no universo micropoético, a segunda "salta” para o universo macropoético sem, por isso, abandonar o universo da linguagem. E insere, no universo do texto, a presença necessária do contexto.

Na primeira estrofe, a sincronia do universo microlingüístico pedia o presente do indicativo, numa descrição que atribuía ao universo metonímico da linguagem “em estado de dicionário"43 uma sensação temporal de liberdade (não como ausência absoluta de vínculos, mas como possibilidades relacionais múltiplas). Que a declaração inicial recorresse ao futuro do presente ("rimarei”), isto marcava mais ainda o universo relativamente sincrônico da linguagem: um presente que se refaz em toda a sua carga de novidade a cada leitura e releitura do poema. A segunda estrofe, no entanto, ao afirmar que “Estes poetas são meus.”, traz para a dimensão sincrônica do presente lingüístico a diacronia do contexto; no caso, o contexto lírico, que multiplica, no gauchismo do eu lírico, diversas experiências subjetivas.

\footnotetext{
${ }^{43}$ Referência ao $35^{\circ}$ verso de "Procura da poesia" ("Ei-los sós e mudos, em estado de dicionário.”), que será objeto de análise no próximo capítulo.
} 
O gauchismo é um recurso significativo da obra drummondiana ${ }^{44}$. Constitui a sua persona poética já na primeira estrofe do primeiro poema publicado em livro (“Poema de sete faces”, em Alguma poesia ${ }^{45}$ ).

1. Quando nasci, um anjo torto

2. desses que vivem na sombra

3. disse: Vai, Carlos! ser gauche na vida.

A palavra gauche significa esquerdo, malfeito, desastrado, errado. Na Poesia completa de Drummond, há um retrato do poeta pré-adolescente ${ }^{46}$; a legenda aponta: “1915. Carlos Drummond de Andrade (primeiro à esquerda), com seus pais e irmãos.” O contexto de Alguma poesia, segundo a fortuna crítica drummondiana e na concepção do próprio autor ${ }^{47}$, não é o de uma literatura engajada nas questões políticas, mas de uma postura individualista, preocupada em romper com as convenções literárias e com o pensamento conservador, sem a dimensão do "sentimento do mundo" - e, de fato, essa preocupação apenas se enuncia claramente no livro que recebe aquela expressão como título (Sentimento do mundo, publicado em 1940, seis anos após a sua mudança de Minas Gerais para a então capital do país, Rio de Janeiro ${ }^{48}$ ). A crer em que o contexto de Alguma poesia seja esse mesmo, o de preocupações estéticas desvinculadas da dimensão sócio-política (o que é questionável, porque a estética não se separa das demais dimensões do real, ainda mais em se tratando do movimento modernista), o significado de “gauche”, na poesia de 1930, representa, no mínimo, uma ironia com os

\footnotetext{
${ }^{44}$ Cf. Affonso Romano de SANT'ANNA, Drummond, o Gauche no tempo, e Alcides VILLAÇA, "Capítulo drummondiano", in Lendo poetas brasileiros.

${ }^{45}$ Carlos DRUMMOND DE ANDRADE, Poesia completa e prosa, p. 53.

46 Idem, ibidem, p. 44.

47 "Num esboço autobiográfico encomendado pela Revista Acadêmica, Drummond nos dá uma interpretação sucinta de sua evolução lírica até Sentimento do Mundo. Segundo ele, Alguma poesia traduz uma 'deleitação ingênua' no tocante ao indivíduo; em Brejo das Almas o individualismo se exacerba, mas ao mesmo tempo é submetido a uma visão crítica; enfim, Sentimento do Mundo resolve 'as contradições elementares' da sua poesia drummondiana. Como a lição dos textos tende a confirmar esta sintética exegese, não lhe acrescentaremos senão algumas advertências suplementares, visando a caracterizar a personalidade estilística do primeiro lirismo drummondiano (1925-1940).” José Guilherme MERQUIOR, Verso universo em Drummond, p. 47.

48 "Uma vez determinadas as raízes históricas e sociais da culpa, cumpre observar que ela só começa a despontar na lírica drummondiana a partir de 40, através das várias manifestações diretas e indiretas de que tratou Antonio Candido sob o rótulo de "inquietudes". Nem poderia ser de outro modo, pois é só nesse momento, com a transferência definitiva de Drummond para o Rio, o ingresso no funcionalismo público, as exigências de participação e posicionamento político-ideológico do artista e intelectual motivadas pela hora presente e a opção por uma poesia de inspiração social, que se pode dar o confronto aberto das posições contraditórias de que redunda a culpa em questão." Vagner CAMILO, Drummond: da Rosa do Povo à Rosa das Trevas, p. 243.
} 
símbolos duma elite que tinha em certos usos da cultura francesa uma expressão do seu poder oligárquico ${ }^{49}$.

O autor, ao representar a sua persona poética numa espécie de certidão de nascimento artístico como “esquerda”, e ao fazê-lo numa recusa irônica e ambígua da sua própria situação social de oligarca decadente (expressa no “idioma” da oligarquia em 1930), ao mesmo tempo que marca o lugar de onde fala, descentra-se de modo autoirônico e reflexivo ${ }^{50}$, isto é, coloca-se no centro da ação como quem espia a si mesmo e aos outros mas, ao fazê-lo, guarda certa distância de si, o que permite refletir sobre a sua situação no mundo ${ }^{51}$. Trata-se de um lirismo onde o lugar do eu está bem marcado, não apenas em termos de afeto, como também no sentido da reflexão, da intelecção; portanto, no sentido mais amplo de cognição. Por isso, a primeira pessoa do singular não se explicita em alguns poemas, empregando-se antes a terceira do singular, numa espécie de diálogo ${ }^{52}$, ou empregando-se o próprio nome do poeta (“Carlos”). Trata-se, também, de um recurso que muitas vezes expressa uma dor profunda, de modo mais eficaz que a simples confissão (esse recurso é particularmente importante em A rosa do povo).

Por tudo isso, a expressão “fatal meu lado esquerdo” traz uma densidade de significados em que a sincronia do poema se impregna da diacronia do contexto no seu mais amplo sentido: no sentido literário, no sentido autobiográfico e no sentido sóciopolítico. O primeiro poema de A rosa do povo evoca o primeiro poema de Alguma poesia (além de "No meio do caminho”) por meio da expressão fundadora: "gauche”. Ocorre, no entanto, que a expressão despe-se da mediação irônica do galicismo, neste momento.

O sentido político evidencia-se, quando não pela clareza do vocábulo (“esquerdo”) e pela expressividade da construção sintática (“fatal meu lado esquerdo”),

\footnotetext{
49 "Branqueamento da raça, marcadamente negra e mestiça, e desejo de civilização comandavam o imaginário cultural da nossa belle époque, Olavo Bilac à frente. Tratava-se de trocar o cenário colonial e abafado do Rio por outro, moderno e arejado como o de Paris. Acreditava-se que, reformando a fachada, o Brasil poderia entrar no concerto das nações plenamente civilizadas, das quais a França era o grande modelo. Afrancesandose, o Rio de Janeiro (e com ele todo o país) se 'desportuguesava'." Joaquim Alves de AGUIAR, Espaços da memória, p. 102.

50 SANT'ANNA, op. cit.

51 A solução artística drummondiana para a percepção e a problematização do indivíduo no mundo toca numa questão fundamental para as poéticas modernas, que em Fernando Pessoa leva ao fenômeno da heteronímia e na "Carta do vidente", de Rimbaud, à expressão: "Pois o Eu é um outro." (In: Carlos LIMA (org.), Rimbaud no Brasil, p. 15-18.

52 A esse diálogo entre o eu e uma suposta terceira pessoa, que na verdade é uma forma de monólogo, Merquior (op. cit.) denomina "personificação literária", enquanto Sant'Anna (op. cit.) denomina "diálogo a um".
} 
então pela inserção do poema no engajamento da obra, que vem a citar explicitamente trechos do Manifesto Comunista de 1848, escrito por Marx e Engels ${ }^{53}$. Ademais, a apropriação que o sujeito gauche faz da "mais límpida elegia” de "Vinicius”, por exemplo, enuncia uma agressão ao princípio da propriedade privada (“furto”), colocando-se, portanto, “à margem” da ética capitalista na estética do poema. Cabe notar que a "clareza” do que se furta é imediatamente "escurecida” pelo ato "sinistro", por meio do qual “confraternizam” os artistas e, por extensão, as suas artes.

O denominador comum a todos esses indivíduos e a todas essas individualidades é a "poesia sem purezas"54, que remete a vanguardistas contemporâneos, como Neruda, mas cujo antecedente primeiro é a poética de Baudelaire, a quem Drummond alude já em Alguma poesia ${ }^{55}$. Em “Consideração do poema”, a poética de Baudelaire (ele também um Carlos) não se evoca pela figuração explícita do autor, mas pela citação do poema "O albatroz" ("aves de bico longo conferindo sua derrota”, v.38-39), que funciona como alegoria do trabalho precário dos "poetas” na modernidade. Desse ponto de vista, mais do que rupturas com a sua obra pregressa, Drummond parece sugerir continuidades, que se ampliam. Parece sugerir, também, que estética e política encontram-se integradas, e não antinômicas.

O “lado esquerdo” é um lugar tão lírico quanto político num poema em que não há precedência da estética em relação ao engajamento, ou qualquer outro pressuposto dicotômico que oponha arte a sociedade, o que é ainda mais válido numa

\footnotetext{
53 Em dois momentos: no poema "Mas viveremos" (v. 13-16: "Já não distinguirei na voz do vento/ (Trabalhadores, uni-vos...) a mensagem/ que ensinava a esperar, a combater,/ a calar, desprezar e ter amor.”) e no poema "Com o russo em Berlim" (v. 65-68: "Essa cidade oculta em mil cidades,/ trabalhadores do mundo, reuni-vos/ para esmagá-la, vós que penetrais / com o russo em Berlim.”). Sublinhe-se no entanto que não é possível falar em adesão imediata às idéias de Marx e Engels, como de resto não é possível defender que Drummond tenha aderido irrefletidamente a nenhuma proposição de nenhuma natureza: filosófica, política ou mesmo estética. No caso das idéias "marxistas", ou "marxianas", A rosa do povo é ambígua: apropria-se de aspectos do instrumental teórico-metodológico, mas submete ao riso sardônico algumas contradições desse mesmo instrumental (veja-se, a propósito, o poema "O mito", entre outros) .

54 A expressão remete ao manifesto "Sobre una poesía sin pureza" de Pablo Neruda, publicado em 1935 em Para nacer he nascido, em que o autor defende a legitimidade das práticas sociais cotidianas como matéria de representação artística. A influência de aspectos estilísticos nerudianos em Drummond não se restringe apenas à "gravata chamejante", isto é, à eloqüência engajada (que Drummond, embora pratique, entretanto, o faz com distanciamento auto-irônico, cf. o poema "América", v. 21-28). A riqueza temático-formal em $A$ rosa do povo assume aspectos surrealistas em diversos momentos (vejam-se poemas como "Rola mundo"), em cuja prática Neruda foi um dos precursores (Saul YURKIEVITCH, Fundadores de la nueva poesia latinoamericana, p. 176). Em entrevista de 1944 a Homero Sena (Sonia BRAYNER, Carlos Drummond de Andrade, p. 26), Drummond afirma a necessidade de estudos sobre a poética moderna, e aponta como exemplar o estudo de Amado Alonso, Poesia y estilo de Pablo Neruda. Por fim, cabe ressaltar o que o próprio Drummond sublinha, logo no primeiro poema de $A$ rosa do povo, que dialoga com poéticas diversas, numa espécie de justaposição cubista. (Merquior, op. cit., p. 11-12, aponta para essa característica em "Poema de sete faces", o primeiro de Alguma poesia.)

55 Veja-se, entre outros, o poema "Carta a Stalingrado", p. 61.
} 
obra cuja problemática envolve a denúncia da "reificação", isto é, da intransitividade entre a dimensão simbólica e a dimensão sócio-econômica. Que o "lado esquerdo” seja um espaço-tempo em que se “incorporam” diferentes estéticas sob a perspectiva da crítica ao capital, isto sublinha, em vez de diminuir, a importância do indivíduo. O lirismo é o lugar da experiência subjetiva, não apenas em termos de afetividade, mas também em termos de intelecção, experiência que se torna efetiva graças ao trabalho com a linguagem mediante a volição autoral e o envolvimento público, diante de contextos que se inter-relacionam. É essa dimensão integrativa e intersubjetiva que justapõe aspectos diversos e metonímicos no "lado esquerdo".

Cabe notar, ainda, que a dimensão volitiva plasma os recursos do poema segundo as necessidades e o desejo do sujeito lírico, não como intransitividade, mas, ao contrário, como posicionamento da subjetividade diante do real que o comporta, mas que também o transcende. O “lado esquerdo" da persona lírica é profundamente transitivo, na medida em que o eu descentra-se para, duma perspectiva privilegiada, observar a si e ao mundo de modo cognitivo (afetivo-intelectivo). Se é de trânsito que se trata, por mais que o eu marque o lugar de onde fala e pareça ampliar, ou reduzir, a sua subjetividade em relação a outras subjetividades ou em relação a outras realidades objetivas, ele pode se figurar maior ou menor que o mundo ${ }^{56}$, conforme a reificação se enuncie (como denúncia e/ou ou como superação). Em quaisquer dessas posturas, a perspectiva será sempre a do lirismo em que o eu recusa a escala do monumento, daí a importância de figurar a temporalidade cotidiana.

Embora o eu recuse qualquer sentido transcendente para a existência humana, ele afirma a importância da volição e da subjetividade no rumo da história, mas sabe também que essa importância é relativa. A subjetividade não é algo essencial, porque se faz em diálogo permanente com o mundo, numa determinação recíproca. Nisso está a chave para o entendimento do vocábulo "fatal”, que se antecipa na importante expressão “fatal meu lado esquerdo", sendo assim muito expressivo.

“Fatal” é um termo polissêmico. Pode marcar uma atração irresistível, e nesse sentido adquire uma significação gregária no contexto do poema. Pode, ao contrário, significar algo funesto, que provoca a morte, sentido que o poema também comporta, na

\footnotetext{
56 SANT'ANNA (op. cit.) propôs que não é possível atribuir à obra drummondiana momentos contraditórios ou "fases", porque haveria uma estrutura dramática inerente à obra, responsável por uma coerência profunda, a percorrer os diversos momentos. Pela natureza gauche e relacional da personagem, o deslocamento do eu lírico (displaced) determinaria momentos em que o eu se iguala ou diferencia-se do mundo.

A presente pesquisa inspira-se nesta idéia, embora recuse o seu esquematismo ahistórico e, principalmente, a proposta de um Drummond "metafísico".
} 
medida em que o seu contexto de produção, que em diversos momentos vem enunciado, é o do Nazi-fascismo, ou seja, um momento em que as poéticas - e os escritores tiveram um importante papel de poder ou de contrapoder, caso em que foram perseguidos, torturados e mortos ${ }^{57}$. É ainda possível um terceiro significado para "fatal": algo inevitável, inexorável, marcado pelo destino para acontecer. Este significado, em princípio, negaria a importância da volição individual, que é marca tão importante nesse poema e em todo A rosa do povo. No entanto, esse sentido está presente quando o autor denuncia a reificação: em seus aspectos objetivos (na figuração do tempo capitalista tripartite, por exemplo, em poemas como "Nosso tempo") e em seus aspectos subjetivos (quando a subjetividade não consegue romper com o papel social que lhe é imposto pela família, por exemplo, na chamada “lírica familiar”).

Vagner Camilo, a propósito de outro momento drummondiano (o livro Claro enigma, de 1951), identifica a presença de elementos de uma cosmovisão trágica, na medida em que o eu lírico apresenta uma recusa violenta à ação, já que se vê sujeito a forças inexoráveis da existência e da história, forças que são inteiramente alheias a sua vontade e que apresentam ao limitado humano o ilimitado da fatalidade (Fatum). Não se trata, porém, de conformismo, o que se percebe pela estética violenta, em que a perplexidade lírica reage à impotência através da figuração da culpa ${ }^{58}$. Em certa medida, isto se faz também n A rosa do povo, vejam-se os versos de "Como um presente":

59. É talvez um erro amarmos assim nossos parentes.

60. A identidade do sangue age como cadeia,

61. fora melhor rompê-la. Procurar meus parentes na Ásia,

62. onde o pão seja outro e não haja bens de família a preservar.

63. Por que ficar neste município, neste sobrenome?

64. Taras, doenças, dívidas; mal se respira no sótão.

65. Quisera abrir um buraco, varar o túnel, largar minha terra,

66. passando por baixo de seus problemas e lavouras, da eterna agência do correio, $e$

[inaugurar novos antepassados em uma nova cidade.

67. Quisera abandonar-te, negar-te, fugir-te,

68. mas curioso:

69. já não estás, e te sinto,

\footnotetext{
57 Durante o Estado Novo, diversos artistas e intelectuais foram presos. Nos governos totalitários, como o da Alemanha, muitos exilaram-se ou terminaram reclusos em campos de concentração, onde sofreram tortura e foram mortos. A experiência do exílio, da censura, da reclusão, da tortura e da morte cala fundo em diversos momentos de $A$ rosa do povo, de maneira especial nos poemas reunidos por Iumna SIMON no já referido "bloco do fechamento", e que analisaremos na Segunda Parte desta dissertação. Um dos acontecimentos significativos dessa situação foi o filósofo Walter Benjamin, que, fugindo à perseguição nazista, cometeu o suicídio ao tentar entrar na Espanha.

58 Vagner CAMILO, Drummond: da Rosa do Povo à Rosa das Trevas, p. 227-298.
} 
70. não me falas, e te converso.

71. E tanto nos entendemos, no escuro,

72. no pó, no sono.

As regiões infernais da memória, em que a persona do gauche mergulha para exumar o que foi mas também para compreender o que poderia ter sido, são também “o fatal meu lado esquerdo”. É dessa perspectiva “sinistra”, “inexorável” e “mortal” que o trânsito entre o eu e o mundo resulta, na forma das "inquietudes”. Esse trânsito adquire diversas dimensões: umas mais autobiográficas (como a postura “à esquerda” na família), outras mais autobibliográficas (no caso de “Consideração do poema”, a perspectiva da personalidade literária gauche), outras ainda intersubjetivas (quando diversas poéticas cruzam-se e “incorporam-se”) ou políticas (a denúncia do capitalismo). No entanto, embora diversas perspectivas se interpenetrem, o ponto de partida está dado: o lirismo, cuja escala é o indivíduo, cuja temporalidade é o cotidiano e que se recusa terminantemente ao monumental.

Nas estrofes anteriores, figuram-se movimentos fragmentários, de início no plano das unidades expressivas do poema, cuja temporalidade é a sincronia, em seguida no plano em que o texto explicita os contextos poéticos a que pertence, remetendo portanto à diacronia. Sob a aparente fragmentação, existe uma unidade conceitual que expressa o ato poético como trabalho, não no sentido reificado, mas como ato capaz de ressignificação. Isto se verifica, na segunda estrofe, com a evocação do poema "No meio do caminho” através da imagem da pedra, cujo significado abrange toda a obra drummondiana e também o movimento artístico que ela integra, bem como outros movimentos com os quais dialoga, de tal modo que se efetua o trânsito entre dimensões diversas mas que, justapostas, interpenetram-se. Esse jogo de ruptura e integração pode ser percebido não só na imagística dessa estrofe, mas também em sua sintaxe, uma vez que todos os versos são truncados pela pontuação e pelo enjambement, e nenhum, exceto o último, tem, em si, sentido completo.

A figuração da prática poética, restrita ao aspecto ornamental e reduzida a “rima”, sofrera uma espécie de paródia na primeira estrofe, marcando a recusa do eu 
lírico. O "poema da pedra”, evocado na segunda estrofe, veio a reiterar aquela recusa, reafirmando os compromissos poéticos, não apenas em termos lingüísticos, mas também em termos biográfico e sócio-político. Assim, embora houvesse uma mudança de tom de uma estrofe para outra, a coerência textual reforçara-se.

O tom declarativo da segunda estrofe ("Estes poetas são meus. .../ é toda minha vida que joguei.”), em que aspectos de diversas outras poéticas justapuseram-se para compor uma espécie de auto-retrato artístico, reitera-se na terceira estrofe, mas modificado. O primeiro verso desta estrofe (“Estes poemas são meus. É minha terra”) retoma a estrutura sintática do terceiro verso da estrofe anterior, mas com a significativa transformação de “poetas” por “poemas”. Trata-se, portanto, de estabelecer uma certa regularidade, muito embora prevaleça a aparência de ruptura. O tom permanece declarativo, assim como prossegue o auto-retrato, mas agora o movimento é o da exterioridade. Enquanto na segunda estrofe o trânsito partira de "meu” e "me” para retornar ao sujeito, girando em torno do campo semântico da “incorporação”, agora, o trânsito parte do "meu” em direção ao "qualquer” e ao "tudo", segundo o campo semântico de "explosivo, sem fronteiras" (cuja idéia de ruptura, no entanto, se diferencia de "rasgar" e de "mesquinhez”). O poema prossegue com bruscas guinadas de estrofe a estrofe, tratando duma mesma problemática, mas segundo perspectivas diversas.

Na primeira estrofe (um octeto), formaram-se dois grupos de versos: os quatro primeiros, declarativos, marcados pelo futuro do presente, e os quatro últimos, descritivos, marcados pelo presente do indicativo. Na segunda estrofe, de onze versos, o tom declarativo, marcado pelo presente, restringira-se aos três primeiros e aos três últimos versos; os cinco versos do meio mesclaram tons e tempos verbais (pretérito perfeito, presente do indicativo, presente do subjuntivo), como que inserindo na poética do "meu” e do "me” diversas temporalidades. Nessa terceira estrofe, há três temporalidades: o presente do "ainda” (do primeiro verso ao sexto e nos três últimos); o futuro do pretérito, interrogativo (do sexto ao sétimo); e o presente do subjuntivo (oitavo). Nota-se, entretanto, que o presente traz em si o sentimento da perda, que o futuro do pretérito reforça o presente como o momento das escolhas e que o presente do subjuntivo aponta para o devir, de modo que a experiência subjetiva da historicidade é intensa.

Muito significativo, nesse sentido, é o quinto verso, que insere uma tripla interrogação na forma de diálogo, recurso esse que, de fato, amplia o discurso poético 
na direção do espaço público, não apenas porque reivindica como matéria de poesia a guerra, a esfera da economia e outras dimensões da vida em sociedade e da conjuntura em que a escrita se insere, mas sobretudo porque figura, no plano do discurso, a interlocução.

Já havia, nas estrofes anteriores, marcas explícitas do discurso lírico: uma hipertrofiada escala subjetiva, mesmo quando sob o tom declarativo, que na verdade mais traçara um auto-retrato literário que enunciara princípios estéticos. Na primeira estrofe, a metalinguagem temático-formal evidenciara a volição, afirmando a subjetividade como dimensão preponderante do trabalho poético. Na segunda estrofe, o trabalho poético evidenciara a intersubjetividade, eivada da perspectiva do sujeito do discurso cujas marcas vinham explícitas (os elementos dêiticos "meu”, com suas variantes, e “este”). A terceira estrofe retoma esta perspectiva de maneira amplificada, pela reiteração do verso em que o sujeito do discurso sublinha o seu lugar ("Estes poemas são meus. É minha terra”) como premissa para a alteridade (“e é ainda mais do que ela./ É qualquer homem/ ao meio dia em qualquer praça. ...”). Nesse momento, a interlocução também se evidencia, pela inserção da fala e de eventos alheios, de modo tão expressivo quanto o lugar do eu.

De certo modo, o truncamento da sintaxe e dos versos, bem como os recursos metonímicos, são o contraponto do pathos elevado e da subjetividade hipertrofiada ${ }^{59}$, porque incorporam o outro e os eventos externos ao discurso lírico e, assim, constroem

\footnotetext{
${ }^{59}$ Merquior afirma: "Em todos os casos, esse tom [o de poemas engajados, como os da "lírica de guerra"] traz consigo uma linguagem que roça o insípido, de baixa voltagem poética. De uma certa maneira, "A Rosa do Povo" mata o estilo neo-romântico, formado na juventude do lirismo drummondiano, acentuando-lhe os defeitos. Que a inclinação para o sublime, o recrudescimento do pathos idealizante não suporta o confronto com o verso musculoso do estilo mesclado, é o que ressalta em 'A Flor e a Náusea'.” (op. cit., p. 104, grifo do autor).

Discordamos desses pressupostos, na medida em que não é possível abordar aspectos (temáticos e/ou estilísticos) em $A$ rosa do povo de maneira fragmentária, sob pena de restringir a pluralidade - que é o sentido último da poética drummondiana, profundamente integrativa. O crítico valoriza teleologicamente alguns "estilos" em detrimento de outros, com base apenas no julgamento de valor, perdendo de vista as dimensões concorrentes da sincronia e da diacronia - cuja interação ele próprio anunciara como meta para o seu trabalho (p. 3-4), mas que não chega a cumprir plenamente nos momentos em que tece julgamentos estéticos tendo como base pressupostos teóricos no mínimo discutíveis. Veja-se, por exemplo, a apreciação da postura intelectual de Drummond:

"O autor de $A$ Rosa do Povo não tem a sensibilidade conservadora de um José Lins do Rego; é antes um intelectual socializante, se bem que seja bastante lúcido para falar no auge de seu engajamento ideológico - de "mitos" proletários (in "Idade Madura", RP, p. 186, v. 53); conservará sempre o estofo de um liberal de esquerda." (op. cit., p. 93, grifo do autor)

Se à época de Verso universo (1975) o desencanto de Drummond com o socialismo estava patente, como demonstra a análise de Vagner Camilo (op. cit.), entre 1943 e 1945, no entanto, Drummond situa-se claramente, em sua poética mas também em sua prosa, no campo intelectual socialista. Por isso, a crítica de Merquior, quando perde a dimensão do contexto, em vez de tecer juízos de valor coerentes, sobrepõe, com pouca ou nenhuma consciência disto, o seu próprio contexto bipolar de "Guerra Fria" como horizonte da poética que examina - com prejuízo de seu juízo estético.
} 
alteridade, ao mesmo tempo que figuram a reificação capitalista, num "tempo de partido,/ tempo de homens partidos., 60

Há uma progressão de predicados nominais do primeiro ao quarto versos, toda ela feita de “saltos”. O verbo do primeiro período (“são”) “salta” do plural para o singular (“é”) para estabelecer uma série amplificada e vertiginosa de equivalências por diversos períodos, cujo sujeito é o mesmo “poemas” do período inicial, ele mesmo um “salto” em relação à estrofe anterior (dos "poetas incorporados ao fatal meu lado esquerdo” aos “poemas”). Trata-se de uma ligação muito sugestiva, porque enuncia a aproximação ao figurar um espaço dilacerado.

É dessa forma que os significados correntes tornam-se matéria de poesia. O mundo do capital, que mutila os significados sociais, como o do trabalho, reduzindo-os ao valor de troca, encontra-se ele mesmo incorporado à expressividade fragmentária do poema. Em certa medida, o universo simbólico do capital organiza a afetividade do sujeito poético, incapaz de estabelecer equivalências imediatas entre as coisas e os seus nomes. A figuração metonímica, ao mesmo tempo que estabelece uma distância entre o objeto e sua representação, estabelece também uma nova possibilidade de significados, por meio da mediação cognitiva. Assim, aspectos da guerra ("mortos”) e da produção da vida material ("mercados”, “comércio”) tornam-se "poemas”: evocados como fragmentos e justapostos como parte de um significado mais amplo, que não se revela na sua inteireza.

Através dessa forma fragmentária, o contexto se incorpora ao texto: como parte orgânica de sua fatura. Há diversos aspectos contextuais presentes no poema, sem que, com isso, o texto perca em densidade significante; ao contrário: a forma é eficaz, por isso é possível incorporar o contexto sem prejuízo para o texto. O processo metonímico de representação fragmenta os significados e a forma, e, já ao fazê-lo, estabelece analogias e equivalências. Dessa maneira, o sentimento nacional e a guerra são denunciados como estilhaços dum mecanismo maior, cujo (sem-)sentido é a produção do lucro, a cindir significantes e significados ${ }^{61}$. A esse movimento tanático, a perspectiva rigorosamente internacionalista e individual do lirismo contrapõe o eros do “beijo”. Não por acaso, é nessa terceira “face” do auto-retrato que se dá o encontro com

\footnotetext{
${ }^{60}$ Referência aos dois primeiros versos de "Nosso tempo", sétimo poema de $A$ rosa do povo.

${ }^{61}$ Henri LEFEBVRE, op. cit., p. 62-79.
} 
outra voz, que não a do sujeito lírico; e, nesse mesmo momento, a dimensão autobiográfica sugere-se imediata ${ }^{62}$.

A terceira estrofe formalizara a interlocução no discurso poético subjetivo, cruzando outras vozes com a fala da persona lírica, numa espécie de tecido onde se encontraram, primeiro, as microdimensões do texto, depois, os intertextos e, por último, o contexto. Esse encontro, no entanto, faz-se contraditório, porque, de um lado, há a vontade poética do "beijo” mas, de outro, há a destrutividade no mundo, de tal maneira que ir de encontro ao mundo significa enfrentar a desintegração. Há diversos índices de truncamento do discurso porque ele figura um mundo em desintegração; por outro lado, os fragmentos figurados interconectam-se de maneira analógica segundo a vontade poética e, assim, transfiguram a precariedade objetiva. Daí, a importância de fragmentar as significações e os significados, como forma de rearticulá-los, transfigurando-os.

No poema, é possível identificar dois princípios: eros (“rima”, “incorporação”, “beijos”) e thanatos (“não”, “fatal”, “mortos”), nenhum deles, porém, absoluto, porque ambos se cruzam e interpenetram. Há muitos índices de negatividade, mas todos participam do trânsito da interioridade subjetiva à exterioridade objetiva. Se esse encontro traz indícios de precariedade, no mundo torto mas também no eu torto, é porque ela resulta da contradição entre o desejo gregário e a realidade desintegradora. A precariedade relativa é a busca autoral por superar o conflito; revela-o, mas transfigurado. A transitividade enunciada (tematicamente) e a intransitividade denunciada (formalmente) entrelaçam-se para transfigurar a contradição no movimento complexo do poema. O plano da expressão resulta dos diversos entrecruzamentos, tornando-se síntese.

Esse metapoema, embora se proponha ao encontro, apresenta uma articulação dificultosa de palavra a palavra, de frase a frase, de estrofe a estrofe. São índices dessa negatividade: o truncamento sintático; as bruscas mudanças de tom; as interrogações na

\footnotetext{
62 Ainda que se faça em terceira pessoa ("Que se depositem os beijos na face branca, nas principiantes rugas.”), a alusão é ao próprio poeta, nascido em 1902, e que à época do livro, portanto, tinha em torno de quarenta anos, o que se explicita mais de uma vez nesse livro. Veja-se nesse sentido o poema "A flor e a náusea": "Quarenta anos e nenhum problema/ resolvido, sequer colocado.".
} 
terceira e na sexta estrofes; os termos “não”, “nem”, “ainda”, “embora”, “mas”, “sem”, “apenas”, "sequer”; o campo semântico proposto pelos vocábulos "fatal”, "mortal”, “mortos”, “doenças”, “mercados”, “comércio”, “explosivo”, “falsa”, “mesquinhez”, “sujos”, “raras”, “secretas”, “duras”, “perco”. Mas nenhum desses índices comporta uma negatividade absoluta, porque participam do trânsito entre os princípios opostos.

Cada fragmento, semântico e/ou formal, termina por evocar uma totalidade. O truncamento sintático aniquila o verso como unidade de significação no poema, mas cria um efeito expressivo de liberdade ao transferir o significado para unidades mais amplas, além de expressar a carga lírica emotiva e volitiva. (Entenda-se liberdade como transitividade, e não como ausência de vínculos.) As mudanças bruscas de tom permitem uma multiplicidade de perspectivas complementares. A interrogação é um dos recursos que promovem o trânsito entre o “eu” e o “tu” no discurso lírico, e o enfrentamento da exterioridade convencional pela interioridade libertária. Os termos imbuídos de negatividade promovem o enfrentamento entre contrários. Do mesmo modo, o campo semântico dos vocábulos relacionados a “morte” revelam aspectos que integram a vida, entendida como fenômeno orgânico. De tal modo que o todo do poema é composto por partes que não se articulam de maneira imediata, mas mediada pela linguagem “retorcida”, cujo efeito expressivo é, entretanto, plenamente integrativo.

Assim é que o auto-retrato poético multifacetado chega à quarta estrofe reunindo, numa só alegoria, e integrados, todos os elementos do discurso, antes figurados separadamente. Aqui, se entrelaçam as dimensões de autor, público, texto e contexto, em estruturas cujos verbos mais importantes encontram-se no infinitivo impessoal ou elípticos (com a expressiva exceção em "Essa viagem é mortal”, a que se segue, no entanto, a oração coordenada “e começá-la.”).

Pela primeira vez no poema, o sujeito lírico não evoca aspectos de si para compor o auto-retrato, figurando-se por completo (como “poeta” e como “cantor”, muito embora logo se reduza a "boca”, “ardor” e, por último, a “canto”). Mas nem por isso abandona o descentramento do gauche, visto que enuncia a precariedade da persona poética para, contraditoriamente, atribuir ao indivíduo dimensões múltiplas, profundamente transitivas.

Há um contexto para o eu torto, que figura a si próprio com um máximo de inteireza para poder fazer frente ao mundo torto com um mínimo de integridade. Ainda assim, não é de heroísmo que se trata, ao contrário, a escala lírica reforça a recusa do monumental e do mecânico. A precariedade do mundo se incorpora ao "fatal meu lado 
esquerdo”, então o sujeito, embora afirme “dar tudo pela presença dos longínquos”, tem a exata dimensão do "meio" em que se "move”, bem como de seus próprios recursos humanos, portanto "finitos" e "mortais". Sabe perfeitamente que o seu "canto" não é apenas a emissão de sons, mas também a consciência de todos os fatores que envolvem o discurso, não apenas o "meio" e a "forma-navio", mas também o lugar de onde se fala (o “canto") e para quem se fala ("longínquos”). Isso porque não visa à comunicação mimética (isto é, ao mero registro), mas sim à transfiguração. Este, aliás, é o sentido explícito do recurso à alegoria. Mais uma vez, o trabalho poético figura a si próprio de maneira a explicitar-se como construção humana, isto é, como trabalho, como ato volitivo-cognitivo prenhe de sentido, imbuído entretanto dum profundo senso do real.

Quanto ao “meio”, a alegoria é suficientemente ampla para tratar do ato poético nas suas dimensões sincrônica e diacrônica. Há a referência à densidade específica da linguagem poética, a “mover-se em meio a milhões e milhões de formas raras, secretas, duras”, num lugar distante o suficiente da subjetividade poética para configurar uma experiência cognitiva, e não meramente confessional (num “aí”, mais próximo do receptor que do "eu” $)^{63}$. Por isso mesmo, esse lugar é transitivo, e não intransitivo, já que nele há diferentes mediações: entre os universos "sobre” e "submarino”, o “canto” se constrói como trabalho social, orgânico, ciente das mais diversas dimensões do real (o simbólico e o concreto).

O sentido último dessa alegoria, quando vista pelo prisma da diacronia - que não anula o prisma da sincronia -, é o contexto de escrita do poema, quando a guerra levou os países, e não apenas as ditaduras de inspiração nazifascista, como o Estado Novo, a restringir o acesso à informação e a policiar os mares. O governo de Vargas, por exemplo, mandava que se apagassem as luzes da capital brasileira, de outras cidades e dos faróis para evitar ataques marítimos, o que provocou funda impressão em Drummond, e vem expresso em diversos poemas de $A$ rosa do povo ${ }^{64}$. As batalhas

\footnotetext{
${ }^{63}$ Mais uma vez, a temática do poema consecutivo ("Procura da poesia") mostra-se presente, à medida que o "mover-se em meio a milhões e milhões de formas raras, secretas, duras" também pode formular-se como um "penetra surdamente no reino das palavras", "lá [onde] estão os poemas que esperam ser escritos (...) sós e mudos, em estado de dicionário."

${ }^{64}$ Murilo Marcondes de MOURA, Três poetas brasileiros e a Segunda Guerra Mundial, p. 59.

Vejam-se os poemas:

"Passagem da noite", v. 10-18 ("Sinto que é noite no vento,/ noite nas águas, na pedra.// E que adianta uma lâmpada?/ E que adianta uma voz? / É noite no meu amigo./ É noite no submarino./ É noite na roça grande./ É noite, não é a morte, é noite/ de sono espesso e sem praia./ Não é dor, nem paz, é noite, /é perfeitamente a noite.");

"Rola mundo", v. 70-79 ("Como vencer o oceano/ se é livre a navegação/ mas proibido fazer barcos?/ Fazer muros, fazer versos,/ cunhar moedas de chuva,/ inspecionar os faróis/ para evitar que se acendam,/ e devolver os cadáveres/ ao mar, se acaso protestam,/ eu vi; já não quero ver.’);
} 
submarinas eram fundamentais durante a Guerra, e configuraram um dos motivos importantes para que o Brasil de Vargas se alinhasse aos Aliados contra o Eixo, provocando uma contradição no regime político totalitário que terminou por forçar a “redemocratização” do país. Além disso, a ditadura de Vargas fez do mar um espaço em que presídios, tortura e mortes visavam ao combate dos "crimes de opinião”, o que, aliás, explica o tom cifrado da "mensagem” e o seu caráter de "risco".

Ainda em termos diacrônicos, está clara a referência ao poema “O albatroz”, de Baudelaire, o que permite que o contexto também apresente uma temporalidade mais profunda que a da conjuntura imediata. Ainda assim, não é apenas de "linguagem”, entendida no sentido "intransitivo" (isto é, intemporal, ou numa temporalidade que supostamente se contrapõe à dos eventos concretos), que se trata, porque a própria poética baudelaireana, embora venha sendo apropriada de acordo com os mais diferentes contextos, remete a uma conjuntura específica, qual seja, o período após 1848, em que Napoleão III afirma na França o imperialismo francês, para o descontentamento dos intelectuais boêmios e dos artistas ${ }^{65}$.

Por último, cabe notar que, nesta estrofe, a interlocução realiza-se em toda a complexidade do discurso. Toda a dificuldade encontra-se figurada, de maneira muito expressiva, mas de fato a "mensagem” (“esta”) termina por cumprir a "viagem mortal”

"O mito", v. 101-104 ("Me ponho a correr na praia./ Venha o mar! Venham cações!/ Que o farol me denuncie!/ Que a fortaleza me ataque!');

"Notícias", v. 1-14 ("Entre mim e os mortos há o mar/ e os telegramas./ Há anos que nenhum navio parte/ nem chega. Mas sempre os telegramas/ frios, duros, sem conforto.// Na praia, e sem poder sair./ Volto, os telegramas vêm comigo./ Não se calam, a casa é pequena/ para um homem e tantas notícias.// Vejo-te no escuro, cidade enigmática./ Chamas com urgência, estou paralisado./ De ti para mim, apelos,/ de mim para ti, silêncio./ Mas no escuro nos visitamos."); v. 20-23 (“Os telegramas vieram no vento./ Quanto sertão, quanta renúncia atravessaram!/ Todo homem sozinho devia fazer uma canoa/ e remar para onde os telegramas estão chamando.");

"Mas viveremos", v. 9-12 (“Já não olharei sobre o oceano/ para decifrar no céu noturno/ uma estrela vermelha, pura e trágica,/ e seus raios de glória e de esperança."); v. 37-40 ("No mar estava escrita uma cidade,/ no campo ela crescia, na lagoa,/ no pátio negro, em tudo onde pisasse/ alguém, se desenhava tua imagem,"); v. 64-72 (“Ele chegará, ele viaja o mundo./ E ganhará enfim todos os portos,/ avião sem bombas entre Natal e China,/ petróleo, flores, crianças estudando,/ beijo de moça, trigo e sol nascendo.// Ele caminhará nas avenidas,/ entrará nas casas, abolirá os mortos./ Ele viaja sempre, esse navio,/ essa rosa, esse canto, essa palavra.");

"Visão 1944", v. 1-4 ("Meus olhos são pequenos para ver/ a massa de silêncio concentrada/ por sobre a onda severa, piso oceânico/ esperando a passagem dos soldados."); v. 13-20 ("Meus olhos são pequenos para ver/ a bateria de rádio prevenindo/ vultos a rastejar na praia obscura/ aonde chegam pedaços de navios.// Meus olhos são pequenos para ver/ o transporte de caixas de comida,/ de roupas, de remédios, de bandagens/ para um porto da Itália onde se morre.”); e. 91-94 (“Meus olhos são pequenos para ver/ essa mensagem franca pelos mares,/ entre coisas outrora envilecidas/ e agora a todos, todas ofertadas.");

"Com o russo em Berlim", v.37-40 ("Nas camadas marítimas, os peixes/ me devorando; e a carga se perdendo,/ a carga mais preciosa: para entrar/ com o russo em Berlim.”); v. 45-48 ("Muitos de mim saíram pelo mar./ Em mim o que é melhor está lutando./ Possa também chegar, recompensado,/ com o russo em Berlim.”).

Veja-se, ainda, "Notícias de Espanha”, publicado em Novos poemas, em 1948.

65 Walter BENJAMIN, Charles Baudelaire. Um lírico no ange do capitalismo. 
(“essa”), a despeito de todos os riscos, e o faz não em tom de epopéia, visto não haver distanciamento no tempo, heroísmo ou mesmo uma narrativa plenamente configurada, mas num tom eivado de precariedades de todo o tipo. No final da longa estrofe de catorze versos $^{66}$, em que predominam as sugestões de irregularidades (embora haja regularidades), a frase é muito eloqüente: “Eis aí meu canto.” O discurso, cuja dêixis marcara o lugar pessoal do "eu” numa situação paradoxal de impessoalidade, explicita agora o trânsito efetivo do "meu” em direção aos "longínquos", contactados pelo “canto”, sem que a distância e a dificuldade deixassem de explicitar-se.

Enquanto as três primeiras estrofes configuraram um processo metonímico, a quarta figurou uma alegoria, cujo significado não se restringe ao contexto da estrofe, já que evoca os significados e os significantes construídos previamente, ampliando-os. Assim, os diversos elementos do discurso, antes figurados fragmentariamente, e justapostos numa espécie de retrato poético, na quarta estrofe entrelaçam-se num longo período, em que se enuncia a precariedade do trânsito, mas pratica-se um discurso articulado, a despeito da predominante sensação de irregularidade ${ }^{67}$.

A quinta estrofe é, entre todas, a que maior continuidade estabelece em relação à anterior. O último vocábulo da quarta estrofe (“canto”) é transposto ao primeiro termo da estrofe subseqüente (“ele”) sem que haja grandes rupturas tonais ou semânticas, o que cria um efeito expressivo de identidade entre as duas estrofes. O “canto”, palavra polissêmica que significa, a um tempo, o “poema” e a perspectiva em que se situa o

\footnotetext{
66 Esta estrofe, como as demais, tem uma certa regularidade no esquema métrico dos seus versos, predominantemente decassílabos, muito embora a irregularidade do esquema rítmico e, sobretudo, da sintaxe predomine. Os três versos que distoam do esquema métrico têm função orgânica no conjunto. O verso 32 é dodecassílabo, e trunca não apenas a métrica do conjunto estrófico, mas também a própria sintaxe, numa estrutura ternária, entremeada por vírgulas, em que o "sim" quer reforçar a secura do lirismo, mas termina por trair uma intensa emotividade. O verso 34 tem onze sílabas numa estrutura sintática fluente, mas que, embora persiga a "presença" do interlocutor, acaba sublinhando a distância ("longínquos"); a métrica, portanto, adequa-se à necessidade expressiva. O verso 41, também dodecassílabo, apresenta a única oração principal em que o verbo não está no infinitivo impessoal, é um verbo de ligação; mas a oração seguinte, coordenada, apresenta uma elipse muito significativa do contexto ditatorial em que o poema se engaja (o que é índice de engajamento, e não de "fechamento do discurso sobre si mesmo").

${ }^{67}$ A quarta estrofe, tomada no contexto mais amplo do poema, não deixa de funcionar como um fragmento entre os demais, importante na composição do auto-retrato poético. Mas vista como uma unidade de sentido, ela é a narrativa do trabalho poético, em que diversos elementos entrelaçam-se. Em cada estrofe anterior, o retrato poético não abarca a totalidade do discurso, mas na quarta estrofe, sim.
} 
“poeta”, aqui é tratado como um outro, uma terceira pessoa do discurso, o que confirma o deslocamento da “mensagem” (“esta”) em direção à exterioridade (“aí”). Essa alteridade é o universo da recepção (“escuta” ou “absorção”).

A “mensagem” emitida, após percorrer “meios” hostis (“mar negro”, “formas raras, secretas e duras”) de maneira precária (“ecos, poucos, mas cristal, não rocha apenas”), agora, busca identificar-se com diversos objetos num universo familiar e ordinário, não mais extraordinário. Esses objetos, receptivos (no sentido da "absorção" mas também no sentido do afeto, ou “carinho”), representam os mais diversos aspectos da vida em sociedade, desde o universo concreto dos cuidados com a "carne" (“remédios”) até o universo das representações simbólicas (“livros”, “cartas”, “colégio”), todos eles integrados ao "rés-do-chão”, não no sentido comezinho, aristocrático, em que o "baixo" contrapõe-se ao “alto", mas como a escala a partir da qual integram-se o "alto” e o "baixo”.

A horizontalidade de "mesa", "bonde" ou "rua" integra a verticalidade de “parede”, de tal maneira que o "baixo” e o "alto” entrecruzam-se ao “rés-do-chão", escala cotidiana a que se destina o “canto” (a um tempo “mensagem” e lugar do lirismo). O trânsito integrativo de todas as esferas da vida em sociedade inclui as “ondas” da “mensagem”, antes propagadas por meios hostis (“líquido”), mas agora “infiltradas” num meio acolhedor e integrativo (em "terra firme”). As envolventes “ondas de carinho” resultam da “transformação” dos objetos cotidianos em objetos poéticos. Essa equivalência não vem do mimetismo imediato, mas da transposição orgânica de sentidos, mediada.

Até à quarta estrofe, o eu figurava a si próprio de maneira complexa, ora explicitando-se, ora tornando-se implícito, mas de qualquer modo evocando aspectos do discurso poético num movimento em que diversos níveis justapunham-se e ampliavamse, tendo como epicentro a escala subjetiva do lirismo. Na quarta estrofe, esses elementos articularam-se numa simultaneidade narrativa, em que a persona lírica, a um tempo, figurava-se integral, mas sugeria índices de despersonalização. Nesta quinta estrofe, o “canto", lugar do lirismo, é que se torna o elemento mediador. A ele, equivalem o eu lírico (“cantor”) e diversos outros sujeitos do discurso. Prossegue, assim, a dinâmica do retrato poético. O canto integra-se ao "meio" sem, por isso, dissolver-se imediatamente nele. Os mais diferentes aspectos desse meio, transpondo-se ao canto, humanizam-se, impregnam-se da dimensão subjetiva do afeto. De certa maneira, a integração do "baixo" (esfera da produção material) e do "alto” (esfera da 
reprodução dos sentidos sociais) antropomorfiza os diversos objetos pela transposição de sentidos. Esta é uma estrofe predominantemente metafórica, em que a reificação é superada de maneira explícita.

É muito intrigante que do "ele” inicial se passe ao "te”, no fim da estrofe. Essa nova pessoa do discurso, o “tu”, que já havia aparecido pela primeira vez, muito brevemente, no décimo sexto verso (como “Maiakovski”) e pela segunda vez sob a interlocução do vigésimo quarto verso (“- Há mortos? há mercados? há doenças?”), agora se apresenta como uma persona integrada ao retrato poético.

Na identidade criada metaforicamente entre o “canto” e os objetos cotidianos, há algumas transposições que se enunciam e uma que se formaliza. O “canto”, que está ao "rés-do-chão", ao mesmo tempo "baixo" e "alto”, transpõe-se para a "pedra”, para os objetos sobre a "mesa” e para a "parede", e se vê envolvido pelo "bonde”, pela "rua” e pelo “uniforme do colégio”, tornados “onda de carinho”. Há, portanto, um trânsito multívoco entre o "canto" e os objetos, de tal modo que todos se tornam sujeitos do movimento. Sintaticamente, a expressão “te”, a exemplo do que ocorrera com o termo “canto”, é polissêmica. Refere-se, simultaneamente, ao “canto” (e, por extensão, ao poema e também ao lugar da persona gauche do "poeta”), mas refere-se, igualmente, ao leitor, destinatário real do metapoema que, por esse artifício de linguagem, vê transposta a figura simbólica do receptor ao seu equivalente concreto. Assim, as dimensões da autoria, da leitura e da obra, até então figuradas em separado como personae, integramse num mesmo lugar discursivo, graças à linguagem metafórica, que figura a si mesma como trabalho social.

Isso não significa que o poema seja predominantemente comunicativo ("não são jornais”), ao efetuar o trânsito entre a linguagem poética e a conjuntura, à maneira daquilo que se entende por “prosa”. Esta linguagem não é “imediata”, isto é, não tem como intuito exclusivo, ou predominante, engajar-se no tempo da "política" (e de outros eventos factuais), ou submeter a densidade lingüística à clareza das idéias e dos conceitos; é uma linguagem propriamente densa, em que o discurso apresenta diversos níveis de significação, todos complexamente entrelaçados e mediados por um sistema simbólico, cuja temporalidade é ressignificante. Entretanto, com não ser imediato, senão mediador, este discurso, muito embora não se reduza à diacronia dos “fatos”, tampouco isola-se na temporalidade exclusivamente sincrônica da linguagem em-si (identificável nos estudos lingüísticos predominantemente teóricos). Diversas perspectivas temporais e espaciais entrecruzam-se nesta metalinguagem, as mais imediatamente "finitas" e 
“materiais” como também as mais complexamente simbólicas, o que se faz possível em virtude - e não em prejuízo - do discurso poético, que recusa a separação alienante entre arte e sociedade e, por isso mesmo, tem dimensões que "não são jornais nem deslizar de lancha entre camélias”, para empregar a expressiva imagem do próprio metapoema. Trata-se dum sistema simbólico integrativo.

8

Na última estrofe analisada, o “canto” transformara-se num outro ponto de fuga do retrato poético, segundo o qual entrelaçaram-se as diversas pessoas do discurso: o "poeta” e os seus interlocutores (outros poetas e os destinatários, dentre os quais figurase o leitor). Os interlocutores, de "longínquos”, tornaram-se um "tu” afetuosamente “abraçado” pelo “canto”, graças à polissemia e à transposição metafórica de sentidos.

Do ponto de vista das estrofes, o poema descreve uma curva, na medida em que a primeira estrofe apresenta oito versos, a segunda e a terceira apresentam onze versos, a quarta, a maior de todas, apresenta catorze, a quinta reduz esse número bruscamente para sete versos e as duas últimas apresentam, igualmente, seis. O movimento desta sexta estrofe é, portanto, descendente. É preciso, contudo, inserir outras variáveis nesta imagem gráfica, para que se evidencie a complexidade do discurso ${ }^{68}$. Embora predominem decassílabos (quarenta e dois no total, contra vinte e um versos de outro metro), o truncamento sintático e rítmico e as bruscas mudanças de tom desviam a unidade significante do verso, da estrofe e de outros recursos lingüísticos para o plano conceitual, de tal modo que é a justaposição dos sentidos fragmentários que confere significado às partes e ao todo, em operações analógicas que se completam na atividade mental do leitor, ainda que a volição e a cognição autorais presidam a fatura.

Nessa sexta estrofe, figura-se novamente o "canto" como escala em que se encontram o "poeta”, o “poema” e o "receptor”, e em que transigem o "baixo"/

\footnotetext{
${ }_{68} \mathrm{O}$ pensamento cartesiano se expressa, graficamente, por uma relação entre duas variáveis, cada qual representada num eixo, resultando num ponto.Vale notar, entretanto, que, no período entre 1914 e 1945, a Era das Catástrofes (segundo Eric HOBSBAWM, in Era dos extremos, p. 29-219) é o momento em que as representações simbólicas sofreram profundas transformações, não apenas as artes, mas também a lógica dualista do pensamento cartesiano e a física newtoniana (assentada nas relações aristotélicas de causa-efeito), que não mais configuravam sistemas simbólicos capazes de conferir sentido ao mundo.
} 
“mínimo” e o “alto”/ “grande”,69, mas agora essa figuração não é mais metafórica. A transposição de significados assume um caráter de mediação explícita. O “como” da pergunta que o sujeito lírico propõe tem sentidos diversos: reforça a interlocução com o “tu” e sublinha o aspecto volitivo-cognitivo do ato poético. Por isso, ao repetir-se por três vezes, estabelece uma comparação cujos termos se explicitam. Não é mais o pensamento metafórico que estabelece a transposição de sentidos. A transposição, através do símile, sublinha o significado de trabalho social que o ato poético assume, na medida em que os termos equivalentes aparecem lingüisticamente mediados.

A estrofe denota claramente que não é de comunicação que se trata, na medida em que o "canto” não se reduz a "temas”, ainda que nele caibam igualmente o "grande” e o “mínimo”. A “passagem” dos “temas” não esgota o “canto”, já que é um fenômeno imediato; o "canto” se expressa por mediações lingüísticas impregnadas de significados sociais diversos. Nem o ato poético nem as pessoas do discurso reduzem-se ao imediato, o que não significa que o "canto" seja intemporal, uma vez que trata do "finito" e da “matéria”, integrados, porém, ao discurso pela mediação na escolha das "palavras”, considerando-se o real concreto e o real simbólico.

A última relação que o símile estabelece, entre o "tu” e o "orvalho entre dedos que repousam na grama”, provoca, sintática e sinestesicamente, o efeito de enlace entre os “dedos” e a "grama”, destacando "repousam” como termo posposto e "grama” como termo ambíguo: anteposto no plano do último verso da estrofe mas deslocado para o meio sintático da construção “dedos que repousam”. Dessa forma, o efeito de evidenciar a volição no ato criativo, sem, entretanto, diminuir seu caráter cognitivo (que concilia afeto e intelecção), termina por ressaltar-se, intensificando, também, o campo semântico dos elementos “fogo”, “terra”, “água” e “ar”, já previamente utilizados. Essa sinestesia acaba por provocar um efeito de amálgama, não apenas sensorial, mas também semântico.

"Fogo” remete à "gravata chamejante de Neruda”. "Casa” remete a "estalagem” e aos elementos metonímicos “parede”, “mesa”, “chão” e “pedra”, todos eles “terrestres” (“Estes poemas são meus. É minha terra e é ainda mais do que ela”). “Orvalho” remete a "água”, a cujo campo semântico pertencem as seguintes imagens: “deslizar de lanchas entre camélias”, "beijo [como] sinal, perdido embora, da ausência de comércio, boiando em tempos sujos”, "peixes circulando sob o navio que leva esta

\footnotetext{
${ }^{69}$ Note-se que os termos "baixo" e "alto" ampliam-se com os hiperônimos "mínimo" e "grande".
} 
mensagem”, “mar negro”, “na parede infiltrou-se”; e, na medida em que “orvalho” é um fenômeno atmosférico, termina por evocar também imagens aéreas, como "as palavras [que] saltam, se beijam,. se dissolvem, no céu livre por vezes um desenho”. “Orvalho” ainda evoca "noite” e, por extensão, “sono”, problema central proposto na primeira estrofe e que se amplia, metonimicamente, para toda a metalinguagem do poema. Portanto, a enumeração no mesmo período de “fogo”, “casa” e “orvalho”, em estruturas com função sintática equivalente, provoca a justaposição dos sentidos, os próprios e os metonímicos, de todo o poema, que figura a si próprio em profundidade.

Por fim, cabe notar que o verso "eu sei que [eles] passarão, mas tu resistes," agrega, na mesma estrutura, três pessoas pronominais: “eu” (antes sintaticamente oculto ou transformado numa terceira pessoa - “poeta”, “cantor” -, representando a persona do gauche, agora pela primeira vez explícito), “eles” (que aqui substituem “temas”, mas

que havia sido empregue em lugar de "poetas”, "poemas”, “beijos”, "bonde/ rua/ uniforme de colégio”) e "tu” (que é o “canto”, lugar em que se constrói a identidade/ alteridade entre autor, obra e público).

Nessa estrofe final, reafirma-se o caráter interlocutório promovido entre as pessoas do discurso, o “eu” e o “tu”, pela mediação do “poema”, num jogo ao mesmo tempo de identidade e de alteridade, que assinala tempos e espaços múltiplos.

O longo período enumera ações que se articulam por coordenação, situando-as num presente que incorpora outras temporalidades, porque traz em si a consciência de ser plural. O recurso a “já agora” e a “toda parte” estabelece, na perspectiva do instante, a pluralidade de caminhos. $\mathrm{O}$ eu, em sua busca por identificar-se com o outro, percebese a si próprio como um ser plural, que recusa a linearidade lógica e se apropria do paradoxo e do movimento dialogal. O impulso ao encontro (“desejo”), embora comporte a contradição do desencontro ("perco"), não se esvazia de significações ("estou completo", “cheio de segredos”) ou das mais diversas possibilidades ("me destino”). De fato, a articulação das várias orações não estabelece linearidade nem um plano unívoco, mas sim o movimento em amplas direções, que partem da subjetividade em direção ao outro, sem o reduzir, nem, tampouco, reduzir a si própria, abrindo, ao 
contrário, diversas possibilidades, expressas pelas reticências e confirmadas pela sintaxe final.

O estranhamento da sintaxe é a marca expressiva desse jogo, em que se estabelecem as identidades ao marcarem-se as diferenças. A "lâmina” é fator, a um tempo, de aproximação e de separação, espelhamento este que se sublinha pelo recurso ao símile. "Povo" e "poema” podem ser tomados como termos equivalentes, comparados à "lâmina” que atravessa quem lê; neste caso, o eu-lírico explicita o público como seu interlocutor (o “tu”). É possível considerar, também, que quem “atravessa” o “poema” como “uma lâmina” é o "povo”; neste caso, o "tu” do discurso é o próprio poema. De todo modo, o retrato poético termina por cruzar, no lugar do poema, todas as pessoas do discurso como sujeitos em diálogo especular, que não confunde a especificidade de cada papel ou lugar, embora promova o encontro efetivo de todos eles. Com isso, a linguagem figura-se como ato social, livrando-se da reificação.

“Consideração do poema” figura o ato poético segundo perspectivas múltiplas, cuja justaposição compõe uma espécie de retrato multifacetado. Neste retrato, o discurso se revela como um tecido em que as pessoas e os elementos lingüísticos entrecruzam-se.

Trata-se de um poema feito de contradições. Cada parte do poema figura um aspecto da linguagem, recusado como sentido pré-estabelecido e refeito em sua capacidade significante. Como recusa, o aspecto figurado comporta uma dimensão intransitiva, porque representa o estado de reificação, em que o sentido não resulta da necessidade expressiva, mas de uma lógica exterior, mecânica, em que o significado vem previamente estabelecido. Ao figurar esse estado intransitivo, no entanto, o aspecto lingüístico aparece como um fragmento significante, que no contexto dialogal do poema acaba por expressar um novo significado, orgânico, ao sofrer a intervenção da expressividade subjetiva. O plano em que se dá a recusa dos significados mecânicos é o da linearidade lógico-analítica, sincrônico, enquanto o plano da ressignificação e da organicidade é o dos entrecruzamentos analógicos e dialógicos, diacrônicos. As intersecções entre sincronia e diacronia resultam na síntese expressiva. 
Da intransitividade reificante à transitividade significante, o poema figura a si próprio como trabalho social, e, por isso, remete à temporalidade do cotidiano. O cotidiano capitalista efetua a separação entre significantes e significados, para que a divisão social do trabalho se intensifique e a mercantilização das relações sociais promova a expropriação da riqueza produzida na forma do lucro ${ }^{70}$. Essa dimensão alienante vem figurada no poema como forma de promover sua transfiguração. Esse é o sentido de "Consideração do poema”. Ao adotar a perspectiva do cotidiano, o poema figura a separação entre significantes e significados, mas a subjetividade lírica promove o trânsito entre as necessidades interiores e as possibilidades exteriores, mediado pela linguagem, que se refaz. A liberdade lingüística resulta do trânsito cognitivo entre a volição subjetiva e o contexto objetivo; é, portanto, transitiva.

A pluralidade estética do poema é a sua dimensão profundamente engajada. A eficácia artística do poema resulta do diálogo competente entre estética e política. Não é possível entender essas duas dimensões como antinômicas; a antinomia está no empobrecimento dos significados humanos pela mercantilização das relações sociais. A poesia de Drummond cria um sistema simbólico integrativo que revela, como experiência a um tempo afetiva e intelectiva, esse empobrecimento das significações, ao mesmo tempo que o supera.

Nem a estética é tomada como sincronia absoluta, nem a política é tomada como diacronia absoluta. No poema, embora a linearidade esteja presente, a multiplicação de perspectivas cria um efeito de profundidade dialogal em que estética e política são aspectos de um real mais amplo, que comporta e integra as mais diversas realidades. Estão presentes as questões artísticas e sócio-políticas imediatas, como tema e também como forma. Percebe-se o contexto imediato do Modernismo, do varguismo e do embate mundial, vistos do prisma revolucionário individual. Mas o engajamento só tem eficácia porque o entendimento artístico e político transcende a conjuntura imediata, na medida em que investe na linguagem como mediação e na subjetividade lírica e cotidiana como escala. A percepção profunda da historicidade em Drummond não está apenas no tomar partido, e sim no entendimento de que o ponto de vista não dispensa a visão em profundidade nem o sentimento da transformação, consciente ou inconsciente, voluntária ou involuntária, de todo modo inevitável.

\footnotetext{
${ }^{70}$ Lefebvre, op. cit.
} 
De certa maneira, este poema apresenta o livro a que pertence, tanto pelo prisma das suas unidades, os poemas, quanto em seu conjunto mais amplo. Na medida em que o sistema simbólico drummondiano instaura o processo das “inquietudes”, e não um conjunto temático-formal, a relação entre subjetividade e exterioridade instaura um movimento expressivo cujo sentido, em $A$ rosa do povo, é a redenção transitiva do indivíduo, isto é, da pessoa como um ser relacional. A pluralidade de estilos e de temas, inesgotável, decorre desse movimento cognitivo do eu em direção a si mesmo ou em direção ao mundo. Se predomina a confissão subjetiva da dor, sempre marcada pelo gauchismo drummondiano, ou se a ênfase se encontra na exterioridade dos eventos, a perspectiva é sempre a da redenção subjetiva por intermédio da linguagem, daí a presença maior ou menor da metalinguagem em todos os poemas. É no plano da expressão que ocorre a transfiguração dos sentidos, desde os mais subjetivos até os mais exteriores. Esse plano, embora guarde um aspecto de sincronia, não se desvencilha, em momento nenhum, da preocupação transitiva com a redenção do indivíduo, em sua dimensão necessariamente relacional, que comporta a memória e outras formas diacrônicas.

A intensa coerência textual de "Consideração do poema”, realizada paradoxalmente pela multiplicidade de recursos expressivos, antecipa o sentido da multiplicidade temático-formal de A rosa do povo, e cada poema desse livro contém, diluída ou concentrada, a reflexão metalingüística. Essa é a coerência da coletânea: um engajamento cujo sentido estético tem dimensão política, e cujo sentido político tem dimensão estética. A chamada "lírica de guerra", a "lírica familiar", a "lírica do cotidiano", os poemas com significado aparentemente hermético, os metapoemas, a interlocução entre o poeta e outros artistas, todos os poemas e os grupos que se possam formar, segundo a tônica temática e/ou formal (sempre provisórios, intercambiáveis) todos eles evocam uns aos outros, porque sua natureza é dialogal, graças à consciência lingüística que carregam. Os significados adquiridos pelos poemas apresentam a marca da subjetividade lírica gauche, cujo sentido estético-político guarda a escala individual e cotidiana contra a reificação, e embora não se reduza à conjuntura imediata da escrita ou da leitura, comportam-na, de tal modo que o contexto é parte integrante do texto. 
CAPÍTULO 2

PROCURA 


\section{CAPÍTULO 2 - Procura}

\section{PROCURA DA POESIA}

1. Não faças versos sobre acontecimentos.

2. $\quad$ Não há criação nem morte perante a poesia.

3. Diante dela, a vida é um sol estático,

4. $\quad$ não aquece nem ilumina.

5. As afinidades, os aniversários, os incidentes pessoais não contam.

6. Não faças poesia com o corpo,

7. esse excelente, completo e confortável corpo, tão infenso à efusão lírica.

8. Tua gota de bile, tua careta de gozo ou de dor no escuro

9. são indiferentes.

10. Nem me reveles teus sentimentos,

11. que se prevalecem do equívoco e tentam a longa viagem.

12. O que pensas e sentes, isso ainda não é poesia.

13. Não cantes tua cidade, deixa-a em paz.

14. O canto não é o movimento das máquinas nem o segredo das casas.

15. Não é música ouvida de passagem; rumor do mar nas ruas junto à linha de

16. O canto não é a natureza

[espuma.

17. nem os homens em sociedade.

18. Para ele, chuva e noite, fadiga e esperança nada significam.

19. A poesia (não tires poesia das coisas)

20. elide sujeito e objeto.

21. Não dramatizes, não invoques,

22. não indagues. Não percas tempo em mentir.

23. Não te aborreças.

24. Teu iate de marfim, teu sapato de diamante,

25. vossas mazurcas e abusões, vossos esqueletos de família

26. desaparecem na curva do tempo, é algo imprestável.

27. Não recomponhas

28. tua sepultada e merencória infância.

29. osciles entre o espelho e a

30. memória em dissipação.

31. Que se dissipou, não era poesia.

32. Que se partiu, cristal não era. 
33. Penetra surdamente no reino das palavras.

34. Lá estão os poemas que esperam ser escritos.

35 Estão paralisados, mas não há desespero,

36. há calma e frescura na superfície intata.

37. Ei-los sós e mudos, em estado de dicionário.

38. Convive com teus poemas, antes de escrevê-los.

39. Tem paciência, se obscuros. Calma, se te provocam.

40. Espera que cada um se realize e consume

41. com seu poder de palavra

42. e seu poder de silêncio.

43. Não forces o poema a desprender-se do limbo.

44. Não colhas no chão o poema que se perdeu.

45. Não adules o poema. Aceita-o

46. como ele aceitará sua forma definitiva e concentrada

47. no espaço.

48. Chega mais perto e contempla as palavras.

49. Cada uma

50. tem mil faces secretas sob a face neutra

51. e te pergunta, sem interesse pela resposta,

52. pobre ou terrível, que lhe deres:

53. Trouxeste a chave?

54. Repara:

55. ermas de melodia e conceito

56. elas se refugiaram na noite, as palavras.

57. Ainda úmidas e impregnadas de sono,

58. rolam num rio difícil e se transformam em desprezo. 
Antonio Candido assim define a poética drummondiana entre 1935 e 1959:

Para ele [o poeta], a experiência não é autêntica em si, mas na medida em que pode ser refeita no universo do verbo. A idéia só existe como palavra, porque só recebe vida, isto é, significado, graças à escolha de uma palavra que a designa e à posição desta na estrutura do poema. O trabalho poético produz uma espécie de volta ou refluxo da palavra sobre a idéia, que então ganha uma segunda natureza, uma segunda inteligibilidade. Tanto assim, que o poema é geralmente feito com o lugar-comum (...). Nas mãos do poeta o lugar- comum se torna revelação, graças à palavra na qual se encarnou.

O trabalho necessário a isto é grande parte do que chamamos inspiração. Consiste na capacidade de manipular as palavras neutras, "em estado de dicionário" (que podem servir para compor uma frase técnica, uma indicação prática ou um verso) e quebrar o seu estado de neutralidade pelo discernimento do sentido que adquirem quando combinadas, segundo uma sintaxe especial. Inicialmente, é preciso rejeitar os sistemas convencionais, que limitam e mesmo esterilizam a descoberta dos sentidos possíveis.

(...)

Trata-se da decisão de usar a palavra com o senso das suas relações umas com as outras, pois a arte do poeta é por excelência a de ordenar estruturas; o tipo escolhido para associar os vocábulos (talvez o "desenho no céu livre”) é que transforma o lugar-comum em revelação. ${ }^{71}$

A leitura de Iumna Simon, diferentemente, propõe que a especificidade da poética drummondiana, ao menos em A rosa do povo, decorre de uma tensão bipolar entre a "abertura do discurso à comunicação" e um oposto "fechamento" às referências extra-lingüísticas. Seriam exemplares, nesses termos, os dois primeiros poemas de $A$ rosa do povo. O primeiro “Consideração do poema” consistiria numa exortação ao engajamento estético nas questões político-sociais, ao passo que "Procura da poesia”, o segundo, configuraria, não propriamente uma contradição, mas uma antinomia ${ }^{72}$, frente à exortação inicial, porque negaria a validade do poema como assunto, restringindo-o às práticas lingüísticas auto-referentes.

\footnotetext{
71 Antonio CANDIDO, "Inquietudes na poesia de Drummond”, in Vários escritos, p. 140.

72 "Contradição" e "antinomia", em princípio, significam o mesmo: a oposição entre termos, idéias ou valores. No entanto, o pensamento cartesiano expressa a contradição pelo termo "antinomia", porque não prevê que os contrários possam enfrentar-se e provocar transformações recíprocas, enquanto o pensamento dialético, diferentemente, se serve da contradição como um instrumento, não apenas válido, mas epistemologicamente necessário. O pensamento dialético é melhor expresso pelo termo "contradição", e para os seus fins o termo "antinomia" é inadequado, visto que encerra a idéia de opostos que se anulam, e não se complementam, nem provocam modificações recíprocas ao enfrentar-se.
} 
As aporias que cercam o "canto" engajado de A Rosa do Povo atingem o limite supremo da negação com a radicalidade da proposta de "Procura da Poesia”: o poema como objeto de palavras. Negação da experiência poética praticada nesta obra e da poesia realizada até então.

Não é por acaso que o poema é o segundo do livro. O poeta faz com que sua opção pelo engajamento - o apelo à prosa, ao discursivo, ao risco da comunicação, enfim - seja antecipada pela marca de sua aguda consciência artística, a mostrar que a opção é deliberada e consciente de seu próprio risco. Consciente mas não tranqüila, pois alternam-se e superpõem-se momentos de crença e descrença na viabilidade dessa prática, apelo à memória, ao sonho, ao passado $^{73}$. Razão por que explodem, no livro de 45, as grandes tensões da poesia de Drummond: nem a prática da poesia participante se faz tranqüilamente - questiona-se a cada passo - nem a recusa a ela é isenta de angústia, dada a necessidade de o poeta situar-se com relação à História ${ }^{74}$.

Sobretudo porque atravessa essas tensões, criticando-as enquanto reflexão e prática, o rigor da proposta contida em "Procura da Posa": a palavra como único e exclusivo material do poema, não como instrumento para a transmissão de idéias, sendo "eu” (função emotiva), da poesia de assunto (função referencial) e da poesia de invocação (função conativa) - funções que aparecem conjugadas na prática poética de A Rosa do Povo. ${ }^{75}$

"Procura da poesia" é uma proposta avessa à vontade catártica de expressão através do "canto". Do universo das significações ("contar" o indivíduo e o mundo através do "canto") ao universo das formas (elidir "sujeito e objeto" através da supremacia da forma-palavra e silêncio). Da palavra"signo" à palavra- "coisa". Da poesia-expressão à poesia-construção. Da penetração na vida presente à penetração no "reino das palavras". Do "risco" ao acerto: do "canto ardoroso" ao "cristal frio".

Considerando-se essa passagem de uma forma de engajamento (políticosocial) a outra (o engajamento com as palavras), pode parecer, à primeira vista, que o poema está desligado do sistema de valores poético de A Rosa do Povo, sobretudo no nível da operação metalingüística. Afinal, esta se realiza

\footnotetext{
73 "Memória, sonho e passado" participam da complexidade própria ao tempo presente (em sua dimensão cotidiana não reificada) e à subjetividade, não configurando, de modo nenhum, antinomias em relação ao engajamento drummondiano (ao contrário: o engajamento socialista de Drummond tem como proposta a integração de esferas que se apresentam ideologicamente cindidas na lógica reificante da produção capitalista, mas que são de fato complementares). As contradições da poética drummondiana (pelo menos em $A$ rosa do povo) estão em outro lugar: na figuração (temática e/ou formal) das relações sociais mercantilizadas do capitalismo, a cujo fetichismo a poética contrapõe a transitividade entre o simbólico e o concreto, mediado pela subjetividade e pela linguagem. Essa é a verdadeira contradição na poética de $A$ rosa do povo. Como se trata de uma poética cuja coerência profunda são as "inquietudes" de natureza processual e subjetiva, os sujeitos do discurso poético e os seus elementos são repensados na experiência lingüística, que explicita a si mesma em diversos (mas complementares) níveis: na dimensão sincrônica da linguagem, mas, também, na dimensão diacrônica das relações sociais, ambas complementares.

${ }^{74} \mathrm{O}$ ensaio "Inquietudes na poética de Drummond", de Antonio CANDIDO, propõe que as angústias do eu lírico drummondiano quanto à figuração da própria subjetividade ou do contato com o mundo exterior resolvem-se no plano da expressão, tendo se originado no desejo subjetivo de redimir o eu e o mundo “tortos”, percebidos em seus vínculos complexos. Desta perspectiva, o plano da expressão efetua a síntese das contradições entre eu e mundo, e, portanto, com ser sintética, não funda uma nova contradição, não pelo menos em termos de "antinomia".

${ }^{75}$ Iumna SIMON, op. cit., p. 147.
} 
para negar a prática de uma linguagem referencial, centrada nos "acontecimentos" do mundo objetivo ou subjetivo. Entretanto (e procuraremos demonstrá-lo no decorrer da análise), o compromisso com as palavras não implica a "repulsa violenta" do compromisso político-social, como querem fazer alguns críticos de Drummond (...). Estas posições decorrem do fato de não se levar em conta o movimento essencialmente dialético da "procura": a síntese emerge do jogo de negações e afirmações que sustenta o poema, mantendo-se tensa, por conseguinte, aquela margem de desacordo entre autonomia $e$ comunicação que é a grande marca do processo poético de A Rosa do Povo. ${ }^{76}$

Esta pesquisa não entende os dois primeiros poemas de $A$ rosa do povo dessa maneira. "Consideração do poema” representa a criação poética como ato social integrativo, que supera a dissociação mecânica entre significante e significado. Muito embora em alguns momentos o plano denotativo figure a dissociação entre as práticas concretas e as práticas simbólicas, o plano conotativo transfigura esse estado de alienação, imprimindo-lhe um acentuado caráter de subjetividade e de volição, e restabelecendo a complexidade transitiva entre os níveis da produção e da reprodução da vida material.

Enquanto a temática de "Consideração do poema" é o trânsito entre a(s) subjetividade(s) e o mundo objetivo, mediado pela linguagem, pela volição e pela cognição, o tema de "Procura da poesia” é a capacidade significante da linguagem diante do ato criativo. Vistos dessa perspectiva, não há incoerência, ou antinomia, entre os dois poemas, senão complementaridade de perspectivas. Enquanto o primeiro representa a linguagem simultaneamente como ato significativo e como significado social, o segundo tematiza a capacidade significante da linguagem - mas não nega sua dimensão social (muito embora não a reduza aos significados costumeiros). Se há contradição em A rosa do povo (há, e múltiplas), ela não se funda na dicotomia entre linguagem e práticas sociais, mesmo porque a linguagem conota-se como prática social. A contradição está entre as práticas reificadas e a necessidade / desejo de superá-las.

\footnotetext{
${ }^{76}$ Idem, ibidem, p. 151-152
} 
"Procura da poesia” apresenta uma estrutura complementar à de “Consideração do poema”, o que já se intui pelo exame dos títulos, expressivamente paralelos ${ }^{77}$. No primeiro, “considera-se”, enquanto no segundo “procura-se”, de modo que as essências das duas experiências poéticas enunciadas assemelham-se. A substância de cada poema, o seu nome, é uma ação, aparentemente mais reflexiva no primeiro que no segundo, de todo modo transitiva (note-se que os complementos nominais são, de fato, objetos diretos dos atos enunciados).

A criação artística é o objeto dos dois textos, ainda que as perspectivas sejam diferentes: no primeiro, trata-se de “poema”, enquanto no segundo trata-se de "poesia”. O “poema” é uma forma de expressão efetiva, enquanto a “poesia” é uma forma de expressão potencial, ou um modo de conceber a experiência. Desse modo, a interioridade reflexiva de “consideração” direciona-se à exterioridade do “poema”, na medida em que se dirige a um objeto concreto, enquanto a exterioridade de "procurar" adquire uma dimensão abstrata e subjetiva, porque se dirige a uma concepção.

Sendo assim, o trânsito entre subjetividade e exterioridade se enuncia tanto em um poema quanto em outro, muito embora com diferentes pontos de partida e de chegada. De todo modo, por mais que os significados possam divergir entre si, as formas significantes demonstram-se expressivamente paralelas. Haverá, então, níveis concorrentes, e não apenas níveis dissonantes, que se tornam sobretudo complementares.

Não apenas o paralelismo dos títulos, mas também a posição consecutiva dos poemas na obra apontam para uma dimensão dialogal e complementar, que pode

\footnotetext{
${ }^{77}$ Não apenas os títulos são estruturas paralelas: os dois poemas comportam 7 estrofes, como o primeiro poema do primeiro livro de Drummond ("Poema de sete faces", publicado em Alguma poesia). Esse paralelismo revela-se ainda mais profundo, na medida em que os dois poemas de $A$ rosa do povo, em que pese a diferença de problemáticas, empregam uma diversidade de recursos expressivos, pluralidade de tons, de falas, de métricas, de ritmos, de sonoridades e de figuras, unificadas, contudo, pelo lirismo, em suas "inquietudes".
} 
comportar níveis de oposição, mas não de antinomia. Há, certamente, um aspecto opositivo entre as identidades que cada poema constrói: o primeiro, retratando a intersecção entre autor, público e obra, e o segundo, demarcando os limites dos sujeitos no dinamismo da linguagem. Contudo, a alteridade que esses processos identitários constroem tem a natureza do complemento, e não da exclusão. Ambos os processos se integram a uma preocupação mais ampla que os transcende, qual seja, a de afirmar a liberdade como princípio transitivo entre a subjetividade e a exterioridade.

Essa liberdade não implica a mera desfiguração dos vínculos entre o sujeito e o que lhe é exterior (seja o mundo, sejam outras subjetividades, seja a própria linguagem); ao contrário, a liberdade consiste em desfazer os vínculos costumeiros para refazê-los segundo as necessidades subjetivas, não tomadas em si, mas situadas como parte dum real mais amplo. Para tanto, a subjetividade deve servir-se da linguagem como meio desprovido das determinações preexistentes (subjetivas ou objetivas, não importa). A capacidade dos recursos lingüísticos é pré-condição para que se restaurem os vínculos entre a subjetividade e a exterioridade. Se os vínculos entre eu e mundo são refeitos e, para isso, a linguagem atua como fator necessário de mediação, então é de transitividade que se trata, e não de intransitividade.

Desvincular as "palavras” (metonímia do nível significante da linguagem) da carga reificante que os seus sentidos costumeiros comportam é apenas um dos movimentos de "Procura da poesia", e o que mais ênfase recebe no plano da denotação. No entanto, esse movimento não está completo nem suficiente em si mesmo: complementa-se quando as "palavras" recuperam sua capacidade significante. (Note-se que quando as "palavras" superam o estatuto de registro imediato da exterioridade, ou de objetos da linguagem, à qual metonimicamente equivalem, então elas passam a figurar-se antropomórficas.) Isto se faz não apenas no nível denotativo, mas sobretudo no plano da conotação, e requer a figuração de todos os aspectos do discurso poético (o falante, o ouvinte, a obra e o contexto), e não exclusivamente a dimensão sincrônica da linguagem.

Como o poema anterior, este também figura os sujeitos do discurso, marcando com precisão seus lugares, e também figura a obra e o seu contexto de produção, além de promover um deslocamento completo desses significados, muito embora noutra direção e com outros recursos. Enquanto no primeiro poema a relação entre os sujeitos do discurso fez-se predominantemente por empatia e por deslocamentos metonímicos, nesse outro a relação se faz por deslocamentos de natureza primeiramente irônica, 
depois alegórica, e, por fim, sinestésicas. Ainda assim, ambos têm, na linguagem (evocada por metonímia: “palavras”, “versos”, “poema”, “canto”), o ponto de partida e de chegada.

\section{4}

Em "Procura da poesia” encontram-se figurados o eu e o tu do discurso. Figurase, também, o próprio discurso poético, como princípio mas também como ato. O cerne do poema, no entanto, não é o plano dessas figurações, mas o deslocamento dos personagens, o que confere à figuração do espaço (o “contexto”) um importante poder imagético.

Esse processo apresenta dois momentos. No primeiro, recursos como a paródia e a ironia provocam inversões entre as perspectivas de emissor e receptor. No segundo momento, emissor e receptor comungam, já não mais assimétricos, a experiência da linguagem, que não se faz absoluta mas, ao contrário, situa-se num determinado contexto e a partir dum determinado ponto de vista (comum, agora, a falante e ouvinte).

Esse é um poema interlocutório desde o plano do enunciado. A presença do "eu” vem marcada, muito embora o lugar do "tu” seja fundamental.

A fala do "eu” é uma apropriação de elementos discursivos do "tu”, e se refere a uma terceira figura: a "poesia". Na leitura imediata, encontra-se o discurso que o "eu" dirige ao "tu”, mas nessa fala, implícito, percebe-se o discurso do "tu”, não em sua integridade, mas em aspectos temático-formais que o "eu” seleciona, desfigurando-os através da paródia.

A prática discursiva do "tu” e a prática discursiva do “eu” são, portanto, especulares, reflexivas, e conduzem a uma terceira prática. A prática do "tu” vem (des)figurada pelo riso sardônico do “eu”, na forma de caricatura. Essa caricatura tem dois níveis: o do enunciado, discursivo, que define negativamente o que seja "poesia”, e 
o nível conotativo da prática formal, que forçosamente comporta o paradoxo de definir o que não é “poesia” pela prática do que se considera “poético”, e que é o próprio poema em sua "materialidade". Assim, o plano significante da forma não reitera necessariamente os significados denotados, porque configura uma terceira prática, que não é mais a do "tu” nem a do “eu”, e sim a perspectiva autoral, em que está o real sujeito do discurso, que não se deve confundir com as personae figuradas.

\section{6}

É possível encontrar significados no plano imediato do enunciado, mas é necessário entender o adensamento do discurso pela mediação significante do plano conotativo, que transfigura os significados prévios em novos significados, caso contrário corre-se o risco de tomar a significação "poética” (que é a prática lingüística ressignificante, indiscutível característica da poesia drummondiana) por significados “prosaicos” (que a paródia denuncia e ridiculariza - mas que não se aplica ao próprio poema). Esvaziar a "poesia” de “prosaísmo” é exatamente em que consiste a problemática de "Procura da poesia”, e esse fim se cumpre, paradoxalmente, pela figuração caricatural (mas poética) do "prosaico".

É possível especular sobre a prática discursiva do "tu” através do que a problemática denota, a saber, a "má poesia”, segundo critérios que se explicitam no próprio poema ${ }^{78}$. A “má poesia” são os “versos sobre acontecimentos”, tanto os de

\footnotetext{
${ }^{78}$ Inúmeros poemas de $A$ rosa do povo referem-se a práticas simbólicas "condenáveis" e/ ou "insuficientes":

"Consideração do poema" (que evoca e recusa determinadas convenções poéticas de caráter ornamental e convencional);

"O medo" (v. 47-50: "O medo, com sua física,/ tanto produz: carcereiros,/ edifícios, escritores,/ este poema; outras vidas.”);

"Nosso tempo" (v. 1-4: "Este é tempo de partido,/ tempo de homens partidos.// Em vão percorremos volumes,/ viajamos e nos colorimos.", v. 131: “a má poesia, o mau romance”, v. 163-174: "Há o pranto no teatro,/ no palco? no público? nas poltronas?/ há sobretudo o pranto no teatro,/ já tarde, já confuso,/ ele embacia as luzes, se engolfa no linóleo,/ vai minar nos armazéns, nos becos coloniais onde passeiam ratos noturnos, / vai molhar, na roça madura, o milho ondulante,/ e secar ao sol, em poça amarga./ E dentro do pranto minha face trocista,/ meu olho que ri e despreza,/ minha repugnância total por vosso lirismo deteriorado,/ que polui a essência mesma dos diamantes.");

"Passagem do ano" (v. 29-33: "O recurso de se embriagar./ O recurso da dança e do grito,/ o recurso da bola colorida,/ o recurso de Kant e da poesia,/ todos eles... e nenhum resolve.”);

"Uma hora e mais outra" (v. 36-42: "não a do cinema/ hora vagabunda/ onde se compensa,/ rosa em tecnicólor,/ a falta de amor,/ a falta de amor,/ A FALTA DE AMOR;”);

"Ontem” (v. 10-15: "Tudo foi breve/ e definitivo./ Eis está gravado// não no ar, em mim,/ que por minha vez/ escrevo, dissipo.”);
} 
natureza objetiva (a “cidade”, o “movimento das máquinas”, o “segredo das casas”, a “música ouvida de passagem; rumor do mar na rua junto à linha”, a "natureza”, “chuva e noite”, "os homens em sociedade”, “fadiga e esperança”, as “coisas”) como os de natureza subjetiva (que envolvem "o corpo, esse excelente, completo e confortável corpo, tão infenso à efusão lírica” e seus aspectos metonímicos: "tua gota de bile, tua careta de gozo ou de dor no escuro”, "teus sentimentos, que se prevalecem do equívoco e tentam a longa viagem”, “o que pensas e sentes”, e envolve também as propriedades materiais particulares: o "iate de marfim”, os "sapatos de diamante”, as práticas pessoais: "mazurcas e abusões” e a própria identidade: a "sepultada e merencória infância”, a "oscilação entre o espelho e a memória em dissipação”) 79 .

Todo o arco temático drummondiano, tanto o de A rosa do povo quanto o de poemas pregressos, cabe nestes campos semânticos denotados, o que parece configurar uma contradição, já que a persona do "poeta”, dessa maneira, condenaria a própria prática drummondiana. A sutileza, no entanto, está em que não se vetam os “acontecimentos” como matéria de "poesia” em si, mas a "fatura” de "versos sobre”.

"Versos” não são prerrogativa do "poético” na poesia drummondiana, o que já “Consideração do poema” sublinhara.

\section{Não rimarei a palavra sono \\ 2. com a incorrespondente palavra outono. \\ 3. Rimarei com a palavra carne} inatingível.");

"Fragilidade" (v. 1-2: "Este verso, apenas um arabesco/ em torno do elemento essencial -

"Anúncio da rosa" (v. 17-20: "Por preço tão vil mas peça, como direi, aurilavrada,/ não, é cruel existir em tempo assim filaucioso./ Injusto padecer exílio, pequenas cólicas cotidianas,/ oferecer-vos alta mercancia estelar e sofrer vossa irrisão."; v. 24-26: "Selarei, venda murcha, meu comércio incompreendido,/ pois jamais virão pedir-me, eu sei, o que de melhor se compôs na noite,/ e não há oito contos. Já não vejo amadores de rosa.");

"O mito" (v. 84-92: “(...) e Fulana// talvez dance no cassino/ ou, e será mais provável,/ talvez beije no Leblon,/ talvez se banhe na Cólquida;// talvez se pinte no espelho/ do táxi; talvez aplauda/ certa peça miserável/ num teatro barroco e louco;"; v. 145-152: "Sou eu, o poeta precário/ que fez de Fulana um mito,/ nutrindo-me de Petrarca,/ Ronsard, Camões e Capim;// que a sei embebida em leite,/ carne, tomate, ginástica,/ e lhe colo metafísicas,/ enigmas, causas primeiras.”);

"Versos à boca da noite" (v. 5: "Escreverei sonetos de madureza?") ;

"Carta a Stalingrado" (v. 9-12: "A poesia fugiu dos livros, agora está nos jornais./ Os telegramas de Moscou repetem Homero./ Mas Homero é velho. Os telegramas cantam um mundo novo/ que nós, na escuridão, ignorávamos.”);

"Canto ao homem do povo Charlie Chaplin" (v. 1-2: "Era preciso que um poeta brasileiro,/ não dos maiores, porém dos mais expostos à galhofa,", v. 21-24: "Bem sei que o discurso, acalanto burguês, não te envaidece,/ e costumas dormir enquanto os veementes inauguram estátua,/ e entre tantas palavras que como carros percorrem as ruas,/ só as mais humildes, de xingamento ou beijo, te penetram.”).

${ }^{79}$ É interessante notar como o conceito de "palavra-puxa-palavra", proposto por Othon Moacir GARCIA (in: Esfinge clara), explica estes campos semânticos e os seus desdobramentos, não só no plano do significado, mas também no plano da significação. No entanto, diferentemente do que ocorre em outros textos, esse movimento assume, no contexto específico de "Procura da poesia", um efeito de paródia. 
4. ou qualquer outra, que todas me convém.

Estes quatro primeiros versos do poema-poética iniciam A rosa do povo situando-a de chofre numa polissemia vertiginosa. Figura-se o microcosmo da linguagem como experiência subjetiva. O trabalho significante estabelece relações orgânicas entre aspectos do real, porque considera as necessidades do indivíduo diante do mundo. Essa figuração se faz por metonímia, na medida em que "rima” representa algo ainda maior do que aquilo que enuncia, e o faz como assunto mas, também, como prática. Como assunto, remete a escolhas lexicais, com vistas a promover homofonia em fins de verso. Como prática, envolve todos os recursos fundamentais do poema (sonoridade, metro, ritmo) para esvaziar a homofonia em fins de verso, aparentemente efetuada e denotativamente negada. Essa prática (a de “rimar”) de fato deixa no poema o significado convencional restrito para transformar-se em relações mais amplas e complexas, que servem antes à problemática que ao ornamento. Assim, o "verso" deixa de ser a unidade de significação do poema. A "rima” perde o caráter de convenção e ornato porque amplia as relações entre o léxico, o verso e demais elementos de significação, no sentido da problemática (qual seja, a capacidade de significação).

Essa primeira estrofe do primeiro poema de A rosa do povo evoca o primeiro poema publicado em livro por Drummond: o "Poema de sete faces”80.

21. Mundo mundo vasto mundo

22. se eu me chamasse Raimundo

23. seria uma rima, não seria uma solução.

24. Mundo mundo vasto mundo

25. mais vasto é o meu coração.

A problemática da "rima” transcende o "verso" como unidade significante do poema, conferindo-lhe capacidade de estabelecer relações de naturezas diversas. Essa transitividade não-linear da parte ao todo e do todo à parte, que se revela na leitura analítica do poema em seus aspectos intrínsecos e extrínsecos, verifica-se já na escolha lexical, que se faz com vistas à problemática. "Versos” e “rimas” são vocábulos que representam a criação poética já na linguagem costumeira. “Consideração do poema” e "Procura da poesia” servem-se dos significados costumeiros, mas não com vistas a reiterá-los, e sim no sentido de ressignificá-los. Com isso, se apropriam também do que

${ }^{80}$ O "Poema de sete faces", por sua vez, evoca a natureza multívoca de toda a obra de Drummond. Cf. Alcides VILLAÇA, Lendo poetas brasileiros, p. 1-74. 
não é “poético” como matéria de “poesia”, inserindo nos significados unívocos do diaa-dia uma significância polissêmica. Nesse sentido, não se pode argumentar que "Procura da poesia” seja um momento em que se exorta a práticas poéticas "hieráticas” em detrimento de práticas poéticas “demóticas”

"Fazer versos sobre acontecimentos" tem o sentido de transpor significados de contextos extra-lingüísticos para o texto de modo imediato, desconsiderando portanto a capacidade que a linguagem tem de mediar as relações entre o impulso volitivo, que se origina na percepção, e o mundo. O discurso do "tu" parece ingênuo, na medida em que não elabora nem sua percepção do mundo nem sua capacidade de (re)nomeá-lo, se é que sente isso como necessário.

\section{7}

Já o discurso do “eu” tem natureza paródica e aparentemente paradoxal. Ao praticar a paródia, toma como assunto o discurso alheio, desfigurando-o e tornando-o risível; mas, desse modo, acaba por tomar como assunto o que condena, que é a "poética do assunto" (“fazer versos sobre acontecimentos”). Dessa perspectiva, se o discurso do outro não é “poético”, tampouco é "poético” o seu próprio discurso, do ponto de vista de “fazer versos sobre acontecimentos". A sua "matéria de poesia” é também um “acontecimento”, algo que se coloca como exterior à poeticidade.

Se os "acontecimentos" em si, subjetivos ou objetivos, não configurassem "matéria de poesia”, a "poesia" seria realmente algo intransitivo, hermético, fechado sobre si próprio, antinomia da comunicação, algo exclusivamente significante. Consistiria em restringir a linguagem à metacognição, tornando-se a sua própria “matéria de poesia”, sem que houvesse outros vínculos discursivos. Mas não é disso que trata este poema. Nele, a “matéria de poesia” não se restringe à metacognição lingüística. Ele não consiste na defesa do discurso hermético, intransitivo, mas no contrário: em que a linguagem recupere a sua transitividade, que é a capacidade de

\footnotetext{
${ }^{81}$ Estes são conceitos empregados por Sérgio BUARQUE DE HOLANDA a propósito da reação crítica à publicação de Claro enigma, a partir de 195, em artigo supracitado ("Rebelião e convenção". In: Sônia BRAYNER (org.) Carlos Drummond de Andrade, p. 189).
} 
intermediar o diálogo entre os diversos sujeitos e o que lhes é exterior, restabelecendo a percepção como potência a um tempo intelectiva, afetiva e sensorial.

A figuração paródica que o "eu” faz do discurso do "tu” promove muito mais do que a referência a um "acontecimento"; promove o trânsito entre as perspectivas de quem emite o discurso e de quem o recebe. "Eu” e “tu” experimentam os papéis de emissor e receptor. Ambos se colocam diante da experiência poética, que se dirige do imediato ao mediato. Ambos praticam a figuração visando à expressividade, e ambos experimentam o distanciamento cognitivo do seu objeto com vistas a, paradoxalmente, reaproximar-se mais e melhor. Para tanto, é preciso que a “matéria de poesia” seja a própria “poesia”, em sua dimensão “concreta” (experienciável, perceptível, sensorial) de “poema”. A “poesia” personifica-se e, assim, se torna "matéria de poesia”, não como “assunto”, apenas, mas como experiência sensível e inteligível, “acontecimento” mediado pela linguagem num contexto propício.

A personificação de “poesia” é redutiva: figura por metonímia a imagem do discurso poético como “palavras”, partes que representam o todo. Do todo poético participam os sujeitos e os objetos lingüísticos, ressituados num determinado contexto e mediados pelos signos; “palavras” funcionam como representação de "signos”, um dos diversos elementos do discurso, capazes de atribuir significados por interação entre a necessidade subjetiva e o contexto objetivo. O poema só é eficaz porque figura os “signos” como parte necessariamente integrante de um todo orgânico.

A paródia e a ironia são os recursos que promovem o deslocamento dos papéis e dos lugares de “eu” e “tu”, de início assimétricos, hierárquicos, mas depois situados a partir de uma mesma perspectiva graças ao riso. É o riso a característica fundamental da primeira parte, e tem como efeito atribuir ao discurso sua dimensão transitiva, dialogal, transfiguradora. Mas este efeito de transfiguração se faz, paradoxalmente, pelo recurso à desfiguração (escárnio), que é o plano discursivo do “eu”, no primeiro momento.

O “eu” escarnece de toda a movimentação do “tu”, reduzindo-a à impotência, ao imobilismo, à insignificância. Parodiado e ironizado, o discurso grandiloqüente do "tu” humilha-se, rebaixa-se. Nesse sentido, a imagem do "sol estático” é expressiva, e se aproxima do "sol” bíblico do Eclesiastes, sob o qual a história é um "nihil”.

1. Que proveito tira o homem de todo o trabalho

2. com que se afadiga debaixo do sol?

3. Uma geração passa, outra lhe sucede,

4. enquanto a terra permanece sempre a mesma. 
5. O sol se levanta, o sol se deita,

6. apressando-se a voltar a seu lugar, donde novamente torna a nascer.

7. Dirigindo-se para o sul e voltando para o norte,

8. $\quad$ ora para cá, ora para lá vai soprando o vento,

9. para retomar novamente o seu curso.

10. Todos os rios correm para o mar,

11. e contudo o mar não transborda;

12. para onde os rios vão,

13. para lá tornam a ir.

14. Tudo é penoso,

15. difícil de o homem explicar.

16. A vista não se cansa de ver,

17. nem o ouvido se farta de ouvir.

18. O que foi, será;

19. o que aconteceu, acontecerá:

20. nada há de novo debaixo do sol.

21. Mesmo que se afirme:

22. “Olha, isto é novo",

23. eis que já aconteceu em outros tempos,

24. muito antes de nós.

25. Não ficou memória dos antepassados,

26. nem dos vindouros ficará lembrança

27. para os que vierem depois. ${ }^{82}$

Dessa perspectiva, pode parecer que o poema recusa a historicidade e qualquer experiência temporal diacrônica, como a memória, que comporta a perda e tudo o que “desaparece na curva do tempo, é algo imprestável.”

29. Não osciles entre o espelho e a

30. memória em dissipação.

31. Que se dissipou, não era poesia.

32. Que se partiu, cristal não era.

Não se deve, entretanto, tomar a perspectiva irônica do discurso como o significado final do poema, mas como um dos níveis de significação, cujo papel dentro da problemática (que é o que de fato preside o discurso drummondiano) consiste em construir uma outra temporalidade, que não o imediatismo de "versos feitos sobre os acontecimentos”.

A memória, em A rosa do povo, é uma forma de conhecimento fundamental para a percepção do tempo presente, desde que se explicite como construção; a memória reificada, que seleciona aspectos do passado como forma de desvinculá-lo da

${ }^{82}$ Eclesiastes, 1, 9. In: Bíblia Sagrada, p. 787. 
experiência presente e de permitir o evasionismo, é invariavelmente alvo da desfiguração drummondiana ${ }^{83}$. Drummond se serve da memória como uma forma de conhecimento do eu e do mundo, capaz de interferir e ressignificar a experiência presente, e não como um “tema”. A memória drummondiana não aliena, é parte integrante do presente, porque possibilita que os atos sejam mediados pela experiência, e não se esvaziem de possibilidades. Quando a figuração da memória sugere a inviabilidade de se estabelecer relações entre experiências passadas e o campo presente das possibilidades, o indivíduo se figura como escravo, ou autômato, objeto de um mecanismo que lhe impõe valores e procedimentos. A rosa do povo é uma obra da maturidade, isto é, de um presente pleno de experiência e, portanto, propício a escolhas - à liberdade. A persona do gauche marca o tempo e o espaço de onde fala (a maturidade), e por isso mesmo a sua temporalidade consiste tanto nos eventos contemporâneos quanto nos eventos internos. A memória, nessa obra, é uma perspectiva e uma forma de conhecimento; não é imediatamente um tema.

Porque a problemática consiste em afirmar a capacidade libertária, ou transitiva, de atribuir significados aos signos conforme relações volitivas entre subjetividade e exterioridade, então a sintaxe torna-se um campo expressivo fundamental. A construção

83 Cf. os poemas:
"Nosso tempo" (em especial, os versos 48-73: "E continuamos. É tempo de muletas./ Tempo de
mortos faladores / e velhas paralíticas, nostálgicas de bailado,/ mas ainda é tempo de viver e contar./ Certas
histórias não se perderam./ .../ Ó conta, velha preta, ó jornalista, poeta, pequeno historiador urbano,/ .../
Tudo tão difícil depois que vos calastes.../ E muitos de vós nunca se abriram.");
"Nos áureos tempos" (o poema evoca pateticamente a memória autobiográfica de Drummond e, ao
mesmo tempo, satiriza a idealização de aspectos do passado e da infância, reiterando a expressão-título em
estruturas anafóricas, assim produzindo um efeito de proximidade afetiva com paradoxal distanciamento
irônico);

"Ontem", "Fragilidade" e "O poeta escolhe o seu túmulo" (estes poemas figuram a precariedade da memória como representação, por meio duma metalinguagem onde o fluxo discursivo, temporal portanto, se espacializa em estruturas que são, respectivamente, tercetos, versos livres e um sonetilho; em todas elas, o recurso do "gauchismo" expressa, ao mesmo tempo, proximidade afetiva e distanciamento cognitivo);

"Assalto", "Resíduo", "Morte no avião", "Desfile", "Retrato de família", "Interpretação de dezembro", "Indicações", "Os últimos dias" (nestes poemas, a memória figura-se mais como construção temático-formal do que como assunto);

"Como um presente", "Rua da madrugada", "no País dos Andrades" (a persona do "filho", mais que representar apenas os conteúdos psíquicos do poeta Drummond, permite a experiência edipiana de exumar o superegóico "pai-coronel”, patriarca amado/odiado, emblema dum passado a um tempo individual e coletivo, “oprimindo como um pesadelo o cérebro dos vivos", na possível associação entre a frase de Marx no Dezoito Brumário e os versos 59-63 do primeiro poema: "É talvez um erro amarmos assim nossos parentes./ A identidade do sangue age como cadeia,/ fora melhor rompê-la. Procurar meus parentes na Ásia,/ onde o pão seja outro e não haja bens de família a preservar./ Por que ficar neste município, neste sobrenome?”; o poema "Onde há pouco falávamos", embora também evoque a experiência dos “Andrades”, não o faz pela proximidade patética, mas pelo distanciamento irônico);

"Versos à boca da noite", "América" (nestes poemas, os eventos internos e externos interseccionam-se vertiginosamente);

“Telegrama de Moscou" (v. 8-17) e "Mas viveremos" (v.53-56) (estes dois poemas, ao retratar os acontecimentos presentes, imaginam um tempo futuro em que a memória construída pacifique a dor presente). 
da paródia atribui às frases caricaturais uma perda de significância. Aparentemente, trata-se de um discurso explicativo, em que o conceito se desdobra com vistas à precisão. Entretanto, ao fim do processo, o que ocorre é o inverso: o esvaziamento do sentido, resultando numa forma caricata, inexpressiva.

A produção do significado parte de uma assimetria acentuada entre o "eu” e o “tu”. As falas do "tu” são escarnecidas por um “eu” que se coloca em situação de poder como forma de reduzir a fala do outro à impotência. Evidenciado sintaticamente como sujeito das orações principais, o "tu”, no entanto, torna-se objeto da violência praticada pelo “eu”, que esvazia as práticas alheias pela expressão reiterada do imobilismo niilista.

A violência do niilismo irônico retira dos atos lingüísticos do "tu” toda a sua substância, todo o seu significado, reduzindo-o a um caráter de ornamento, adjetivo, incapaz de expressividade. Os aspectos de fala do "tu”, enunciados e parodiados, equivalem ao lugar deste outro do discurso, reduzido de falante a ouvinte, de sujeito a objeto. O outro, de eloqüente, torna-se infantil, na medida em que a sua fala se esvazia de potência, porque nada pode dizer, ou significar.

Da primeira estrofe à quarta, cada oração principal inicia um desdobramento semântico pelas orações subseqüentes, em que o sujeito sintático deixa de ser o "tu” e dá lugar aos aspectos da sua fala parodiados. No primeiro verso da primeira estrofe, “versos sobre acontecimentos” particulariza o “fazer” atribuído ao “tu” (sujeito sintático do primeiro período) e esvaziado pelo "não”. Nos quatro versos seguintes, o que era predicado verbal (o objeto direto e seu qualificativo: "versos sobre acontecimentos”) desdobra-se na frase seguinte como sujeito, isto é, o campo semântico de "versos sobre acontecimentos” origina uma série de sujeitos sintáticos (“a vida”, “as afinidades, os aniversários, os incidentes pessoais”), que se tornam objetos semânticos do ridículo, de forma que o "tu" se vê reduzido a aspectos de sua fala parodiada, que se esvazia de significação por meio do riso sardônico, isto é, passa da condição de significados à condição reificada de insignificância.

Este processo de reificação pelo riso e pelo esvaziamento dos significados é uma constante pelas quatro primeiras estrofes. Ainda na primeira, o campo semântico de "poesia com o corpo" (predicado verbal no sexto verso) se desdobra em "tua gota de bile, tua careta de gozo ou de dor no escuro" (sujeito sintático), da mesma forma que o campo semântico de "teus sentimentos” (predicado verbal no décimo verso) gera "o que sentes e pensa, isso” (sujeito sintático). 
É importante notar que a relação entre o “eu” e o “tu” comporta o distanciamento crítico, mas esse movimento, paradoxalmente, termina por estreitar o vínculo entre os sujeitos da linguagem no curso do poema, em vez de separá-los, enquanto a relação entre eles e os seus próprios discursos deixa de ser imediata e mimética para se tornar algo também mais próximo, embora não mais imediato. Por isso, o tratamento do "tu” deixa a ambigüidade irônica da paródia entre a primeira e a quarta estrofes e se encaminha para “mais perto" (v. 48).

Da quinta estrofe em diante, o “eu” se dirige ao “tu” não mais pelo escárnio. Agora, ambos abandonam suas perspectivas assimétricas. O "tu” já não mais pratica a grandiloqüência, e o "eu” não mais pratica a paródia. Ambos experimentam a “descida” ao "reino das palavras", uma experiência fortemente sinestésica, em que se vivencia um contexto espácio-temporal próprio ao poético.

A “descida”, evidentemente, não assume um caráter de oposição ou antinomia em relação ao que seja “alto”. O “reino das palavras” não é simplesmente o “chão” (v. 44), no sentido da materialidade, do concreto, oposto ao "alto”, esfera do simbólico, do abstrato, do sublime, duma suposta idealidade livre das “impurezas" do "vulgar”, das aparências ilusórias. O “reino das palavras" não é nem o campo dos significados costumeiros nem o campo sublime do ideal; ele é o espaço-tempo da "convivência” (v. 38), isto é, da experiência compartilhada, mas duma perspectiva “menor”. É a esfera das sensações, da percepção, mas anterior aos significados consumados. Comporta a vida cotidiana, mas não no sentido reificado, insignificante, do dia-a-dia capitalista; ao contrário, é uma dimensão propícia para que os significados pré-estabelecidos se refaçam, se renovem, da mesma maneira que as forças biopsíquicas se renovam no “sono” (v. 57), à “noite” (v. 56). É um “estado de dicionário” avesso aos significados unívocos, e próprio à pluralidade de significados, ou, antes, à capacidade de significação. É o momento da "noite”, em que as formas não se encontram plenamente "solidificadas", podendo assumir diferentes conotações porque ainda guardam as propriedades fluidas do que é "líquido”, numa espécie de limiar entre o “sono” e a “vigília”. Nesse sentido, o "reino das palavras” não evoca o lugar judaico-cristão dos “céus”, que se opõe ao terreno-material (finito, portanto), mas um lugar mítico que participa da experiência vital concreta, real, muito embora esteja mais para a 
intemporalidade do inconsciente psicanalítico que para a existência cartesiana da consciência ocidental.

Embora a fala do "eu” guarde o tom imperativo em relação ao "tu”, esse tom deixa a negatividade sardônica no sentido de promover uma aproximação igualitária e sensorial entre o “eu”, o "tu” e a "linguagem”. Por sob o tempo verbal imperativo, abandona-se o distanciamento promovido entre o "tu" e sua fala, aparentemente próximos quando imediatos, no sentido de verdadeiramente aproximá-los, aparentemente separando sujeito e objeto de linguagem mas, na verdade, “elidindo-os” (isto é, suprimindo-os, eliminando esta separação mecânica entre quem representa e o que é representado, ao sujeitar o agente da fala à capacidade significante dos “objetos” da linguagem, os signos). Quem procurava usar a linguagem para falar de si, agora, passa a experimentar a linguagem como maneira de falar por si, modificando a si próprio e à sua relação com o mundo. O tempo e o espaço da produção de sentidos não é o tempo-espaço do utilitarismo cartesiano de causa-efeito, mas o da gratuidade, o da livre associação, o do paradoxo. As contradições que o signo comporta, “com seu poder de palavra e seu poder de silêncio" (v. 41-42), em vez de anular o movimento do "tu” num imobilismo niilista, faz com que este "chegue mais perto e contemple as palavras" (v. 48-49).

De “lá” (v. 34), o “reino das palavras”, líquido, noturno e onírico, torna-se algo tão sensorialmente próximo do "eu" e do "tu” que ambos podem vislumbrar as "mil faces secretas sob a face neutra” (v. 50) de “cada uma” ${ }^{84}$ (v. 49) das "palavras”, tornando-se interlocutores numa espécie de diálogo esfíngico, em que quem busca expressar-se ouve perguntas cujas respostas possíveis no imediato serão necessariamente “pobres ou terríveis” (v. 52), porque pressupõem que se estabeleça uma relação mediada pela “chave” (v. 53) e que não vise a “melodia e conceito” (v. 55) unívocos e pré-estabelecidos, mas plurais e possíveis. As sensações de “umidade” e de “sono” reforçam a sinestesia e a capacidade simbólica das "palavras”.

\footnotetext{
84 Notar que este verso 49, bastante contido, efetua formalmente a sensação sinestésica de proximidade sensorial, como "forma definitiva e concentrada no espaço" (v. 46-47), contraponto à verborragia de caráter ornamental da poética do "tu", de que o "eu" escarnece. Aqui, ao contrário dos efeitos adjetivos que a sintaxe das estrofes um a quatro construíra, ao definir negativamente o "poético", percebe-se uma forma substantiva, cujo adensamento lingüístico não necessariamente rompe com a capacidade referencial.
} 
Se a "poesia elide sujeito e objeto" (v. 19-20), isto não significa que "Procura da poesia “defenda o poema como “objeto de palavras”, mas o contrário: “elidir” significa suprimir ambas as polaridades, pela superação da crença positivista em alcançar de maneira “objetiva”, imediata, uma exterioridade absoluta, livre de interferências subjetivas, ou uma subjetividade absoluta, livre de interferências objetivas. A "poesia” (princípio significante) exige que o "poeta” (sujeito do discurso) “aceite” a exterioridade do "poema” (objeto lingüístico), do mesmo modo que "ele [o poema] aceitará a sua forma definitiva e concentrada/ no espaço.” (v. 46-47). Nesta imagem, suprime-se “sujeito” e “objeto”, porque ambos interferem mutuamente nas realidades próprias a cada um. Uma tal interferência mútua de realidades diversas, mas intercambiáveis, é profundamente transitiva, embora recuse a comunicação imediata.

Por sob o tom distanciado de conselho que a fala do "eu" assume, ao adotar as formas verbais do imperativo, existe um presente que guarda um aspecto de intemporalidade descritiva mas que, na verdade, promove uma experiência narrativa, denunciada por dois verbos, um no pretérito perfeito ("refugiaram") e outro no futuro (“aceitará”). Dessa maneira, a impessoalidade descritiva anterior das quatro primeiras estrofes (“não há criação nem morte perante a poesia”, v. 2) se transforma na identidade entre "eu" e "tu” diante do que era expressão imediata dos “acontecimentos” externos ou internos mas que, agora, se transforma num “outro”, em que os personagens se espelham e com quem dialogam. A personificação do "poema” nas "mil faces secretas sob a face neutra” de "cada uma” das "palavras” que o compõem não deixa de espelhar o gauchismo do "Poema de sete faces", em que aspectos auto e hetero, bio e bibliográficos se encontram, mas mediados pela cognição e pela multiplicidade de falas, tons e perspectivas.

Neste jogo de identidades e alteridades, não há "reflexos” imediatos, mas construção "reflexiva”. “Consideração do poema” e "Procura da poesia”, por caminhos diferentes, figuram a experiência poética como uma relação dinâmica, complexa e libertária entre diversos sujeitos e o contexto em que se inserem. Em nenhum momento, postula-se a separação antinômica entre arte e sociedade.

\footnotetext{
85 “As aporias que cercam o 'canto' engajado de $A$ Rosa do Povo atingem o limite supremo da negação com a radicalidade da proposta de "Procura da Poesia": o poema como objeto de palavras. Negação da experiência poética praticada nesta obra e da poesia realizada até então.” (Iumna SIMON, op. cit, p.147).
} 


\title{
CAPÍTULO 3
}

\author{
ANÚNCIO
}




\section{CAPÍTULO 3 - Anúncio}

Este terceiro capítulo retoma a hipótese de que a poética de A rosa do povo constrói um sistema simbólico de grande complexidade, com vistas a proporcionar uma experiência cognitiva (a um tempo afetiva e intelectual) que supere, por meio da linguagem, as limitações do campo simbólico diante do real concreto (estado de reificação). Esta é a verdadeira dimensão engajada da obra: a construção de um sistema simbólico, através da materialidade do poema (os signos lingüísticos), que incorpora conceitualmente aspectos problemáticos do contexto como forma de transfigurá-los, segundo os recursos analógicos e propriamente intuitivos que o fazer poético comporta. A coerência profunda da obra não se encontra com exclusividade nos aspectos formais, ou nos aspectos temáticos, visto que os mesmos não podem ser reduzidos nem a características de estilo nem a grupos de assuntos, porque o fundamento da obra de 1945 é a pluralidade. Nela, os temas e os estilos de tal modo se multiplicam e recombinam que qualquer tentativa de classificá-los resulta invariavelmente provisória, relativa - e precária. A poética drummondiana, que se serve da contradição como matéria-prima, reconhece-se em todas as suas múltiplas faces, mas não se reconhece em nenhuma delas quando abstraídas de seu contexto artístico ${ }^{86}$.

O sistema simbólico complexo que é a obra drummondiana, e que atinge a sua máxima pluralidade (e não por acaso) em $A$ rosa do povo ${ }^{87}$, encontra o seu núcleo gerador nas “inquietudes”, que são os deslocamentos da subjetividade pelas dimensões interiores e exteriores de eu e mundo, de tal modo imbricadas que a confissão subjetiva impregna-se das questões sociais e a poesia “engajada” trai uma intensa radicalidade lírica, isto porque o que move o processo subjetivo (ou gauchismo drummondiano) é o

\footnotetext{
${ }^{86}$ Cf. Alcides VILLAÇA, Lendo poetas brasileiros, p. 3-4.

${ }^{87}$ MERQUIOR (op. cit., p. 121-122) estabelece quatro períodos para refletir sobre aspectos estilísticos da obra drummondiana. "No segundo período (1940-1945) [o "meio-dia da escrita"], a escrita lírica de Drummond, chegada ao auge da sua mestria técnica, esboça uma separação entre o estilo mesclado e uma elocução re-'purificada'. (p. 244). John GLEDSON (in Poesia e poética de Carlos Drummond de Andrade) discorda dos critérios dessa periodização proposta por Merquior: "Primeiro, é necessário abandonar certa periodização convencional da poesia drummondiana em três etapas - a irônica, a social, a metafísica. (...) estas etapas sugerem uma classificação fácil de uma realidade complexa - há poemas que são irônicos, sociais e até "metafísicos" ao mesmo tempo!" (p. 12-13). "Ficamos mais desapontados no nível por assim dizer intermediário, e sobretudo no que diz respeito à diferenciação dos distintos períodos da poesia drummondiana [por Merquior]. Neste nível, parece-nos que o Stilmischung [conceito elaborado por Erich Auerbach e que se pode traduzir como "mescla estilística"] entra, sem dúvida, como meio de análise objetiva, mas também de julgamento, o que impede uma explicação adequada das mudanças que a poesia sofreu." (p. 15).
} 
desejo de redimir a um tempo o eu, integrante do mundo, e o mundo, que integra a interioridade do eu. As “inquietudes” servem-se da dimensão contraditória (mas sempre integrativa, nunca antinômica) da experiência poética processual, cuja síntese se faz no plano da expressão. Por isso, a metapoesia drummondiana é um campo privilegiado para se pensar a redução dos aspectos contextuais (subjetivos e / ou objetivos) à dinâmica textual, que é a sua dimensão engajada.

A metapoesia nega, de maneira complexa, os estados reificados do trabalho artístico, recusando qualquer antinomia entre arte e sociedade, quer no plano da forma, quer no plano do conteúdo. Para tanto, representa a reificação como “aporia” (como fragmentos significantes cujo significado esvaziou-se). Este plano, porém, nunca é simples mimese, ou registro figurativo de uma situação real, porque sempre se rearticula com outros níveis de significação do poema que, assim, transfiguram-se. Em síntese, a figuração da “aporia” torna-se objeto de alguma forma de distanciamento (através da ironia, da alegoria ou da paródia, entre outros recursos), e assim desfigura-se; mas esse primeiro movimento, apenas aparentemente lógico-discursivo, subverte-se num segundo momento, cujo caráter é analógico, e em que a “aporia” se vê transfigurada. Retoma-se, dessa forma, a transitividade entre eu e mundo, entre o real concreto e o real simbólico, entre os significantes e os significados, ou entre quaisquer outros pólos percebidos como contraditórios no âmbito das sociedades capitalistas, mas que guardam a natureza do complemento.

Isto se torna especialmente válido para o símbolo que dá título à coletânea. Trata-se da "flor”, multifacética, polissêmica, gauche: a “rosa do povo”, a “orquídea antieuclideana”, a "sete flores", o "ramo de flores absurdas mandado por via postal ao inventor dos jardins”, as “flores que tanto amas quando pisadas”, a “que furou o asfalto, o tédio, o nojo e o ódio”, o “algo indescritível”, os "lírios [que] não nascem da lei”, a “rosa de fogo” ou "aurora” etc. ${ }^{88}$ O símbolo de muitas faces, por vezes, assume o caráter provisório da alegoria, mas invariavelmente transfigura-se numa polissemia, em direção ao símbolo. Como recurso provisório para a representação de significados préestabelecidos, a “flor" desfigura-se, assumindo o significado da precariedade e da reificação; mas como possibilidade libertária de ressignificar o costumeiro, a “flor” é

\footnotetext{
88 As expressões foram recolhidas, respectivamente, nos seguintes poemas (todos de $A$ rosa do povo): "Mário de Andrade desce aos infernos", "Áporo", "Anúncio da rosa", "Canto ao homem do povo Charlie Chaplin" (as duas expressões consecutivas), "A flor e a náusea", "Carrego comigo", "Nosso tempo", "Mas viveremos" (as duas últimas expressões).
} 
sempre representação de relações orgânicas, de intermediações entre o signo lingüístico e uma pluralidade de significados possíveis, segundo contextos múltiplos.

O presente capítulo pretende demonstrar esta hipótese por meio da leitura analítica dos seguintes poemas: “Áporo”, “Anúncio da rosa” e “Mário de Andrade desce aos infernos”. 


\section{3.a. “Áporo”}

\section{ÁPORO}

1. Um inseto cava

2. cava sem alarme

3. perfurando a terra

4. sem achar escape.

5. Que fazer, exausto,

6. em país bloqueado,

7. $\quad$ enlace de noite

8. raiz e minério?

9. Eis que o labirinto

10. (oh razão, mistério)

11. presto se desata:

12. em verde, sozinha,

13. antieuclidiana,

14. uma orquídea forma-se. 
A leitura do poema realizada por Décio Pignatari ${ }^{89}$, em 1971, procurou ressaltar o seu caráter de inventividade "mallarmeana" ${ }^{90}$. Nesse sentido, identificou, nos aspectos “materiais” do poema, a transformação, como que mimética, do “áporo” (um inseto himenóptero da família dos cavadores) num tipo de orquídea (significado que o vocábulo também comporta), superando-se. dessa forma, a situação insolúvel, proposta no início (“áporo”, etimologicamente, significa “sem saída”).

Pignatari percebe que a partícula "se" percorre o sonetilho de maneira significativa, e representa a essência de “inseto", cuja etimologia deriva de "sec””, em razão das "secções” que caracterizam anatomicamente o corpo daqueles animais. A partícula "se" vem reiterada ou modificada ao longo do poema, provocando um isomorfismo entre o plano semântico e os planos gráfico e fônico, sob um elevado grau de inventividade. O recurso fundamental para tanto é o das aliterações.

Na primeira estrofe, que anuncia a situação aporética, o "se" reitera-se no primeiro e no segundo versos, oculta-se no terceiro e retorna no quarto verso, sob a

89 “Áporo (Um inseto semiótico)", in Contracomunicação.

90 Segundo Pignatari, o alto grau de inventividade poética presente em "Áporo", que o crítico julga positivamente, voltaria apenas com "Isto é aquilo", publicado em 1962 em Lição de coisas (ausência que ele e os outros concretistas julgaram negativamente): "Como o poema gera o seu próprio dicionário verbal e nãoverbal, antidiconário. Drummond tornaria a fazê-lo, muitos anos depois e em igual nível, com Isto é Aquilo. (...) Uma das peças de poesia mais perfeitas e mais criativas, em âmbito internacional e dentro de uma tradição do verso pós-Mallarmé.” (PIGNATARI, op. cit., p. 137).

Os pressupostos da sua crítica literária militante, a exemplo da que praticaram seus companheiros de movimento, terminam por estabelecer juízos de valor sobre outras poéticas de modo a legitimar as suas próprias práticas artísticas. Em "Drummond, mestre de coisas", por exemplo, Haroldo de Campos afirma, a respeito da publicação, em 1962, de Lição de coisas: “... o último livro de CDA é um livro que se coloca em cheio, e com alarde de recursos e experiências, na problemática da poesia brasileira (e/ou internacional) de vanguarda, perante a qual já se situaram, cada um por seu turno, com menor ou maior radicalidade, episódica ou definitivamente, poetas como Manuel Bandeira, Cassiano Ricardo, Edgard Braga. Referimo-nos especificamente às questões levantadas pelo movimento de poesia concreta e às suas demandas em prol de uma nova linguagem poética apta a refletir a civilização contemporânea, às quais CDA, sobre a omissão cômoda de muitos, soube enfrentar e replicar em termos de alta e personalíssima criação. Com isto não se está querendo fazer qualquer miúda reivindicação de possíveis áreas de influência ou contágio, pois antes, no caso, se poderia argumentar que, ao contrário, foi a poesia concreta que assumiu as consequêencias de certa linha da poemática drummondiana (aquela que o crítico Oliveira Bastos rastreou, à maneira de um 'continuum formal', de Oswald a Drummond e deste a João Cabral, num artigo publicado no dealbar do movimento) (...) Os acontecimentos voltaram a 'ofendê-lo' (é o que se lê na introdução do livro) e, sob o impacto deles, dissolveu-se feito uma bruma o ennui absenteísta de Claro enigma. A reabertura à 'matéria do presente', aos novos conteúdos do presente problemático e contundente, significou mais uma vez, neste poeta paradigmal, a insatisfação com o repertório formal fixado pela tradição e, pois, uma reabertura recíproca às novas formas provocadas por esse presente. Nisto sua poesia é isomórfica ao seu sentimento do mundo. (...) Várias coisas não contam e podem ser descartadas: certa poesia comemorativa e/ou memorial (inclusive uma esporádica recaída no soneto); certos poemas 'padrescos' que se salvam pelo fio fino do humor; alguma insistência no 'discurso maior'. Mas o que conta, além de numeroso, é, principalmente, fundamental.” (In: Metalinguagem \& outras metas, p. 50-55). 
dupla forma "se” / “es”. Na segunda estrofe, o quinto verso sublinha o obstáculo com as variantes "se” / “ex”, mas o sétimo verso, metade exata do sonetilho, assinala o início da metamorfose de “inseto” em “encete” (“EnlaCE de noiTE”). A terceira estrofe muda o percurso em direção à “orquídea”: o décimo primeiro verso (“prESto SE dESata”), que encerra a maior concentração da partícula "se” e de suas variantes, figura, “ideográfica” e “ideofonicamente", a metamorfose do animal (não por acaso, o termo "presto" serve como referência cifrada à prisão do secretário geral do Partido Comunista no Brasil, Luís Carlos Prestes, durante o Estado Novo). No penúltimo verso da última estrofe (“antiEUCLIDIAna”), a qualificação do termo metamórfico (“orquídea”) já contém, isomorficamente, uma referência, não só à flor, mas também ao seu caráter de imprevisibilidade, tão extraordinário quanto os termos “áporo”, “presto” e “antieuclidiana”. Por fim, no último verso, concretiza-se, na partícula “-se”, a imagem da metamorfose do inseto em orquídea. Essa engenhosidade magistral filia-se, segundo o crítico, à tradição poética mallarmeana, o que já o segundo verso do poema sugeriria (“seM ALARME”).

A inventividade do poema “Áporo”, que o crítico Décio Pignatari ressalta em sua leitura, indicaria, segundo a interpretação de Iumna Simon ${ }^{91}$, um caráter opositivo em relação à prática participante de A rosa do povo. Enquanto nos "poemas engajados" predominaria a "abertura do discurso ao fator novo da comunicação", no antinômico "bloco do fechamento", que se inicia com ”Áporo”, a “dominante” seria o "fechamento do discurso aos aspectos referenciais”, por conta do predomínio da “função poética”.

Ao bloco de poemas engajados, constituídos por "Notícias", "América", "Cidade Prevista", "Carta a Stalingrado", "Telegrama de Moscou", "Mas Viveremos", "Visão 1944" e "Com o Russo em Berlim”, contrapõe-se um bloco de 10 poemas de características bem diversas, tanto sob o ponto de vista da matéria, quanto dos procedimentos de construção.

Este bloco é introduzido na obra pelo poema “Áporo”, grau máximo de oposição à prática engajada, como o demonstra Décio Pignatari na brilhante análise que faz do texto. A esse poema seguem-se: "Ontem”, "Fragilidade", "O Poeta Escolhe seu Túmulo", "Vida Menor", "Campo, Chinês e Sono", "Episódio", "Nova Canção do Exílio", "Economia dos Mares Terrestres", "Equívoco".

Do ponto de vista do plano do conteúdo, tais peças, ao contrário daquele conjunto de poemas engajados - especialmente o bloco das "líricas de guerra" - apresentam uma considerável variabilidade temática, embora a tematização do tempo ocorra com certa freqüência. O que as identifica é o processo de

\footnotetext{
${ }^{91}$ Drummond, uma poética do risco, p. 171-188.
} 
realização: são as mais condensadas do livro e inscrevem-se no campo vetorial aberto pela experiência poética de "Uma Pedra no Meio do Caminho" [sic] (Alguma poesia), reencontrada e/ ou radicalizada em "cortes", verificáveis em toda a trajetória do poeta, até atingir "Isso é Aquilo" (Lição de Coisas) "poema-dicionário dos acasos da composição, a girar sobre si mesmo num eixo mallarmaico, sem dúvida alguma um dos pontos mais altos da atual poesia brasileira (...)", como afirma Haroldo de Campos. ${ }^{92}$

É bastante significativo que Iumna Simon retome a análise de Pignatari sem, no entanto, referir, em nenhum momento, a observação do crítico quanto à menção poética a Luís Carlos Prestes e ao Estado $\mathrm{Novo}^{93}$. Contudo, segundo pressupostos de investigação que não restrinjam a presença do contexto a aspectos exclusivamente "referenciais" (entendidos como aqueles que evocam denotativamente os eventos da conjuntura, à maneira “prosaica” de gêneros como a crônica), é possível considerar “Áporo” e os demais poemas do chamado "bloco do fechamento” como textos engajados, nos quais a suposta antinomia entre procedimentos "prosaicos" e procedimentos “poéticos” não faria sentido.

Talvez seja esta [a violência duma poesia que não procura ser agradável] uma das causas que dão ao seu verso o aspecto seco e antimelódico. Mas é preciso considerar também que a sua maestria é menos a de um versificador que a de um criador de imagens, expressões e seqüências, que se vinculam ao poder obscuro dos temas e geram diretamente a coerência total do poema, relegando quase para segundo plano o verso como uma unidade autônoma. Ele reduz de fato esta autonomia, submetendo-o a cortes que o bloqueiam, a ritmos que o destroncam, a distensões que o afogam em unidades mais amplas. Quando adota formas pré-fabricadas, em que o verso deve necessariamente sobressair, como o soneto, parece escorregar para certa frieza. Na verdade, com ele e Murilo Mendes o Modernismo brasileiro atingiu a superação do verso, permitindo manipular a expressão num espaço sem barreiras, onde o fluido mágico da poesia depende da figura total do poema, livremente construído, que ele entreviu na descida ao mundo das palavras. ${ }^{94}$

Segundo a leitura de Antonio Candido, os aspectos formais organizam-se em torno do "poder obscuro dos temas", entendidos "menos no sentido tradicional de assunto, do que no sentido específico da moderna psicologia literária: um núcleo

\footnotetext{
92 Idem, p. 174-175.

93 "Quanto a outros níveis do poema, o jogo fica aberto à interpretação - que nada pode acrescentar-lhe de essencial. Em todo caso, alguma coisa sempre conta saber que Áporo surge na coletânea de um Drummondápice, $A$ Rosa do Povo,1945, ano da agonia do nazifascismo e do Estado Novo ( "em país bloqueado"), ano da soltura de Luís Carlos Prestes ("presto se desata", ...), ano de todas as auroras. " (PIGNATARI, op.cit., p.137.)

94 Antonio CANDIDO, "Inquietudes na poética de Drummond”, in Vários escritos, p. 145 (grifo nosso).
} 
emocional a cuja volta se organiza a experiência poética”95, núcleo este que o intelectual conceitua como "inquietudes”. Das “inquietudes”, viriam tanto os poemas de caráter mais acentuadamente subjetivo quanto aqueles em que o engajamento nas questões político-sociais é evidente, sendo importante frisar que ambos os pólos contaminam-se, em vez de configurar antinomias, de tal modo que os poemas engajados resultam tão subjetivos quanto, por exemplo, a lírica familiar, em que há, também, uma dimensão engajada. A síntese entre esses pólos é o plano da forma, em que as tensões, derivadas da problemática subjetiva, transfiguram-se, de modo que não procede, deste ponto de vista, a antinomia entre forma e conteúdo.

É possível perceber em “Áporo”, como nos dois metapoemas que iniciam A rosa do povo, diversos planos de significação a concorrer para a construção dos significados. O recorte descontextualizado de um desses planos compromete a percepção da dinâmica processual entre significantes e significados. O “poder obscuro dos temas" parece organizar a engenhosidade do poema, de tal modo que os procedimentos irônicos estabelecem um movimento de inversão, ou subversão, dos aspectos que, de um outro ponto de vista, pareceriam centrais ao poema, mas que na verdade funcionam como procedimentos mediados. Elementos contextuais a que se faz menção (como o formalismo de caráter ornamental, a restrição ao pensar e ao expressar-se e o objetivismo), ao sofrer uma espécie de desfiguração paródica, transfiguram-se em significados contrários, o que já não é mais o plano da mimese, mas a sua superação.

Em “Áporo”, a dimensão formal parece exacerbar-se, concorrendo para um grau máximo de objetividade. A precisão quase "geométrica” dos versos, matematicamente recortados; a polissemia do termo “áporo”; o papel construtivo das aliterações; a configuração icônica a prevalecer sobre o aspecto semântico; todos esses recursos parecem reduzir a um mínimo o papel das subjetividades (tanto a do falante quanto a do ouvinte) em favor da mensagem propriamente dita, de tal modo que a inventividade “poética” se faria mais forte do que quaisquer outros aspectos do discurso.

\footnotetext{
${ }^{95}$ Idem, ibidem, p. 115.
} 
Entretanto, é o próprio Décio Pignatari quem observa a dimensão paródica que este sonetilho guarda em relação ao soneto ${ }^{96}$. Em lugar dos decassílabos, há, invariavelmente, redondilhas menores, e o esquema rítmico, entre o compasso binário e o ternário, sugeriria o compasso da valsa, em termos caricaturais ${ }^{97}$. É importante destacar essas considerações do crítico para compreender em que medida a organização dos aspectos significantes interfere na construção dos significados.

A caricatura do formalismo imprime um efeito irônico ao poema, na medida em que o significado conotativo resulta inverso em relação ao que os significantes denotam. O aspecto formalista do sonetilho, na verdade, subverte os significados convencionais que a forma fixa do soneto adquirira com o seu uso literário pelos parnasianos, durante a República Velha. Em lugar da afetação e do conservadorismo presentes nas concepções estéticas parnasianas (consagradas na prática do soneto decassílabo pelo "príncipe dos poetas” Olavo Bilac), tem-se o metro “neoclássico” cerrado ao meio, e transformado em redondilha menor, metro de sabor popular na tradição literária de língua portuguesa. Assim, o aparente equilíbrio matemático, a suposta simetria e o senso geométrico das proporções vêem-se subvertidos pelo que há de grotesco, paródico e, enfim, burlesco ${ }^{98}$.

Esse espírito de burla se reforça quando, para além do encantamento que provoca a maestria engenhosa dos elementos “ideográficos" e “ideofônicos", identificam-se rupturas com o racionalismo sugerido (que, no final das contas, dissolvese pelo escárnio). O esquema rítmico ternário, já em si caricatural de acordo com o contexto lingüístico do sonetilho, e que se verifica nos versos 1 a 5, 9 a 11, 13 e 14, transforma-se em binário nos versos 6 a 8 (em que se referencia, indubitavelmente, a

\footnotetext{
96 “A configuração ideogrâmica da macroestrutura externa se constitui em algo assim como um índice-ícone (tal uma impressão digital) da forma do soneto, parodiado por miniaturização, diria mesmo, por bonsaização, técnica nipônica para produzir árvores-anãs. Algo assim como um soneto de versos decassílabos rasgado ao meio longitudinalmente, para produzir um inseto-soneto de pentassílabos, dentro de uma lógica teorêmica Q. E. D. euclidiana, mas que acaba resultando numa antilógica, analógica, propriamente poética. A metalinguagem crítica, parodística, da configuração externa apresenta também certas correspondências simbólicas na estrutura interna, a saber, naquelas expressões do primeiro terceto que aludem à altiloqüência do pseudo-castiço: Eis que, Oh razãa, Presto. E não deixa de ser curioso o fato de INSETO ser um quaseanagrama de SONETO... A configuração ideogrâmica e a aliteração vertical contribuem para romper com a diacronia da estrutura do verso, impondo-lhe um parâmetro sincrônico.” PIGNATARI, op. cit., p. 135-136. 97 “... compassos de uma valsa surpreendente e irônica, mas plenamente isomórficos à denotação de enlace de noite / raiz e minério e que também pode funcionar como comentário de humor à forma do soneto." Idem,ibidem, p. 137

98 O "grotesco" neste poema, que é a referência ao mundo subterrâneo, escuro, "baixo", ao "ventre" da terra, associado ao efeito de paródia, parece configurar, em certa medida, um recurso a aspectos do "cômico", nos termos propostos por Mikhail BAKHTIN (in A cultura popular na Idade Média e no Renascimento, p. 51-123). Para ele, o conceito de "cultura cômica popular" remete à cosmovisão de grupos que se organizavam à margem, ou em confronto com as instituições hierárquicas desde as primeiras civilizações, adotando práticas culturais cujo sentido era o restabelecimento das relações orgânicas igualitárias e cujos recursos derivavam de variadas formas do riso carnavalesco, a que serviam as a paródia, os insultos, as referências ao baixo corporal e às imagens grotescas.
} 
situação totalitária e fascistóide do Estado Novo, aspecto sublinhado por inúmeros poemas da coletânea), e no decisivo verso 12 (que “descreve” atributos do já anunciado “desatamento do labirinto” na “narrativa” do verso 11).

Os termos inusitados “áporo”, “sem alarme”, “presto” e “antieuclidiana” destacam-se em meio à maior parte das escolhas lexicais, que não trazem em si significados imprevistos. “Áporo”, em “estado de dicionário”, tem como característica a polissemia. O seu significado mais imediato de "impasse" será invertido através da mediação que a problemática artística conceitual estabelece entre os demais significados, em princípio desconexos (“inseto” e “orquídea”) ${ }^{99}$. Não apenas os recursos sintagmáticos da narrativa, mas também a engenhosidade paradigmática (“isomórfica” em relação à "metamorfose”) estabelecerão relações imprevistas entre aqueles significados de natureza diversa. Uma tal desfiguração do sentido prévio (“impasse”) já aponta para sua transfiguração, de tal modo que o sentido último do poema não é o obstáculo (“aporia”), mas a sua superação. O poema desfigura a incomunicabilidade e a paralisia (intransitividade), com vistas a invertê-las, transfigurando-as - e isto já é transitividade (e não mais “aporia”).

O termo "sem alarme” é paradoxal, porque enuncia o silêncio, mas o faz de modo "alarmante”, uma vez que o emprego de "alarme” em lugar do mais comum “alarde”, ao contrário do que se enuncia, termina por chamar a atenção para a escolha lexical. Essas rupturas com as expectativas resultam num desafio à “aporia”, inicialmente colocada com o sentido de "incomunicabilidade” e de "silenciamento".

O termo “presto", além da referência fundamental (e apenas aparentemente críptica) à prisão de Luís Carlos Prestes, remete ao universo empolado de erudição e preciosismo da literatura parnasiana, alvo de escárnio pelo poema-caricatura. Esta forma de referir a censura, aparentemente acatando-a mas de fato ridicularizando-a, é o exato contrário da precariedade aporética que o plano denotativo da forma e do conteúdo enunciam: é a sua burla, é enunciar o “sem alarme” praticando-o “com alarde”. O que o poema parece aludir é, no final das contas, a sua força expressiva, porque, em vez de acatar a imposição do silêncio, torna-se denúncia e subversão. A dimensão formal da

\footnotetext{
99 A exemplo de "Consideração do poema" e de "Procura da poesia", "Áporo" recoloca a problemática metonímica da escolha das "palavras" de modo a que a volição e a cognição estabeleçam mediações entre os universos da subjetividade e da exterioridade, o que vem a configurar o aspecto central da poética drummondiana em $A$ rosa do povo. Essa característica enuncia-se em diversos momentos da coletânea. Vejamse os versos 222-223 de "Canto ao homem do povo Charlie Chaplin": "Ó palavras desmoralizadas, entretanto salvas, ditas de novo./ Poder da voz humana inventando novos vocábulos e dando sopro aos exaustos.”
} 
poesia drummondiana em $A$ rosa do povo é também engajamento político, além de engajamento estético.

O último termo inusitado (“antieuclidiana”), além da referência cifrada à orquídea (“euclidia”, segundo anota Pignatari) e da referência direta aos axiomas do geômetra grego, pode também referir-se a outro Euclides, que produziu literatura no período da República Velha e que sofreu influências (sem que se restringisse a elas) do pensamento conservador de então ${ }^{100}$. O positivismo e o determinismo geográfico de Euclides da Cunha, presentes de maneira ambígua no "relato" que o jornalista fez do massacre aos sertanejos de Canudos, e que se mostraram tão inadequados para apreender a "antilógica” sertaneja (do ponto de vista litorâneo e "europeizado" das “elites” republicanas, que Euclides termina por abandonar), também parecem tornar-se vítimas do escárnio: “(oh razão, mistério)”. O paradoxo está não apenas nos aspectos semânticos da "razão" (burguesa), que se quer "esclarecimento” em vez de "mistério", mas que, em termos de outras racionalidades (como a dos conselheiristas), apropria-se das contradições como matéria-prima da sua "antilógica"; o paradoxo também se evidencia na construção parentética, que poderia significar a contenção do pathos e do próprio “inseto” mas que, na verdade, expressam a inversão disso tudo: a acentuada subjetividade do eu que, nesse verso, evidencia a si própria (mediante o recurso drummondiano do gauchismo) e a transfiguração da “aporia” em liberdade, transitividade e comunicabilidade.

Esses significados que aparentemente se ocultam, como de resto o próprio sujeito do discurso, mas que na verdade mimetizam o "inseto cavador" porque “enterram-se” para melhor acompanhar a transfiguração metamórfica da personagem e, assim, explicitar-se (ou “vir à luz”), não se constituem arbitrários, quando se considera que há uma citação explícita duma obra de Lênin no quinto verso. A expressão "Que fazer” é o título de um livro escrito pelo revolucionário ${ }^{101}$. A linguagem aparentemente cifrada do poema é, na verdade, uma referência eficaz à conjuntura de escrita, não apenas porque incorpora à sua forma, como recurso paródico, a impossibilidade vigente

100 Observação sugerida por Sylvia Tamie Anan.

101 Este apontamento foi sugerido pela leitura de Vagner CAMILO, Drummond: da Rosa do Povo à Rosa das Trevas, p. 121: "O arsenal de que dispõe o sujeito lírico, portanto, de nada lhe serve para reagir ao estado nirvânico em que se encontra mergulhado, devido às razões enumeradas no encadeamento vertiginoso do período composto. Com isso, reafirma-se sua condição acuada pela indagação perplexa com que dá fecho ao poema ["Pequeno mistério policial ou A morte pela gramática", de Claro enigma, livro de 1951] - que repercutirá no restante deste e do livro seguinte como o cerne do conflito encenado nos versos: "Que Fazer?" Indagação que desde Lênin (que a empregou como título de conhecida obra) tem sido reiteradamente formulada por todo espírito participante, angustiado pela busca de caminhos alternativos àquele em que naufragaram suas esperanças." 
de livre expressão do pensamento, mas sobretudo porque não se restringe a essa forma alegórica de dizer as coisas, porque a etapa das alusões se encaminha na direção do símbolo.

O “inseto" se coloca no contexto alegórico do "país bloqueado", termo que, a alguns críticos, não é lícito restringir ao contexto do Estado $\mathrm{Novo}^{102}$, mas que a esta abordagem não só é possível como também é desejável levar em consideração, sob pena de perder-se de vista o engajamento que o poeta, queiram ou não queiram algumas interpretações, de fato pratica. Já o “percurso-orquídea”, assim como a problemática conceitual que organiza os aspectos “materiais" do poema e que se serve do riso para desfigurar certos sentidos e assim transfigurá-los, encaminha-se no sentido do símbolo, ampliando, em vez de restringir, as possibilidades de significados em torno da "flor".

O seu significado não é unívoco, o que já se percebe no estado de polissemia, “pré-poético”, costumeiro, em que a palavra “áporo” se encontra (“estado de dicionário”). As operações analógicas do poema tendem a tornar o seu sentido ainda mais amplo, na medida em que “áporo” funciona como persona em que o “eu”, mas também o "tu" do discurso, se ocultam, sob a forma da terceira pessoa, para acompanhar o seu processo metamórfico que termina por inverter a reificação de natureza “kafkiana”103. Esse recurso à aparente despersonalização, sob a capa da terceira pessoa (mas que, na verdade, intensifica a expressão lírica de estados subjetivos), e que se conceitua como gauchismo, é freqüente n’A rosa do povo. No poema que antecede “Áporo” (“Rola mundo”), há também o personagem “himenóptero cavador” mas representado sob a primeira do singular:
80. E vi toda a minha vida
81. contrair-se num inseto.
82. Seu complicado instrumento

\footnotetext{
102 Davi ARRIGUCCI Jr. comenta que o referido estudo de Pignatari "Sugere, ainda, sem crer que se possa com ela acrescentar algo de essencial, uma abertura à interpretação, entendendo por isso alusões referenciais a certos fatos histórico-políticos da década de 40 a que fragmentos do texto poderiam se prestar (como 'país bloqueado', relacionado como Estado Novo, ou 'presto se desata', com a libertação de Luiz Carlos Prestes...).. (op. cit., p. 78). E ainda: "A alegoria poderia se prestar então a uma tradução direta em fatos do momento histórico em que foi escrito o poema, quando não faltavam no cenário nacional e no internacional, fatores de opressão, como a ditadura militar de Vargas e Segunda Guerra Mundial. É nessa direção que se encaminham as alusões registradas por Pignatari em sua descrição indicativa, desconfiada, aliás, do próprio rumo e da eficácia de uma leitura nesse sentido. Para tentar interpretar, não é, entretanto, exatamente por aí que se deve buscar a passagem. Mais uma vez, é preciso procurar a articulação com o todo, ou seja, com a totalidade da construção - o enredo completo que é o poema enquanto mito verbal (...).” (idem, ibidem, p. 95).

103 Refere-se ao conto A metamorfose de Franz Kafka, escrito em 1912 e publicado em 1915, que narra a transformação da personagem principal num inseto repugnante, figurando assim a condição reificada na contemporaneidade.
} 
83. de vôo e de hibernação,

84. sua cólera zumbidora,

85. seu frágil bater de élitros,

86. seu brilho de pôr de tarde

87. e suas imundas patas...

Enquanto o plano denotativo (que, é importante reiterar, não é o significado final do poema) figura no poema "Rola mundo" a "aporia” que a personagem representa, o poema “Áporo”, ao contrário, já no plano denotativo, desfigura o impasse enunciado no sentido da sua superação. A metamorfose do impasse em liberdade verifica-se, também, no deslocamento da alegoria do "inseto-prisioneiro" do "país bloqueado” na direção do símbolo. A “orquídea-áporo”, em que pese a ruptura com o estado de impasse e a abertura às possibilidades mais diversas, conserva intacto o seu caráter de "mistério”, muito próximo do oxímoro de “claro enigma” “(oh razão, mistério)”. Com ser “verde” e “antieuclidiana”, vê reforçados os seus atributos inusitados de imprevisibilidade e irredutibilidade a prisões formais e ao aspecto ornamental (o "deslizar de lanchas entre camélias”, tão propriamente parnasiano e burguês). Com ser "sozinha” e, segundo as alusões contextuais, tão contemporânea, recusa a distância temporal e o ethos heróico, próprios dos relatos épicos, o que, de resto, estará de acordo com a perspectiva individual e cotidiana, que não comporta nem o monumental nem o sublime.

Há críticos que se inclinam pelo simbolismo da figura, preterindo os aspectos “referenciais”, tidos como possíveis mas irrelevantes, ou indesejáveis (as prisões no Estado Novo e em outros regimes totalitários) em favor da identidade com o mito; dessa perspectiva, a situação “labiríntica” evocaria o simbolismo mítico do Minotauro ${ }^{104}$, e o "sentimento do mundo" estaria restrito preferencialmente a aspectos da estrutura poética, confirmando-se assim a tese de Adorno quanto à presença mais eficaz da história na subjetividade lírica ${ }^{105}$. Não há que se negar a validade desta abordagem, uma

104 "Em meio à perplexidade, pode-se remontar ao mito, mas desde a fonte mítica, o labirinto é o lugar da ambivalência - o machado de duplo gume, chamado labrys, pode ter dado origem à palavra - e da mistura heterogênea, de que o monstro, metade homem, metade touro, é o símbolo. A arquitetura dos caminhos desencontrados foi atribuída, como se sabe, a Dédalo, personagem lendária cujo engenho articulatório parece encarnar a inteligência prática a que os gregos deram o nome de metis: ao novelo de histórias de sua astúcia se liga também o fio de Ariadne. A memória do mito nos enlaça a dificuldades ainda maiores e só reforça o nó, no centro do enredo." "O labirinto que 'presto se desata' é a mudança latente que ele mesmo alimenta em seu interior: imagem misturada que o trabalho ironicamente inventa para organizar o caos, para dar forma ao heterogêneo, ele guarda em segredo, no entanto, uma nova e misteriosa possibilidade de ser (de que o monstro de Creta ainda é símbolo).” (Davi ARRIGUCCI Jr., op. cit., p 90-91 e p. 94, respectivamente.) 105 “A lírica é a linguagem que dá expressão aos momentos mais densos e importantes da existência. Ela pode muito bem voltar as costas aos eventos históricos: 'Não faças versos sobre acontecimentos'. Mesmo quando equivale a um depoimento negativo de um determinado período histórico que ela recusa, omite ou do qual se exime, reclusa na interioridade isolada do indivíduo, com plena consciência da sua inutilidade no mundo de 
vez que a poética drummondiana, de fato, não é panfletária e encoraja, mesmo, diversas construções de significados, porque a sua característica é a pluralidade significante. Por outro lado, não se deve perder de vista que $A$ rosa do povo tem como proposta a intervenção em diversos níveis do real, e não recusa a dimensão da crônica, isto é, a referência aos fatos imediatos, conjunturais, muito embora não se queira restrita a ela e nem o faça de maneira exclusivamente "temática"106.

“Áporo” denuncia, pela linguagem cifrada e/ou elíptica, o “silêncio” imposto pelo nazifascismo, "etapa de degenerescência do capitalismo", segundo entendiam à época os intelectuais e artistas participantes ${ }^{107}$. Mais que discursar sobre esse silêncio, a poética drummondiana prefere referi-lo através de recursos formais. Mas o entendimento desse aspecto só pode ser alcançado por pressupostos críticos que historicizem o texto, isto é, que não se recusem a considerar o(s) contexto(s), tanto o da escrita como o(s) da(s) leitura(s), como elemento importante para o entendimento das dimensões textuais, que o(s) comportam, muito embora sempre guardando uma autonomia relativa $^{108}$.

Por fim, vale notar que alguns críticos se viram tentados a recolher esse poema à categoria, proposta pelo próprio poeta, dos “exercícios lúdicos” (“Uma, duas argolinhas”), como foi o caso de Francisco Achcar ${ }^{109}$, ou então se viram tentados a classificá-lo como pertencente ao "bloco do fechamento do discurso", supostamente contraposto ao "bloco do engajamento", como foi o caso de Iumna Simon. O próprio poeta, entretanto, ao situá-lo na categoria “choque social” (“Na praça de convites”), em

fora, ainda assim, faz ressoar no mais íntimo de sua linguagem os ecos do mundo. O labirinto de 'Áporo' demonstra isso cabalmente." (Idem, ibidem, p. 104).

106 Cf. os ensaios "Drummond prosador" e "Fazia frio em São Paulo", de Antonio Candido (in: Recortes, p. 11-22).

$107 \mathrm{Na}$ entrevista que Drummond concedeu a Ary de Andrade em fevereiro de 1945 (in Sônia BRAYNER, Carlos Drummond de Andrade, p. 30-36), esta idéia se encontra presente nas falas de entrevistador e entrevistado. Afirma o entrevistador: "Combater uma idéia com outra é uma coisa. Lutar contra uma revolução profunda, que vem abalando o âmago da estrutura capitalista do mundo, não com as armas dos cavalheiros, porém com a traição dos vilões, é próprio do fascismo. (...) O fascismo - isto é, o supercapitalismo encamisado - só será extirpado, como está sendo nesta luta universal, à bala." (p. 31) Afirma o entrevistado: "As contradições desse mundo se refletem na própria guerra em que ele se estorce e em que, sob o sacrifício e a sinceridade de milhões de pessoas, não é difícil enxergar o cálculo e a ambição de alguns. A guerra vem apenas evidenciar a existência de certos aspectos caducos de uma organização ou ativar a decomposição de outros. Não é, em si, um processo regenerador." (p. 32)

108 Antonio CANDIDO, “A literatura e a vida social”, in: Literatura e sociedade, p. 17-39.

${ }^{109}$ In Carlos Drummond de Andrade, p. 66: "Ativando esses três sentidos, o poema relata a estória de um áporo (inseto cavador) que, num áporo (uma situação sem saída, um impasse), se transforma num áporo (uma orquídea). O texto se monta, pois, sobre um jogo de palavras, motivo de sua inclusão entre os 'exercícios lúdicos'." Vale ressaltar que, apesar do engano quanto à "classificação" do poema pelo próprio Drummond (que não o coloca em "Uma, duas argolinhas"), Achcar sublinha que "“Áporo', sob a capa de uma brincadeira, um 'exercício lúdico', é um ponto de cruzamento de três áreas temáticas centrais de $A$ Rosa do Povo, assim como de toda a poesia de Drummond: a existência, a sociedade e a própria poesia.” (p. 67). 
sua Antologia, parecia chamar a atenção para o amálgama de intervenção política e inventividade estética, tanto mais significativo (ou “antológico”) quanto mais incorpora a consciência de que a linguagem poética, com ser intrinsecamente social, deve resultar de escolha, mostrando-se, portanto, avessa ao lugar-comum, mas voltando-se necessariamente para o aspecto relacional (transitivo), que implica a liberdade como ato de volição, isto é, como ato subjetivo de vontade e de desejo, entrelaçado com as dimensões objetivas da necessidade e da possibilidade e, sobretudo, mediado pela consciência formal.

É o próprio poeta que, numa crônica de Passeios na Ilha $^{110}$ (livro publicado em 1952 e que repensa muito da experiência poética de A rosa do povo), observa, a respeito do seu projeto de compor uma antologia de “poesia social” brasileira:

Doce é projetar, rude é cumprir. Por isso, não se publicou ainda a antologia brasileira de poesia social, que o autor destas linhas levou dois anos a compor, caceteando feio e forte amigos daqui e de São Paulo. Lidas algumas centenas de volumes, sobraram uns tantos poemas, que pareceram bons ou passáveis, e foram organizados segundo o plano da obra. Restava juntar-lhes notas explicativas. Não juntei. Os originais formam um bolo bastante incômodo na gaveta, e cada vez que olho para esse bolo, me pergunto: Valerá a pena?

(...) Ao coligir o material da obra, notei a relativa escassez de poemas inspirados nas técnicas de trabalho e na personalidade dos trabalhadores. Boa parte de nossa poesia social fica em declaração de princípios, isto é, não chega a produzir-se. O poeta canta-se a si mesmo, como arauto de novos tempos, intérprete de verdades eternas, justiçador de tiranos. A missão da poesia é um dos temas constantes na preocupação de nossos vates sociais, parecendo, contudo, que o enunciado dessa missão basta em muitos casos ao poeta, dispensando-o de cumpri-la. Já não me refiro à atitude revolucionária que o gênero suscita, senão implica. Mesmo sem o propósito de modificar a vida, o poeta se afirmará social buscando refleti-la nos aspectos que definam as relações de trabalho, as condições de existência individual ou coletiva, os traços característicos de cada profissão ou ofício, sob os artifícios habituais de estilização e romantização. Dir-se-á que nem tudo isto é poetizável, objeção aliás que seria lícito ao adepto das formas sociais da poesia refutar com a alegação de que apoéticos não são nunca os assuntos, porém os poetas quando não sabem tratá-los. De qualquer modo, observa-se em nossa poesia de caráter "público", tão afeiçoada ao prosaico, certa falta de familiaridade com os temas do trabalho, que por sua natureza são ricos e sugestivos.

\footnotetext{
110 Trata-se de "Trabalhador e poesia" (in Poesia e prosa, p. 832-836). Esta crônica, muito lúcida não apenas no que diz mas na maneira pela qual se expressa, aproxima-se muito do texto "Instinto de nacionalidade", escrito por Machado de Assis em 1873, porque ambos percebem que a expressão literária, seja sob a preocupação de figurar o espaço nacional, seja sob a preocupação de figurar a questão do trabalho; deve superar a "cor local", isto é, a mera referência, que não se torna experiência lingüística profunda, ou "sentimento íntimo", dissolvendo-se antes na superfície (ou superficialidade) do plano textual. (Antonio CANDIDO, Formação da literatura brasileira, p. 327.
} 
Quando se dispõem a cantar a vida ou o tipo de ocupação dos trabalhadores, nossos poetas demonstram preferir a generalidade, ou, quando muito, aqueles tipos que encerrem um símbolo evidente. De ordinário, cantam simplesmente o trabalho, ou o trabalhador em geral, uma espécie abstrata de trabalhador. (...)

De resto, é preciso incluir no ativo de nossos poetas modernos a preferência que passaram a dar aos temas brasileiros em geral, e entre esses, embora sem preocupação especial, aos da vida de nosso trabalhador urbano ou rural, já sem ênfase retórica. Pode-se dizer que foram os primeiros a ver o homem brasileiro na humildade de sua vida de todos os dias, e a procurar extrair desse cotidiano um sentido poético. Os meninos carvoeiros de Bandeira, que "vão tocando os animais com um relho enorme" e voltam "mordendo num pão encarvoado", ou os seus camelôs, que "ensinam no tumulto das ruas os mitos heróicos da meninice”, são primores de observação realista transfigurados pela mais pura e gratuita poesia. Até o advento do modernismo, seriam inadmissíveis na poesia brasileira. E com eles vêm o patético seringueiro de Mário de Andrade, o Sebastião Pescador, de Ribeiro Couto, que, morrendo, "foi viver no macio"; o lavrador de Cassiano Ricardo (a mão "enorme, a escorrer seiva, sol e orvalho"; as lavadeiras, deste último e as de Jorge de Lima; os estivadores de Cid Silveira; e toda a galeria de músicos de café e casas de chá, vendedores de passarinho, barbeiros, cabeleireiros, sapateiros e caixeiros de sapataria, que desfilam numa elegia de Vinicius de Morais, onde a ironia não exclui ternura e solidariedade. Assim, se desenvolve, por iniciativa dos modernos, $e$ independente de intenção política, a integração do trabalhador brasileiro - do trabalhador de verdade, e não de um símbolo - na poesia nacional. 


\section{3.b. “Anúncio da rosa”}

\section{ANÚNCIO DA ROSA}

1. Imenso trabalho nos custa a flor.

2. $\quad$ Por menos de oito contos vendê-la? Nunca.

3. Primavera não há mais doce, rosa tão meiga

4. onde abrirá? Não, cavalheiros, sede permeáveis.

5. Uma só pétala resume auroras e pontilhismos,

6. sugere estâncias, diz que te amam, beijai a rosa,

7. ela é sete flores, qual mais fragrante, todas exóticas,

8. todas históricas, todas catárticas, todas patéticas.

9.

10.

Vede o caule, traço indeciso.

11. Autor da rosa, não me revelo, sou eu, quem sou?

12. Deus me ajudara, mas ele é neutro, e mesmo duvido

13. que em outro mundo alguém se curve, filtre a paisagem,

14. pense uma rosa na pura ausência, no amplo vazio.

15. Por preço tão vil mas peça, como direi, aurilavrada,

16. não, é cruel existir em tempo assim filaucioso.

17. Injusto padecer exílio, pequenas cólicas cotidianas,

18. oferecer-vos alta mercancia estelar e sofrer vossa irrisão.

19. Rosa na roda,

20. rosa na máquina,

$21 . \quad$ apenas rósea.

22. Selarei, venda murcha, meu comércio incompreendido,

23. pois jamais virão pedir-me, eu sei, o que de melhor se compôs na noite,

24. e não há oito contos. Já não vejo amadores de rosa.

25. Ó fim do parnasiano, começo da era difícil, a burguesia apodrece.

26.

27.
Aproveitem. A última

rosa desfolha-se. 
Diferentemente de “Áporo”, “Anúncio da rosa” é um poema muito pouco lido pela crítica. Iumna Simon, embora o tome como título do primeiro capítulo da primeira parte de seu estudo (““Anúncio da rosa’: o canto se oferta ao povo”), não chega a interpretá-lo diretamente, uma vez que, no referido capítulo, detém-se sobre a análise de outro poema, "O elefante”.

Essa primeira parte, intitulada "Poética do risco: o risco da poesia”, investiga a “dominante” de A rosa do povo, que seria a “abertura do discurso à comunicação” pelo predomínio da "função referencial”, e que atingiria o seu grau máximo na chamada "lírica de guerra”, ou “bloco do engajamento”, sobre cuja análise detém-se o segundo capítulo. O primeiro capítulo consiste em interpretar “O elefante”,

... cujo processo de construção se realiza numa adequação perfeita entre os planos da expressão e do conteúdo: se o plano do conteúdo desenvolve-se como metalinguagem do processo de construção da lírica social, com todas as tensões que o percorrem, o plano da expressão configura-se como ícone dessas tensões, na medida em que oscila entre uma abertura ao referencial (função comunicativa) e um fechamento em direção da própria mensagem (função poética). ${ }^{111}$

Assim, a análise de “O elefante” permitiria demonstrar que a "abertura à comunicação” (“engajamento”, ou "transitividade”) se faz sob a consciência de sua natureza contraditória em relação ao “propriamente poético”, na medida em que “participar” da realidade social implicaria o enfraquecimento do potencial “poético”, e uma maior aproximação no sentido do "prosaico".

Essa conclusão quanto a “O elefante”, como se vê, estende-se a toda a poesia engajada, que, no entender de Iumna, "se oferta ao povo" mas guarda consciência do “risco" de perder sua potência poética, ao imiscuir-se no âmbito referencial da realidade histórica. Pode-se deduzir, então, ser este o significado que a estudiosa atribui a “Anúncio da rosa”.

O estudo de John Gledson, contudo, discorda das premissas dessa interpretação:

${ }^{111}$ Iumna SIMON, op. cit., p. 75. 
O livro mais recente de que vamos tratar aqui é o de Iumna Maria Simon, Drummond - Uma poética do risco (...). O título do livro indica a sua qualidade fundamental - a sua apreciação do que nós chamamos a "precariedade" desta poesia. Outra vez, há aqui análises excelentes de poemas individuais notadamente de "O elefante". Mas, outra vez, infelizmente, creio que as bases teóricas do livro não condizem com a poesia, e com o verdadeiro pensamento drummondiano. Sobretudo, divide a poesia em duas tendências principais grosseiramente, "pura” e "engajada". Volta, assim, a utilizar o critério "social" numa nova forma, opondo-o a um critério aceito pela crítica recente mas que é, se não me engano, muito perigoso aqui - o de uma possível pureza poética à maneira de Mallarmé ou de Valéry. Creio ter mostrado aqui (no Capítulo VI) que Drummond se interessava - justamente em A Rosa do Povo por estas idéias, mas porque as rejeitava. (...) A importância concedida às palavras em, por exemplo, "Procura da poesia" tem outro sentido. Na convivência - impura - com elas, Drummond sente que há um contato com uma realidade objetiva, qualquer que seja a sua forma ou sentido. Há um caminho, noutras palavras, do mundo exterior aos poemas, e dizer que a poesia pode purificar-se nem chega a ser hipótese respeitável para o poeta (...). Também na poética, Drummond nos força a abandonar ou a pôr em dúvida posições $e$ teorias aceitas.

A nossa teoria, que vamos expor brevemente agora para a compreensão mais fácil deste livro, tenta evitar as dificuldades apontadas acima, enfocando a relação entre o poeta e as múltiplas estruturas objetivas - sociais, lingüísticas, familiais, literárias, existenciais, econômicas, históricas etc. - pelas quais se sabe limitado, mas que é - naturalmente - incapaz de descrever, e menos ainda de dominar. Os poemas, nas suas estruturas variadas, representam etapas diversas na tentativa de capturá-las e compreendê-las - tentativa que chega ao seu ponto mais ambicioso em A Rosa do Povo. ${ }^{112}$

Para o crítico, então, embora a poética de Drummond não se restrinja ao real objetivo, vê-se profundamente marcada por ele, e em nenhum momento se recusa ao contato, inclusive nos poemas de aparência mais enigmática, como no caso de “Áporo”, “Ontem”, “Fragilidade” e “O poeta escolhe o seu túmulo” (que para Iumna, diferentemente, correspondem ao "bloco do fechamento”).

Todos estes quatro poemas giram em torno do ponto onde a evanescência (ou, no caso de "Áporo", o extremo oposto, a paralisia) se plasma numa forma mais ou menos satisfatória; ponto que a habilidade do poeta torna também evanescente (...). Estes poemas são todos enigmas, em algum sentido - mas o enigma a que visam é o do poema, e da poesia em geral. Notemos que, na medida em que são enigmas, estes poemas são a demonstração mais clara possível da teoria imitativa implícita no livro. Os poemas imitam a experiência do mundo real até nos seus momentos mais evanescentes, e fazem-no sem desespero. $^{113}$

112 John GLEDSON, Poesia e poética de Carlos Drummond de Andrade, p. 16-17.

113 Idem, Ibidem, p. 192. 
A presente pesquisa concorda com John Gledson quanto à representação de aspectos do real objetivo, tanto nos poemas mais quanto nos poemas menos “enigmáticos”, mas discorda quanto à “teoria imitativa implícita no livro”. A tese do crítico consiste em que as experiências contemporâneas da realidade objetiva comportam percepções fragmentárias, que os poemas drummondianos representariam, especialmente no que figuram de enigmático e de alienado, muito embora guardem aguda consciência desse alheamento, expressando-a mimeticamente e estabelecendo, mesmo, um grau máximo de compreensão, embora nunca como totalidade. (Gledson identifica essa “mimese” como “precariedade”).

No livro de 1945, o poeta chega a vislumbrar o "sistema" total que rege o universo, sistema que nomeia de várias maneiras, as quais sugerem, entretanto, que ele é indefinível - "negócio”, "Fulana”, “A Grande Máquina”. Qualquer forma coerente que descobre entre o caos da experiência é, assim, até certo ponto misteriosa - "forma obscura", "forma indecisa", "a última rosa". Mas esta indefinibilidade do sistema total do mundo não leva ao desespero: pelo contrário, o poeta acredita que ele, e outros artistas - Chaplin, por exemplo - podem capturar algo desta forma inapreensível na arte. A poesia pode entrar nas coisas e nas palavras, juntando-as da mesma maneira que o "sistema” total, sinistro e de operação tão misteriosa. Por meio da língua, e de uma utilização consciente, ativa e até rebelde das suas convenções e estruturas, podemos compartir a mesma experiência real, apesar da influência dos sistemas que nos regem. Em termos filosóficos, mostra que este Drummond cético é uma espécie de kantiano - "o recurso de Kant e da poesia" é verso irônico mas sugestivo deste livro central. Privado de explicações religiosas da existência, não obstante chega a uma espécie de fé. É uma fé, sobretudo, na possibilidade de uma humanidade comum, apesar da fragmentação que o mundo moderno nos impõe, e que se evidencia na arte e na poesia em particular. ${ }^{114}$

Cabe notar que, em nenhum momento, o estudioso atenta para que a poética drummondiana, embora figure os aspectos objetivos e subjetivos do “alheamento”, encaminha-se contudo no sentido de transfigurá-los, integrando-os conceitualmente, o que já não é mais apenas “mimese” nem, tampouco, “precariedade”. E, embora o crítico afirme, com precisão, a sua busca por

entender - na medida do possível - esta poesia nos seus próprios termos, e não à luz de qualquer ideologia ou contexto exterior a este mundo complexo mas coerente

\footnotetext{
${ }^{114}$ Idem, Ibidem, p. 17.
} 
e que é

preciso entender o que ele diz, sem categorizá-lo a priori como amostra de uma espécie ou prova de uma teoria filosófica ou literária ${ }^{115}$,

não considera, entretanto, em nenhum momento da sua análise, a dimensão engajada da poética drummondiana de 1945, e, portanto, deixa de fora quaisquer preocupações políticas, reduzindo-as à perspectiva filosófico-existencial - que a coletânea talvez comporte, mas não em separado do engajamento sócio-político. (Não haveria, por exemplo, “metafísica” em A rosa do povo, uma vez que o "poeta do finito e da matéria” não admite nenhuma transcendência, porque antes logra integrar o simbólico e o concreto como contrafaces, embora complexas, dum real mais amplo.)

De todo modo, ainda que abstraia essa dimensão imprescindível para o entendimento da coletânea de 1945, e que por isso mesmo não analise “Anúncio da rosa” em profundidade (o que talvez seja a marca silenciosa do contexto da sua leitura crítica: a bipolaridade da "Guerra Fria” e o autoritarismo da ditadura militar no Brasil), John Gledson aponta questões importantes na quarta estrofe do poema:

Aqui temos a precariedade, evidente no fato de que o poeta está incerto da sua própria identidade (certo, contudo, de que é o autor); mas também temos a afirmação da relação entre o poeta e a realidade. O último verso lembra, creio que intencionalmente, este célebre trecho do ensaio de Mallarmé, "Crise de vers":

"Je dis, une fleur! et, hors de l'oubli où ma voix relèue aucun contour en tant que quelque chose d'autre que les calices sus, musicalement se lève, idée même et suave, l'absente de tous bouquets".

Segundo Mallarmé, falar, e mais ainda escrever, é uma abstração que abole (palavra predileta do poeta) a flor real, individual. Ou, conforme diz Mallarmé no mesmo ensaio, se a pedra estivesse realmente presente, não poderíamos fechar o livro! Evidentemente, nenhum dos dois inclui as coisas no poema neste sentido. Drummond distingue-se de Mallarmé pela sua crença de que as palavras e a poesia (que habita o "reino das palavras") refletem a estrutura da realidade. "Apenas um rastro, não importa": as coisas estão presentes pelos seus sinais, pelas suas marcas, não em si mesmas - em algum sentido estão presentes e ativas no poema e na sua formação.

A poética de Drummond em A Rosa do Povo, como noutros momentos, pode sugerir uma poética simbolista e principalmente mallarmeana. Em particular, a sua idéia de que a poesia é um arabesco que abraça as coisas sem reduzi-las lembra o ideal mallarmeano de que a poesia deve sugerir e não

\footnotetext{
115 Idem, Ibidem, p. 11.
} 
nomear as coisas; a sua justificação da obscuridade pode ser outro ponto de contato. Os paralelos são reais $e$ interessantes, mas a diferença apontada é muito mais essencial. ${ }^{116}$

De fato, ainda que Drummond retome a consciência de que as "palavras" (metonímia de “signo” e de "linguagem”) não são imediatamente aquilo que se pretende representar, isto não permite que se atribua ao poeta de 1945 (ou a uma das "faces" de sua obra) a categoria de mallarmeano, visto que ele antes reafirma o vínculo entre o real concreto e o real simbólico, ainda que o faça com respeito à complexidade desse trânsito, e nunca como "mimese” (no sentido pouco mediato do termo). Por isso mesmo, a problemática da “autoria”, do “consumo” e do próprio “ser” da “rosa”, em que pese a sugestão de "precariedade" ou alheamento, não consiste em "imitação do drama existencial do indivíduo contemporâneo num mundo obscuro”, como significado último (quando muito, este significado é denotativo, e portanto provisório).

O presente capítulo, ao investigar os possíveis significados que a "flor” (sob a forma de "rosa”, “orquídea” etc.) assume na coletânea, tem como hipótese que o engajamento poético vai no sentido oposto ao da separação entre estética e política. A “flor”, ao percorrer o alegórico e o simbólico, participa da construção de uma poética extremamente complexa, que se apropria dos signos em sua dimensão cotidiana, “vulgar”, figurando-os em movimentos opostos, mas complementares, de desfiguração e transfiguração. Dessa maneira, as práticas simbólicas orgânicas, exiladas do cotidiano pela reificação das sociedades capitalistas, reintroduzem-se na experiência humana (a um tempo individual e coletiva) sob a escala da vida diária, ressignificando-a, em vez de apenas confrontá-la. Por esse motivo, a “flor”, como metonímia de "poética”, em vez de apenas referir-se ao real de maneira imediata (com permitir que sejam feitos "versos sobre”), possibilita antes a mediação sobre o real, de maneira a renomeá-lo.

Diferentemente de “Áporo”, “Anúncio da rosa” é um poema em que o envolvimento político não assume o paradoxo de explicitar-se pela linguagem cifrada,

116 Idem, Ibidem, p. 197. 
muito embora comporte outro paradoxo: o de tornar-se implícito, quando aparentemente se explicita. Talvez por isso, a fortuna crítica do poeta tenha-se dispensado de analisálo, tomando os seus significados como óbvios e, portanto, “menores”117, quando na verdade o seu aspecto de engajamento aparente está longe de esgotar todo o processo significativo, cuja compreensão mais detida é fundamental para que se reflita sobre o conceito de "participação” em A rosa do povo.

O “anúncio da rosa” não é só o enunciado do combate aos valores capitalistas; ele é sobretudo uma experiência reflexiva quanto à natureza inevitavelmente "engajada" do trabalho artístico. O “engajamento”, em A rosa do povo, não é a profissão de fé do poeta em termos anticapitalistas; é antes a percepção do empobrecimento simbólico num universo social reificado, com vistas a transcendê-lo. Abordar a coletânea com pressupostos dicotômicos em relação às tendências “social” / “formalista” é, na verdade, reproduzir uma percepção que a própria poética supera, com ser integrativa.

Em “Anúncio da rosa”, todos os elementos do discurso poético encontram-se figurados: a autoria, a própria obra, o público e os contextos de produção e recepção. Não é no plano imediato dessas figuras, entretanto, que se devem buscar os significados do poema, sob pena de reduzir a figuração às figuras, das quais o poema guarda evidente distanciamento.

A “rosa” é a figuração alegórica do fazer poético, mas termina por desfigurar-se (“desfolhar-se”) como forma de transfigurar o seu estatuto de objeto simbólico desprovido de valor (no momento da transfiguração, deixa a alegoria em direção ao símbolo). Nesse processo figurativo, o fazer poético enuncia a sua precariedade ao

\footnotetext{
117 MERQUIOR (op. cit., p.72-122 ) não analisa "Anúncio da rosa", mas considera "menor" toda a "lírica social" em que o engajamento é supostamente explícito e comporta o "sublime" e o "utopismo". Esse juízo de valor dirige-se não apenas aos significados "realistas" (que, segundo o estudioso, a crítica "marxizante" e "sociológica" da poesia drummondiana à propriedade privada dos meios de produção representaria, considerando-a a priori como pouco inteligente), mas dirige-se também aos aspectos estilísticos: "José nos ensinou que a elocução 'pura', a ausência de humor e de perspectiva grotesca podem manter-se em Drummond fora do tom sublime. O gênero epidíctico em $A$ Rosa, representado sobretudo por poemas de guerra (...) e pelas duas grandes odes a Mário de Andrade e a Carlitos, assinala entretanto a ascensão do pathos sublime, se bem que este não tome necessariamente a forma da idealização romântica. Do ponto de vista do estilo, há, pois, em Drummond ao menos duas estéticas do sublime: uma prolonga a elocução neo-romântica nascida com Sentimento do Mundo; a outra aborda o sublime com a contenção, o antipatetismo característico da arte moderna. Além disso, o estilo 'puro' em A Rosa do Povo contém três esferas temáticas isentas do sublime: a poesia sobre a poesia; o lirismo filosófico (...) e enfim uma certa poesia do cotidiano.” (p. 108-109, grifos do autor). "Com José e A Rosa do Povo, isto é, com sua poesia composta de 1941 a 1945, Drummond traz ao modernismo três conquistas decisivas para o desenvolvimento da literatura brasileira: um realismo social excepcionalmente penetrante, muito acima do lirismo declamatório da poesia engajada; uma poesia metapoética, nutrida de uma espécie de reflexão introspectiva da escrita; um lirismo, enfim, de interrogação existencial, preludiando o desenvolvimento do poema filosófico que caracterizará os livros posteriores como Claro Enigma. (...) Vindo após a 'escorregadela' neo-romântica de Sentimento do Mundo, o lirismo de A Rosa do Povo se divide entre a ótica grotesca em 'estilo mesclado' e um estilo 'puro' não menos moderno." (p. 121, grifos do autor).
} 
revelar-se como trabalho social, como um fazer concreto que busca (mas não consegue) estabelecer mediações entre uma série de necessidades conflitantes em determinado contexto. Ao mediar as necessidades do “autor” e do "público”, a "rosa” termina por “representar” atributos diversos, que dizem respeito não só à sua complexa condição de elemento social concreto e de símbolo, mas a aspectos da própria época a que pertence.

Como fruto de trabalho social, a "rosa” expressa um valor econômico e, ao fazêlo, explicita não apenas a sua temporalidade de símbolo, mas também as relações concretas de que advém. Embora a linguagem que o autor emprega para "anunciá-la” mimetize (parodicamente) muito da expectativa dos “cavalheiros” quanto à "alta mercancia estelar”, o tempo de sua produção vem sublinhado, e pressupõe "padecer exílio, pequenas cólicas cotidianas”, de tal maneira que a perspectiva sincrônica da fruição estética (que é o seu "valor de uso”, e remete ao “alto” ou sublime) não oculta (antes explicita) a perspectiva diacrônica do esforço criativo (que é o seu "valor”em termos produtivos, e remete ao "baixo", ou cotidiano).

A “irrisão" ("rebaixamento") que o "autor da rosa” sofre e que o valor econômico do produto de seu trabalho termina por expressar (com a "desvalorização" da “rosa”) não advém apenas do desconhecimento quanto às suas qualidades estéticas (“altas”), tão bem “anunciadas”, mas também de desconsiderar-se o tempo da produção artística (de que o vocábulo "irrisão” é muito expressivo, na medida em que significa “escárnio", mais no sentido de “descarnar” que no sentido de “ridicularizar”). O preciosismo lexical, que se expressa pelo emprego da segunda pessoa do plural em referência a “cavalheiros”, bem como pelo uso de alguns vocábulos e construções sintáticas “elevados”, denuncia as necessidades simbólicas do público, já que a “publicidade” (um dos sentidos de “anúncio”) procura ressaltar os atributos "sublimes” da “rosa” como forma de convencê-lo ao consumo, criando identidade entre "público” e "produto". 118

\footnotetext{
118 Sobre a figuração da "publicidade", o poema "Nosso tempo" é bastante expressivo. Vejam-se os seguintes versos:

88. No beco,

89. apenas um muro,

90. sobre ele a policia.

91. No céu da propaganda

92. aves anunciam

93. a glória.

94. No quarto,

95. irrisão e três colarinhos sujos.

Neste poema longo, a experiência formal da fragmentação, ela própria vertiginosamente descontínua e complexa, provoca uma separação, de natureza a um tempo sinestésica e cognitiva, entre os significados das palavras empregadas e os seus significantes, de que os versos seguintes são emblemáticos:
} 
Cabe notar, entretanto, que o descompasso entre o "valor econômico", expresso em termos monetários "baixos” (“por preço tão vil”), e o "valor de uso”, expresso em termos do “alto” literário (“alta mercancia estelar”), enunciado como a possibilidade de “rebaixamento" do artista e de seu trabalho mediante o “escárnio", termina inversamente por 'rebaixar” o próprio sujeito da “desvalorização”. Ao reduzir a multiplicidade de valores e de sentidos da "rosa” à “vileza” da mercadoria (esvaziandoa, portanto, de simbolismo), o “respeitável público” não se encontra à “altura” do símbolo, que tanto esforço fez por identificar-se com quem lhe deve conferir realidade: o público ${ }^{119}$. É a "baixeza” do público (“escarninho”, incapaz de reconhecer o justo valor da obra, não apenas em termos estéticos e simbólicos mas também em termos de esforço produtivo) o que cria um descompasso entre o real simbólico e o real concreto.

Essa "baixeza” é o sentido da ironia que a palavra “anúncio” representa. Inicialmente, trata-se do esforço publicitário para criar identidade entre "rosa” e “cavalheiros”, mas, na medida em que o "preço” estabelecido pelos “cavalheiros” atribui um significado "vil” para a "alta mercancia estelar”, o "autor” inverte os termos da relação, recusando o valor estabelecido por não estar à “altura” do seu trabalho. Nesse momento, o "anúncio" deixa de ser "publicidade" e se torna a recusa da

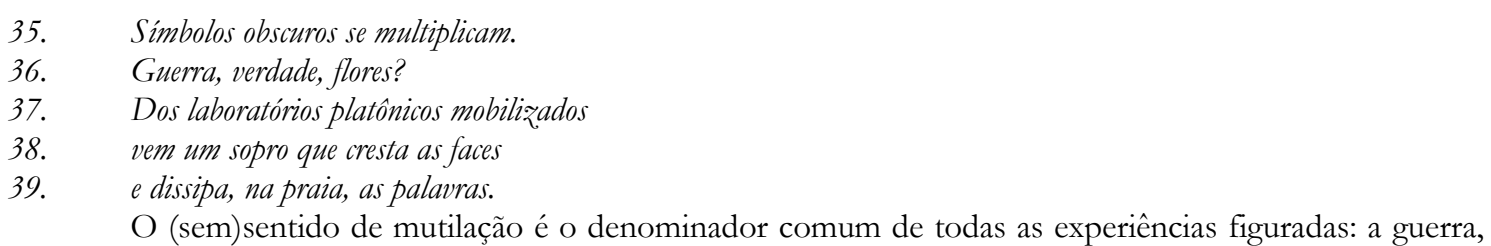
o cotidiano, as linguagens simbólicas todas, inclusive a própria poesia, que se figura nivelada em dois planos (o formal e o temático) em relação à linguagem publicitária.

Esta experiência poética vai ao encontro da análise de Henri Lefebvre, que observa a operação simbólica tipicamente capitalista que a mercantilização das relações sociais opera ao separar significante e significado, o que se percebe de maneira mais específica na linguagem publicitária (op. cit., p. 62-79).

119 "Para compreender em que sentido é tomada a palavra formação, e porque se qualificam de decisivos os momentos estudados, convém principiar distinguindo manifestaçôes literárias, de literatura propriamente dita, considerada aqui um sistema de obras ligadas por denominadores comuns, que permitem reconhecer as notas dominantes duma fase. Estes denominadores são, além das características internas, (língua, temas, imagens), certos elementos de natureza social e psíquica, embora literariamente organizados, que se manifestam historicamente e fazem da literatura aspecto orgânico da civilização. Entre eles se distinguem: a existência de um conjunto de produtores literários, mais ou menos conscientes de seu papel; um conjunto de receptores, formando os diferentes tipos de público, sem os quais a obra não vive; um mecanismo transmissor, (de modo geral, uma linguagem, traduzida em estilos), que liga uns a outros. O conjunto dos três elementos dá lugar a um tipo de comunicação inter-humana, a literatura, que aparece sob este ângulo como sistema simbólico, por meio do qual as veleidades mais profundas do indivíduo se transformam em elementos de contacto entre os homens, e de interpretação das diferentes esferas da realidade." (Antonio CANDIDO, Formação da literatura brasileira, p. 23, grifo nosso.)

"Como se vê, não convém separar a repercussão da obra da sua feitura, pois, sociologicamente ao menos, ela só está acabada no momento em que repercute e atua, porque, sociologicamente, a arte é um sistema simbólico de comunicação inter-humana, e como tal interessa ao sociólogo. Ora, todo processo de comunicação pressupõe um comunicante, no caso o artista; um comunicado, ou seja, a obra; um comunicando, que é o público a quem se dirige; graças a isso define-se o quarto elemento do processo, isto é, o seu efeito." (Antonio CANDIDO, Literatura e sociedade, p. 21, grifo nosso.) 
mercantilização, entendida como "rebaixamento" do simbólico a termos esteticamente ornamentais e socialmente monetários.

O segundo momento do "anúncio da rosa”, significativamente, abandona o esforço lingüístico por criar identidade entre “obra” e “público”, e por isso abandona o preciosismo lexical e sintático. No vigésimo sétimo verso, a última expressividade daquele tipo é, ironicamente, o "anúncio” da superação de sua realidade estética (“parnasiana”) e social (“burguesa”). “Ó fim do parnasiano” é uma forma ironicamente parnasiana de expressar a caducidade daquele estilo patético e eloqüente (paralelo, inclusive, ao $10^{\circ}$ verso de “Áporo”), enquanto “a burguesia apodrece” é uma forma bastante grotesca, e portanto inversa, de referir a essa caducidade. Neste vigésimo sétimo verso, a ironia se assume enquanto tal, e, já no verso seguinte, o público deixa de receber o tratamento de “vós”, substituído por “vocês”. Nessa forma de tratamento não mais assimétrica, a obra ressurge com potência literalmente reflexiva (“A última rosa desfolha-se.”), capaz de estabelecer identidades entre os elementos textuais e contextuais, não mais como mimese, mas como ressignificação.

Não apenas as figuras de "autor” e "público” importam na “figuração” da “rosa”, mas também a figura do “contexto”. É no "espaço público” que o “autor da rosa” apresenta a sua criação, cujo “anúncio” tende a criar identidades de múltiplas naturezas, por sob a sugerida falta de "reconhecimento”. A mais evidente dessas identidades já se destaca na mimese do estilo "parnasiano" (forma de representar os anseios dos “cavalheiros”). Outra identidade se constrói entre o "autor” e o "fruto da sua autoria”, mediante a figura do "trabalho”, que embora não venha explícita na forma “aurilavrada” (que é “filtro da paisagem”, e não o seu reflexo imediato), nela, entretanto, se imbrica, porque resulta de “exílio, pequenas cólicas cotidianas” e, portanto, deve-se expressar como “valor”. Por fim, uma terceira identidade se estabelece porque a linguagem do "anúncio", por sob aspectos de preciosismo afetado, guarda a familiaridade e a oralidade do pregão, o que permite inferir que o "contexto" da ação seja a "rua”, ou a "praça pública”, com que a "rosa” termina por se identificar, e em que "desfolha-se”.

De fato, a "figuração" do "anúncio” é, por si só, bastante "prosaica”, e muito pouco “dramática”. O seu conteúdo “narrativo”, em si, não traz informações novas, nem desfechos imprevistos, e portanto pouco “significa”. O seu significado resulta, antes, do processo de significação, que é a maneira "improvisada” pela qual ele se torna “dramático”. Assim, as “personagens” (ou figuras) são como máscaras que permitem 
aos “atores” (ou sujeitos deste tipo de “discurso”: não apenas o “artista”, mas também as "pessoas" que participam e, com isso, integram a encenação) dialogar diretamente com o contexto imediato que o "espaço público" representa, de modo a incorporar as suas expectativas e realidades a um repertório previamente conhecido, de "domínio público", no sentido de ressignificá-las. E esse "improviso" deve necessariamente romper com o “distanciamento" (entre encenação e público) e com a "proximidade” (entre a tensão dramática e o público) que o espetáculo institucional hierarquizado pressupõe e que as diversas formas do “cômico" desfazem ${ }^{120}$.

Trata-se, em outras palavras, de uma concepção popular de arte, da arte feita em praça pública, que faz questão de explicitar a si própria como trabalho, como representação, já que o seu fim último não é provocar a catarse nem atingir o sublime, mas restabelecer relações orgânicas entre o simbólico e o concreto, sem rupturas com a dimensão cotidiana. O cotidiano, assim, por meio da "festa", deixa de ser “insignificante”, na medida em que se refaz a transitividade entre os sujeitos e as suas necessidades concretas, através de recursos simbólicos.

A figura do contexto em “Anúncio da rosa” pode representar, como alegoria, o esgarçar das relações capitalistas de trabalho, mas o processo figurativo metalingüístico (em que a poesia representa o próprio fazer poético), com ser simbólico por sob a aparência alegórica, representa a natureza ressignificante duma concepção de arte libertária, o que inclui o contexto imediato mas certamente o transcende, agregando a ele outras possibilidades de significação. A figuração da experiência poética a repensa como um trabalho que remete à natureza do simbólico, mas que não deve romper vínculos com a dimensão do concreto, o que empobreceria sua própria natureza relacional (ou transitiva).

Esse é o sentido especificamente político da arte drummondiana em A rosa do povo, em que a "sociedade” integra a "sete flores” desde a microperspectiva de "uma só pétala”, embora sem se restringir às “cólicas cotidianas”, e tampouco sem se restringir ao seu oposto (o “sublime simbólico” da “alta mercancia estelar”, “aurilavrada”). Esses elementos, figurados de maneira alegórica como “impasse”, transfiguram-se no sentido integrativo, cujo campo semântico não é o da ruptura simples, já que recorre à imagem

120 O conceito de "cômico" remete a BAKHTIN (op. cit.), e não à concepção hierárquica dos três níveis estilísticos (grave, mediocrus, humilis), mas à sua subversão pelo sistema simbólico da "cosmovisão carnavalesca". No poema analisado evidentemente não há a presença integral do sistema simbólico, mas de elementos desse sistema, sobretudo da ironia e da paródia, e da imagem temático-formal da "praça pública", que têm como função restabelecer o relacionamento orgânico na figuração dos elementos discursivos. 
grotesca do apodrecimento, não como fim absoluto, mas como transformação. É com a (re)integração desses pólos de maneira “orgânica” e por meio da ressignificação, mais que do significado, que a "pólis" se faz e refaz, sob o disfarce da "insignificância" cotidiana.

É importante perceber que a figuração da “arte popular” não significa que a poética drummondiana apenas mimetize, na escrita, o seu caráter de oralidade e improviso. Tal dimensão empiricamente verificável nesse poema não é o significado último, nem como temática, nem como aspecto formal, desse ou dos demais poemas do livro, configurando, antes, uma problemática de natureza conceitual (a da redenção recíproca de eu e mundo por meio da representação reflexiva de aspectos "subjetivos" e “objetivos”), cuja constante é a multiplicidade, que visa a rearticular os signos segundo aspectos volitivos / cognitivos.

O desafio central para a crítica drummondiana, em A rosa do povo, consiste em compreender a relação entre o propriamente literário e o que não é imediatamente literário, mas que de fato integra a poética da coletânea como problemática e como prática formal complexa. No caso de “Anúncio da rosa”, um dos poucos e fundamentais poemas da coletânea em que o poeta emprega o símbolo da "rosa”"121 mas que,

\footnotetext{
${ }^{121}$ Empregam a imagem da "rosa" (ou da "flor") os seguintes poemas:

"Consideração do poema", v. 17-19 ("São todos meus irmãos, não são jornais/ nem deslizar de lancha entre camélias:/ é toda a minha vida que joguei.");

"A flor e a náusea";

"Carrego comigo", v. 5-8 ("Serão duas cartas?/ será uma flor?/ será um retrato?/ um lenço talvez?”);

"O medo", v. 6-10 ("E fomos educados para o medo./ Cheiramos flores de medo./ Vestimos panos
} de medo./ De medo, vermelhos rios/ vadeamos.”);

"Nosso tempo", v. 7-9 ("As leis não bastam. Os lírios não nascem/ da lei. (...)");

"Rola mundo", v. 44-46 ("Vi outros enigmas/ à feição de flores/ abertas no vácuo.");

“Áporo”, v. 12-14 (“em verde, sozinha,/ antieuclidiana,/ uma orquídea forma-se.”);

"Ontem", v. 1-3 (“Até hoje perplexo/ ante o que murchou/ e não eram pétalas.");

"Episódio", v. 5-6 ("Vem cheirando o tempo/ entre noite e rosa.");

"Equívoco", v. 7-9 ("Um jardim sempre meu, de funcho e de coral,/ ergueu-se pouco a pouco, e eram flores de velho,/ murchando sem abrir, indecisas no mal.");

“Anúncio da rosa”, v. 11 (“Autor da rosa, não me revelo, sou eu, quem sou?”); e. 7 ("Rosa na roda,/ rosa na máquina,/ apenas rósea.");

"Resíduo", v. 1-4 ("De tudo ficou um pouco./ Do meu medo. Do teu asco./ Dos gritos gagos. Da rosa/ ficou um pouco.’);

"Noite na repartição", v. 26-27 ("Distrais-te na queixa e a mágoa que exalas/ é perfume que te unge, flor que te acarinha."); v. 66-67 (“Fica quieta, me deixa subir/ e fazer no teto um lustre, uma rosa.");

"Retrato de família", v. 13-16 ("O jardim tornou-se fantástico./ As flores são placas cinzentas./ E a areia, sob pés extintos, / é um oceano de névoa.");

"Rua da Madrugada”, v. 18-26 (“desejar amá-lo/ sem qualquer disfarce,/ cobri-lo de beijos, flores, passarinhos,/ corrigir o tempo,/ passar-lhe o calor/ de um lento carinho/ maduro e recluso,/ confissões exaustas/ e uma paz de lã.");

“Carta a Stalingrado", v. 33 (“Que flores, que cristais e músicas o teu nome nos derrama!”);

"Mas viveremos", v. 21-24 ("Muitas vezes julgamos ver a aurora/ e sua rosa de fogo à nossa frente./ Era apenas, na noite, uma fogueira./ Voltava a noite, mais noite, mais completa."); v. 61-72 ("Pouco importa 
sintomaticamente, não tem recebido leituras críticas sistemáticas, o conceito de “social”, como contraponto ao conceito de "literário”, é alvo de inversão irônica, que termina por desfigurar a sua separação reificante no contexto capitalista como forma de transfigurá-la e, assim, “imaginar” a possibilidade de um outro contexto, através do real simbólico.

Nesse processo figurativo complexo, o "não-literário” (segundo a cosmovisão "aristocrática” de que, por comportar a esfera “insignificante” do "humilis”, o “cotidiano” torna-se incompatível com a preocupação problemática, ou "significante”, do "trágico”, ou "sublime”) faz-se “elevar” à categoria “significante” de "literatura”, não como transposição dos sentidos costumeiros para o plano simbólico, mas como elemento mediador necessário nas relações entre o significado e o significante, sem as quais o signo resulta vazio, “informe”. Já a concepção "burguesa” ou “parnasiana” do simbólico, cujo valor estético remete à especialização da forma no sentido do "belo” e do “abstrato” (em que o “trabalho artístico” sofre “escárnio”, “descarna-se”, “pensa uma rosa na pura ausência, no amplo vazio”), encaminha-se em direção ao “insignificante”,

que dedos se desliguem/ e não se escrevam cartas nem se façam/ sinais da praia ao rubro couraçado./ Ele chegará, ele viaja o mundo.// E ganhará enfim todos os portos,/ avião sem bombas entre natal e China,/ petróleo, flores, crianças estudando,/ beijo de moça, trigo e sol nascendo.// Ele caminhará nas avenidas,/ entrará nas casas, abolirá os mortos./ Ele viaja sempre, esse navio,/ essa rosa, esse canto, essa palavra.”);

"Os últimos dias", v. 80-85 ("E todo o mel dos domingos se tire;/ o diamante dos sábados, a rosa/ de terça, a luz de quinta, a mágica/ de horas matinais, que nós mesmos elegemos/ para nossa pessoal despesa, essa parte secreta/ de cada um de nós, no tempo.");

"Mário de Andrade desce aos infernos", v. 1-12 ("Daqui a vinte anos farei teu poema/ e te cantarei com tal suspiro/ que as flores pasmarão, e as abelhas,/ confundidas, esvairão seu mel.// Daqui a vinte anos: poderei/ tanto esperar o preço da poesia?/ É preciso tirar da boca urgente/ o canto rápido, ziguezagueante, rouco,/ feito da impureza do minuto/ e de vozes em febre, que golpeiam/ esta viola desatinada/ no chão, no chão.”); v. 28-54 (“O meu amigo era tão/ de tal modo extraordinário,/ cabia numa só carta,/ esperava-me na esquina,/ e já um poste depois/ ia descendo o Amazonas,/ tinha coletes de música,/ entre cantares de amigo/ pairava na renda fina/ dos Sete Saltos,/ na serrania mineira,/ no mangue, no seringal,/ nos mais diversos brasis, / e para além dos brasis,/ nas regiões inventadas,/ países a que aspiramos/ fantásticos, / mas certos, inelutáveis,/ terra de João invencível,/ a rosa do povo aberta...// A rosa do povo despetala-se,/ ou ainda conserva o pudor da alva?/ É um anúncio, um chamado, uma esperança embora frágil, pranto infantil no berço? / Talvez apenas um ai de seresta, quem sabe./ Mas há um ouvido mais fino que escuta, um peito de artista que incha,/ e uma rosa se abre, um segredo comunica-se, o poeta anunciou,/ o poeta nas trevas anunciou.");

"Canto ao homem do povo Charlie Chaplin", v. 25-28 ("Não é a saudação dos devotos nem dos partidários que te ofereço,/ eles não existem, mas a de homens comuns, numa cidade comum,/ nem faço muita questão da matéria de meu canto ora em torno de ti/ como um ramo de flores absurdas mando por via postal ao inventor dos jardins.”); v. 41-44 (“A noite banha tua roupa./ Mal a disfarças no colete mosqueado,/ no gelado peitilho de baile,/ de um impossível baile sem orquídeas."); v. 56-61 ("E a lua pousa/ em teu rosto. Branco, de morte caiado,/ que sepulcros evoca mas que hastes/ submarinas e álgidas e espelhos/ e lírios que o tirano decepou, e faces/ amortalhadas em farinha. (...)"); v. 141-152 ("Uma cega te ama. Os olhos abremse./ Não, não te ama. Um rico, em álcool,/ é teu amigo e lúcido repele/ tua riqueza. A confusão é nossa, que esquecemos/ o que há de água, de sopro e de inocência/ no fundo de cada um de nós, terrestres. Mas, ó mitos/ que cultuamos, falsos: flores pardas,/ anjos desleais, cofres redondos, arquejos/ poéticos acadêmicos; convenções/ do branco, azul e roxo; maquinismos,/ telegramas em série, e fábricas e fábricas/ e fábricas de lâmpadas, proibições, auroras.”). 
mediante a caricatura (isto é, ao exagero paródico de aspectos do estilo, exclusivamente formais).

Assim é que a poética drummondiana traça um caminho paralelo, embora propriamente "literário", ao do pensamento que rompeu com a "insignificância" tradicionalmente atribuída à esfera “física” (no sentido do “concreto”), e que passou a considerar "filosoficamente significantes" (dignas de reflexão teórica) também as esferas que apenas se percebem no plano cotidiano, em que se tocam a produção e a reprodução da vida material (a “economia”, a “sociologia” etc.). ${ }^{122}$ Não que haja em Drummond um pensamento propriamente “filosófico", cuja natureza é lógicodiscursiva; o seu “pensamento” (ou “sistema simbólico”) é propriamente “poético”, não porque seja predominantemente formal ou, em determinados momentos, predominantemente temático, mas porque na sua complexidade simbólica proporciona intuições a um tempo sensoriais e cognitivas, por meio de recursos figurativos ${ }^{123}$. É um "pensamento" propriamente afetivo e sensorial, mas integra a essas experiências estéticas a intuição de problemáticas concretas. A figuração dessas problemáticas “físicas” não pressupõe ruptura com as problemáticas “metafísicas” (“abstratas”), ao contrário: visa a integrá-las, e é esse o seu sentido propriamente político, e ao mesmo tempo estético.

Os poemas de A rosa do povo que os melhores críticos deixam de investigar ou, quando os interpretam, tomam o nível denotativo como significado último (em que exilam o “engajamento”) são aqueles em que há um distanciamento sutil, e, por isso mesmo, elaborado, dos recursos formais em relação aos significados “prosaicos” (que as “inquietudes” invariavelmente ressignificam). Em “Anúncio da rosa”, por exemplo, a "mescla estilística” não é o simples emprego formal de uma estratégia "baudelairiana" para representar o “cotidiano” sob a perspectiva “problemática”, anteriormente reservada ao "trágico", mas agora a serviço do "realismo", ou do conhecimento “sociológico” ${ }^{24}$. É, antes, a representação (simbólica portanto) do trabalho poético

\footnotetext{
${ }^{122}$ Henri LEFEBVRE, op. cit., p. 20-39.

123 Antonio CANDIDO, O estudo analítico do poema, p. 93-98.

124 MERQUIOR (op. cit.) afirma: "Com $A$ Rosa do Povo se realiza a promessa de Sentimento do Mundo: cantar 'a vida presente'. Diante da realidade burguesa do tempo da guerra, o 'sentimento do mundo' fica historicizado. O lirismo social e engajado se desdobra em literatura 'sociológica'; sem jamais visar ao simples documento, a interpretação lírica se alimenta de uma espécie de análise sociológica bem sua, mas de modo algum menos reveladora que os métodos científicos. (...) $\mathrm{O}$ intelectual marxizante, que é Drummond nessa época, adota assim uma concepção humanista , moralista do processo social, concepção que tende (do mesmo modo que vários ramos do chamado 'marxismo ocidental') a confundir de maneira ingênua o capitalismo com fenômenos 'imorais' que, como a usura, antes pertencem a uma etapa pré-capitalista da economia e da sociedade. Desse modo não nos surpreenderemos ao encontrar a energia máxima do olhar sociológico de
} 
como um ato propriamente social, sem com isso "rebaixar-se”, tornar-se “insignificante”.

Por último, cabe lembrar que Drummond situa “Anúncio da rosa” em “Amaramaro”, ou “o conhecimento amoroso”, o que evidentemente amplia a dimensão do eros no sentido muito mais amplo, e não apenas subjetivo, nem exclusivamente intersubjetivo, de “conhecimento social”. Nada impediria identificá-lo, como o faz Iumna Simon, com o “bloco do engajamento”. A categorização do poeta, entretanto, parece realçar o dinamismo da sua obra: o seu caráter processual.

Drummond, não nessas prosopopéias antinegócio, mas na elaboração poética de instantâneos realistas." (p. 78-79, grifos do autor) Nessas conclusões, que o crítico estende a toda a "literatura social ou engajada" da coletânea (também denominada "literatura sociológica"), cabem pressupostos ideológicos no mínimo discutíveis e sem dúvida "extra-literários", tanto assim que não comportam demonstração analítica, ou, quando muito, seguem-se de trechos de poemas cujos significados denotativos ou "estilísticos" procuram ilustrar a suposta "sociologia drummondiana", negativamente valorada. Entre as páginas 79 e 81, o crítico se detém sobre os significados imediatos de "A flor e a náusea", cuja análise volta nas páginas 104-105 como "demonstração" do seu julgamento de valor: "Em todos os casos, esse tom traz consigo uma imagística convencional, uma linguagem que roça o insípido, de baixa voltagem poética. De uma certa maneira, " $A$ Rosa do Povo" mata o estilo neo-romântico, formado na juventude do lirismo drummondiano, acentuando-lhe os defeitos. Que a inclinação para o sublime, o recrudescimento do pathos idealizante não suporta o confronto com o verso musculoso do estilo mesclado, é o que ressalta em "A flor e a náusea". Já assinalamos a força expressiva da parte mesclada do poema, a que descreve a náusea. Eis entretanto o fim: [Merquior cita os versos 35-49]. É preciso reconhecer que o simbolismo fácil, as imagens inorgânicas, esses grandes nomes abstratos (tédio, nojo, ódio) enfraquecem o poema. A cor estética desses versos é tão imperceptível quanto a de seu símbolo." (grifos do autor). Decorrente dos seus pressupostos político-ideológicos discutíveis, o juízo de valor do crítico é tão precipitado quanto indiscutível, porque mera derivação do gosto pessoal, que no entanto se apresenta como parâmetro absoluto e, com isso, injusto, como injusto seria julgar o valor da sua obra crítica pela opção política que tomou durante o governo Collor, quando, tornado ministro de Estado, pôs-se a serviço da abertura indiscriminada da economia brasileira ao mercado internacional e do privatismo, pautado pela ideologia neoliberal. 


\section{3.c. "Mário de Andrade desce aos infernos"}

\section{MÁRIO DE ANDRADE DESCE AOS INFERNOS}

\section{I}

1. Daqui a vinte anos farei teu poema

2. e te cantarei com tal suspiro

3. que as flores pasmarão, e as abelhas,

4. confundidas, esvairão seu mel.

5. Daqui a vinte anos: poderei

6. tanto esperar o preço da poesia?

7. É preciso tirar da boca urgente

8. o canto rápido, ziguezagueante, rouco,

9. feito da impureza do minuto

10. e de vozes em febre, que golpeiam

11. esta viola desatinada

12. no chão, no chão.

\section{II}

13. No chão me deito à maneira dos desesperados.

14. Estou escuro, estou rigorosamente noturno, estou vazio,

15. esqueço que sou um poeta, que não estou sozinho,

16. preciso aceitar e compor, minhas medidas partiram-se,

17. mas preciso, preciso, preciso.

18. Rastejando, entre cacos, me aproximo.

19. Não quero, mas preciso tocar pele de homem,

20. avaliar o frio, ver a cor, ver o silêncio,

21. conhecer um novo amigo e nele me derramar.

22. Porque é outro amigo. A explosiva descoberta

23. ainda me atordoa. Estou cego e vejo. Arranco os olhos e vejo.

24. Furo as paredes e vejo. Através do mar sangüíneo vejo.

25. Minuciosamente, implacável, sereno, pulverizado,

26. é outro amigo. São outros dentes. Outro sorriso.

27. Outra palavra, que goteja. 
28. O meu amigo era tão

29. de tal modo extraordinário,

30. cabia numa só carta,

31. esperava-me na esquina,

32. e já um poste depois

33. ia descendo o Amazonas,

34. tinha coletes de música,

35. entre cantares de amigo

36. pairava na renda fina

37. dos Sete Saltos,

38. na serrania mineira,

39. no mangue, no seringal,

40. nos mais diversos brasis,

41. e para além dos brasis,

42. nas regiões inventadas,

43. países a que aspiramos

44. fantásticos,

45. mas certos, inelutáveis,

46. terra de João invencível,

47. a rosa do povo aberta...

\section{IV}

48. A rosa do povo despetala-se.

49. ou ainda conserva o pudor da alva?

50. É um anúncio, um chamado, uma esperança embora frágil, pranto infantil no

51. Talvez apenas um ai de seresta, quem sabe.

52. Mas há um ouvido mais fino que escuta, um peito de artista que incha,

53. e uma rosa se abre, um segredo comunica-se, o poeta anunciou,

54. o poeta nas trevas anunciou.

55. Mais perto, e uma lâmpada. Mais perto, e quadros,

56. quadros. Portinari aqui esteve, deixou

57. sua garra. Aqui Cézanne e Picasso,

58. os primitivos, os cantadores, a gente de pé-no-chão.

59. a voz que vem do Nordeste, os fetiches, as religiões,

60. os bichos... Aqui tudo se acumulou,

61. esta é a Rua Lopes Chaves, 546,

62. outrora 108. Para aqui muitas vezes voou

63. meu pensamento. Daqui vinha a palavra

64. esperada na dúvida e no cacto.

65. Aqui nunca pisei. Mas como o chão

66. sabe a forma dos pés e é liso e beija!

67. Todas as brisas da saudade balançam a casa,

68. empurram a casa,

69. navio de São Paulo no céu nacional 
70. vai colhendo amigos de Minas e Rio Grande do Sul,

71. gente de Pernambuco e Pará, todos os apertos de mão,

72. todas as confidencias a casa recolhe,

73. embala, pastoreia.

74. Os que entram e os que saem se cruzam na imensidão dos corredores,

75. paz nas escadas,

76. calma nos vidros,

77. e ela viaja como um lento pássaro, uma notícia postal, uma nuvem pejada.

78. Casas ancoradas saúdam-na fraternas:

79. Vai, amiga!

80. Não te vás, amiga...

81. (Um homem se dá no Brasil mas conserva-se intato,

82. preso a uma casa e dócil a seus companheiros

83. esparsos.)

84. Súbito a barba deixou de crescer. Telegramas

85. irrompem. Telefones

86. retinem. Silêncio

87. em Lopes Chaves.

88. Agora percebo que estamos amputados e frios.

89. Não tenho voz de queixa pessoal, não sou

90. um homem destroçado vagueando na praia.

91. Muitos procuram São Paulo no ar e se concentram,

92. aura secreta na respiração da cidade.

93. É um retrato, somente um retrato,

94. algo nos jornais e na lembrança,

95. o dia estragado como uma fruta,

96. um véu baixando, um ríctus,

97. o desejo de não conversar. É sobretudo uma pausa oca

98. e além de todo vinagre.

99. Mas tua sombra robusta desprende-se e avança.

100. Desce o rio, penetra os túneis seculares

101. onde o amigo marcou seus traços funerários,

102. desliza na água salobra, e ficam tuas palavras

103. (superamos a morte, e a palma triunfa)

104. tuas palavras carbúnculo e carinhosos diamantes. 
O terceiro capítulo da primeira parte do trabalho de Iumna Simon, intitulado "As aporias da participação”, analisa o poema “Mário de Andrade desce aos infernos”. Após identificar a “abertura ao fator novo da comunicação” na “lírica de guerra”, Iumna volta a investigar as tensões drummondianas entre participação política e consciência formal. Uma indicação disto estaria na distância que a linguagem drummondiana guarda da linguagem e dos assuntos cotidianos, evitando a prática radical de uma "poesia

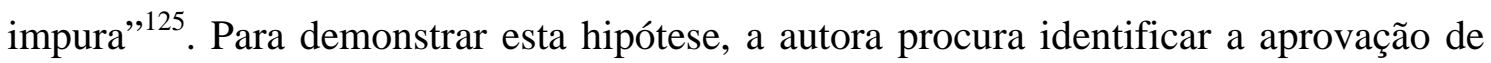
Drummond à obra do amigo Mário de Andrade e, ao mesmo tempo, a enunciação de uma desconfiança quanto ao seu próprio projeto, o que trechos de poemas como “América” e "Cidade prevista” confirmariam.

A presente pesquisa entende não haver convergência plena entre autor e persona(e) lírica(s) na poética drummondiana, e menos ainda entre aspectos imediatamente referenciais e significados conotados. Pode haver elementos de confissão autoral em alguns poemas, e de fato há ${ }^{126}$, mas o gauchismo visa a ampliar as questões do “eu” em direção ao “tu” e ao mundo, principalmente quando a subjetividade hiper ou atrofiada enuncia abster-se de participar para, de fato, incorporar à dimensão interna da forma literária os eventos traumáticos de sua época (como prisões, tortura, censura etc.).

\footnotetext{
125 SIMON, op. cit., p. 109. A autora trabalha com o conceito de "poesia impura", proposto por Michael Hamburguer para definir a poesia situada na Segunda Guerra Mundial. Segundo Iumna, "à penetração no ordinário [pela poesia drummondiana de $A$ rosa do povo], no sentido de se aproximar dos 'homens comuns, numa cidade comum', não corresponde, portanto, uma expressão lingüística equivalente. (...) Por isso, se empreende o risco do engajamento, não chega à prática radical da 'anti-poesia': sua lírica é impura até certo ponto, mais no sentido de busca de uma clareza próxima da prosa, de abertura à informação semântica, como se pôde verificar pela análise das líricas de combate.” (p. 110)

126 Seria impraticável relacionar todas as referências autobiográficas em cada poema da coletânea em nota de rodapé, porque são muitas. Um capítulo inteiro dedicado a apresentar essas referências, além de extensivo, distoaria da problemática central da presente pesquisa. É de certa forma dispensável demonstrar que essas menções autobiográficas, para além do aspecto confessional (jamais recusado em $A$ rosa do povo, apesar do que "Procura da poesia" possa provocativamente sugerir), de fato apresentam função literária (e não raro política) dentro do recurso tipicamente drummondiano do "gauchismo", em especial na poética de $A$ rosa do povo, porque críticos como Afonso Romano de Sant'Anna, Alcides Villaça e Chantal Castelli já o fizeram a contento em seus trabalhos, cujas conclusões são extensivas a toda a obra drummondiana. Por isso, cumpre aqui mencionar apenas um poema, em função de temática significativa. O verso 31 de "Consideração do poema" ("Ao menino de 1918 chamavam anarquista.") pode evocar tanto os "atos gratuitos" (inspirados pela leitura de André Gide), entre os quais atear fogo a um bonde e depositar um pedaço ainda fumegante à mesa da refeição, presidida pelo "pai-coronel", quanto a resposta aos colegas do Colégio Anchieta, quando do seu ingresso ao internato, justamente em 1918 (perguntado sobre a sua filiação política, Drummond responde: "Eu sou anarquista"), ou ainda a sua expulsão daquele instituto jesuíta por "insubordinação mental". (CANÇADO, Os sapatos de Orfeu, p. 63-79) A ampliação desse aspecto autobiográfico no sentido do heterobiográfico mas também do literário e do político compõe a própria estratégia formal do poema.
} 
Assim, a participação não é apenas (nem preferencialmente) uma questão de enunciado, porque se faz, sobretudo, por uma espécie de "sentimento íntimo”"127. E não é possível perder de vista que o plano em que as “inquietudes” de fato efetivam a redenção de “eu” e “mundo” é o da expressão formal.

Este poema, aparentemente, são "versos sobre acontecimentos” (a morte de Mário de Andrade em 1945). No entanto, ainda que Carlos Drummond de Andrade preste uma homenagem emocionada ao amigo, a consciência formal direciona o processo significativo para um sentido mais amplo que o da simples confissão subjetiva. Embora a expressão do luto mobilize recursos semânticos e estilísticos, o significado último do poema é a confirmação do projeto poético engajado de $A$ rosa do povo, marcado pela pluralidade estético-conceitual, pela participação da linguagem poética nos eventos cotidianos com vistas a transcendê-los e pela recusa do monumental. Não por acaso, este é o único poema da coletânea em que há a expressão "rosa do povo”. O poema, como a própria expressão-título, é uma espécie de síntese metapoética. Ao mimetizar aspectos da obra plural marioandradiana, o poema identifica-se com o seu aspecto integrativo, a exemplo do personagem-amigo, espécie de escala para a qual converge uma multiplicidade vertiginosa de relações artísticas.

Assim como em “Áporo” e “Anúncio da rosa”, neste poema a “flor” também assume o sentido de "impasse", na medida em que figura a morte, o luto e a perda de significado. A morte é representada por imagens que sugerem, por metonímia, o contato físico, ou sinestésico, de todo modo traumático com o cadáver do artista (a "pele do amigo”, o “frio”, a “cor”, o silêncio”, a “barba que deixou de crescer”). O luto é expresso pela fragmentação dos significados (são diversas as imagens de amputação) e, sobretudo, das formas (há quatro seções em que predominam versos longos com pontuação truncada e enjambements, como que em reforço ao campo semântico: “partiram-se”, “cacos”, “explosivo”, “despetala-se”, “esparsos”, “amputados”,

\footnotetext{
${ }^{127}$ Referimo-nos à expressão de Machado de Assis no ensaio supracitado.
} 
“destroçado”). A perda de significado representa-se pelas figuras da “escuridão” e do "silêncio".

Este “impasse” se anuncia da maneira mais dramática entre os versos 48-51 e 84-98, e não por acaso se vê desfeito, em ambos os momentos, pelo "mas”. Esta postura adversativa confirma a perda e a finitude em termos vitais, “concretos”, com a imagem da decomposição biológica (“o dia estragado como uma fruta”) e a alegoria (“a rosa do povo despetala-se”); entretanto, termina por reafirmar a confiança no projeto artístico (com “uma rosa se abre, um segredo comunica-se” e com "ficam tuas palavras / (superamos a morte, a palma triunfa)”).

A figuração da obra do amigo, entremeada pela expressão do luto, comporta a mimese de aspectos estilísticos, além da paráfrase de versos e da referência à biografia do artista. Com isso, muito embora o poema enuncie dolorosamente a perda do amigo, termina por evocar a sua presença simbólica de maneira muito expressiva, o que permite a afirmação do penúltimo verso para além duma retórica vazia de necrológio.

Ora o eu lírico se dirige ao amigo morto como a um "tu", configurando uma interlocução, ora ele narra o seu contato com o amigo morto, ou descreve a sua obra, tornando-o uma terceira pessoa de quem se fala, e cujo atributo central é, justamente, a interlocução. Por fim, o eu lírico incorpora a primeira do plural ao seu discurso e retoma a interlocução com o “tu”. Deste jogo de aproximações e distanciamentos, resulta a consciência de que a obra artística apresenta uma dimensão necessariamente coletiva, plural, mesmo quando, paradoxalmente, reforça-se a subjetividade da escala lírica.

A casa da "Rua Lopes Chaves, 546” é a figura, a um tempo biográfica e metafórica, da escala de uma obra para a qual convergem pessoas e espaços diversos. Esse espaço, a exemplo da própria trajetória do eu lírico neste poema e em toda a coletânea, contrai-se ou distende-se sempre de maneira integrativa, reunindo os mais diversos interesses cognitivos e as mais diferentes manifestações artísticas sob a escala da convivência cotidiana.

O sentido integrativo da obra marioandradiana é figurado no poema de maneira ambivalente. De um lado, a fragmentação temático-formal do poema expressa a dor e o impasse; de outro, atribui à obra do amigo-persona o caráter plural e a capacidade de sobrevida e integração. Nesse sentido, este poema realiza uma espécie de síntese de toda a metapoesia de A rosa do povo e, por extensão, expressa empaticamente a coerência da própria coletânea. São possíveis diversos paralelos entre este e os demais poemas da 
coletânea, dentre os quais destaca-se "Nosso tempo", não apenas em virtude da fragmentação temático-formal, mas também por conta de que, sob a persona "Mário de Andrade”, ou “rosa do povo”, há a tão desejada "síntese”:

10. Visito os fatos, não te encontro.

11. Onde te ocultas, precária síntese,

12. penhor de meu sono, luz

13. dormindo acesa na varanda?

14. Miúdas certezas de empréstimo, nenhum beijo

15. sobe ao ombro para contar-me

16. a cidade dos homens completos.

De fato, o recurso à fragmentação temático-formal percorre toda a coletânea, e figura o sem-sentido da subjetividade lírica frente à sociedade industrial capitalista e seus subprodutos, como a guerra, a publicidade, o nazifascismo etc. Por outro lado, através do gauchismo e de recursos figurativos múltiplos (que as análises anteriores se esforçaram por demonstrar), a desfiguração subverte-se pela transfiguração, de modo que a denúncia concorre para a experiência estética de sua superação, cujos significados adquirem sentido político, entre diversos outros sentidos.

Essa convergência entre estética, política e subjetividade lírica também encontra-se em "Mário de Andrade desce aos infernos”. A subjetividade dorida do poeta (cuja persona empática se amplia, por sob a figura do “amigo-obra”, em direção a “Cézanne e Picasso, os primitivos, os cantadores, a gente de pé-no-chão, a voz que vem do Nordeste, os fetiches, as religiões, os bichos... tudo”, “amigos de Minas, do Rio Grande do Sul, gente de Pernambuco e Pará, todos os apertos de mão, todas as confidências”); a homenagem à obra marioandradiana (significativa em relação ao Modernismo como o poema “No meio do caminho”); o espraiamento dos versos; todas essas dimensões estético-conceituais reforçam a experiência da pluralidade, e este é o sentido profundamente engajado da poética drummondiana, o que reforça, expressivamente, o significado multívoco de "povo”, ou "nação”, que este poema, bem como toda a coletânea, comporta. Considerando-se o contexto literário da coletânea e também o contexto extra-literário em que a coletânea se engaja, sem entretanto reduzirse à temporalidade da crônica, o poema assume uma importância política fundamental.

A seção III, toda escrita em redondilha maior, com a exceção de dois versos significativos, figura o "meu amigo" integrado a diversas paisagens brasileiras, numa 
espécie de geografia afetiva que parte da escala mínima da “carta” para escalas progressivamente maiores, que culminam

40. nos mais diversos brasis,

41. e para além dos brasis,

42. nas regiões inventadas,

43. países a que aspiramos

44. fantásticos,

45. mas certos, inelutáveis,

46. terra de João invencível,

47. a rosa do povo aberta...

Essa escala de "saltos", em que pese a sua rigorosa "liberdade" inventiva, totalmente de acordo com a problemática do poema, cria uma empatia muito grande entre a figura de "Mário de Andrade" e a figura do "poeta do finito e da matéria" (de “Consideração do poema”) através de uma métrica de tradição popular, e essas figuras coincidentes promovem a identidade - mediada - entre as instâncias intercambiáveis do discurso (autor(es), obra(s) e público(s)). A imagem da "rosa do povo aberta..." condensa esse movimento de ampliação da subjetividade no sentido de outras subjetividades e espaços-tempos, em que a coincidência não se faz por redução, mas por intersecções. Trata-se de um movimento que, embora comporte a figuração de eventos objetivos, filtra-os e transfigura-os pela mediação da subjetividade cujas necessidades volitivas integram os significados concretos às possibilidades simbólicas. A coerência desses “saltos” subjetivos, aqui, se faz graças à adequação entre métrica e problemática.

Trata-se da criação de identidades. Identidade entre autores, entre obras e entre públicos, para além das fronteiras e das convenções. A identidade múltipla se faz por “saltos” e por “fantasias”, características intrínsecas à idéia de "liberdade” que se expressam significativamente nos dois únicos versos em que a métrica deixa a redondilha, como que em reforço ao seu caráter de ficção. O "nacional” e o "popular” ganham um sabor vertiginosamente polissêmico, transcendendo os significados préestabelecidos pelo "real concreto". A geografia física e a geografia humana ressignificam-se por uma espécie de geografia afetiva em que o território nacional “concreto" se transforma em "brasis” (assim, no plural e com minúscula), termo que se duplica (v. 41-42) como se a sugestão de pluralidade fosse, na concreção material do signo lingüístico, insuficiente para representar esse salto em direção ao simbólico polissêmico. Desta forma, a invenção do nacional comporta o paradoxo de desfazer 
fronteiras e adquirir um significado universal, transcendente e, sobretudo ficcional. Nada mais agressivo frente à estreiteza chauvinista do fascismo ${ }^{128}$.

Que esta pluralidade de natureza conceitual, a promover a convergência entre estética e política, se condense na imagem da "rosa do povo aberta...”, e que esta imagem-síntese se transforme em título da coletânea, agregando à escala lírica a superação do “impasse” por meio da dimensão simbólica, isto parece reforçar a hipótese de que a poética drummondiana de 1945 tem na dimensão formal o seu verdadeiro sentido de engajamento, com ser integrativa.

128 Note-se que esta preocupação com a estreiteza do "nacional", discutida por Mário de Andrade nas suas cartas a Drummond (publicadas pelo poeta em Lição do amigo), está presente na obra drummondiana desde o seu primeiro livro de poemas, Alguma poesia, do ano-marco 1930 (veja-se, entre outros, "Também já fui brasileiro"). Em toda a obra, entretanto, o poema mais significativo a esse respeito talvez seja "Hino nacional", de Brejo das Almas, publicado em 1934 


\section{SEGUNDA PARTE}

A prosa do poeta 


\title{
CAPÍTULO 4
}

\section{NA PRAÇA DE CONVITES}

\author{
(ÁPORO)
}




\section{CAPÍTULO 4 - Na praça de convites (áporo)}

Refratário aos conteúdos mais positivos da poética modernista (incluída a conquista de uma ordem pessoal, que Manuel Bandeira obtinha para sua outra melancolia), Drummond valeuse, no entanto, da pluralidade dessas inflexões recém-conquistadas, fazendo delas uma espécie de arco estilístico cuja raiz obstinada fosse um sujeito de muitas faces, verdadeiro em todas $e$ incompleto a cada uma.

(Alcides Villaça, Lendo poetas brasileiros)

\section{1}

Procuramos demonstrar, na Primeira Parte, que o primeiro poema de A rosa do povo traz em si, como um microcosmo, a experiência poética de toda a coletânea, na medida em que a escala lírica é um fator coesivo e a pluralidade vertiginosa de temas e estilos é um fator, ainda que paradoxal, de coerência. A figuração de fragmentos temático-formais, à primeira vista pouco coesos, transfigura-se numa multiplicidade inesgotável de combinações e recombinações, de tal maneira que é esteticamente possível vivenciar, a um tempo, a precariedade reificante e a plurissignificação. A inquietação subjetiva entre a interioridade e a exterioridade instaura um processo a tal ponto dinâmico que se torna impossível identificar a pura interioridade ou a pura exterioridade, uma vez que há contaminação recíproca. Esse dinamismo permanente torna-se denúncia dos estados de reificação e, ao mesmo tempo, redenção de "eu” e de “mundo”, conflituosos mas complementares.

Verdadeiro pensamento poético, esse sistema significante não se capta senão como processo, e pode-se conceituar como “inquietudes". Qualquer recorte, seja temático e / ou formal, não dará conta de compreendê-lo em sua ambivalência de mimese e transfiguração, caso perca de vista a importância, não da forma em si, mas da função que a forma adquire no contexto mais amplo do pensamento poético 
drummondiano. Nesse contexto, a forma, em relação indissociável com o fundo, ressignifica-se em caráter permanente e dinâmico, de tal modo que não há preocupação predominantemente "formal” ou predominantemente "temática”, porque a "forma" torna-se "tema" pelo recurso onipresente da metapoesia, que também converte todos os “temas” em "forma”, veja-se a figuração da “escrita” como trabalho social, desfigurando-se como reificação mas transfigurando-se como fator humanizante. Forma e fundo, embora guardem relativa independência entre si, não se captam, em A rosa do povo, como instantes exclusivamente sincrônicos, ou então como instâncias exclusivamente diacrônicas, e sim como interface em que texto e contexto contracenam.

Em A rosa do povo, a clareza metalingüística não se restringe à metapoesia, porque não há, na coletânea, forma desvinculada de rigor expressivo. Em última instância, pode-se mesmo afirmar que toda a coletânea é, de certa forma, metalingüística, na medida em que o engajamento depende de figurar-se o trabalho poético como instância social, cuja materialidade de signo não se completa nem na experiência estética significante, nem na experiência social do significado. Do jogo complexo entre coesão (lirismo) e coerência (pluralidade), resulta um pensamento poético assentado no rigor da expressão formal, em que a pluralidade não estabelece nenhum fragmento que não se articule organicamente com o todo lírico. O apuro formal em qualquer poema, independentemente de diferenças estilísticas, é índice de participação, a um tempo estética e política. Ao abordar a construção dos significados na metapoesia, compreende-se a coerência estética de A rosa do povo e o sentido de seu “engajamento”, cuja fundamentação reside na escala lírica.

A partir desse momento de compreensão estética, e não antes, é possível refletir com propriedade sobre os núcleos temáticos presentes na coletânea, e sobre seus significados. (É preferível falar em “núcleos temáticos”, e não “assuntos”, visto que não há referência na coletânea que se desvincule do adensamento lingüístico, próprio à linguagem poética.)

O "indivíduo", em A rosa do povo, muito mais do que um "assunto", é uma problemática fundamental, de que decorre a pluralidade de temas e formas. Da problemática individual é que decorrem os significados do "engajamento” e, por isso, perceber "eu” e "mundo" como aspectos dicotômicos na poética drummondiana de $A$ rosa do povo é, não apenas impróprio, mas incorreto. Se, no contexto objetivo a que os poemas se referem, essa dicotomia é um fato, no contexto poético, a “antinomia” não apenas desfigura-se como, sobretudo, transfigura-se. 
“Consideração do poema” promove "saltos” estilísticos de estrofe a estrofe. Mudanças bruscas de perspectivas promovem a experiência da pluralidade em seu sentido analítico (na microperspectiva) e sintético (na macroperspectiva). Lido estrofe a estrofe, o poema figura a experiência das suas unidades expressivas em direção a questões mais amplas. Visto como um todo coerente, suas descontinuidades revelam-se, de fato, metonímicas, de modo que a parte evoca o todo e o todo evoca as partes, prevalecendo a percepção analógica por sobre a linearidade analítica. Como não há linearidade na macroperspectiva, cada fragmento significante é tão significativo do todo quanto insuficiente em si. E como a microperspectiva revela-se um aspecto da totalidade, cada significado particular apresenta-se sempre provisório.

Do mesmo modo, cada poema, em A rosa do povo, não tem, em si, uma significação que não seja provisória, o que não o invalida como parte, mas o enriquece como aspecto do todo. Não apenas "Procura da poesia”, mas todo poema de A rosa do povo desdobra um ou mais aspectos, temáticos e / ou formais, propostos por “Consideração do poema”, cujo fator de coesão e de coerência são as “inquietudes”. Nesse sentido, é muito significativo que os dois poemas, introdutórios e complementares, apresentem paralelismos entre si, e também em relação a "Poema de sete faces”, o primeiro poema do primeiro livro de Drummond.

No ensaio "Sete faces de um poema"129, Alcides Villaça busca compreender o fenômeno literário do gauchismo drummondiano a partir da leitura do "Poema de sete faces”, analisado em seus aspectos estéticos e interpretado em seus sentidos psíquicos e sócio-culturais, tomando a coletânea de 1930 (Alguma poesia) como contexto imediato do poema e considerando toda a obra drummondiana como contexto mediato. Depreende-se do ensaio que o lirismo do "Poema de sete faces" é o fundamento de

${ }^{129}$ Alcides VILLAÇA, “Capítulo drummondiano”, in Lendo poetas brasileiros. 
Alguma poesia e esclarece diversos pontos de toda a obra drummondiana, em especial quanto à pluralidade de temas e de formas.

Compondo uma espécie de auto-retrato poético em que elementos autobiográficos se expressam sob uma consciência artística rigorosa e, assim, transfiguram-se, o poema serve-se de personae segundo perspectivas diversas e justapostas, como se houvesse uma espécie de critério de permanente descontinuidade na pluralidade de falas, de inflexões e em outros elementos estilísticos. Essas oscilações na voz lírica, entre o confessionalismo e o distanciamento crítico-irônico, criam uma identidade complexa e paradoxal para o "individuum”. Plural, ele se vê diante de possibilidades muitas vezes contraditórias, e sempre problemáticas, não apenas no campo estético, como também histórico. Condenado à liberdade, e em descompasso diante do mundo, o "individuum" lírico situa-se no contexto da modernidade sob o ideal mitopoético da completude, invariavelmente em contraste com a percepção de sua impossibilidade objetiva. O sentido das experiências figuradas é a percepção da incompletude, sob o desejo de integridade.

Enquanto a descontinuidade permanente sugere a disparidade como imediata impressão de leitura, a escala lírica estabelece um fator de coesão, e desse jogo entre pluralidade e coesão, depreende-se, já no primeiro poema da coletânea, a amplitude de todo o arco estilístico drummondiano. Nele, podem-se perceber:

1) as conquistas estilísticas da "fase heróica” do Modernismo, aprofundadas e sintetizadas pela negatividade crítica drummondiana;

2) a gênese da persona poética gauche, de filiação baudelaireana mas com o sentido modernista de diluir o trágico no prosaico;

3) a instabilidade como padrão;

4) a revelação da modernidade pela figuração lingüisticamente cifrada;

5) a oscilação entre um ponto de vista auto-suficiente, em que o eu desdenha do mundo, e outro ponto de vista, em que a timidez, se por um lado predispõe à inação, por outro revela o desejo do encontro.

Multiplicando-o [o 'individuum'] em distintas faces a partir de um simulacro de autobiografia, Drummond dota o seu sujeito da identidade complexa de quem está sempre fora de alguma ordem de expectativa, valendo-se para isso de uma expressão que tampouco repousará na exclusividade de um estilo. (...) Numa encruzilhada histórico-estética em que múltiplos e contraditórios valores parecem disponíveis, a falta do rosto pessoal é 
preenchida por uma sucessão de seus esboços, desierarquizando-se planos $e$ temas, sensações e sentimentos, conceitos e imagens. (...)

Tal liberdade Drummond a exercita com o 'grão de angústia' de seu humor crítico; integra-a numa biografia possível, a que não faltam premonições dos grandes temas de sua poesia. O leitor mais íntimo de sua obra reconhecerá neste poema, correndo sob a linguagem, uma história de motivos bem familiares: a maldição original (como a lançada pelos ancestrais no extraordinário 'Os bens e o sangue'), a inquietude das paixões amorosas (como em 'Tarde de maio' ou 'Campo de flores'), a perda da ordem provinciana (como em 'Confidência do itabirano'), o contraponto entre o ritmo da intimidade e o da cidade grande (como em 'A bruxa'), os dilemas da classe média e do poeta funcionário público (como em 'A flor e a náusea'), a culpa íntima e irresgatável (como em 'A mão suja'), a ilusão da decantada conciliação brasileira (como em 'Hino Nacional'). ${ }^{130}$

De certa maneira, os fatores de coesão (escala lírica) e de coerência (pluralidade temático-formal), que se identificam na gênese do gauche em Alguma poesia, estão presentes também em “Consideração do poema”, de A rosa do povo, não como aspectos acessórios, mas como seu fundamento. Admitindo-se a "participação política” como um fator de "novidade” na lírica drummondiana após Sentimento do mundo (de 1940), é importante notar que esse fator não interfere nem na escala lírica, nem na pluralidade temático-formal, nem tampouco no aspecto dialogal que cada "momento" drummondiano configura em relação à obra, dimensão que, n’A rosa do povo, em especial, sublinha-se. Assim, se houver “novidade”, isto se dá no plano do “assunto”, e não altera o fundamento lírico drummondiano.

Entretanto, parece temerário afirmar que em Alguma poesia a "política”, ou não esteja presente, ou então seja irrelevante, em razão do individualismo drummondiano. Naquela coletânea, há poemas como “Outubro 1930” e “Também já fui brasileiro” que, minimamente contextualizados, pressupõem, senão a "tomada de partido", ao menos o envolvimento em questões candentes do período, a despeito (ou, antes, em função) da persona lírica. Ademais, não é adequado conceituar “individualismo” como algo necessariamente contraposto a "participação política”, quando, ao contrário, pode configurar uma estratégia de combate à despersonalização que a, assim chamada, “política” (as questões institucionais) empreende no contexto industrial ${ }^{131}$. De todo

\footnotetext{
${ }^{130}$ Idem, ibidem, p. 28-29.

131 Durante a Guerra Civil Espanhola (1936-1939), um sem-número de pessoas, oriundas de todas as partes do mundo, participou das Brigadas Internacionais, muitas delas sob perspectivas anarquistas, para as quais os interesses coletivos não anulavam, antes pressupunham, a vontade individual. Havia correntes anarquistas que radicalizavam a questão do indivíduo, colocando-a acima dos interesses coletivos (cf. James JOLL, Anarquistas e anarquismo, e George WOODCOCK, Os grandes escritos anarquistas). Segundo as interpretações anarquistas dos conflitos espanhóis, os homens ligados a Stálin participaram, de fato, contra os republicanos
} 
modo, ainda que não seja pertinente aprofundar, aqui, a discussão sobre os significados políticos da(s) perspectiva(s) lírica(s) nos primeiros momentos drummondianos, é necessário relativizar a dicotomia entre “individualismo” e “engajamento” antes e depois de Sentimento do mundo, porque esse pressuposto questionável reduz a problemática complexa do indivíduo na modernidade a uma oposição simplista, empobrecedora e, sobretudo, anacrônica. A "novidade do engajamento" não deve ser critério suficiente para que se estabeleçam rupturas absolutas na poética drummondiana $^{132}$.

A “política”, como “assunto”, sem dúvida, contrapõe-se antinomicamente à “individualidade" no contexto do capitalismo industrial e, sobretudo, segundo as perspectivas totalitárias $^{133}$ - mas isto não ocorre no universo estético drummondiano de A rosa do povo. Da mesma maneira que outros aspectos “extra-literários”, a “política” desfigura-se / transfigura-se como elemento dramático, e enquanto o efeito imediato disso é a impressão de disparidade entre "indivíduo" e "política”, o efeito mediato é o da contaminação recíproca entre eu e mundo, de tal modo que a "política" impregna-se de aspectos da intimidade, e os aspectos mais íntimos “politizam-se”, não procedendo, portanto, a dicotomia público / privado, ou intimidade / exterioridade, no âmbito estético do gauchismo drummondiano. Tal é o fundamento do lirismo (também) na poética de A rosa do povo.

e, em especial, as milícias anarquistas, e é ao bolchevismo, em especial ao stalinismo, que se pode imputar a defesa dos interesses coletivos às custas da personalidade individual (cf. "El movimento libertario español", in Cuadenos de Ruedo Ibérico, 1974). O totalitarismo stalinista, ao reforçar a autoridade do Partido e a "ditadura do proletariado", mediante o sacrifício das experiências libertárias, não apenas nas vanguardas artísticas mas também na educação experimental, tornou-se o grande responsável pela identificação entre absenteísmo e individualismo, o que veio a se consolidar, durante a Guerra Fria, no âmbito de algumas concepções de esquerda.

$132 \mathrm{O}$ próprio Drummond contribuiu para essa abordagem, na medida em que afirmou: "Meu primeiro livro, Alguma Poesia (1930), traduz uma grande inexperiência do sofrimento e uma deleitação ingênua com o próprio indivíduo. Já em Brejo das Almas (1934), alguma coisa se compôs se organizou; o individualismo será mais exacerbado, mas há também uma consciência crescente da sua precariedade e uma desaprovação tácita da conduta (ou falta de conduta) espiritual do autor. Penso ter resolvido as contradições elementares da minha poesia num terceiro volume, Sentimento do Mundo (1940)." ("Autobiografia para uma revista", in Confissões de Minas, p. 71-74.)

133 “O Estado moderno de Miguel Reale propõe-se a uma discussão eminentemente doutrinária. Reale ocupa, à época, o cargo de chefe do Departamento Nacional de Doutrina da Ação Integralista Brasileira. Neste livro, o autor procura apontar de que modo o fascismo conserva e transforma aspectos de diferentes teorias e as reorganiza em uma nova síntese. Diferente do sindicalismo soreliano, eminentemente antiestatal, o fascismo conceberia o Estado como organismo moral, político e econômico superior aos indivíduos isolados ou aos agrupamentos que compõem a nação. O sindicalismo colocaria o sindicato no lugar antes ocupado pelo indivíduo, acabando por criar uma nova dualidade, representada pela relação sindicato-Estado. O fascismo, diferentemente do sindicalismo, teria uma concepção ética do Estado, já que representaria a concepção imanente da nação, Neste caso, a soberania (afirmação da capacidade jurídica) pertenceria à nação organizada, ou seja, ao Estado. Atribuir ao Estado a superioridade de seus fins sobre os fins do indivíduo seria a compreensão verdadeira da soberania." (Lúcia Lippi OLIVEIRA et alli, Estado Novo: ideologia e poder, p. 18) 
Na Primeira Parte deste estudo, procuramos entender, em "Consideração do poema”, algumas questões temático-formais que se desdobram no poema seguinte, “Procura da poesia”, e que fundamentam a própria coletânea. Na problemática da “flor”, por exemplo, figuram-se aspectos do contexto extra-literário que, desfigurados por recursos como a ironia ou a paródia, terminam por (d)enunciar a reificação; mas, ao mesmo tempo, é possível perceber, nesse movimento figurativo, a transfiguração da precariedade, e então a “flor”, mais do que alegoria da insuficiência, torna-se símbolo de sua superação. Nesse sentido, a expressão “rosa do povo”, para além de um conjunto de significados provisórios, transforma-se na própria capacidade de ressignificação. E o fundamento lírico desse dinamismo figurativo, como se vê, é a pluralidade temáticoformal sob a escala subjetiva das "inquietudes".

A subjetividade drummondiana em A rosa do povo, dessa perspectiva, é uma característica de estilo, em que a(s) persona(e) do Gauche exprime(m)-se por uma identidade formalmente plural e psiquicamente complexa, garantindo a uma tal multiplicidade de formas e problemas a coesão do “individuum” lírico. Vale, portanto, acompanhar alguns percursos subjetivos ao longo da coletânea, identificando a pluralidade sem perder de vista a escala lírica, e compreendendo, nesse jogo entre coesão e coerência, os possíveis significados do “engajamento”.

\section{5}

Em A rosa do povo, um sempre mesmo personagem manifesta-se sob uma vertiginosa pluralidade de personae. Em alguns momentos, o Gauche multiplica-se por diversos papéis, cada qual funcionando como aspectos de uma mesma problemática, ou então os índices de “função emotiva” ocultam-se ao máximo, tornando-se mesmo elípticos, e, ainda assim, é da identidade complexa do Gauche que se trata. Não há nenhum poema neste livro que não seja lírico. Mesmo naqueles em que se evidencia a estrutura dramática, como em “Noite na repartição”, percebem-se as inquietações líricas como fundo. (Nesse poema, o drama do escritor-funcionário, a um tempo tipicamente 
drummondiano e característico de toda uma geração ${ }^{134}$, encena-se através de objetos que personificam o universo da repartição pública e contracenam, dialogalmente, numa paródia da linguagem dramatúrgica de um cômico irresistível, que, entretanto, expressa o dilaceramento da personalidade lírica com maestria.)

Nessa escala lírica, plural mas coesa, o Gauche oscila entre a altivez e a paralisia, sendo mais freqüente uma espécie de ponto intermédio, que consiste na figuração de uma rebeldia, a enunciar o reconhecimento da sua própria precariedade, diante dos obstáculos percebidos. De uma maneira ou de outra, todo o livro figura inúmeros impasses, muito embora trate de conotar a sua superação.

A “participação” drummondiana em "eventos”, como a guerra mundial, marca os momentos mais altivos da coletânea, mas basta examiná-los de perto para entrever que esse “engajamento” figura-se mais “imaginário” do que “factual”. O lugar do eu demarca-se muito claramente, e, ao fazê-lo, estabelece uma escala lírica que se previne contra as dimensões do heróico e do monumental. "Participar”, portanto, dos eventos objetivos não requer, antes pressupõe, uma radical subjetividade, que vem a ser o próprio fundamento poético do lirismo drummondiano.

\section{6}

O assim chamado "bloco do engajamento"135 comporta oito poemas, dispostos consecutivamente em A rosa do povo: “Notícias”, “América”, “Cidade prevista”, “Carta a Stalingrado”, “Telegrama de Moscou”, "Mas viveremos”, "Visão 1944” e "Com o russo em Berlim”. Excetuando-se os três primeiros, tem-se a chamada "lírica de guerra” (de “Carta a Stalingrado” a “Com o russo em Berlim”), que é objeto de análise do referido estudo de Iumna Simon.

Embora a descrição dos procedimentos destes três últimos poemas ("Mas viveremos", "Visão 1944" e "Com o russo em Berlim") tenha sido bem simplificada, serve, pelo menos, para comprovar o fato de que nos momentos de maior empenho participante o discurso ganha em "informação semântica": o jogo entre as funções emotiva, conativa e referencial é bem desenvolvido, e a estrutura sintática baseia-se em recursos ampliativos, repetitivos e

\footnotetext{
${ }^{134}$ Cf. Sérgio MICELI, Intelectuais e classe dirigente no Brasil.

135 Iumna Simon, Drummond, uma poética do risco.
} 
acumulativos, todos a serviço da abertura do discurso à comunicaçãorevelação. De tal forma que a configuração do discurso poético obedece à "vontade semântica" do poeta, cuja intenção é atingir - ou "atravessar" - o destinatário da mensagem e estabelecer o circuito completo da comunicação. Haja vista a alta freqüência, nos textos componentes do bloco das "líricas de guerra", de "sentenças-registro" (do tipo "Trabalhadores, uni-vos...", “o general com seu capote cinza", "a fila de judeus de roupa negra”, "a massa de silêncio concentrada / (...) esperando a passagem dos soldados”, etc... etc...) que conferem aos textos um acentuado grau de "informação documentária". ${ }^{136}$

Segundo o estudo, o ganho que os poemas “engajados” apresentam em “informação semântica” implica perda em termos de "informação estética”, o que estabelece uma “tensão” (“oposição”, “antinomia”) em relação aos poemas do “bloco do fechamento", cuja característica é o exato inverso: perda em "informação semântica” com ganho em "informação estética”, de tal modo que esta dicotomia estabelece um movimento pendular entre “participação” nos eventos objetivos (em termos de procedimentos lingüísticos sobretudo “referenciais”) ou ruptura com este caráter "referencial” (quando a linguagem, circunspecta, refere-se a si própria, negando outros referenciais que não a própria mensagem). Como resultado dessa oscilação, haveria a diversidade de procedimentos temático-formais, em cuja riqueza, entretanto, predominariam as tônicas da participação social, ou da circunspecção lingüística, ou, então, um equilíbrio tenso entre estes contrários.

Nesse sentido, os poemas "predominantemente referenciais" comportariam uma subjetividade acentuada, não apenas em termos de "função emotiva”, mas também em termos de "função conativa”, uma vez que "eu” e "tu” são chamados a interferir nos eventos, enquanto nos poemas “predominantemente circunspectos”, ao contrário, raros seriam os índices de subjetividade. O significado desse processo antinômico seria um esforço poético consciente de sua própria precariedade, quanto a equilibrar “participação política” e “participação estética”, num contexto social em que essa dicotomia implica, ou perda de poeticidade, ou então perda de envolvimento imediatamente histórico.

Entendemos, contudo, que o instrumental analítico predominante no estudo citado (qual seja: a teoria do Formalismo), não parece dar conta do fundamento poético de A rosa do povo, cuja coesão lírica serve-se da pluralidade de falas e inflexões, de tal modo que, sob a diversidade de manifestações subjetivas, mesmo quando parece ocorrer

\footnotetext{
${ }^{136}$ Idem, ibidem, p. 107-108.
} 
a despersonalização, identifica-se, ao contrário, a escala onipresente do lirismo, cuja percepção, entretanto, não se alcança quando se desconsidera a dinâmica entre texto e contexto.

Identificar a dimensão subjetiva na "lírica de guerra" e as relações dialogais que ela estabelece com outros poemas em $A$ rosa do povo pode contribuir para a compreensão do processo significante na coletânea, bem como para o entendimento do que vem a ser "participação".

Do poema "Notícias” ao poema "Com o russo em Berlim”, pode-se perceber uma espécie de "calendário de guerra”, cujo marco fundamental é a Batalha de Stalingrado ${ }^{137}$. De fato, lidos os poemas com preocupações sobretudo “temáticas”, percebe-se uma cronologia em que os poemas consecutivos "Carta a Stalingrado" e “Telegrama de Moscou” configuram um marco, com “antes” e “depois”. “Antes”, isto é, nos três poemas anteriores (“Notícias”, “América” e "Cidade prevista”), predomina a percepção lírica, geográfico-afetiva, do insulamento, em que não é possível obter notícias ${ }^{138}$ sobre territórios longínquos ${ }^{139}$, a partir do lugar em que o eu percebe-se isolado. Em razão dessa distância e da incomunicabilidade, “imagina-se” (isto é, produzem-se imagens, figura-se) ${ }^{140}$. O lugar de onde se fala (a “praia”, a "beira de um rio”, a “cidadezinha de Minas”) jamais se confunde com os lugares “imaginados”, a despeito do impulso erótico, que predispõe ao encontro, mas que se percebe muito claramente tolhido (silenciado, censurado).

A esse “antes”, corresponde um “depois”, entremeado pelos dois poemas que “imaginam” a Batalha de Stalingrado (“Carta a Stalingrado” e “Telegrama de

${ }^{137}$ Murilo Marcondes de MOURA, Três poetas brasileiros e a Segunda Guerra Mundial, p. 25.

138 A "temática" das incomunicabilidade é uma constante em diversos poemas de $A$ rosa do povo, e também em poemas como "Notícias de Espanha", da coletânea Novos Poemas, de 1948. Entendida no contexto de censura, torturas e prisões, como era o caso de Brasil, Espanha e diversos países nazi-fascistas ou filofascistas nas décadas de 1930 e 1940, a temática da incomunicabilidade (em que também se inserem os poemas do "bloco do fechamento") termina por assumir características "referenciais", como se pode notar no poema "Áporo". 139 Os territórios enunciam-se "longínquos" em termos de espaço (porque efetivamente distantes) e em termos de escala (porque figuram-se muito mais amplos que o lugar psíquico do eu, e portanto enunciam-se inatingíveis).

140 Note-se que não há, propriamente, em nenhum desses poemas, "referências" a eventos objetivos, mas, ao contrário, especulações de natureza ficcional, imagética. 
Moscou”). Em “Carta a Stalingrado”, enuncia-se a ruptura com a "escuridão”, isto é, com a falta de "notícias" (ou "informações" sobre a guerra e os conflitos implicados). Mas não se deve perder de vista que o contentamento do eu lírico é devido, não à participação direta nos eventos, tampouco a informações fartas, mas a “jornais” e “telegramas”, de modo que a mediação (“entre mim e os mortos há o mar / e os telegramas”141) mantém-se em termos de precariedade, muito embora enuncie-se o esgarçamento do "silêncio"142.

Cabe notar a presença do contexto "extra-literário” na organização textual, uma vez que em 22 de agosto de 1942, praticamente ao mesmo tempo em que a Batalha de Stalingrado se inicia, o Brasil declara guerra ao Eixo, e, portanto, os vínculos identitários entre o Estado Novo e o nazi-fascismo passam a revelar-se contraditórios, e, por força de pressões dentro e fora do país, tendem a esgarçar-se ${ }^{143}$. E a construção

\footnotetext{
141 Referência à primeira estrofe do poema "Notícias":

1. Entre mim e os mortos há o mar

2. e os telegramas.

3. Há anos que nenhum navio parte

4. nem chega. Mas sempre os telegramas

5. frios, duros, sem conforto.
}

${ }^{142} \mathrm{Na}$ "lírica de guerra", não há referências imediatas a eventos objetivos. A preocupação formal é sempre um plano intermédio entre a imagem e a conjuntura, e sempre a maneira de dizer importa mais do que aquilo que propriamente se diz (ou, por outra: não há informação factual, porque a maneira de dizer é parte integrante do que se diz). Disso, são índices a linguagem cifrada e as inflexões, mais alusivas que imediatamente referenciais (de resto, "cifras" e "alusões" são temáticas mais importantes que a própria "guerra"). O discurso lingüístico, por mais que se mostre evidentemente "referencial", é propriamente denso, e, portanto, "poético".

143 “Em 1943 escrevi a Drummond sem conhecê-lo, pedindo descaradamente colaboração para uma revista de jovens de que eu fazia parte. Ele respondeu com extraordinária cortesia, mandando palavras de estímulo e alguns poemas admiráveis, que depois apareceriam quase todos em Rosa do povo. Escolhemos três, que só foram sair dali a um ano, porque a revista passou por longo eclipse. Mas antes de acabar para sempre, no fim de 1944, pôde publicar em primeira mão um dos poemas mais belos e importantes da literatura brasileira contemporânea: PROCURA DA POESIA.

De permeio, no dia 9 de novembro de1943, os estudantes de direito fizeram contra a ditadura da época uma passeata de protesto, que foi dissolvida a bala pela polícia, com morte de u rapaz, ferimento de vários outros e dezenas de prisões. Como a censura à imprensa e ao rádio era absoluta, resolvi mandar a amigos do Rio uma informação sobre os acontecimentos, a fim de desmascarar ao menos para algumas pessoas responsáveis as deformações previsíveis da versão oficial. Foi o que fiz com a ajuda de uma colega no fim daquela tarde, contando inclusive que o dia estava cinzento, frio, com vento e uma chuvinha ocasional. Tiramos várias cópias a máquina, em papel fino, e mandamos à gente com a qual estávamos ligados, remetendo também uma para Drummond. Pensando na coisa, vejo agora que nunca soube se o relato chegou aos destinatários; mas tempos depois recebi de Drummond a cópia de um poema novo, O MEDO, dedicado a mim e com epígrafe tirada de um artigo meu daquele ano - o que me encheu de um desvanecimento que se pode imaginar. Ora, lá aparecem uns versos que sempre supus alusivos ao relato dos acontecimentos daquela tarde de repressão violenta, embora nunca tenha me certificado a respeito com o autor:

Refugiamo-nos no amor,

Este célebre sentimento,

E o amor faltou: chovia,

Ventava, fazia frio em S. Paulo.

Fazia frio em S. Paulo...

Nevava. 
desse esgarçamento se faz notar não apenas “fora”, mas também "dentro” do texto, no “marco poético” que são "Carta a Stalingrado” e “Telegrama de Moscou”, na medida em que as figurações da Resistência passam a explicitar-se (“antes”, implicitam-se). A identidade paradoxal entre o lugar poético do eu, “a tamanha distância”"144 (enunciativa, mas não conotativa) do lugar poético do tu, assim como a alteridade (d)enunciada nos poemas “anteriores", encontra fundamento no contexto, a um tempo "poético" (a coletânea) e “prosaico” (a conjuntura), de A rosa do povo.

Em “Telegrama de Moscou”, tem-se a impressão de que o emissor posiciona-se em pleno território soviético, quando na verdade a figuração do poema, imaginativa ${ }^{145}$, antes explicita a “construção" duma nova identidade entre diferentes sujeitos do discurso, e não algo de antemão pronto, e isto se faz segundo uma escala empática e internacionalista, em que a "antiga cidade” e a "nova”, o “eu” e o "tu” amalgamam-se com vistas a refazerem-se. Finda a Batalha de Stalingrado, inicia-se a reconstrução da cidade $^{146}$.

Após os dois poemas que figuram marcos na superação poética do Nazifascismo $^{147}$, seguem-se “Mas viveremos”, “Visão 1944” e “Com o russo em Berlim”.

Naquele tempo Drummond difundia os seus poemas políticos impublicáveis por meio de cópias remetidas aos amigos; estes, por sua vez, as multiplicavam e elas corriam o país, datilografadas e mimeografadas. Assim se espalharam: DEPOIS QUE BARCELONA CAIR; CARTA A STALINGRADO; TELEGRAMA DE MOSCOU; COM O RUSSO EM BERLIM; MAS VIVEREMOS; VISÃO 1944 recolhidos mais tarde em Rosa do povo, menos o primeiro. Por este meio o chefe de gabinete exercia uma atividade constante e decidida, animando muita gente com o exemplo de uma participação tão alta, naquele momento que para muitos deveria levar ao "mundo novo" que um dos poemas queria ajudar a nascer." (Antonio CANDIDO, "Fazia frio em São Paulo", in Recortes.)

144 Verso 41 do poema "Carta a Stalingrado".

145 Nos primeiros versos, encontra-se a chave expressiva do poema, na medida em que o seu entendimento pressupõe a participação ativa do leitor, que colabora na "reconstrução" de cada sentença, sintaticamente incompleta ou elíptica, pontuando-a ou estabelecendo os elementos de ligação apropriados.

1. Pedra por pedra reconstruiremos a cidade.

2. $\quad$ Casa e mais casa se cobrirá o chão.

3. Rua e mais rua o trânsito ressurgirá.

146 Este poema é significativo dum processo que percorre todo o livro: a "reescritura", figurada como "trabalho cotidiano" em que o "nome", ou o ato de "nomear" (ou "renomear"), tem uma importância a um tempo "simbólica", porque ressignifica, e "concreta", porque se explicita como significante.

147 Estes marcos não são de natureza exclusivamente "extra-literária", uma vez que, conforme procuramos demonstrar, as menções ao Nazi-fascismo não são apenas "referências aos fatos", mas participam da fatura formal. No caso da "lírica de guerra", não se trata apenas de referenciar a vitória soviética sobre a invasão alemã, ou a tomada de partido, até certo ponto involuntária, do Estado Novo contra o Eixo. Mais do que isso, trata-se de incorporar ao discurso poético a complexidade de lugares subjetivos: o lugar do eu e o lugar do tu. Estes lugares, que agora se explicitam (participam do enunciado), em outros momentos fazem-se implícitos (participam da denúncia), de modo que são relevantes ao processo de figuração, não importa se em termos de "função referencial" ou "poética". Essas "funções lingüísticas", para que se identifiquem, requerem a desvinculação entre os aspectos textuais e os aspectos contextuais da obra, o que empobrece, não só os seus significados, mas a própria capacidade de significação. Não dão conta, por exemplo, de perceber e explicar o fenômeno drummondiano do "gauchismo", segundo o qual índices de despersonalização fazem-se, na verdade, marcas profundamente subjetivas, líricas. 
Todos os três são sínteses que sugerem, imageticamente, aspectos da luta contra o Nazifascismo em âmbito mundial, mas, na verdade, revelam a condição de testemunha, não do que se "viu", nem do que se "ouviu", mas do "silêncio" que se impôs violentamente e que se burlou por decodificarem-se cifras e entrelinhas, silêncio que, agora, sente-se esgarçar de modo inexorável; e o sentido literário desse esgarçamento é, de fato, a sinestésica produção de “imagens” poéticas (em fluxos de sabor cinematográfico, sugeridos por metonímia). No terceiro deles, a repetição marcial do refrão “com o russo em Berlim” expressa, com altivez, a confiança na superação da ameaça nazi-fascista, por conta da invasão soviética à capital alemã. Entre todas essas imagens, no entanto, o sentido é menos o de "ver”, e mais o de “espiar”. É, em suma, o domínio do Gauche ${ }^{148}$ : a mesma subjetividade cuja coesão é o lirismo e cuja coerência é a pluralidade.

Em síntese, nota-se, no “bloco do engajamento”, ecos duma percepção formal que corresponde cronologicamente ao sentido histórico da Batalha de Stalingrado: antes, há o avanço do Eixo; depois, o seu recuo. Nos três primeiros poemas do "bloco", a subjetividade expressa-se por cifras, e enuncia o silêncio, com referências alusivas ao Nazi-fascismo; nos três últimos, a subjetividade enuncia a superação do silêncio, de modo não mais cifrado; nos dois poemas centrais, figura-se a Batalha decisiva, nomeando-se o "trauma” e apontando a sua superação.

Há, entre os poemas do livro, um sentido, não lógico, nem linear, mas psicológico, metonímico, que, de certa maneira, corresponde a esses três momentos intercambiáveis da subjetividade gauche : cifra, nomeação e catarse.

Em “Notícias”, o poema se constrói a partir de imagens do insulamento subjetivo, já nos cinco primeiros versos.

\footnotetext{
148 Affonso Romano de SANT'ANNA (in Drummond: o gauche no tempo, p. 38-39) afirma: "Caracteriza o gauche o contínuo desajustamento entre a sua realidade e a realidade exterior. Há uma crise permanente entre o sujeito e o objeto que, ao invés de interagirem e se completarem, terminam por se opor conflituosamente. Para usar um sinônimo drummoniano, tal tipo é um excêntrico (Os Excêntricos); perde a noção das proporções e, colocando-se fora do ponto que lhe seria natural para manter-se em equilíbrio, termina comportando-se como um deslocado, como uma displaced person dentro do conjunto. Enfim, seja como um gauche, como um excêntrico ou uma displaced person, manifesta-se sempre o conflito básico entre sujeito e objeto, nessas palavras, revelado através do dado espacial."
} 
1. Entre mim e os mortos há o mar

2. e os telegramas.

3. Há anos que nenhum navio parte

4. nem chega. Mas sempre os telegramas

5. frios, duros, sem conforto.

A "praia”, ou a "cidade litorânea”, é o lugar em que a subjetividade lírica de $A$ rosa do povo se situa, e a partir do qual o Gauche emite a sua voz.

45. Sento-me no chão da capital do país às cinco horas da tarde $e^{149}$

O "Rio de Janeiro" não é apenas a "capital do país” e, com isso, o centro ditatorial do Estado Novo. Mais do que isso, é o lugar em que a “participação” poética na Resistência à invasão nazi-fascista se faz em toda a sua precariedade ${ }^{150}$, cuja enunciação, entretanto, termina por se revelar um antídoto contra a grandiloqüência.

68. Como pois interpretar

69. o que os heróis não contam?

70. Como vencer o oceano

71. se é livre a navegação

72. mas proibido fazer barcos?

73. Fazer muros, fazer versos,

74. cunhar moedas de chuva,

75. inspecionar os faróis

76. para evitar que se acendam,

77. e devolver os cadáveres

78. ao mar, se acaso protestam,

79. eu vi; já não quero ver.

Em "Rola mundo", entre figurações do absurdo inominável, que é o belicismo nazi-fascista, esses versos 68-79 sugerem, numa espécie de crônica, aspectos cotidianos do Estado Novo, rompendo por um momento com a imaginação predominantemente surrealista do poema, e figurando, aparentemente de maneira menos mediata, a

\footnotetext{
149 Verso de "A flor e a náusea".

150 Vagner CAMILO afirma (in Drummond: Da Rosa do Povo à Rosa das Trevas, p. 243): "Uma vez determinadas as raízes históricas e sociais da culpa, cumpre observar que ela só começa a despontar na lírica drummondiana a partir de 40, através das várias manifestações diretas e indiretas de que tratou Antonio Candido sob o rótulo de "inquietudes". Nem poderia ser de outro modo, pois é só nesse momento, com a transferência definitiva de Drummond para o Rio, o ingresso no funcionalismo público, as exigências de participação e posicionamento político-ideológico do artista e intelectual motivadas pela hora presente e a opção por uma poesia de inspiração social, que se pode dar o confronto aberto das posições contraditórias de que redunda a culpa em questão.”
} 
repressão, a censura e a ordem governamental para que os faróis se mantivessem apagados, com o intuito de preservar a costa brasileira de novos ataques, após o bombardeio de navios nacionais por submarinos alemães. ${ }^{151}$ (Evidentemente, a inserção dessa estrofe "realista” num poema predominantemente "super-realista” termina por subverter a figuração do “cotidiano”, que se faz impregnar do absurdo poético).
1. É noite. Sinto que é noite
2. não porque a sombra descesse
3. (bem me importa a face negra)
4. mas porque dentro de mim,
5. no fundo de mim, o grito
6. se calou, fez-se desânimo.
7. Sinto que nós somos noite,
8. que palpitamos no escuro
9. $\quad$ e em noite nos dissolvemos.
10. Sinto que é noite no vento,
11. noite nas águas, na pedra.
12. E que adianta uma lâmpada?
13. E que adianta uma voz?
14. É noite no meu amigo.
15. É noite no submarino. ${ }^{152}$

A imagem da “escuridão”, como aspecto cotidiano, mas que também termina por simbolizar a própria situação opressiva do avanço fascista dentro e fora do país (e, sobretudo, um "escuro" que se internaliza subjetivamente), encontra-se figurada ao longo de todo o livro.

\section{4. É tempo de meio silêncio, \\ 75. de boca gelada e murmúrio, \\ 76. palavra indireta, aviso}

\footnotetext{
151 "Com a entrada do Brasil na guerra, em breve começariam a ser adotados no Rio de Janeiro alguns procedimentos exigidos pela chamada 'defesa passiva'. À noite, as luzes eram apagadas nas áreas mais próximas da orla marítima, e as lâmpadas da rua pintadas de preto. Durante essas noites, com as portas e janelas da sua casa da rua Joaquim Nabuco fechadas uma a uma, para que não passasse nenhuma claridade para o lado de fora, Drummond instalava-se diante do rádio, acompanhando pela trasmissão o movimento dos exércitos na Europa e através deles alguma coisa do embate entre democracia e nazifascismo.

'À noite, ele ou estava ouvindo rádio, ou escrevendo', lembra um sobrinho do poeta, Heraldo Drummond de Andrade, que, então com 17 anos, passou boa parte do ano de 1942 na casa do tio no Rio de Janeiro. $\mathrm{Na}$ verdade, a maioria dos poemas desta época têm, além do sopro épico, um quê de cabograma noturno, de emissão radiofônica clandestina, de estímulo e palavra de ordem para combatentes. Assim, por exemplo, com poemas como Telegrama de Moscou, ou o arrebatado Carta a Stalingrado. Ou então o Mas viveremos, que na verdade chamava-se originariamente $A$ morte da III Internacional, e foi mandado para São Paulo, até chegas às mãos de Antonio Candido, que fez o poema circular clandestinamente nos meios antifascistas. Nesta versão do poema ainda havia um comovido 'E teu rosto, Lênin', depois apagado." (CANÇADO, Os sapatos de Orfeu, p. 177-178.)

152 Versos de "Passagem da noite".
} 
O medo, princípio do governo ditatorial, revela-se, na verdade, um ethos burguês, e faz com que o avanço fascista seja visto como conseqüência natural do próprio aburguesamento da sociedade.

1. $\quad$ Em verdade temos medo.

2. Nascemos escuro.

3. As existências são poucas:

4. Carteiro, ditador, soldado.

5. $\quad$ Nosso destino, incompleto.

27. Assim nos criam burgueses.

28. Nosso caminho: traçado.

29. Por que morrer em conjunto?

30. E se todos nós vivêssemos?

46. O medo, com sua física,

47. tanto produz: carcereiros,

48. edifícios, escritores,

49. este poema; outras vidas. ${ }^{154}$

De fato, os papéis sociais vêem-se restritos pelo ethos e pela práxis da sociedade burguesa, e essa restrição a aspectos importantes da personalidade é uma problemática temático-formal em diversos poemas de A rosa do povo ${ }^{155}$. A própria subjetividade gauche, que em momentos como este enuncia claramente a interdição, em muitos outros momentos termina por internalizá-la (por medo de prisão e tortura, ou então pelo próprio envolvimento com o mundo fragmentário). Veja-se, nesse sentido, "Nos áureos tempos”. Irônico desde o título, o poema subverte a idealização romântico-burguesa da infância, e, ao fazê-lo, denuncia, não apenas a escatologia da mítica e clássica "idade de ouro", mas, sobretudo, a "idade de ferro", que é o presente ${ }^{156}$, lugar a partir do qual

\footnotetext{
153 Versos de "Nosso tempo".

154 Versos de "O medo".

155 Agnes HELLER, O cotidiano e a história.

${ }^{156}$ Nos primeiros versos deste poema, a alusão irônica ao presente totalitário de perseguições e prisões faz-se evidente:

1. Nos áureos tempos

2. a rua era tanta.

3. O lado direito

4. retinha os jardins.

5. Neles penetrávamos

6. indo aparecer

7. já no esquerdo lado
} 
evocam-se as recordações e que, no final do poema, prevalece por sobre o passado, inclusive como escala a partir da qual aspectos pretéritos reconstroem-se, sob a forma da memória.
37. Chegando ao limite
38. dos tempos atuais,
39. eis-nos interditos
40. enquanto prosperam
41. os jardins da gripe,
42. os bondes do tédio,
43. as lojas do pranto.
44. O espaço é pequeno.
45. Aqui amontoados,
46. e de mão em mão
47. um papel circula
48. em branco e sigilo
49. talvez o prospecto
50. dos áureos tempos.

É possível perceber que o presente do eu, em meio a outras subjetividades, é, não apenas o avanço das relações sociais mercantilizadas e da modernização conservadora, mas, sobretudo, a "interdição" que veda a liberdade de comunicar-se, de constituir memória e de, com isso, construir uma identidade pessoal ${ }^{157}$. Ao passo que se alude à censura e à prisão, faz-se questão de enunciar a própria burla da conjuntura ditatorial, numa auto-referência do texto ao seu próprio contexto de produção e circulação imediato $^{158}$, visto que muitos dos poemas de $A$ rosa do povo, bem como outros textos literários, circularam clandestinamente durante a ditadura de Vargas.

8. que em ferros jazia.

157 Esta experiência do mundo, figurada em termos de trauma e despersonalização, figura-se também em "Anoitecer", com a expressividade anafórica do refrão ("desta hora tenho medo") a provocar o eco opressivo das rimas toantes em /edo/. Vejam-se os versos finais:

22. Hora de delicadeza,

23. gasalho, sombra, silêncio.

24. Haverá disso no mundo?

25. É antes a hora dos corvos,

26. bicando em mim, meu passado,

27. meu futuro, meu degredo;

28. desta hora, sim, tenho medo.

158 O filme Memórias do cárcere, dirigido por Nelson Pereira dos Santos, muito embora se paute, na maior parte do tempo, por imagens e termos sugeridos pela própria obra de Graciliano Ramos, entretanto toma a liberdade, em alguns momentos, de inserir figurações originais, sempre com uma compreensão muito aguda e um respeito muito reverente pela expressividade do livro. Tais são os casos em que, durante o traslado, no porão do Manaus, para o Rio de Janeiro, os prisioneiros, embriagados, entoam "O canto da Ema”, de Jackson do Pandeiro (no livro, trata-se de um samba), ou então quando, já na Colônia Correcional, as mulheres cantam "O orvalho vem caindo", de Noel Rosa - momentos cinematograficamente sublimes. Entre esses momentos, está a transferência do impecável personagem Graciliano Ramos do presídio em Ilha Grande, de 
Afora isso, a “física do medo", parodiada na (des)construção literária do “Edifício São Borja” (alegoria do Brasil autoritário), revela, em um só golpe, a farsa da “revolução burguesa” de Vargas, e a farsa da personificação do seu projeto político no culto ao Chefe, tão próprio aos regimes de inspiração nazi-fascista ${ }^{159}$.

9. $\quad$ Ritmo de poeta mais forte

10. nesta mão se inoculando

11. projeto de fuga ao Chile

12. à tua casa de infância

13. ao adro da igreja tombada

14. São Borja

Nesse poema, é evidente a agressão, não apenas ao projeto de modernização varguista, cujo símbolo arquitetônico-urbanístico foi o crescimento vertical das grandes metrópoles, mas à própria figura do Ditador, que nasceu na região de Sete Povos das Missões, na cidade de São Borja, e que foi objeto do culto promovido pelo Departamento de Imprensa e Propaganda. A importância simbólica de desmistificá-lo é de uma agressividade tal que não se justifica incluir o poema entre aqueles em que não há “função referencial”, mas “fechamento do discurso sobre si próprio”160, a não ser que se recuse identificar, no texto propriamente dito, elementos que, entretanto, referenciam explicitamente o seu contexto de produção (caso em que o poema, além de hermético, torna-se desprovido de significado).

60. Canoa sem fado e peixes

61. canções jandaias madréporas

62. anêmonas

63. sorrimos

64. São Borja

65. outra vez sorrimos

Nestes outros versos do mesmo "Edifício São Borja”, não será improcedente identificar uma alusão figurativa à tortura. Os elementos de paródia ao nacionalismo

volta para a Colônia Correcional. O Diretor do presídio, ameaçado pelo Autor, decide buscar e apreender as suas anotações, realizadas durante o período do seu encarceramento. Os presos, cúmplices do escritor, imediatamente recolhem as folhas e, em fila, passam-nas sorrateiramente de mão em mão, cada qual ocultando, por sob as suas roupas, algumas delas. Esta cena, além de cinematograficamente muito bela, tem um poder de síntese incrível, e, de certa maneira, revela uma imagem que no poema "Nos áureos tempos" de A rosa do povo, ou em outros poemas da coletânea, e ainda em outras obras literárias do (ou sobre o) período, são muito significativas, não apenas em termos "referenciais", mas também "poéticos".

159 Cf. "Cultura e poder político", in OLIVEIRA et alli, op. cit., p. 71-108.

${ }^{160}$ Iumna SIMON, op. cit. 
varguista deixam entrever, entre metáforas ligadas ao campo semântico de "água”, uma das formas do polissêmico termo “áporo”, que são as "madréporas” (invertebrados marinhos que compõem o coral), além de "anêmonas”, numa evidente sugestão de imersão "labiríntica”, “sem-saída”, nas águas do mar. Depois de figurar a "canoa sem fado e peixes”, a justaposição de “canções jandaias madréporas / anêmonas” sugere a imersão brusca, imposta, logo seguida pelos (no contexto) grotescos v. 63 e 65 “sorrimos” e “outra vez sorrimos”, entremeados pelo v. 64 “São Borja”, expressão que se revela, de fato, uma alusão paródica às práticas ditatoriais do governo Vargas.

66. O tempo se despencando

67. por trás das guerras púnicas

68. na face dos gregos

69. num dedo de estátua

70. posse de anel

71. segredo

72. São Borja

73. A vida povoada

74. a morte sem aproveitadores

75. a eternidade afinal expelida

76. estamos todos presentes

77. felizes calados

78. completos

79. Santo São Borja.

O sarcasmo com elementos da estética clássica pode-se perceber neste e em diversos outros poemas da coletânea, inclusive nos sonetilhos "Áporo" e "O poeta escolhe seu túmulo", bem como em "O mito", o que, de fato, configura um ataque a elementos da própria estética filo-fascista. De resto, o "silêncio", que é um tema onipresente em A rosa do povo, assim como o “mar” e o campo semântico que instaura, muitas vezes serve como alusão direta às práticas de censura, tortura e repressão, impostas pelos regimes ditatoriais, não raro figuradas através da sua introjeção pela subjetividade lírica.

No poema "Nova canção do exílio”, o sarcasmo com o nacionalismo reaparece, desta vez em torno do "desterro" (outro tema constante em todo o livro e que faz referência evidente à conjuntura ditatorial).

1. Um sabiá

2. na palmeira, longe. 
3. Estas aves cantam

4. um outro canto.

5. O céu cintila

6. sobre flores úmidas.

7. Vozes na mata,

8. e o amor maior.

9. Só, na noite,

10. seria feliz:

11. um sabiá,

12. na palmeira, longe.

13. Onde é tudo belo

14. e fantástico,

15. só, na noite,

16. seria feliz.

17. (Um sabiá,

18. na palmeira, longe.)

19. Ainda um grito de vida e

20. voltar

21. para onde é tudo belo

22. e fantástico:

23. a palmeira, o sabiá,

24. o longe.

O $19^{\circ}$ verso do poema ilumina todos os demais, em que se insinua uma subjetividade fortemente atuante, mas sob um efeito paradoxal de alheamento. O dêitico “estas” ( $3^{\circ}$ verso) já não deixa dúvidas quanto à escala lírica do Gauche, cuja subjetividade parece sugerir-se elíptica mas, com um pouco mais de atenção, revela-se em toda a sua angústia. “Ainda um grito de vida” é a denúncia da tortura em curso - no aqui e no agora da leitura -, e que torna necessário o recurso à fantasia psíquica do exílio como uma fuga desesperada e imaginária do presente insuportável, de que são índices o amortecimento da sensibilidade e a despersonalização sugerida. De fato, a troca, na última estrofe, dos artigos indefinidos por artigos definidos, para a caracterização dos reiterados “palmeira” e "sabiá”161 (emblemas de nacionalidade em construção desde o indianismo romântico) como algo incrivelmente distante, acaba revelando o distanciamento absurdo do eu em relação a si próprio e ao seu próprio espaço-tempo, numa espécie de exílio do exílio: denúncia magistral do nacionalismo totalitário, que se percebe infiltrado na própria subjetividade lírica.

161 No contexto da ditadura militar, entre 1964-1985, a canção "Sabiá", composta por Chico Buarque e Tom Jobim, de certa forma, retoma essa tradição literária. 
O “exílio do exílio” é uma maneira paradoxal, mas não menos importante, de engajamento, e também se enuncia nos primeiros versos de “Vida menor”.

\author{
1. A fuga do real, \\ 2. ainda mais longe a fuga do feérico, \\ 3. mais longe de tudo, a fuga de si mesmo, \\ 4. a fuga da fuga, o exílio \\ 5. sem água e palavra, a perda \\ 6. voluntária de amor e memória, \\ 7. o eco \\ 8. já não correspondendo ao apelo, e este fundindo-se, \\ 9. a mão tornando-se enorme e desaparecendo \\ 10. desfigurada, todos os gestos afinal impossíveis, \\ 11. senão inúteis, \\ 12. a desnecessidade do canto, a limpeza \\ 13. da cor, nem braço a mover-se nem unha crescendo. \\ 14. Não a morte, contudo.
}

Expressando a dor de uma maneira que escapa ao sentimental, mas que não recusa a subjetividade (porque, ao contrário, advém de uma percepção íntima tão traumática que mal se pode enunciar), o Gauche não foge ao engajamento, ainda que se mostre tão subjetivamente envolvido com o mundo que esse envolvimento se enuncia, paradoxalmente, insustentável. A dor extrema, quase inefável, mas nem por isso eludida (apesar do desejo enunciado da sua recusa), é o contrário de “intransitividade”: é o envolvimento paroxístico, a ponto de figurar-se inviável (note-se, entretanto, que o ato figurativo já é a contradição do seu próprio enunciado ${ }^{162}$ ). A “fuga da fuga” já não é

\footnotetext{
162 “A leitura de 'amar-amaro' e 'Nudez’ ofereceu-nos material para reflexões que pretendem, agora, maior generalidade. Há, nos dois poemas, uma postura amadurecida da consciência frente ao objeto problemático. A particularidade de cada um está na modulação de um tônus típico: o do desengano, o da recusa. Em 'amaramaro' a expressão participa da impossibilidade do objeto (sentimento amoroso, consolo); em 'Nudez' o objeto (a poesia, o próprio canto) participa da impossibilidade de expressão (quer ser a inexpressão). Ambos anulam o real e a sua representação; têm, como força objetiva, a forma de que a poesia necessita para agir com o poder de negar(-se). E, como ao ser presença, toda forma á alguma afirmação, a recusa radical (subjetividade profunda) se questiona pela mediação compulsória da linguagem, ponte para o mundo social. Gramaticalmente, essa ponte é muitas vezes representada pela interrogação. Semanticamente, lato sensu, pela novidade que é cada poema, em seu frescor original. O novo, ao afastar a convenção, não pode estar contido no repertório negativo da humanidade, ainda que se tenha de colocar como um não. As imagens que surgem aos nossos olhos o fazem pela primeira vez - e o sentido do desgaste que querem acusar tem para nós, em primeiro lugar, o sentido de uma descoberta. O poeta é, neste caso, aparentemente, um ser traído: provoca prazer ao projetar o sofrimento; ilumina fecundamente através de imagens sombrias. É um ser traído aparentemente: ele mesmo terá buscado, em última instância, essa área de luz: luz da expressão comum, que solidariza a condição desenganada e abre, para depois dela, um espaço novo onde todos nos somamos, graças à referência de um novo ser: o poema. Adorno insiste nessa condição da lírica moderna: a de que o impulso criador (superficialmente visto como motivo individual) participa de um genuíno projeto social, na medida em que a imersão do eu em si mesmo é a recusa da ideologia (má consciência): ideologia que mascara em interesses gerais os interesses de poucos." (Alcides VILLAÇA, Consciência lírica em Drummond, p. 54-55, grifos do autor).
} 
mais a "fuga”, mas o seu inverso: é “participação”, no que isso implica de mais trágico. Ademais, a denúncia especulativa do “exílio”, expressa como “exílio do exílio”, revelase uma estratégia “poética”, e, por isso mesmo, eficaz, de engajamento.

O “desterro", como enunciado e / ou como denúncia em A rosa do povo, não pode ser pensado como um “assunto” entre outros, desprovido de vínculos, a não ser por recortes que desconsiderem o contexto literário (a coletânea) e o contexto extra-literário (o Estado Novo, a Segunda Guerra Mundial, a Resistência), definitivamente essenciais para a compreensão do fundamento lírico da coletânea (as “inquietudes”) e dos significados do “engajamento” literário. "Vida menor”, visto como um fragmento, parece sugerir que se pense num Drummond "metafísico"163 "schopenhaueriano”164 etc.; mas, quando devidamente contextualizado, as suas imagens e os seus recursos passam a revelar camadas de significados mais "poéticos” (lingüisticamente complexos), e menos “filosóficos” (tematicamente imediatos).

95. Depois de tantas visões

96. já não vale concluir

97. se o melhor é deitar fora

98. a um tempo os olhos e os óculos.

99. E se a vontade de ver

100. também cabe ser extinta,

101. se as visões, interceptadas,

102. e tudo mais abolido.

Esse trecho do poema "Rola mundo", imediatamente anterior ao chamado “bloco do fechamento”, já enuncia o quão inomináveis são os eventos contemporâneos, e nisso está a chave para a compreensão dos mais diversos recursos expressivos,

\footnotetext{
163 Afonso Romano de SANT'ANNA afirma que: "No substrato do pensamento poético-metafísico de Drummond, podem-se assinalar alguns traços de um pensamento existencialista, sem que com isto se diga que o poeta pertença a esta ou àquela corrente filosófica. No entanto, se, por um lado, é possível indicar influência de uma filosofia de época em seus versos, pode-se dizer também que o existencialismo é um acercamento poético às fontes do Ser. E nessa obra a linguagem seria o instrumento pelo qual o Ser desvelaria sua consciência, abrindo-se para a realidade interior e exterior.” (op. cit., p. 32)

164 Merquior, ao apreciar o que denomina "a segunda fase do estilo lírico de Drummond: o meio-dia da escrita", assinala que são três as conquistas dessa "fase": o realismo social, o metalirismo e o lirismo de interrogação filosófica. Especificamente sobre a "poesia filosófica" de $A$ rosa do povo, afirma: "Estranha vida além do tempo, aquém do destino biológico (nenhum gasto de tecidos; a ausência deles)! Pensamos no 'desligamento' ideal de Schopenhauer, no hedonismo ascético da vida contemplativa, pois a felicidade da 'vida menor' é antes de tudo ausência de dor, é a vida 'já sem dor', 'o que se possa desejar de menos cruel...' Entretanto não se trata, como em Schopenhauer, de escapar à 'selva selvaggia' da existência atormentada pelos apetites, em direção ao ser. A 'vida que aspiramos com paz no cansaço' de Drummond não troca as quimeras do desejo por uma Verdade metafísica: (...) Não obstante, com a devida ressalva, somos tentados a considerar a 'inteligência do universo' de Drummond o segundo caso de schopenhauerismo das letras brasileiras, sendo o primeiro, naturalmente, Machado de Assis, uma das leituras favoritas de Drummond." (José Guilherme MERQUIOR, Verso universo em Drummond, p. 97-98).
} 
aparentemente herméticos, mas que se vinculam a fenômenos diante dos quais a subjetividade lírica constata toda a sua precariedade - para que o engajamento autoral se cumpra. ${ }^{165}$

10. Visito os fatos, não te encontro.

11. Onde te ocultas, precária síntese,

12. penhor de meu sono, luz

13. dormindo acesa na varanda?

14. Miúdas certezas de empréstimo, nenhum beijo

15. sobe ao ombro para contar-me

16. a cidade dos homens completos.

17. Calo-me, espero, decifro.

18. As coisas talvez melhorem.

19. São tão fortes as coisas!

20. Mas eu não sou as coisas e me revolto.

21. Tenho palavras em mim buscando canal,

22. são roucas e duras,

23. irritadas, enérgicas,

24. comprimidas há tanto tempo,

25. perderam o sentido, apenas querem explodir. ${ }^{166}$

A impossibilidade de "contar”, isto é, de conferir sentido à experiência vivida por meios narrativos, mais do que uma estratégia retórica, é uma estratégia poética. Em vez de conferir explicações conceituais e discursivas para fenômenos que implicam (mas transcendem) a escala do vivido, o pensamento lingüístico drummondiano mimetiza aspectos aparentemente desconexos desses fenômenos, para, assim, apreendêlos - e transfigurá-los ${ }^{167}$. Em "Nosso tempo", por exemplo, em que pese o enunciado da precariedade do eu diante do mundo, há uma compreensão estética aguda do (sem-) sentido tecnocrático do cotidiano industrial, em toda a sua (ir)racionalidade.

65. Ó conta, velha preta, ó jornalista, poeta, pequeno historiador urbano, 66. ó surdo-mudo, depositário de meus desfalecimentos, abre-te e conta, 67. moça presa, na memória, velho aleijado, baratas dos arquivos, portas

68. pessoas e coisas enigmáticas, contai,

[rangentes, solidão e asco,

\footnotetext{
165 De fato, convém diferenciar subjetividade lírica de autoria, porque, por maiores índices de referências autobiográficas que existam, o recurso do gauchismo vem a impedir o mero confessionalismo e, com isso, garante potência à expressão poética.

166 Versos de "Nosso tempo".

${ }^{167}$ A subjetividade lírica do Gauche enuncia a precariedade e o silêncio para que a subjetividade do autor e a do público superem a interdição.
} 
69. capa de poeira dos pianos desmantelados, contai;

70. velhos selos do imperador, aparelhos de porcelana partidos, contai;

71. ossos na rua, fragmentos de jornal, colchetes no chão da costureira, luto

[no braço, pombas cães errantes, animais caçados, contai.

72. Tudo tão difícil depois que vos calastes...

73. E muitos de vós nunca se abriram.

A subjetividade precária (insular) diante do mundo não é apenas a do eu-lírico: a intersubjetividade também se revela interdita no mundo totalitário (entendendo-se como faces de um mesmo fenômeno tanto o "mundo capitalista”, que o "poeta” de "Nosso tempo" “promete ajudar a destruir" ${ }^{168}$, como o belicismo nazi-fascista, de que o mesmo Gauche escarnece).

35. Símbolos obscuros se multiplicam.

36. Guerra, verdade, flores?

37. Dos laboratórios platônicos mobilizados

38. vem um sopro que cresta as faces

39. e dissipa, na praia, as palavras.

A produção do (sem-)sentido capitalista, enunciada nesta imagem “despetrarquizante”169, desfigura-se no próprio sentido formal deste e de outros poemas, marcados pela mimese da "mutilação” (cujo índice mais expressivo são os freqüentes enjambements ${ }^{170}$ ), que, entretanto, não é o sentido poético último, senão uma denúncia, que, invariavelmente, faz-se transfigurar. Nesses termos, a estética de A rosa do povo figura, como cifras de um real (já por si codificado, e que contamina as relações subjetivas), os elementos de uma percepção artística penetrante, que, no final das contas, revela uma intelecção aguda do vivido.

A cifra, além de conferir sentido a diversos recursos formais, aparentemente desconexos em sua pluralidade vertiginosa, mas que encontra coesão na subjetividade gauche, configura também uma escala perceptiva. Em “Rola mundo”, as “visões” do inominável (por isso mesmo, expressas em termos do absurdo) levam à figuração da própria subjetividade em um grau de despersonalização tal que, de tão expressiva, torna a repetir-se em outros momentos importantes da coletânea.

\footnotetext{
168 Referência aos v. 175-182 do poema "Nosso tempo".

169 Para Merquior, a poesia drummondiana em diversos momentos se opõe à idealização de fundo platônico, representado, por exemplo, pela poesia de Petrarca. (op. cit., p. 32 e 88.)

${ }^{170}$ José Guilherme MERQUIOR (op. cit., p. 31) refere-se a "esta arte tipicamente drummondiana que é o enjambement."
} 
90. E vi minha vida toda

91. contrair-se num inseto.

92. Seu complicado instrumento

93. de vôo e de hibernação,

94. sua cólera zumbidora,

95. seu frágil bater de élitros,

96. seu brilho de pôr de tarde

97. e suas imundas patas...

98. Joguei tudo no bueiro.

99. Fragmentos de borracha

100. e

101. cheiro de rolha queimada:

102. eis quanto me liga ao mundo.

103. Outras riquezas ocultas,

104. adeus, se despedaçaram.

O grotesco kafkiano da subjetividade-inseto diante do "processo" ininteligível repete-se no poema seguinte, “Áporo”, e também em outro poema do "bloco do fechamento": "Economia dos mares terrestres".

1. A queixa

2. comprimida na garrafa

3. quer escapar

4. reunir os povos

5. dizer a Matilde que lhe perdoa

6. organizar a vida dos índios,

7. a queixa

8. no vácuo

9. lembra uma queixa menor.

(...)

16. Limita-se

17. à contemplação metódica da mosca

18. fora da garrafa

19. (mas já são outros problemas).

Neste penúltimo poema do "bloco do fechamento”, há um distanciamento crítico acentuado entre o eu-lírico e a enunciação da sua subjetividade, que se efetua sobretudo pelo tom irônico (mas nota-se, por sob o chiste, a subjetividade dilacerada diante da interdição objetiva). Em "Rola mundo" (o poema que antecede o "bloco") e em “Áporo” (o primeiro poema do “bloco”), também se nota o distanciamento, uma vez que os três poemas expressam graus de despersonalização. Mas em "Economia dos mares terrestres”, o “inseto” não mais personifica o próprio eu, e sim o seu desejo, por 
si só impotente, de romper com a interdição (interdição que é, a um tempo, a sua própria condição objetiva).

O animal abjeto, de "patas imundas”, marca o lugar interdito do eu-lírico e, mais que isso, a sua condição nem um pouco heróica. Objeto visual, o "inseto" (ou melhor, os seus "membros inferiores": as "imundas patas") sugere o próprio ato de "cavar" como transfiguração possível da situação “aporética”. A “flor antieuclidana” que, “sozinha”171, "ilude a polícia, rompe o asfalto”"172, longe de ser apenas uma alegoria fácil da "revolução”, é, mais que isso, algo em si “infenso à efusão lírica”173. Essa "flor”, que se "anuncia”"174 de um modo tão complexo e "significativo”, previne-se, reflexiva, contra quaisquer facilidades retóricas. Ela própria, consciente de que "O tempo é ainda de fezes, maus poemas, alucinações e espera” ${ }^{\text {"175 }}$, não perde a escala do “rés-do-chão"176 quando, reflexiva, "forma-se" "177. A sua contra-face "inseto" é o seu antídoto contra possíveis dimensões “sublimes” de uma “flor” idealizada, “petrarcalizada”, “que a terra [não] há de comer”178.

A dimensão identitária entre eu e mundo, entre a subjetividade lírica e outras subjetividades, jamais cria descompassos entre a escala lírica e a dimensão do engajamento, conforme se percebe na análise interpretativa de "Consideração do poema” ou de "Procura da poesia”. Nesse sentido, é bastante significativa a figura da “escavação”, ela também presente em muitos outros poemas, além de em “Áporo”, "Rola mundo” e “A flor e a náusea”.

A imagem da "flor", que nasce da decomposição de materiais orgânicos (as “fezes” de “A flor e a náusea”, por exemplo, v. 8), e que, com ser vida, não nega, antes pressupõe, a morte, compõe uma visão de mundo, em A rosa do povo, visceralmente atrelada ao desejo do orgânico, como recusa do mecânico. Nela, invariavelmente se

\footnotetext{
${ }^{171}$ Expressões que remetem ao poema "Áporo", v. 12-14.

172 "A flor e a náusea", v. 38.

173 "Procura da poesia", v. 7.

174 Menção ao poema "Anúncio da rosa".

175 "A flor e a náusea”, v. 8.

176 Cf. "Consideração do poema":

45. Ele é tão baixo que sequer o escuta

46. ouvido rente ao chão. Mas é tão alto

47. que as pedras o absorvem. Está na mesa

48. aberta em livros, cartas e remédios.

49. Na parede infiltrou-se. O bonde, a rua,

50. o uniforme do colégio se transformam,

51. são ondas de carinho te envolvendo.

177 “Áporo”, v. 14.

${ }^{178}$ Cf. "Os últimos dias":

1. Que a terra há de comer.
} 
burla qualquer tentativa de figurar um "sublime”, que implique a perda de vínculos com “o finito e a matéria”179. O recurso ao grotesco é um dos elementos, senão o principal, que configuram essa cosmovisão, funcionando como uma espécie de escala. Nesse sentido, as imagens da morte são fundamentais, e comportam figurações alusivas das práticas totalitárias, mas também comportam outros aspectos da existência, não se estabelecendo entre elas nenhuma importância em termos de hierarquia, sendo, ao contrário, concorrentes, e não divergentes.

37. Nas camadas marítimas, os peixes

38. me devorando; e a carga se perdendo,

39. a carga mais preciosa: para entrar

$40 . \quad$ com o russo em Berlim.

Esses versos, como aliás todo o poema em que se inserem (“Com o russo em Berlim”), nomeiam referências conjunturais que, em outros poemas, vêm cifradas; vejase, a respeito, o poema "Equívoco":

1. Na noite sem lua perdi o chapéu.

2. O chapéu era branco e deles passarinhos

3. saíam para a glória, transportando-me ao céu.

4. A neblina gelou-me até os nervos e as tias.

5. Fiquei na praça oval aguardando a galera

6. com fiscais que me perdoassem e me abrissem os rios.

7. Um jardim sempre meu, de funcho e de coral,

8. ergueu-se pouco a pouco, e eram flores de velho,

9. murchando sem abrir, indecisas no mal.

10. Ressurgi para a escola, e de novo adquiri

11. a ciência de deslizar, tão própria de meus netos:

12. Sou apenas um peixe, mas que fuma e que ri,

13. e que ri e detesta.

Em "Equívoco", o sarcasmo e as figurações do absurdo pouco disfarçam o engajamento em questões conjunturais (as prisões arbitrárias por "crime de opinião" durante o Estado Novo, que não raro implicaram execuções sumárias, com corpos sendo

${ }^{179}$ Referência a "Consideração do poema”, v. 31 ("poeta do finito e da matéria”). 
lançados ao $\operatorname{mar}^{180}$ ); mais uma vez, figura-se o grotesco das "flores” em situação de “aporia”.

Em “Mas viveremos”, o tema da “aporia” já não é mais cifra, mas evidência:

33. Pois às vezes nem isso. Nada tínhamos

34 a não ser estas chagas pelas pernas,

35. este frio, esta ilha, este presídio,

36. este insulto, este cuspo, esta confiança.

"Esta ilha, este presídio” bem poderia ser uma referência a Ilha Grande, em que diversos intelectuais viram-se encarcerados durante o governo Vargas. Mas “ilha”, mais que uma alusão a eventos objetivos, é uma imagem literária do isolamento, um estado subjetivo, em A rosa do povo, com o qual o eu lírico busca romper .

59. É talvez um erro amarmos assim nossos parentes.

60. A identidade do sangue age como cadeia,

61. fora melhor rompê-la. Procurar meus parentes na Ásia,

62. onde o pão seja outro e não haja bens de família a preservar.

63. Por que ficar neste município, neste sobrenome?

64. Taras, doenças, dívidas; mal se respira no sótão.

65. Quisera abrir um buraco, varar o túnel, largar minha terra,

66. passando por baixo de seus problemas e lavouras, da eterna agência do correio, [e inaugurar novos antepassados em uma nova cidade.

O estado subjetivo de aporia em que o eu lírico se encontra é devido à memória opressiva da Família, cujo emblema supremo é o Pai, amado / odiado. Esse poema trata da procura do Gauche por compreender afetivamente o Pai morto, "exumando-o" simbolicamente.

1. Teu aniversário, no escuro,

2. não se comemora.

3. Escusa de levar-te esta gravata.

4. Já não tens roupa, nem precisas.

5. Numa toalha no espaço há o jantar,

6. mas teu jantar é silêncio, tua fome não come.

\footnotetext{
180 Vejam-se, também, estes versos de "Visão 1944":

43. Meus olhos são pequenos para ver

44. o deslizar do peixe sob as minas,

45. e sua convivência silenciosa

46. com os que afundam, corpos repartidos.
} 
O Gauche procura desesperadamente um contato com o Pai morto, num tom agressivo, eivado de mágoas, mas que só a muito custo consegue conter o afeto (amor / ódio) latente e o desejo do encontro (que se faz desafio). O contato com os objetos do Pai permite evocar a sua memória, esmiuçando-a em detalhes tão obsessivamente que as dobras do passado redivivo, uma vez desfeitas, talvez permitam compreender afetos e comportamentos tácitos de outrora, que, traumaticamente, restaram interditos (mas candentes, tanto que é imperativo revivê-los, ainda que através do confronto e da agressão).

O contato com a "gravata”, com o "último retrato” (v. 12), com o próprio local do sepultamento:

15. Tua imobilidade é perfeita. Embora a chuva,

16. o desconforto deste chão. Mas sempre amaste

17. o duro, o relento, a falta. O frio sente-se

18. em mim, que te visito. Em ti, a calma.

, com os "papéis do cofre” (v. 26-27), com as “casas que habitaste” (v. 27), com os "baús atulhados” (repleto de memórias “da monarquia, da escravidão, da tirania familiar”: v. 46-47) - nada disso parece revelar o “segredo” do Pai (v. 25, 58, 74, 82), a despeito de toda a procura - mais do que empática: sinestésica.

66. Quisera abandonar-te, negar-te, fugir-te,

67. mas curioso:

68. já não estás, e te sinto,

69. não me falas, e te converso.

70. E tanto nos entendemos, no escuro,

71. no pó, no sono.

Uma tão “longa conversa” (v. 85) com nenhuma resposta tece, no entanto, um retrato tão vivo do "Coronel” (v. 39-43) que todos os seus gestos resultam paradoxalmente muito mais eloqüentes que o seu silêncio.

87. Guardavas talvez o amor

88. em tripla cerca de espinhos.

A persona todo-poderosa do Proprietário, do Patriarca, produzida e reproduzida pela violência, mas destronada pela morte e pela exumação simbólica, apenas nestes 
termos pode revelar o seu núcleo de afeto e "humanidade": baixada e rebaixada ao “escuro”, putrefata (reduzida a “pó”: v. 73, ou a "húmus”, isto é: humilhada).

89. Já não precisas guardá-lo [o amor].

90. No escuro em que fazes anos,

91. no escuro,

92. é permitido sorrir.

Em “Como um presente”, a ironia, muito embora eivada de sofrimento empático, desde o título, passa a estabelecer relações de similitude entre o passado e o presente, entre o afeto e a agressão, subvertendo distâncias hierárquicas e assimetrias. Essas relações de similitude constroem, a um tempo, identidade e alteridade, como numa imagem especular. Trata-se, sem dúvida, de uma exumação simbólica do Pai ${ }^{181}$, amado mas odiado, uma das fontes do insulamento subjetivo do Gauche. A procura tortuosa do Gauche vem de saber-se Andrade, mas também de saber-se um Outro, “excêntrico"182. O enfrentamento das suas "raízes” é, também, o seu “aprofundamento”, fruto de um desejo ambíguo de encontro e superação. É um “exilarse do exílio" (na imagem do poema "Vida menor”), ou a superação simbólica do “desterro na própria terra” (na expressão tão aguda de outra obra, contemporânea ${ }^{183}$ ).

\footnotetext{
181 O poema "Rua da madrugada", imediatamente posterior a "Como um presente", é ainda mais explícito em sua imagética:

1. A chuva pingando

2. desenterrou mеи pai.

3. Nunca o imaginara

4. assim sepultado

5. ao peso dos bondes

6. em rua de asfalto,

7. palmeiras gigantes baloucando na praia

8. $\quad$ e uma voz de sono

9. a alisar-me o cabelo

10. de onde escorrem músicas,

11. dinheiro perdido,

12. confissões exaustas,

13. fichas, copos, pérolas.

A imagem, muito "cigana" (e, nesse sentido, baudelaireana: veja-se "Bohemian on voyage"), da "Roda da Fortuna", figurada pela roleta no cassino, retoma de maneira ainda mais evidente a exumação do Patriarca, tão avaro em afeto e bens materiais, e a afronta à castidade de sua memória.

182 Menção ao conceito proposto por Sant'Anna e que remete à problemática do gauchismo (cf. a nota 147 do presente capítulo).

183 “A tentativa de implantação da cultura européia em extenso território, dotado de condições naturais, se não adversas, largamente estranhas à sua tradição milenar, é, nas origens da sociedade brasileira, o fato dominante e mais rico em conseqüências. Trazendo de países distantes nossas formas de convívio, nossas instituições, nossas idéias, e timbrando em manter tudo isso em ambiente muitas vezes desfavorável e hostil, somos ainda hoje uns desterrados em nossa terra. Podemos construir obras excelentes, enriquecer nossa humanidade de aspectos novos e imprevistos, elevar à perfeição o tipo de civilização que representamos: o certo é que todo fruto de nosso trabalho ou de nossa preguiça parece participar de um sistema de evolução próprio de outro clima e de outra paisagem.
} 
Não se trata, nunca, de conformar-se à interdição, seja a do Patriarca, seja a do Chefe, mas de mimetizá-la, ainda que sob a escala de um "inseto", ou "verme” (v. 181 de “Nosso tempo”), “escavando-a”, invariavelmente com vistas à transfiguração.

A alteridade em A rosa do povo, ainda que não pressuponha o “desenraizamento” (porque, ao contrário, resulta de “escavar-se” a identidade), passa do desejo de "Como um presente":

60. ... Procurar meus parentes na Ásia

61. onde o pão seja outro e não haja bens de família a preservar.

a diversos momentos imagéticos, e, nesses termos, o poema "América” é muito significativo:

29. Uma rua começa em Itabira, que vai dar no meu coração.

30. Nessa rua passam meus pais, meus tios, a preta que me criou.

31. Passa também uma escola - o mapa -, o mundo de todas as cores.

32. Sei que há países roxos, ilhas brancas, promontórios azuis.

33. A terra é mais colorida do que redonda, os nomes gravam-se

34. em amarelo, em vermelho, em preto, no fundo cinza da infância.

35. América, muitas vezes viajei nas tuas tintas.

36. Sempre me perdia, não era fácil voltar.

37. O navio estava na sala.

38. Como rodava!

39. As cores foram murchando, ficou apenas o tom escuro, no mundo escuro.

40. Uma rua começa em Itabira, que vai dar em qualquer ponto da terra.

41. Nessa rua passam chineses, índios, negros, mexicanos, turcos, uruguaios.

42. Seus passos urgentes ressoam na pedra,

43. ressoam em mim.

44. Pisado por todos, como sorrir, pedir que sejam felizes?

45. Sou apenas uma rua

46. na cidadezinha de Minas,

47. humilde caminho da América.

48. $\quad$ Ainda bem que a noite baixou: é mais simples conversar à noite.

A escala lírica, mais uma vez, amplia o lugar do eu, entretanto recusando-se terminantemente ao sublime, à grandiloqüência e ao escapismo (escapismo paradoxal,

Assim, antes de perguntar até que ponto poderá alcançar bom êxito a tentativa, caberia averiguar até onde temos podido representar aquelas formas de convívio, instituições e idéias de que somos herdeiros." (Sérgio BUARQUE DE HOLANDA, Raízes do Brasil, p. 31.) 
quando pela via do panfleto). O "País dos Andrades"184, que é também a "cidadezinha de Minas”, permite que as mais vertiginosamente variadas dimensões do Gauche, aparentemente desconexas, encontrem na subjetividade lírica um fator de coesão, o que leva à contaminação recíproca entre a intimidade afetiva e o referencial objetivo (cujo trânsito é essencial para a construção da personalidade). O internacionalismo do Gauche, além de uma recusa marcada do nacionalismo burguês ou fascista (repita-se que esses termos, em A rosa do povo, equivalem-se), não implica o “despaisamento"185. Vale dizer: o sentido mesmo de quaisquer identidades e / ou alteridades que se construam é a "escavação" do tempo-espaço vivido, e, nesse sentido, a figuração ambivalente das "raízes" (desfigurando-as / transfigurando-as) é um recurso fundamental.

131. Ser tão sozinho em meio a tantos ombros,

132. andar aos mil num corpo só, franzino,

133. e ter braços enormes sobre as casas,

134. ter um pé em Guerrero e outro no Texas,

135. falar assim a chinês a maranhense,

136. a russo, a negro: ser um só de todos,

137. sem palavra, sem filtro,

138. sem opala:

139. há uma cidade em ti, que não sabemos.

O “tu” (“Carlito”) de "Canto ao homem do povo Charlie Chaplin”,

224. Poder da voz humana inventando novos vocábulos e dando sopro aos exaustos.

225. Dignidade da boca, aberta em ira justa e amor profundo,

\footnotetext{
${ }^{184}$ Referência ao poema, cujos primeiros versos retomam a exumação simbólica do Patriarca:

1. No país dos Andrades, onde o chão

2. É forrado pelo cobertor vermelho de meu pai,

3. indago um objeto desaparecido há trinta anos,

4. que não sei se furtaram, mas só acho formigas.
}

185 A expressão remete à primeira carta enviada por Mário de Andrade a Drummond, em 1924: “... li seu artigo. Está muito bom. Mas nele ressalta bem o que falta a você - espírito de mocidade brasileira. Está bom demais pra você. Quero dizer: está muito bem pensante, refletido, sereno, acomodado, justo, principalmente isso, escrito com grande espírito de justiça. Pois eu preferia que você dissesse asneiras, injustiças, maldades moças que nunca fizeram mal a quem sofre delas. Você é uma sólida inteligência e já muito bem mobiliada... à francesa. (...) Eu não amo o Brasil espiritualmente mais que a França ou a Conchinchina. Mas é no Brasil que me acontece viver e agora só no Brasil eu penso e por ele tudo sacrifiquei. (...) O importante não é ficar, é viver. Eu vivo. E vocês não vivem porque são uns despaisados e não têm a coragem suficiente pra serem vocês. É preciso que vocês se juntem a nós ou com este delírio religioso que é meu, do Osvaldo, de Tarsila, ou com a clara serenidade e deliciosa flexibilidade do pessoal do Rio, Graça, Ronald. De qualquer jeito porque não se trata de formar escola com um mestrão na frente. Trata-se de ser. E vocês por enquanto ainda não são." (A Lição do amigo: cartas de Mário de Andrade a Carlos Drummond de Andrade, anotadas pelo destinatário, p. $5-6)$ 
226. crispação do ser humano, árvore irritada, contra a miséria e a fúria dos ditadores,

é também um duplo do Gauche ${ }^{186}$,

3. ... um poeta brasileiro,

4. não dos maiores, porém dos mais expostos à galhofa,

5. ... esse pequeno cantor teimoso,

6. de ritmos elementares, vindo da cidadezinha do interior

7. $\quad$ onde nem sempre se usa gravata mas todos são extremamente polidos

8. e a opressão é detestada, se bem que o heroísmo se banhe em ironia,

um Mesmo e, a um tempo, um Outro. A identidade é muito forte, e enuncia-se em termos de um desenraizamento similar entre a gente de Carlos e a gente de Carlito:

13. como os brasileiros te amam

14. e que nisso, como em tudo mais, nossa gente se parece

15. com qualquer gente do mundo - inclusive os pequenos judeus

16. de bengalinha e chapéu-coco, sapatos compridos, olhos melancólicos,

17. vagabundos que o mundo repeliu, mas zombam e vivem

18. nos filmes, nas ruas tortas com tabuletas: Fábrica, Barbeiro, Polícia,

19. e vencem a fome, iludem a brutalidade, prolongam o amor

20. como um segredo dito no ouvido de um homem do povo caído na rua.

, desenraizamento esse que também se percebe na imagem do último verso do último poema de A rosa do povo (que é sempre a última imagem dos filmes protagonizados por Carlito):

226. ó Carlito, meu e nosso amigo, teus sapatos e teu bigode caminham numa estrada [de pó e esperança.

Esse ícone da cultura de massas do século XX, extremamente poderoso, tão poético quanto engajado, equivale ao desejo-imagem drummondiano, enunciado claramente em "Mas viveremos":

65. E ganhará enfim todos os portos,

66. avião sem bombas entre Natal e China,

67. petróleo, flores, crianças estudando,

${ }^{186}$ Cf. "Disfarces gauches", in Affonso Romano de SANT'ANNA, op. cit. p. 51-57. 
68. beijo de moça, trigo e sol nascendo.

69. Ele caminhará nas avenidas,

70. entrará nas casas, abolirá os mortos.

71. Ele viaja sempre, esse navio,

72. essa rosa, esse canto, essa palavra. ${ }^{187}$

Esse desejo-imagem enunciado pode esclarecer um outro poema, aparentemente hermético, se desvinculado do contexto (literário e / ou extra-literário) da coletânea:

$\begin{array}{ll}\text { 1. } & \text { O chinês deitado } \\ \text { 2. } & \text { no campo. O campo é azul, } \\ \text { 3. } & \text { roxo também. O campo, } \\ \text { 4. } & \text { o mundo e as coisas } \\ \text { 5. } & \text { têm ar de um chinês } \\ \text { 6. } & \text { deitado e que dorme. } \\ \text { 7. } & \text { Como saber se está sonhando? } \\ \text { 8. } & \text { O sono é perfeito. Formigas } \\ \text { 9. } & \text { crescem, estrelas latejam, } \\ \text { 10. } & \text { peixes são fluidos. } \\ \text { 11. } & \text { E árvores dizem qualquer coisa } \\ \text { 12. } & \text { que não entendes. Há um chinês } \\ \text { 13. } & \text { dormindo no campo. Há um campo } \\ \text { 14. } & \text { cheio de sono e antigas confidências. } \\ \text { 15. } & \text { Debruça-te no ouvido, ouve o murmúrio } \\ \text { 16. } & \text { do sono em marcha. Ouve a terra, as nuvens. } \\ \text { 17. } & \text { O campo está dormindo e forma um chinês } \\ \text { 18. } & \text { de suave rosto inclinado } \\ \text { 19. } & \text { no vão do tempo. }\end{array}$

O poema, acima transcrito com todos os seus versos (“Campo, chinês e sono”), perde um pouco a sua aura de exotismo puramente “ideogrâmico”, e nada referencial ${ }^{188}$,

\footnotetext{
187 Denotativamente, o desejo é algo a cumprir-se; conotativamente, porém (e, mesmo, em termos da "materialidade do texto", que é a sua realização formal), o desejo é algo muito "concretamente" realizado, pelo processo de significação do poema: veja-se a temporalidade do "presente ético" no v. 71 (Marcel CRESSOT, em O estilo e suas técnicas , p. 148, denomina "presente ético" ou "extratemporal" à temporalidade do verbo que indique "um fato permanente, ou uma verdade geral").

188 Iumna SIMON afirma: "queremos chamar atenção para a configuração ideogrâmica do poema 'Campo, Chinês e Sono' (dedicado a João Cabral de Melo Neto), em que os procedimentos a que estamos nos referindo [o 'fechamento do discurso'], especialmente os cortes rítmico-espaciais abruptos e a intersecção interna do verso por pausas gramaticais fortes (ponto final), estão a serviço da criação de uma linguagem essencialmente plástica, alcançada pela exploração da fanopéia (...). Como se pode notar, o movimento e metamorfose das imagens é atualizado por um processo de montagem em que os cortes metonímicos são efetuados justamente pelos 'enjambements' e pelas pausas gramaticais localizadas no interior dos versos (...). Através dos cortes sucessivos vão se operando as analogias e metamorfoses até chegar à metamorfose final (versos 17,18 e 19). Como resultado desse processo de montagem, temos a configuração visual de uma imagem global, em que se fundem e se superpõem as imagens particulares do 'campo', 'chinês', 'mundo' e 'todas as coisas', cuja matriz analógica é oferecida pelo processo onírico de 'condensação' e 'deslocamento' [referências a conceitos propostos por Freud em La interpretación de los sueños]. (op. cit., p. 184-185). "O poema
} 
quando se pensa que a resistência maoísta ao Eixo, durante a Segunda Guerra, mas também a possibilidade de romper com a história imperialista que já vinha do século XIX, certamente despertou o interesse vivo das esquerdas pelo mundo, sem que houvesse, entretanto, um mínimo de informação disponível a respeito no contexto ditatorial do Estado Novo - daí, a necessidade de recorrer à “imaginação” poética. Ademais, o poema parece ser mais um caso de “escavação do solo em direção à China”, cujo sentido transfigurador encontra eco em outros poemas, considerando-se o contexto da coletânea.

De resto, é procedente perceber que há, no livro, um movimento subjetivo, cujo sentido é a pluralidade temático-formal, mas que não perde de vista a coesão lírica, e que tem como problemática freqüente a sensação de insulamento, ora enunciada de modo evidente, ora denunciada por meio de "cifras”, o que guarda relação estrita, mas não imediata, com os eventos objetivos, nos quais a coletânea muito explicitamente se engaja.

seguinte, 'Campo, Chinês e Sono', é a procura da 'Vida Menor' ('mínima, essencial, um início, um sono;') posta em prática, embora, paradoxalmente, a metalinguagem do poema anterior ateste a 'desnecessidade do canto', ou seja, afirme a supremacia da vida sobre a arte, já que a vida é 'forma irredutível' ao canto - o silêncio da poesia." (idem, ibidem, p. 194) 


\section{CAPÍTULO 5}

\section{UMA VISÃO, OU TENTATIVA DE, DA EXISTÊNCIA}

(EM NOSSO TEMPO) 


\section{CAPÍTULO 5 - Uma visão, ou tentativa de, da existência (em nosso tempo)}

E a tristeza de deixar os irmãos me faça desejar partida menos imediata. Ah, podeis rir também, não da dissolução, mas do fato de alguém resistir-lhe, de outros virem depois, de todos sermos irmãos, no ódio, no amor, na incompreensão e no sublime cotidiano, tudo, mas tudo é nosso irmão. (Carlos Drummond de Andrade, “Os últimos dias”)

José Guilherme Merquior, em seu estudo sobre a obra drummondiana ${ }^{189}$, distingue quatro fases poéticas entre Alguma poesia (primeiro livro de poesia) e A falta que ama (último livro publicado até então). Num primeiro momento, entre 1925 e 1940 (reunindo portanto as seguintes coletâneas: Alguma poesia - de 1930; Brejo das Almas - de 1934; e Sentimento do mundo - de 1940), o percurso da subjetividade lírica vai, segundo Merquior, dum individualismo acentuado à ética do engajamento, relacionando sempre o plano da escrita com o plano do acontecimento, mas deixando a percepção da "vida besta” no sentido duma nova relação com o mundo, em que a solidão radical do indivíduo, embora permaneça, torna-se contudo objeto duma autocrítica acurada, oriunda do desejo de participar da transformação do mundo. Nesse mesmo percurso lírico, o estilo também se transforma, deixando os iniciais efeitos de distanciamento, provocados pela mescla estilística, em direção a um neo-romantismo carregado de pathos, embora não sentimental. O sentido sociológico desses movimentos corresponderia à dimensão, a um tempo biográfica e coletiva, das transformações nacionais: a mutação do patriarcalismo rural em virtude da industrialização e da urbanização. $^{190}$

Já o segundo momento da obra, entre 1941 (início da escrita dos poemas publicados em José, em 1942) e 1945 (ano de publicação de A rosa do povo),

\footnotetext{
189 José Guilherme MERQUIOR, Verso Universo em Drummond.

190 Idem, op. cit., p. 8-49.
} 
traz ao modernismo três conquistas decisivas para o desenvolvimento da literatura brasileira: um realismo social excepcionalmente penetrante, muito acima do lirismo declamatório da poesia engajada; uma poesia metapoética, nutrida de uma espécie de reflexão introspectiva da escrita; um lirismo, enfim, de interrogação existencial, preludiando o desenvolvimento do poema filosófico que caracterizará os livros posteriores como Claro Enigma.

É óbvio que essas contribuições ficariam no nível de simples curiosidades temáticas, se o estilo de Drummond não as tivesse tornado matéria-prima de um notável amadurecimento técnico. O autor de Alguma Poesia, modernista radical, era sobretudo uma voz original; o autor de A Rosa do Povo, conservando essa originalidade, torna-se o miglior fabro da poesia modernista.

\section{(...)}

Vindo após a "escorregadela" neo-romântica de Sentimento do Mundo, o lirismo de A Rosa do Povo se divide entre a ótica grotesca em "estilo mesclado" e um estilo "puro" não menos moderno. Desencadeia-se, assim, uma verdadeira classicização do modernismo, análoga, em certos aspectos, à evolução, por volta de 1930, do estilo poético de um T. S. Eliot, após a Stilmischung de The Waste Land. Sabe-se que tal classicização nada tem de "reacionária" do ponto de vista da técnica do verso. Em Drummond - e aqui termina a semelhança com Eliot - o novo estilo "puro" não trouxe consigo sequer uma "restauração ideológica". Bem ao contrário: como o provam sua "metapoesia" e seu lirismo filosófico-existencial, ambos escritos em estilo "puro" - a modernidade e a autonomia intelectual do lirismo drummondiano não cessam de crescer. ${ }^{191}$

Nesse sentido, então, a apreciação crítica da obra poética de Drummond, ao acompanhar os seus desdobramentos numa temporalidade cartesiana (lógico-linear, teleológica e “evolutiva”), vai da "juventude” à "maturidade” e, daí, à “velhice”. Assim, o tempo biográfico, o tempo bibliográfico e o tempo histórico-sociológico imbricam-se, sobrepostos, do que decorre a formulação de expressões como “o primeiro lirismo" e "o meio-dia da escrita".

José e A Rosa do Povo constituem o momento meridiano do lirismo de Drummond. É a idade média de sua obra, o luminoso meio-dia de sua expressão, que dirige o olhar ao mesmo tempo para trás, em direção ao humor ácido do seu estilo de juventude, e para a frente, para as nobres meditações clássicas de sua poesia outonal.

O estudo revela-se muito eficaz em verificar, analítico-descritivamente, aspectos estilísticos da obra drummondiana, mas perde força quando pretende interpretar os seus significados "sociológicos”, ou quando estabelece juízos de valor. (Tais juízos

\footnotetext{
${ }^{191}$ Idem, ibidem, p. 121, grifos do autor. Para o nosso estudo, importa comentar apenas estas duas primeiras "fases". A "terceira", conceituada por Merquior como "classicização do modernismo", comporta as coletâneas Novos Poemas (de 1948), Claro Enigma (de 1951), Fazendeiro do Ar (de 1953) e A Vida Passada a Limpo (de 1959). A "quarta" conceitua-se como "o último lirismo de Drummond" e comporta Lição de Coisas (de 1962), Boitempo e A Falta que Ama (ambos publicados no mesmo volume, em 1968).
} 
pretendem-se estéticos, mas demonstram-se, no final das contas, meras extensões de (pré-) conceitos políticos. ${ }^{192}$ )

Esta observação é pertinente porque o conceito que Merquior tem de “engajamento” poético é discutível, e não faz jus nem à importância contextual de $A$ rosa do povo (como conjunto literário e como intervenção no real “extra-literário”) nem à dimensão integral do seu valor estético (cujo fundamento é a pluralidade), e isso ocorre por diversas razões.

Em primeiro lugar, porque, ao identificar, analítico-descritivamente, aspectos estilísticos, Merquior não percebe nem se preocupa com as possíveis articulações significantes entre as suas múltiplas (mas justapostas) manifestações expressivas, quer no plano dos significados (“temático”), quer no plano do dinamismo artístico (“formal”) - e, assim, perde de vista o fundamento lírico drummondiano. Desconsiderar a pluralidade de manifestações estilísticas com fundamento lírico torna problemático o juízo de valor sobre os “estilos” (Merquior julga esteticamente positivas a “mescla” e a “classicização”, e esteticamente negativa a "escorregadela neo-romântica de Sentimento do Mundo”), como se houvesse “acertos” e “erros” literários pelo percurso poético, "felizmente" abandonados conforme o artista, ao "amadurecer", vai-se livrando de “pecados” e “ilusões” ideológicos da "juventude”.

Em segundo lugar, porque a sua própria proposta de abordagem, enunciada logo na "Introdução" ao seu estudo, se propunha a

... três finalidades. De início, trataremos de obedecer a um método essencialmente estilístico, buscando todos os conteúdos da poesia de Drummond no nível da organização verbal: mostrar o que diz a poesia é mostrar como o diz. Em seguida faremos um esforço no sentido de pôr em relevo a significação sociológica (sobretudo no que concerne à evolução do regime patriarcal no Brasil) e ideológica da obra de Drummond, já que se trata, sem dúvida, de uma poesia que é ao mesmo tempo um reflexo do mundo sócio-cultural e uma reflexão crítica sobre esse mesmo mundo - ainda que o reflexo não se degrade em documento ou ilustração, e que a reflexão jamais se apresente de forma abstrata e intelectualista. Finalmente, tentaremos pôr o lirismo drummondiano em relação com a literatura ocidental moderna, tanto do ponto de vista da técnica quanto do ponto de vista dos leitmotive ideológicos. Estes três objetivos constituem diferentes planos, e não momentos, da análise; serão perseguidos simultaneamente, ainda que de maneira desigual, ao longo de cada um dos quatro períodos do estilo poético de Drummond. ${ }^{193}$

\footnotetext{
192 Tratamos deste aspecto no capítulo 1, nota 44. Ver também as notas 102 e 109 do cap. 3.

193 Idem, ibidem, p. 3-4, grifos do autor.
} 
E, apesar do anúncio, a análise de aspectos do estilo, sempre arguta, cede lugar à leviandade nas considerações de aspectos “sociológicos” e “ideológicos” desprovidas de mediação, quando diz, por exemplo, que o Drummond de A rosa do povo é um “liberal de esquerda”194 (tendo entretanto constatado, momentos antes, “o intelectual marxizante que é Drummond nessa época [1943-1945]”195).

O estudioso, além de apreciações de fundo ideológico, estabelece juízos de valor sobre determinados procedimentos estilísticos, exaltando-os ou desconsiderando-os segundo pressupostos exteriores à obra, que dizem respeito, antes, ao conservadorismo do crítico e ao seu contexto (a guerra fria), pressupostos que contaminam, sem fundamento nem mediação, os planos da interpretação e do julgamento estético, prejudicando-os. Dessa forma, os poemas explicitamente engajados (a "lírica de guerra”, por exemplo, que Merquior considera “poemas declamatórios” ou “retóricos”) são tidos como ruins, como se o engajamento artístico fosse um entre diversos outros “temas”, não só desarticulado em relação aos demais como também mal resolvido em determinadas opções do poeta. ${ }^{196}$

Essa “articulação” entre os aspectos “sociológico-ideológicos” e "estilísticos” em Merquior, que de fato aparece na análise do "primeiro lirismo drummondiano" (identificando-se o percurso estilístico da lírica com o percurso da modernização brasileira), suspende-se na análise do “meio-dia da escrita” (quando, em lugar da relação texto / contexto, estabelecem-se juízos de valor de natureza estética, pautados por pressupostos ideológicos sem qualquer demonstração no plano “material” do texto).

\footnotetext{
194 "A ambivalência dos sentimentos de Drummond no que refere ao núcleo familiar e também aos antepassados parece no fundo confirmar sua posição particular de homem que cavalga dois mundos sociais, dois universos de cultura: o Brasil tradicional da fazenda e o Brasil moderno, urbanizado. O autor de $A$ Rosa do Povo não tem a sensibilidade conservadora de um Lins do Rego; é antes um intelectual socializante, se bem que seja bastante lúcido para falar no auge de seu engajamento ideológico - de "mitos" proletários (in "Idade Madura", RP, 186, v. 53); conservará sempre o estofo de um liberal de esquerda.” Idem, ibidem, p. 93, grifos do autor. 195 "O intelectual marxizante, que é Drummond nessa época, adota assim uma concepção humanista, moralista do processo social, concepção que tende (do mesmo modo que vários ramos do chamado "marxismo ocidental") a confundir de maneira ingênua o capitalismo com fenômenos "imorais" que, como a usura, antes pertencem a uma etapa pré-capitalista da economia e da sociedade. Desse modo não nos surpreenderemos ao encontrar a energia máxima do olhar sociológico de Drummond, não nessas prosopopéias antinegócio [o autor se refere a poemas como "Nosso tempo" e "Mas viveremos"], mas na elaboração poética de instantâneos realistas." Idem, ibidem, p. 79.

196 Quanto a esse tipo de abordagem, outro estudo tece observações críticas que nos parecem pertinentes (embora não concordemos nem com o seu método estruturalista de análise, nem com as suas premissas filosóficas, as quais, muitas vezes, antecipam-se à compreensão do processo poético e, com isso, limitam-na): "as divisões geralmente estipuladas como fases de sua poesia - a irônica (de Alguma Poesia a Brejo das Almas); a social (de Sentimento do Mundo a Rosa do Povo); a metafísica (de Claro enigma a Boitempo) - pareceram-me etapas artificiais, engendradas pelo vezo didático e pelo embaralhamento do que seja conjuntural e estrutural numa obra. Tripartido assim, Drummond seria apenas um autor fragmentário, e essa poética é, para usar uma linguagem heideggeriana, um 'projeto poético-pensante'." (Affonso Romano de SANT'ANNA, Drummond: o gauche no tempo, p. 13.)
} 
Em geral, a crítica considerou A Rosa do Povo como "poesia social” no sentido de arte engajada ${ }^{197}$, levando em conta sobretudo, se não exclusivamente, os trechos ideológicos e o lirismo "coral” dos poemas de guerra. Entretanto, como vimos, a profundidade maior, a dimensão verdadeiramente sociológica da visão social de Drummond, reside antes nos textos mais "subjetivos" como "A flor e a náusea”, "O mito” e os poemas do ciclo de Itabira. É preciso, pois, libertar a crítica do mau hábito de confundir o "social” em poesia com o "reflexo" da sociedade ou a propaganda ideológica. Tal como Theodor Adorno, polemizando contra esses equívocos gêmeos, o naturalismo e o "realismo socialista", nos advertiu, [o autor cita um trecho de Noten zur literatur, traduzindo-o em seguida:] (precisamente o que não é social no poema lírico deve ser seu elemento social). Não esqueçamos que a essência do lirismo é subjetivação (v. supra, p. 27), nem que o isolamento do eu é inerente ao discurso lírico (...). Não é nos seus hinos de guerra, não é sequer nos seus afrescos da sociedade de massa que Drummond aprofunda a significação social de sua obra - é antes no lirismo "individualista” das paixões do eu - e até mesmo no sentido cultural, no ethos crítico, esboçado por sua poesia filosófica. O realismo urbano, a evocação sociológica da vida patriarcal são firmemente construídos sobre o eixo subjetivo da linguagem lírica. ${ }^{198}$

A crer no que propõe Merquior, há uma parte de A rosa do povo literariamente válida, e outra parte "menor”, porque “ideológica” e "menos lírica”, “reflexo da sociedade”, parte esta em que se incluem os “poemas engajados”, isto é, os poemas que procuram se envolver explicitamente com eventos objetivos (quais sejam: a "guerra" e a "sociedade de massa”: note-se o sintomático silêncio de Merquior sobre a questão do nazifascismo como degradação das contradições do capitalismo). Assim, apenas os poemas "subjetivantes" - e os “filosóficos” - resultam "literária” e "sociologicamente maiores".

\footnotetext{
197 Neste momento, o texto de Merquior inclui a seguinte nota de rodapé, para nomear o que chama de "crítica": "A condenação do mundo injusto e a esperança de seu contrário são para Péricles Eugênio da Silva Ramos, "O Modernismo na Poesia", in A Literatura no Brasil (obra coletiva dirigida por Afrânio Coutinho), vol. V Ed. Sul Americana, Rio, 1979, pp. 125-127 - a tese geral do livro”. Não apenas em Ramos, mas também em Antonio Candido (no acima referido "Inquietudes na poesia de Drummond"), guardadas as suas especificidades teórico-metodológicas, o desejo de redenção do eu e do mundo é aspecto fundamental da obra drummondiana em $A$ rosa do povo, e é essa perspectiva, e não a de Merquior, que julgamos acertada. Cabe notar, entretanto, que a tese adorniana, se é contrária à perspectiva de Ramos, em nada contradiz a perspectiva de Antonio Candido, cuja epistemologia, com ser dialética (como, de resto, também a de Adorno, mas não suficientemente a de Merquior), logra alcançar os aspectos extra e intra literários da sincronia e da diacronia. Note-se, por fim, que não deve ser imediata, senão devidamente mediada, a transposição de corpos teóricos (cujos objetos de estudo são específicos) de um contexto a outro, sob pena de atropelar as historicidades e as especificidades estéticas em questão (tanto a do sistema epistemológico que se evoca quanto a da fonte literária a interpretar). Cf. Jean STAROBINSKI, "A literatura: o texto e o seu intérprete". In: Jacques LE GOFF e Pierre NORA, História: novas abordagens.

198 Idem, ibidem, p. 122.
} 
No nosso entendimento, entretanto, a resposta de Merquior a uma determinada crítica panfletária resulta apenas numa contra-face, que, com isso, não a supera (antes, a reforça).

Entre 1936 e 1939, ocorreu a Guerra Civil Espanhola, evento fundamental para que se intensificasse o fenômeno literário do “engajamento” por todo o mundo ${ }^{199}$. Mas o “engajamento literário”"200, embora mais intenso às vésperas da Segunda Guerra, remonta a um processo anterior, cujos desdobramentos imbricam-se, inclusive, nas origens sócio-culturais do nazi-fascismo. Trata-se das transformações radicais do universo mental no contexto da Revolução Científico-Tecnológica, desencadeada a partir de 1870, e que teve como resultado paroxístico as Catástrofes da "guerra tecnológica”201.

A chamada "arte moderna”, bem como todo o universo simbólico no Ocidente, entre fins do XIX e início do XX, empenhou-se em ressignificar a atitude do homem contemporâneo diante das mais diferentes problemáticas, tendo como fundo a perda do seu status de sacralidade e dignidade superior (atribuído, até então, à condição humana

\footnotetext{
199 Antonio CANDIDO, "Inquietudes na poesia de Drummond", in Vários escritos, p. 125.

200 O "engajamento literário", muitas vezes, significou, não apenas a participação mais ou menos imediata do texto num determinado contexto, mas também, no limite, o engajamento do próprio autor, "em pessoa", em eventos críticos como revoluções ou guerras. Apollinaire e Blaise Cendrars, por exemplo, lutaram na Primeira Guerra Mundial, e muitas características de estilo dos seus textos (o aspecto "telegráfico", entre outros), procuraram mimetizar vivências "objetivas", como forma de interferir, não apenas na sua representação simbólica, mas também no real concreto. Este é o sentido amplo da observação sobre as implicações radicais, para a literatura, do envolvimento mundial na Guerra Civil Espanhola. Acrescente-se a isso o fato de que, às vésperas da Segunda Guerra Mundial, os ânimos polarizaram-se entre os que tomaram partido a favor ou contra o nazi-fascismo. Assim, puderam agregar-se, em torno de opções dilemáticas (“ou isto ou aquilo"), visões de mundo discordantes (veja-se, por exemplo, o espectro que vai do liberalismo ao anarcosindicalismo, passando pelo marxismo-leninismo ou pelo trotskismo, a compor uma só frente em defesa dos Republicanos espanhóis, durante a Guerra Civil).

No Drummond de $A$ rosa do povo, o grande problema do "engajamento" não é o de escolher entre a "sociedade" ou a "literatura", mas o de optar pela defesa do "melhor" contra o "pior". Como toda idéia, em Drummond, tanto o "melhor" quanto o "pior" são julgamentos que desconfiam de si próprios, porque sabem-se (ou, antes, procuram saber-se) provisórios, relativos, e por isso a consciência crítica do lugar de onde se fala é tão fundamental. Este é um dos sentidos da "escavação" de sua identidade, que compõe a própria essência do gauchismo, ou descentramento.

${ }^{201}$ Nicolau SEVCENKO, Orfeu extático na metrópole, p. 156-161.
} 
nos seus mais diferentes aspectos, físicos ou metafísicos). ${ }^{202} \mathrm{O}$ contexto objetivo desses esforços foi a profunda reviravolta das estruturas sociais, em virtude da refacção das estruturas produtivas.

As descobertas científicas da segunda metade do XIX, aplicadas às necessidades da produção industrial, levaram ao emprego de novas fontes energéticas (o petróleo, a eletricidade) na produção de bens mercantis. Os grandes conglomerados produtivos, em substituição às pequenas unidades fabris, passaram a exigir um imenso volume de capitais como investimento inicial, originando a fusão entre os capitais dos grandes bancos e o das indústrias. Essa inusitada alteração nas estruturas produtivas provocou o surgimento das “cidades industriais”, megalópoles com uma tal concentração demográfica, sobretudo de operários, que as antigas formas de controle social (institucionais e territoriais) foram, necessariamente, refeitas, sob pena de não conseguir frear a organização das massas, que contestavam a situação opressiva a que se viam submetidas.

O antigo arcabouço liberal da livre-concorrência e da democracia censitária entrou em colapso nos “centros industriais”, dando lugar à cartelização dos mercados e à planificação da economia. A necessidade de ampliar os mercados consumidores levou ao investimento estatal na construção de uma malha de transportes e de uma rede de comunicações de massa cada vez mais tecnologicamente sofisticadas, servindo à circulação de pessoas, mercadorias e informações - o que passou a constituir fator decisivo nas guerras de novo tipo (disputas acirradas por territórios que fornecessem matéria-prima e mercado consumidor, antecipadas pela Guerra Franco-Prussiana de 1870 e intensificadas pelo imperialismo na África, na Ásia e na América Latina).

Nos territórios “periféricos”, aprofunda-se a divisão internacional do trabalho, com as colônias e ex-colônias especializando-se na monocultura dos produtos “exóticos” (estimulantes como café e chá, necessários ao novo cotidiano industrial). Acentuam-se as condições desiguais de troca entre os territórios economicamente “desenvolvidos” e os “subdesenvolvidos”, com o agravamento das condições de opressão à mão-de-obra na "periferia” monocultora. ${ }^{203}$

\footnotetext{
202 Na ressignificação do universo simbólico ocidental, além da "arte moderna", incluem-se a física após Max Planck e Einstein, a psiquiatria após Freud, os estudos lingüísticos após Saussure, a psicologia após Gustave Le Bon, a filosofia após Nietzsche, entre outros. (Idem, ibidem, p. 174-178)

${ }^{203}$ Idem, ibidem, p. 156-161.
} 
Na readequação das práticas simbólicas ao cotidiano industrial das megalópoles, profundamente transformado pelas novas tecnologias ${ }^{204}$ e pela lógica imperialista do capitalismo monopolista e financeiro, os antigos valores, assentados na palavra escrita e na racionalidade iluminista, cedem lugar a vitalismos e irracionalismos antiintelectualistas, que preconizam os impulsos instintivos, primários, a ação física, a força e a mobilização no sentido da ação coletiva e uniformizadora. Essa nova postura mental levou muitos europeus a buscar o "primitivo" e o "exótico”, em lugar da “civilização”, dirigindo-se às experiências humanas e físicas de outros continentes, ou então formulando novos sistemas conceituais (artísticos, científicos, filosóficos) que restaurassem o encanto perdido das experiências humanas.

Nesse processo, o acirramento das contradições capitalistas, quando engendram o conflito de proporções mundiais de 1914 a 1917, não contraria as expectativas das pessoas que ansiavam pela superação da “civilização corrompida” da Europa.

A Grande Guerra, portanto, ao contrário do que se poderia pensar, foi em grande parte ansiada e bem-vinda, o que ajuda a esclarecer o grande número de intelectuais e artistas, sem falar das milhares e milhares de pessoas anônimas que, apesar de sua intransigente índole humanitária, se alistaram voluntariamente para participar dela. Desejada e apresentada pela propaganda como "a última das guerras”, como a solução radical para os conflitos, os desequilíbrios e o mal-estar prevalecentes, como o momento redentor final de sacrifício para a construção de um novo mundo, mais livre e mais justo, ela, por grotesco que pareça hoje, foi deflagrada mobilizando esperanças. ${ }^{205}$

A referida "propaganda” tornou-se um braço institucional do poder, muito eficiente para os interesses estatais, cooptados pelo capital financeiro-monopolista, graças aos meios de comunicação de massa de então: fotografia, cinema e cartazes ${ }^{206}$.

\footnotetext{
204 A simples enumeração de produtos que invadiram o dia-a-dia urbano já sugere o impacto revolucionário da tecnologia no universo mental das pessoas, haja vista a: o telégrafo, o telefone, o aeroplano, o automóvel, a eletricidade doméstica, o fonógrafo, o cinema, o rádio, os elevadores, os refrigeradores, o raio-x, a radioatividade, a anestesia, as linhas de montagem, os transatlânticos, as motocicletas, as instalações de gás domésticas, os fogões, a máquina de costura, o aspirador de pó, as máquinas de lavar, as instalações sanitárias, o concreto armado, os alimentos enlatados, os refrigerantes, os sorvetes industrializados, as aspirinas, as lâmpadas elétricas, as máquinas de escrever e de calcular, a caixa registradora e o parque de diversões eletrificadas. (Idem, ibidem, p. 163.)

Não apenas essas transformações no plano do dia-a-dia, com a conseqüente perda das referências culturais, mas também o deslocamento de enormes massas de populações rurais no sentido das cidades (as de seu próprio país, ou então as de outros países em outros continentes), todos esses deslocamentos sociológicos e simbólicos configuram o "desenraizamento" do homem moderno, sobre o qual Walter Benjamin e a escola crítica de Frankfurt buscaram refletir. (Maria Odila Leite da SILVA DIAS, "Hermenêutica e narrativa", in SEVCENKO, op. cit., p. XIII.)

205 Nicolau SEVCENKO, op. cit., p. 164.

206 Idem, ibidem, p. 163-164. Diz o autor: "As modernas formas de comunicação de massas, a fotografia, o cinema e os cartazes reiteravam essa ênfase tecnológica sobre a ação e a velocidade, ressaltando ademais o
} 
Mas esse momento inicial [de contentamento com a Guerra] pouco durou e, quanto mais ela se delongava e mais pavorosa e insensata se tornava a carnificina, os sentimento iniciais iam se metamorfoseando no seu oposto, o desespero, o horror, o ódio visceral à ordem existente e um misto de cólera reprimida e impotência. (...)

Por outro lado, um novo mundo pôde desabrochar com a Guerra. Não com certeza o mundo mais perfeito que se ansiava, mas sem dúvida algo de muito novo. Foi no contexto da Guerra, por exemplo, que as novas técnicas de racionalização industrial e gerenciamento científico se consolidaram e obtiveram sua consagração definitiva dando pleno curso aos mercados de massa. Foi ela também que assentou em bases definitivas o planejamento econômico, definindo novas práticas intervencionistas, um novo estilo de liderança e toda uma nova concepção da ação estatal. Depois dela foram progressivamente democratizados o automóvel, as passagens transatlânticas e as remessas de avião. Mas foram também reforçados como nunca os prestígios carismáticos, as correntes irracionais, as submissões voluntárias aos apelos emocionais, sobretudo os de mais forte invocação instintual. Desespero, massificação, instinto e caos formavam uma combinação sui generis, embora também, para dizer o mínimo, deveras preocupante. Se o mundo de antes da Guerra comportava uma convulsão latente, a transpirar soturnamente em incidentes diários que carregavam presságios sombrios, após o armistício a convulsão era aberta, ampla e de conseqüências imprevisíveis. ${ }^{207}$

É do conflito, paradoxalmente amplificado pelo armistício injusto de 1919, que o processo cultural (do qual participaram as diversas vanguardas artísticas, a reformularse, e os movimentos sociais dos anos 1920) possibilita a formulação e a ascensão do fascismo. O vínculo entre as proposições futuristas de Marinetti (cujo Manifesto, precursor e inspirador do demais manifestos vanguardistas, remete a 1909) e a proposta fascista é muito estreito. O Futurismo, profundamente influenciado pelo Cubismo (nas vertentes posteriores a 1911, derivadas de Picasso e Braque, entretanto institucionalizadas e redirecionadas no sentido do abstrato e do funcional), bem como todas as vertentes vanguardistas (que, embora inspiradas no movimento cultural da Paris boêmia e anarquista, motivaram construções identitárias “nativistas” por todo o mundo)

papel privilegiado concedido nessa nova ordem cultural à imagem, à luz e à visualidade. É sabido o quanto essas três formas de comunicação incidem, mobilizam e demandam relações com as camadas mais profundas do subconsciente e como possuem o poder de causar impressões de grande magnitude em função do uso de prodigiosos efeitos de luz e do chamado realismo mecânico, a mágica verossimilhança obtida pelas técnicas fotográficas. Sem considerarmos esse poder irresistível da fotografia, do cinema e do cartaz, não se poderia compreender a amplitude, rapidez e persistência, apesar do morticínio atroz, das vastas mobilizações demandadas pelo esforço de guerra, assentada sobre três fatores-chave - a grande indústria, a rede de comunicações e a propaganda -, resultando no que foi chamado pela primeira vez de 'guerra total', por envolver simultaneamente o front e o cotidiano das populações civis num único e grande movimento, elétrica e mecanicamente coordenado. As fotografias, cartões-postais e filmes preencheriam igualmente a nostalgia, as carências afetivas e saudades dos que foram e daqueles que ficaram, dando origem ao controle político das imagens em função dos estados de ânimo desejáveis. No caso dos filmes, essas práticas justificariam plenamente o cognome atribuído ao sistema vigiado e codificado de produção dos filmes de Hollywood, como a "fábrica de sonhos'. Todos esses processos atingiram seus ápices de perfeição, porém, no contexto turbulento do período do pós-guerra.” (p. 164)

${ }^{207}$ Nicolau SEVCENKO, op. cit., p. 164. 
- todas essas vanguardas, européias e mundiais, de certa maneira participam do irracionalismo vitalista que, em determinadas vertentes, intensificou a metamorfose da “civilização corrompida” pela guerra. ${ }^{208}$

Assim, de maneira mais ou menos mediada, as transformações na estrutura produtiva, na organização social e no universo das representações e das práticas simbólicas comportaram um elemento implosivo, cujo marco sócio-político foi a Primeira Guerra de 1914 e cujo marco cultural foi o balé Parade, encenado em 1917 (tendo envolvido os esforços de Jean Cocteau, Picasso, Diaghliev, Eric Satie e Apollinaire). Esses dois marcos, que inauguram historicamente o século XX, encaminharam os sentidos artísticos e científico-filosóficos das mentalidades numa direção bastante específica, e conflituosa. ${ }^{209}$

É nos "heróicos" anos 1920 que vamos encontrar no Brasil os esforços modernistas no sentido de repensar os destinos cultural - e sócio-político - do país. As origens européias (sobretudo parisienses) da arte moderna inspiraram intelectuais (como Sérgio Buarque de Holanda), artistas (como Oswald e Mário de Andrade, e Tarsila do Amaral) e políticos (como Paulo Prado e Washington Luís, em São Paulo, e Gustavo Capanema, em Minas) a interferir na realidade brasileira. E, de fato, a experiência metropolitana de São Paulo (as práticas culturais populares, apropriadas pelos braços institucionais da política pública e pelos artistas, que se “engajam” na ressignificação dos valores oligárquico-burgueses da República Velha) encontra-se numa das raízes do movimento que termina por levar, em 1930, Getúlio Vargas ao poder. ${ }^{210}$

É preciso notar, entretanto, que o que se chama, indiscriminadamente, de “modernismo” no Brasil, é um conjunto de características estilísticas e ideológicas muito heterogêneo, que remonta a toda a vastidão espacial e cultural do território brasileiro, e que, a despeito da(s) matriz(es) comum(ns) (estético-ideológica(s)), guarda caminhos e significados suficientemente diversos entre si. Para ficar apenas no caso paulistano, cujo papel de liderança nacional (muitas vezes, em caráter “imperialista”) é indubitável, as suas origens ${ }^{211}$ comportaram uma inicial necessidade ideológica de

\footnotetext{
${ }^{208}$ Idem, ibidem, p. 182-222.

209 Idem, ibidem, p. 182.

210 Idem, ibidem, p. 23-151, 223-307. Para a experiência de Gustavo Capanema no chamado "modernismo mineiro" e, depois, no governo Vargas, cf. Helena BOMENY, Guardiães da razão: modernistas mineiros; Ângela GOMES et alli, Capanema: o ministro e seu ministério; Simon SCHWARTZMANN, Tempos de Capanema; Lúcia Lippi OLIVEIRA et alli, Estado Novo: ideologia e poder.

211 No capítulo 4, Sevcenko analisa, no contexto das apresentações e exposições promovidas por Paulo Prado para a elite plutocrática paulistana no Teatro Municipal, a montagem dramático-musical de $O$ contratador de diamantes, em 1919, obra póstuma que Afonso Arinos compôs antes de 1916, ano de sua morte. O autor é um
} 
confrontar, nos anos 1920, os questionamentos da população marginalizada pelo processo urbano-industrial contemporâneo, isto é, os imigrantes (sobretudo) e os migrantes (a população rural de ex-escravos e “caipiras”). ${ }^{212}$ Entretanto, a despeito dos caminhos ainda mais radicalmente conservadores que tomaram alguns dos movimentos subseqüentes (vejam-se o Verde-Amarelismo, a Escola da Anta e o Integralismo), vale notar o esforço de intelectuais como Sérgio Buarque de Holanda no sentido de rechaçar a xenofobia e o adesismo vitalista, colocando-se criticamente contra a construção dum passado (supostamente) tradicional (que é, na verdade, mistificador, e que, ideologicamente, põe-se ao serviço de interesses escusos). ${ }^{213}$

É nesses contextos que se faz necessário situar as - sempre plurais - escolhas estilísticas dos diferentes "momentos" drummondianos (que se esboçam nos anos 1920), bem como as “excentricidades” das suas posições biográficas e bibliográficas, não raro contraditórias ${ }^{214}$.

Falo do perigo de misturar desde o começo do raciocínio a instância de verificação com a instância de avaliação. O papel social, a situação de classe, a dependência burocrática, a tonalidade política - tudo entra de modo decisivo na constituição do ato e do texto de um intelectual. Mas nem por isso vale como critério absoluto para os avaliar. A avaliação é uma segunda etapa e não pode decorrer mecanicamente da primeira. (...) Mas o fato é que no processo estão envolvidos os homens, com a sua carne e a sua alma, de modo que conviria acentuar mais que um Carlos Drummond de Andrade "serviu" o Estado Novo como o funcionário que já era antes dele, mas não alienou por isso a menor parcela da sua dignidade ou autonomia mental. Tanto assim que as suas idéias contrárias eram patentes e foi como membro do Gabinete do Ministro Capanema que publicou os versos revolucionários de Sentimento do mundo $e$ compôs os de A rosa do povo. Já um Cassiano Ricardo se enquadrou ideologicamente e apoiou pela palavra e a ação, porque o regime correspondia à sua noção de democracia autoritária e nacionalista, devido a motivos que Micelli aponta muito bem no Capítulo I. Outros que nem vale a pena nomear, para poderem repousar com menos infelicidade no seio de Deus, eram pura e simplesmente escribas vendidos, sem alma nem fé.

(...) Sempre me intrigou o fato de um país novo como o Brasil, e num século como o nosso, a ficção, a poesia, o teatro produzirem a maioria das obras de valor no tema da decadência, - social, familiar, pessoal. Assim vemos em Graciliano Ramos, José Lins do Rego, Érico Veríssimo, Ciro dos Anjos,

dos precursores da investigação e da representação de aspectos da cultura popular brasileira e, segundo a análise de Sevcenko, um dos sentidos seus, especialmente a sua apropriação nos anos 1920, vai na mesma direção ideológica do mito do bandeirante paulista: o conservadorismo nacionalista, xenófobo e mistificador. Nicolau SEVCENKO, op. cit., p. 223-313.

212 Idem, ibidem, p. 23-151, 223-307.

${ }^{213}$ Idem, ibidem, p. 309-313. Cf., ainda, Antonio CANDIDO, “O significado de 'Raízes do Brasil' ”, in Sérgio BUARQUE DE HOLANDA, Raízes do Brasil, p. 9-21.

214 Ou "reflexivas", no conceito proposto por Davi ARRIGUCCI Jr., in Coração partido. 
Lúcio Cardoso, Nelson Rodrigues, Jorge Andrade, Manuel Bandeira, Carlos Drummond de Andrade. Cheguei a pensar que este "estigma” (para usar uma palavra prezada por Micelli) seria quase requisito para produzir obras valiosas, e que portanto os rebentos das famílias mais velhas estariam no caso em situação favorável.

Micelli sente coisa parecida e efetua a respeito uma análise interessante, não tanto no plano literário, que entra de esguelha, mas no do destino social e mental (digamos assim), mostrando como do declínio social se nutriram os quadros governamentais depois de 1930, quando o abalo das estruturas tradicionais e o predomínio do ritmo urbano suscitam novos tipos de clientela, patronato, dependência e concepção do trabalho. ${ }^{215}$

Na seção “Amar amaro” de sua Antologia poética, Drummond reuniu os seguintes poemas (nesta mesma seqüência): “Coração numeroso” (de Alguma poesia), "Sentimento do mundo" (de Sentimento do mundo), "Lembrança do mundo antigo" (idem), “Elegia 1938” (idem), “Mãos dadas” (idem), “Congresso Internacional do medo" (idem), “Nosso tempo" (de A rosa do povo), “O elefante” (idem), “Desaparecimento de Luísa Porto” (de Novos poemas), “Morte do leiteiro” (de A rosa do povo), "Os ombros suportam o mundo" (de Sentimento do mundo), "Anúncio da rosa” (de A rosa do povo), "Contemplação no banco” (de Claro enigma) e "Canção amiga” (de Novos poemas). ${ }^{216}$

Em que pese a sugestão “temática” sugerida pelo título “Amar amaro” (ou “O conhecimento amoroso”) ${ }^{217}$, o que há de “tematicamente” comum entre os poemas é o

\footnotetext{
215 Prefácio de Antonio Candido a Sérgio MICELI, Intelectuais e classe dirigente no Brasil, p. XI-XIII. À colocação de Antonio Candido, entretanto, não corresponde o julgamento taxativo de Simon SCHWARTZMANN (in Tempos de Capanema, p. 24): "Refazer o lado pessoal e mais profundo do relacionamento entre estes dois homens igualmente reservados, inteligentes e igualmente vitoriosos em suas respectivas carreiras exigiria muito mais do poderíamos pretender. Basta dizer que os dois, de alguma forma, se complementavam. Capanema, homem de cultura humanística e pretensões intelectuais, dedica-se inteiramente à política, sem uma obra intelectual própria que ultrapasse os limites do que os seus diversos cargos exigiam; Drummond, mais do que simples funcionário público, teria podido, quem sabe, seguir uma carreira política própria, que prefere, aparentemente, não realizar, em benefício de sua obra literária. É como se Capanema fizesse a política de Drummond, e este realizasse as ambições intelectuais do chefe e amigo." Ressalte-se, entretanto, que o seu estudo não tem como preocupação central analisar a biografia de Drummond, nem tampouco se debruça sobre a sua obra literária, atendo-se de passagem à sua atuação, como chefe de gabinete, no ministério de Capanema (este, sim, o seu verdadeiro objeto de estudo).

${ }^{216}$ Carlos DRUMMOND DE ANDRADE, Antologia poética, p. 95-119.

217 Iumna SIMON, em Drummond: uma poética do risco, p. 60-61, reuniu, sob a categoria "Amar amaro", os poemas "O mito" e "Caso do vestido" de A rosa do povo (poemas que, conforme vimos, Drummond, diferentemente, reuniu em "Uma, duas argolinhas"). Deduz-se que, para a estudiosa, o sentido de "Amar
} 
“sentimento do mundo”, ele mesmo um impulso de natureza erótica, mas no seu sentido mais amplo, que faz transigirem as dimensões da subjetividade particular e do "mundo grande”.

E em que pese, também, a sugestão do título de outra seção dessa mesma Antologia (“Uma visão, ou tentativa de, da existência”), não há, nesta ou em qualquer outra seção, um caminho filosófico-existencial como contraponto absenteísta ao “engajamento” nos eventos conjunturais ${ }^{218}$. Em “Amar amaro”, por exemplo, o que há, de fato, é um confronto entre a subjetividade (explícita ou implícita) e o mundo “exterior”, através do qual a(s) persona(e) lírica(s) constata(m) a precariedade recíproca de eu e mundo, sob o desejo mitopoético da completude ${ }^{219}$.

Esse confronto comporta múltiplos movimentos figurativos. Em alguns poemas, nota-se a afirmação do indivíduo sobre o mundo (é o caso de “Coração numeroso”, “Desaparecimento de Luísa Porto” e “Contemplação no banco”); em outros, notam-se figurações, alusivas ou explícitas, de eventos da macropolítica (vejam-se todos os poemas de Sentimento do mundo e A rosa do povo, que constam da seção); mas todos esses movimentos, entretanto, não anulam, antes pressupõem, os recursos líricos do gauchismo. E em todos eles, o “(res)sentimento do mundo” figura-se por meio de referências à temporalidade do dia-a-dia, evitando (ou deplorando) o monumental e o sobre-humano, segundo a escala individual do lirismo.

Há sempre um descompasso entre o indivíduo e o mundo, mesmo nos poemas que enunciam o engajamento. Nesses poemas, a figura do “canto” nunca comporta a coincidência entre eu e mundo ${ }^{220}$, e essa é uma maneira literária eficaz de redimi-los.

amaro" decorreria da problemática do amor propriamente erótico, o que, de fato, vem sugerido na Antologia, embora o seu sentido termine por assumir outra direção.

218 A opção pelo "fechamento do discurso sobre si mesmo" como recusa à "participação" e à "comunicação" é o sentido que Iumna SIMON atribui aos poemas aparentemente herméticos de $A$ rosa do povo, que, segundo ela, antecipam as opções de Claro enigma (op. cit., p. 201), o que, a nosso ver, é anacrônico. O livro de 1951 de fato sugere o absenteísmo, ao exibir como epígrafe o verso de Paul Valéry "Les événements m'ennuient." (Os acontecimentos me entediam."); mas o tom solene de melancolia e desprezo pela conjuntura, bem como o estilo "classicizante" ou "formalista", entretanto, não ocorrem no livro de 1945 em nenhum momento. Em $A$ rosa do povo, alguns poemas (como "Vida menor" ou "Nova canção do exílio") aproximam-se de um tom desesperado e / ou elegíaco, mas não há, no livro, opção por elementos “classicizantes", quando, ao contrário, o que se vê é o sarcasmo com as formas "clássicas" (o "soneto", por exemplo) e com o formalismo (a recusa da historicidade, e a busca do sublime).

219 Alcides VILLAÇA, "Capítulo drummondiano" (in Lendo poetas brasileiros).

220 Segundo Affonso Romano de SANT'ANNA (op. cit., p. 15), "A visão segmentada da poética drummoniana, seja por aqueles que mal viram o conjunto, seja por aqueles que se retiveram em pormenores, deve-se ao fato de não se ter percebido um dado básico: a estrutura dramática dessa obra onde há nitidamente um personagem (o poeta gauche) disfarçado em heterônimos (José, Carlos, Carlito, K., Robinson Crusoé etc.), descrevendo uma ação no tempo e espaço concebidos como um continum. O poeta se diversificou em egos auxiliares dentro da própria cena para conhecer os múltiplos aspectos de seu Ser, mas, ao se disfarçar em vários atores, não deixa nunca de ser espectador e crítico de seu próprio drama existencial." 
Desfigurados, eu e mundo refazem-se noutros termos, não como identidade imediata (sempre impossível), mas como mediação (sempre, o campo das possibilidades) ${ }^{221}$. É o que se vê nas imagens do "elefante”, da “flor”, do “tempo” e da “cidade”.

O descompasso entre eu e mundo se faz por diferentes recursos literários, que, entretanto, comportam sempre um mesmo (mas identitariamente complexo) personagem, o Gauche. Assim, sabe-se, já no plano denotativo, que o "elefante” é a representação (que se explicita enquanto tal) do intuito lírico redentor, como também o fazem outras personae. A primeira pessoa do singular (de "Coração numeroso", "Sentimento do mundo", "Mãos dadas”, “Nosso tempo”, “O elefante”, “Desaparecimento de Luísa Porto”, “Anúncio da rosa”, “Contemplação no banco” e “Canção amiga”) também se encontra, em aspectos ou sob disfarce, na segunda pessoa dialogal (de "Elegia 1938”, “Nosso tempo”, “Desaparecimento de Luísa Porto”, “Os ombros suportam o mundo”, “Anúncio da rosa” e "Contemplação no banco”), na terceira pessoa (de "Lembrança do mundo antigo”, “O elefante”, "Desaparecimento de Luísa Porto”, "Morte do leiteiro”, “Os ombros suportam o mundo” e "Contemplação no banco") e, por fim, na primeira do plural (de "Mãos dadas”, "Nosso tempo”, Desaparecimento de Luísa Porto”, “Morte do leiteiro”, “Anúncio da rosa” e “Canção amiga”).

Por sob a condição solitária do(s) indivíduo(s), figura-se a possibilidade (sob mediação) do encontro. A multiplicação de indivíduos, paradoxalmente, não anula o lirismo, antes o enriquece, e torna complexa a identidade do "eu”, mediante a pluralidade de papéis. A aparente despersonalização (o “desaparecimento" de personagens, como Luísa Porto ou o anônimo leiteiro) termina por reforçar a condição lírica. Denunciando-se a condição reificada da persona lírica (ou do seu disfarce em personagem), prepara-se a superação da "noite” (do impasse, que se desfigura) pela sua transfiguração em “aurora” (ou “flor”).

A “noite” tem uma importância figurativa muito grande, tanto em “Amar amaro” quanto em outras seções (e, como vimos, em A rosa do povo). Como uma espécie de

\footnotetext{
221 “... entre 1935 e 1959, há nele [na obra de Drummond] uma espécie de desconfiança aguda em relação ao que diz e faz. Se aborda o ser, imediatamente lhe ocorre que seria mais válido tratar do mundo; se aborda o mundo, que melhor fora limitar-se ao modo de ser. E a poesia parece desfazer-se como registro para tornarse um processo, justificado na medida em que institui um objeto novo, elaborado à custa da desfiguração, ou mesmo destruição ritual do ser e do mundo, para refazê-los no plano estético. Mas este distanciamento em relação ao objeto da criação agrava a dúvida e conduz outra vez o poeta a abordar o ser e o mundo no estado pré-poético de material bruto, que talvez pudesse ter mantido em primeiro plano, conservando o ato criador na categoria de mero registro ou notação. (Antonio CANDIDO, "Inquietudes na poesia de Drummond", in Vários escritos, p. 111)
} 
campo semântico, ela abarca os impulsos contrários ao encontro (“tanáticos”), e, assim, se dá a figuração da "guerra”, do "medo" (como princípio associal), da solidão, da interdição, do suicídio, do homicídio e de outras formas de morte, literais ou metafóricas. De todo modo, como não há coincidência entre eu e mundo, mas distanciamento (inclusive, nos próprios enunciados metapoéticos do lirismo), o "canto" invariavelmente desfigura-se, reflexivo, como forma de transfigurar a precariedade enunciada. Dessa forma, a “noite” prepara o "amanhecer”, superando-se a percepção de um tempo fragmentário.

Esse tempo, figurado em “cacos”, é o tempo vivido pelo eu lírico em toda a sua precariedade (tanto a de seu universo subjetivo quanto a de sua contra-parte objetiva). A figuração do "tempo partido", paradoxalmente, é uma forma muito eficaz de compreender, por recursos lingüísticos, o sem-sentido da contemporaneidade empobrecida (em seus aspectos subjetivos e objetivos) e, com isso, transfigurá-lo.

O sentido desse tempo vivido é, então, num nível imediato, o de pedaços (ou “cotas”) desprovidos de significado. Mas o seu sentido mediado (pelo “canto”, que é sempre metapoético, ou reflexivo), é o da transfiguração do impasse em possibilidade transitiva. Assim, a temporalidade dos sentidos costumeiros passa a incorporar, também, a possibilidade de confirmar, ou abandonar, certos hábitos, em função das necessidades vividas no aqui-agora. O “tempo presente”, marcado pela interdição, busca uma outra temporalidade, em que os sentidos herdados possam refazer-se, ou confirmar-se, no campo das possibilidades, que é o universo simbólico das escolhas, e, com isso, possam articular-se as esferas do habitual e do devir, numa escala que é a do vivido e do indivíduo. A sua identidade, que comporta o universo dos valores aprendidos diante dos papéis possíveis em diferentes situações sociais (da solidão pessoal às transigências coletivas), só se pode construir, como reificação ou como possibilidades, na escala do vivido. É por isso que, em “Amar amaro”, como também em A rosa do povo, o indivíduo e a sua experiência - no “tempo presente” - estabelecem uma perspectiva fundamental. 
“Nosso tempo" é um poema central em “Amar amaro"222, simbólica e literalmente. Na seqüência dos catorze poemas da seção, ele ocupa a sétima posição, e em termos de "sentimento do mundo", é o poema que melhor compreende o (sem-) sentido “[d']o tempo presente, [d']os homens presentes, [d']a vida presente"223. Ao figurar a reificação do indivíduo em diversos momentos do espaço-tempo urbanoindustrial (problemática que, de certo modo, organiza todos os outros poemas da seção), “Nosso tempo” torna-se uma espécie - paradoxal - de "precária síntese”. ${ }^{224}$

10. Visito os fatos, não te encontro.

11. Onde te ocultas, precária síntese,

12. penhor de meu sono, luz

13. dormindo acesa na varanda?

14. Miúdas certezas de empréstimo, nenhum beijo

15. sobe ao ombro para contar-me

16. a cidade dos homens completos.

A mimese do tempo fragmentário se faz pelo uso obsessivo do enjambement, pela sintaxe entrecortada, pelas partes que (des)estruturam o poema (são oito), pelo campo semântico (“esmigalhar”: v. 5, “explodir”: v. 25, “espandongar”: v. 110, etc.) e por diversos recursos expressivos que resultam na pluralidade formal como fator de coerência (em contraste com a despersonalização da subjetividade gauche) e na escala lírica como fator de coesão. ${ }^{225}$

Trata-se de um poema em que dois níveis se confrontam. No nível imediato, a pluralidade de recursos estilísticos e a procura - frustrada - pela completude levam à

222 Carlos DRUMMOND DE ANDRADE, Antologia poética, p. 95-119.

223 Últimos versos de "Mãos dadas":

12. O tempo é minha matéria, o tempo presente, os homens presentes,

13. a vida presente.

${ }^{224}$ Se "Nosso tempo" ocupa a posição literalmente central em "Amar amaro", a seção, por sua vez, é também o "centro" da Antologia poética, que tem quatro seções anteriores ("Um eu todo retorcido", "Uma província: esta", "A família que me dei", "Cantar de amigos") e quatro seções posteriores ("Uma, duas argolinhas", "Poesia contemplada", "Na praça de convites" e "Tentativa de exploração e de interpretação do estar-nomundo"). Considerando-se, ainda, que o sentido de "Amar amaro" é o "sentimento do mundo", e que essa expressão equivale ao conceito de "inquietudes", proposto por Antonio Candido como o fundamento da poética drummondiana entre 1935 e 1959 ("Inquietudes na poética de Drummond”, in Vários escritos, p. 111), a "centralidade" do poema "Nosso tempo" resulta ainda mais significativa.

${ }^{225}$ Em "Nosso tempo", a subjetividade lírica flana por lugares dum espaço urbano-industrial com os quais é impossível identificar-se. Por isso, deixa progressivamente de enunciar-se em primeira pessoa para, aos poucos, referir-se a si própria como a uma terceira pessoa, o que, como temos visto, configura um dos recursos do gauchismo drummondiano. 
enunciação de que as experiências subjetivas não podem ser "contadas", nem sequer formuladas. Os gestos, os espaços, os objetos, os próprios corpos, a linguagem - todos os signos, enfim, a que poderiam ser atribuídos significados, sofrem uma operação que os mutila, impedindo-os portanto de significar. As camadas significantes vêem-se apartadas dos significados, processo que o próprio lirismo tenta compreender, mimetizando-o.

35. Símbolos obscuros se multiplicam.

36. Guerra, verdade, flores?

37. Dos laboratórios platônicos mobilizados

38. vem um sopro que cresta as faces

39. e dissipa, na praia, as palavras.

O nível da denotação enuncia que a narrativa faz-se impossível, uma vez que o esvaziamento dos significados impede quaisquer articulações entre a subjetividade lírica, outras subjetividades e o espaço objetivo. Em outras palavras, o trânsito dos sentidos entre as subjetividades e o espaço vivido encontra-se interdito. As imagens que surgem aos fragmentos, e que, justapostas, não estabelecem entre si um nexo outro que não a perda de significado, terminam por configurar um processo analítico, decomponente.

52. Certas histórias não se perderam.

53. Conheço bem esta casa,

54. pela direita entra-se, pela esquerda sobe-se,

55. a sala grande conduz a quartos terríveis,

56. como o do enterro que não foi feito, do corpo esquecido na mesa,

57. conduz à copa de frutas ácidas,

58. ao claro jardim central, à água

59. que goteja e segreda

60. o incesto, a bênção, a partida,

61. conduz às celas fechadas, que contêm:

62. papéis?

63. crimes?

64. moedas?

O verso 52 é bastante irônico em seu enunciado, uma vez que as "histórias” não serão apresentadas por narrativas, a despeito do desejo lírico, mas por descrições da “casa”, cujos espaços são antes inquiridos que identificados. A memória evoca incógnitas, traumas e interditos, mas não significados. 
65. Ó conta, velha preta, ó jornalista, poeta, pequeno historiador urbano,

66. ó surdo-mudo, depositário de meus desfalecimentos, abre-te e conta,

67. moça presa, na memória, velho aleijado, baratas dos arquivos, portas

[rangentes, solidão e asco,

68. pessoas e coisas enigmáticas, contai,

69. capa de poeira dos pianos desmantelados, contai;

70. velhos selos do imperador, aparelhos de porcelana partidos, contai;

71. ossos na rua, fragmentos de jornal, colchetes no chão da costureira, luto

[no braço, pombas cães errantes, animais caçados, contai.

72. Tudo tão difícil depois que vos calastes...

73. E muitos de vós nunca se abriram.

No "tempo presente", as memórias do patriarcalismo convertem-se apenas em significantes desprovidos de significados.

136. Nos porões da família,

137. orquídeas e opções

138. de compra e desquite.

139. A gravidez elétrica

140. já não traz delíquios.

141. Crianças alérgicas

142. trocam-se; reformam-se.

143. Há uma implacável

144. guerra às baratas.

145. Contam-se histórias

146. por correspondência.

147. A mesa reúne

148. um copo, uma faca,

149. e a cama devora

150. tua solidão.

151. Salva-se a honra

152. e a herança do gado.

Pelo visto, o processo de esvaziamento dos significados, que se dirige às experiências pretéritas, situa-se no "nosso tempo" (um "presente” interdito, a partir do qual não é possível construir memórias e, tampouco, vislumbrar perspectivas futuras). Significantes desprovidos de significados (que não aqueles pré-estabelecidos pela lógica utilitária, “objetiva” - dessubjetivados portanto) caracterizam, de fato, o "tempo presente”, em que as memórias reificam-se, e em que o (sem-)sentido das “coisas” está dado, não pela transmissão de experiências subjetivas, mas pela lógica da transmissão da propriedade privada. (A justaposição de "honra” e "herança do gado" 226 , e

226 O substantivo concreto "gado", em mesma posição sintática que o abstrato "honra", faz com que os termos equivalham-se na condição de coisa ("reificação"). 
“orquídeas e opções / de compra e desquite”, é bastante eloqüente a respeito do ethos das “novas” relações familiares, assentadas na atomização e no funcionalismo.)

O que se percebe, então, no nível imediato do enunciado, é a (des)figuração mimética do processo contemporâneo de produção dum (sem-)sentido pelo (o nome é, em si, expressivo) "negócio” (v. 104), e pelo seu ethos tecnocrático. Por sob a “descritividade” mimética, entretanto, denuncia-se, numa síntese paradoxal, a racionalidade da reificação (irracional, portanto, segundo o ponto de vista das necessidades subjetivas). Entre os versos 136-152, a "funcionalidade" dos metros curtos é um recurso, mais que irônico, sarcástico. As "histórias" que "contam-se por correspondência” são tão significativas da despersonalização quanto reveladoras da "minha face trocista, / meu olho que ri e despreza, / minha repugnância total por vosso lirismo deteriorado, / que polui a essência mesma dos diamantes.” (v. 171-174).

7. As leis não bastam. Os lírios não nascem

8. da lei. Meu nome é tumulto, e escreve-se

9. na pedra.

$\mathrm{O}$ ataque a um dos fundamentos ideológicos (metonimicamente nomeado como “leis”) da sociedade burguesa reificada, antípoda da perspectiva lírica (isto é, subjetiva), leva à figuração (também metonímica) do “poeta” e do seu “canto” (reduzido a “palavras”):

17. Calo-me, espero, decifro.

18. As coisas talvez melhorem.

19. São tão fortes as coisas!

20. Mas eu não sou as coisas e me revolto.

21. Tenho palavras em mim buscando canal,

22. são roucas e duras,

23. irritadas, enérgicas,

24. comprimidas há tanto tempo,

25. perderam o sentido, apenas querem explodir.

O sentido lírico da "explosão”, se por um lado sintetiza uma poética que figura, metalingüisticamente, a fragmentação do sentido por processos analíticos, por outro põe os recursos do gauchismo a serviço da nomeação (apenas aparentemente descritiva) da “marcha do mundo capitalista”. 
175. O poeta

176. declina de toda responsabilidade

177. na marcha do mundo capitalista

178. e com suas palavras, intuições, símbolos e outras armas

179. promete ajudar

180. a destruí-lo

181. como uma pedreira, uma floresta,

182. um verme.

A enunciação da promessa nos versos finais do poema, bastante consciente da sua própria impotência (nota-se a despersonalização da subjetividade lírica como uma terceira pessoa), paradoxalmente tem o poder reversivo de transfigurar, numa síntese, todo o percurso metapoético anterior, em que os fragmentos significantes, miméticos quanto aos aspectos absurdos do "tempo presente", terminam por articular-se analogicamente, através da justaposição de imagens e da transposição metafórica de sentidos. O resultado lírico, então, não se vê restrito pelo nível analítico da denúnciadesfiguração do sem-sentido, mas complementa-se com o nível sintético-transfigurador das imagens (contra-)ditas.

É nesses termos que o tom do poema (uma “crônica” de eventos objetivos, como a guerra, o modo-de-produção capitalista, as práticas nazi-fascistas etc.) não diminui a importância literária dos recursos lingüísticos (desde que se perceba que as “referências” à conjuntura são profundamente mediadas pelo metalirismo).

125. Escuta o horrível emprego do dia

126. em todos os países de fala humana,

127. a falsificação das palavras pingando nos jornais,

128. o mundo irreal dos cartórios onde a propriedade é um bolo com flores,

129. os bancos triturando suavemente o pescoço do açúcar,

130. a constelação das formigas e usuários,

131. a má poesia, o mau romance,

132. os frágeis que se entregam à proteção do basilisco,

133. o homem feio, de mortal feiúra,

134. passeando de bote

135. num sinistro crepúsculo de sábado.

Nesses versos, a enumeração irônica (num tom lógico-discursivo) de aspectos fundamentais da organização social capitalista (cartórios, bancos, jornais, produção cultural) oculta, de fato, uma expressividade que está longe de apenas “referir-se”, de maneira imediata, a elementos "prosaicos”. Trata-se da figuração antropomórfica do tempo vivido (o "horrível emprego do dia”, reificado pela sua "metamorfose” em 
termos de "trabalho social abstrato"), a partir do verso 125, saturando todos os versos subseqüentes com imagens muito significativas. São elas: a redundância viciosa de "fala humana”, reduzida a sinestésicos “pingos” (que remontam ao famoso ditado anarquista: “Não leia jornais, minta sozinho”); a metáfora "bolo com flores”, que, no contexto do verso 128, transforma-se numa alegoria sarcástica de outro elemento estrutural do sistema capitalista: a "propriedade” (uma construção social que, no entanto, o fetiche da mercadoria, transposto para o plano da linguagem, busca "naturalizar", desistoricizando-a); a personificação do polissêmico “açúcar”, paradoxalmente despersonalizado pela lógica da usura (cuja metonímia é “banco”); a redução da escala humana ao micro-universo grotesco de “formigas” (num processo imagético panóptico, bastante empregado no livro de 1945, que figura a "metamorfose" do Gauche em “inseto"); a referência ao "lirismo deteriorado", que iguala dois gêneros literários (“poesia” e "romance”) na mesma categoria sintática, cujo qualificativo reitera, intensificando-a, a expressão adjetiva escarninha do verso 125 ("horrível emprego do dia”) e dos versos subseqüentes (“falsificação”, “mundo irreal” etc.); e, por fim, uma provável alusão (nos v. 133-135) ao romance A montanha mágica, de Thomas Mann²7 (cujo longo trecho citamos a seguir).

Com efeito, ele [Hans Castorp] sentia-se ocupado e absorto com o que havia no lugar onde estava. Se abrigava esperanças, tanto a sua realização como uma possível decepção aguardavam-no aqui e não numa Schatzalp qualquer. $O$ que o atormentava não era tédio; pelo contrário, começava a recear que o fim de sua estada chegasse com demasiada pressa. A segunda semana já estava avançada; dois terços do seu tempo em breve já teriam passado, e quando começasse o último terço, já seria tempo de arrumar as malas. Aquela primeira revitalização do senso de tempo de Hans Castorp havia muito que se passara; os dias já começavam a voar, e isso conquanto cada um deles se estirasse sob o efeito de uma expectativa sempre renovada e abundante de experiências silenciosas e secretas... Sim, o tempo é um enigma singular, difícil de resolver.

(...)

Não fazia ainda nem sequer duas semanas que Hans Castorp estava no [Sanatório Internacional de] Berghof, mas parecia-lhe muito mais tempo, e o programa do dia, ali em cima, esse programa que ele via Joachim [Ziemmsen,

\footnotetext{
227 Trata-se do "romance de formação", escrito nos anos seguintes à Primeira Guerra Mundial e publicado em 1924, e que tematiza em diversos níveis (inclusive no estilo) a problemática do "tempo" (veja-se "Excurso sobre o sentido do tempo", p. 141-146, em que a percepção temporal do protagonista Hans Castorp abandona de vez a dimensão "cronológica", que os internos do Sanatório Internacional de Berghoff identificam com a experiência "lá em baixo", e se familiariza, em definitivo, com a temporalidade d" "aqui de cima"). As citações que se seguem, entretanto, remetem a "Temor nascente. Dos dois avôs e do passeio de barca ao crepúsculo”, p. 194-220. Os trechos citados encontram-se, respectivamente, nas páginas: 194-195, 203-204, 205-206, 209-213, 219-220. (Os grifos são nossos.)
} 
seu primo] observar com tanto zelo piedoso, começava a adquirir a seus próprios olhos um quê de intangibilidade sagrada e natural, tanto assim que a vida lá de baixo, na baixada, vista assim de cima, se lhe afigurava quase anormal e errada. Já chegara a um alto grau de habilidade no manejo dos dois cobertores, mediante os quais a gente, nos dias frios, se transformava, por ocasião do repouso, num pacote simétrico, parecido com uma verdadeira múmia; pouco faltava para que igualasse a destreza de Joachim na arte de envolver-se segundo as regras; quase se admirava ao pensar que lá embaixo, na planície, ninguém sabia dessa arte. Pois é, isso era estranho, mas ao mesmo tempo Hans Castorp sentia estranheza diante do fato de que assim lhe parecia, $e$ novamente nascia nele o desassossego que o fazia perscrutar o seu íntimo em busca de um conselho ou de um apoio.

E ele pensou no dr. Behrens [diretor do Sanatório] e no seu conselho, oferecido sine pecunia, de viver exatamente como os pacientes e até de tomar a temperatura; lembrou-se também de Settembrini, que desatara a rir às gargalhadas ao ficar sabendo desse conselho, e depois citara qualquer coisa da Flauta mágica.

(...)

Mas havia ainda esse Settembrini, o oposicionista doidivanas e "Homo humanus", como se definia a si próprio, o homem que o censurara com abundantes palavras enfáticas, porque qualificara a combinação de estupidez e enfermidade, de contradição e de dilema para o sentimento humano. Que tal era ele? Era proveitoso ocupar-se com esse homem? Hans Castorp sabia ainda muito bem o quanto, em diversos daqueles sonhos excessivamente agitados que aqui em cima lhe enchiam as noites, exasperara-se por causa do sorriso fino e seco do italiano, que se esboçava sob a bonita curva do bigode; recordava-se de o ter tratado de tocador de realejo e de haver procurado afastá-lo do lugar, porque lhe parecia demais ali. Mas isso se passara num sonho, e Hans Castorp acordado era diferente, menos livre de inibições do que quando sonhava. Em estado de vigília, tudo isso podia ser de outro modo; talvez fizesse bem tentando conformar-se intimamente com essa maneira de ser, completamente nova para ele, que representava Settembrini; quem sabia se não eram dignas de ser estudadas sua rebeldia e sua crítica, posto fossem choramingueiras e gárrulas? O próprio Settembrini chamara-se de pedagogo. Evidentemente desejava exercer influência, e o jovem Hans Castorp anelava por alguém que o influenciasse. Naturalmente não era preciso levar a docilidade a ponto de se deixar induzir por Settembrini a arrumar as malas e a partir antes do tempo, conforme a sugestão que este lhe dera recentemente com toda a seriedade.

Placet experiri, pensou sorrindo: pois, para isso, sabia bastante latim, ainda que não se pudesse qualificar de Homo humanus. Assim, não perdia Settembrini de vista e escutava com gosto, embora com atenção crítica, tudo quanto o italiano produzia no decorrer das entrevistas que se realizavam ocasionalmente, durante os comedidos passeios prescritos pelo regime, até o banco na encosta da montanha ou até Davos-Platz. Havia também outras oportunidades para fazê-lo, quando Settembrini, após a refeição, era o primeiro a levantar-se e, com as suas calças xadrez e com um palito entre os dentes, atravessava indolentemente a sala a fim de fazer, em completo desacordo com o regulamento e os costumes, uma visitinha à mesa dos dois primos. Postava-se então diante deles, numa atitude graciosa, com os pés cruzados, e palestrava gesticulando com o palito. Ou talvez puxasse uma cadeira, para instalar-se num 
canto entre Hans Castorp e a professora, ou então entre o jovem e Miss Robinson, e para observar como os nove comensais comiam a sobremesa à qual ele mesmo parecia ter renunciado.

\section{(...)}

Settembrini falava de seu avô, que fora advogado em Milão, mas antes de tudo grande patriota, uma mistura de agitador público, orador e publicista. Também ele pertencera à oposição, tal qual o neto, mas praticara a coisa num estilo mais elevado, mais audacioso. Ao passo que Lodovico, como ele mesmo observava com amargura, via-se reduzido a escarnecer a vida e a condição do pessoal do Sanatório Internacional Berghof, a castigá-las com críticas zombeteiras e protestar contra elas em nome de uma humanidade bela e cheia de atividade, , dera o avô muito que fazer aos governos, conspirando contra a Áustria e a Santa Aliança, que naquela época haviam oprimido a sua despedaçada pátria, reduzindo-a a uma pesada servidão. Fora ele membro de certas sociedades secretas, difundidas na Itália - um carbonário, como explicou Settembrini, abaixando de repente a voz, como se ainda fosse perigoso falar dessas coisas. Numa palavra, segundo os relatos do neto, afigurava-se esse Giuseppe Settembrini aos dois ouvintes como um indivíduo sombrio, apaixonado, insurgente, um rebelde e um conjurado. Não obstante o respeito que os primos, por motivos de cortesia, procuravam sentir, não conseguiram apagar por completo nas suas feições uma expressão de antipatia desconfiada e até de repugnância. Verdade é que se tratava de um caso especial: o que ouviam, passara-se numa época remota, fazia quase cem anos, pertencia à história, e do ensino de história, sobretudo da antiga, era-lhes teoricamente familiar a mentalidade em apreço, o fenômeno do apego desesperado à liberdade e do ódio inflexível à tirania, se bem que nunca esperassem entrar em contato tão direto com esse espírito. Além disso houvera, como ficaram sabendo, na natureza revolucionária e conspiradora desse avô, um grande amor à pátria, que ele desejava ver livre e unida. Com efeito, a sua atividade sediciosa fora o fruto e a emanação desse sentimento respeitável, e por estranha que parecesse a cada um dos primos essa mistura de rebeldia e patriotismo - já que estavam acostumados a identificar o espírito patriótico com um senso de ordem conservador - , tinham de admitir, no seu íntimo, que sob as circunstâncias especiais daquela época e daquele país, podia ter havido identidade entre insurreição e dever cívico, de um lado, e do outro entre comedimento leal e indiferença preguiçosa, quanto à causa pública.

Mas o avô de Settembrini não fora somente um patriota italiano, senão também um concidadão e um irmão em armas de todos os povos sedentos de liberdade. Pois, após o malogro de certa tentativa de golpe de mão e de golpe de Estado, empreendida em Turim, e da qual ele participara com palavras e ações, escapando só por milagre dos esbirros do príncipe de Metternich, empregara seus anos de desterro a lutar e derramar seu sangue, ora na Espanha, em prol da constituição, ora na Grécia, para a independência do povo helênico. Ali é que ele chegara a ser um grande humanista e adorador da Antiguidade clássica. Nascera, aliás, de mãe de sangue alemão, pois Giuseppe casara-se com uma rapariga suíça e levara-a consigo em todas as suas andanças ulteriores. Mais tarde, depois de dez anos de exílio, pudera regressar à sua terra. Exercera em Milão a profissão de advogado, mas absolutamente não renunciara ao direito de concitar a nação pela palavra falada e escrita, em versos e em prosa, à liberdade e à instauração da república unida, de esboçar, 
com um brio passional e imperioso, programas revolucionários, e de proclamar, num estilo claro, a unificação dos povos libertados em prol da felicidade universal. Um pormenor mencionado por Settembrini, o neto, impressionou sobremaneira o jovem Hans Castorp: durante toda a sua vida, o avô Giuseppe mostrara-se aos seus compatriotas vestido de preto, alegando que usava luto pela Itália, sua pátria, que se definhava na miséria e na escravidão. Ao ouvir isso, Hans Castorp voltou a fazer uma comparação que já fizera diversas vezes mentalmente: lembrou-se de seu próprio avô, , que também, durante todo o tempo que o neto o conhecera, sempre usara roupas pretas, mas com um espírito totalmente diferente do que animara esse outro avô; recordou os trajes fora de moda, mediante os quais a natureza genuína de Hans Lorenz Castorp, aquela que pertencia a uma época remota, se adaptara ao presente, a título provisório e com acentuação da antipatia que os tempos modernos the inspiravam até o dia em que, no seu leito de morte, assumira solenemente a sua forma verdadeira e própria, com a golilha pregueada do tamanho de um prato $^{228}$. Havia deveras uma profunda diferença na maneira de ser dos dois avôs. Hans Castorp refletia sobre ela, enquanto o seu olhar se fixava no vazio, $e$ meneava a cabeça de uma forma cautelosa que tanto podia significar um sinal de admiração por Giuseppe Settembrini quanto uma manifestação de surpresa e desgosto. Por outro lado, esforçava-se por lealmente não condenar o que the parecia estranho, procurando não ir além da comparação e do exame dos fatos. Diante dele, na sala, surgia o rosto comprido do velho Hans Lorenz, que, pensativo, se inclinava sobre a concavidade redonda, levemente dourada, da bacia batismal, a relíquia da família na sua progressão imutável; e a boca do avô formara as sílabas "bis, tris, tetra", esses sons surdos e piedosos que evocavam a lembrança de lugares onde as pessoas avançam num andar reverente, cadenciado. E ao mesmo tempo via Hans Castorp como Giuseppe Settembrini, segurando a bandeira tricolor numa das mãos e brandindo um sabre na outra, erguia, num juramento sagrado, os olhos negros ao céu e se lançava à frente de um grupo de defensores da liberdade contra a falange do despotismo. Ambas essas atitudes tinham, sem dúvida, sua beleza e seu valor, pensava Hans Castorp, empenhando-se em ser justo, tanto mais que, pessoalmente, ou com parte do seu ser, se sentia um pouco parcial. Pois o avô de Settembrini combatera com o fim de obter direitos políticos, ao passo que a seu próprio avô ou, pelo menos, aos antepassados dele, haviam pertencido, originariamente, todos os direitos, e fora a canalha que lhos arrancara no decorrer de quatro séculos, por meio da violência e dos chavões... Eis que um e outro tinham andado vestidos de preto, o avô do norte e o do sul, cada qual com o objetivo de interpor uma rigorosa distância entre si mesmo e o malvado presente. Mas um agira assim por piedade, em homenagem ao passado e à morte, para os quais pendia a sua natureza; o outro, ao contrário, por rebeldia, a fim de honrar um progresso inimigo da piedade. "Certamente, isto são dois mundos, dois pontos cardeais", disse Hans Castorp de si para si, e, enquanto o sr. Settembrini prossequia contando, o jovem viu-se, por assim dizer, colocado entre eles, lançando olhares examinadores ora a um ora a outro. Parecia-lhe então que uma coisa semelhante já lhe ocorrera antes. Recordou um solitário passeio de barca, ao crepúsculo, num lago de Holstein, passeio que fizera em fins de verão, alquns anos atrás. Fora perto das sete horas; o Sol já se pusera

\footnotetext{
${ }^{228}$ O narrador faz menção ao "Segundo capítulo. Da pia batismal e dois aspectos do avô" (p. 30-42).
} 
e a Lua quase cheia já se elevara, a leste, por cima das margens do lago, cobertas de arbustos. $E$ durante dez minutos, enquanto Hans Castorp sulcava, remando, as áquas silenciosas, reinara uma constelação perturbadora, fantástica qual um sonho. Ao oeste resplandecera, como em pleno dia, uma luz vítrea, prosaica, decidida; mas bastara voltar a cabeca para deparar com uma paisagem de luar, iqualmente típica, entremeada de brumas úmidas $e$ cheia de máqico encanto. Esse contraste esquisito durara um quarto de hora, pouco mais ou menos, antes de se completar o triunfo da noite e da Lua. Com um pasmo alegre, os olhos deslumbrados e confundidos de Hans Castorp haviam passado de uma iluminação e de uma paisagem à outra, do dia para a noite e da noite para o dia. E nesse instante, ao comparar os dois avôs, não pôde deixar de se lembrar daquela impressão.

(...)

O jovem Hans Castorp achava tudo isso digno de ser escutado - sem compromisso e a título de experiência apenas, mas em todo caso digno de atenção. Foi nesse sentido que falou com Joachim Ziemssen, o qual, porém, por andar com o termômetro na boca, não podia responder senão indistintamente, $e$ que a seguir se mostrou por demais ocupado em decifrar os graus e inscrevê-los na papeleta, para que pudesse formular uma opinião acerca dos pontos de vista de Settembrini. Hans Castorp, porém, inteirava-se, cheio de boa vontade, dessas opiniões e abria-lhes o seu íntimo, a fim de estudá-las; o que deixa ver quanta vantagem leva o homem acordado sobre o homem que dorme estupidamente pois, nos seus sonhos, já acontecera diversas vezes a Hans Castorp tratar o sr. Settembrini, à queima-roupa, de tocador de realejo, e procurar empurrá-lo com toda a força, porque "era demais ali". Mas, como homem acordado, ouvia-o atenta e cortesmente e esforçava-se com muita imparcialidade por suavizar e diminuir a oposição que nele desejava levantar-se contra as idéias e as exposições do seu mentor. Não se pode negar que tal oposição existia na sua alma; também em outras, resultantes da situação presente, das experiências ora indiretas ora secretas que Hans Castorp fazia ali em cima.

Que é o homem, e com quanta facilidade pode ser ludibriada a sua consciência! Como é perito na arte de perceber na própria voz do dever a licença para se entregar à paixão! Era por um senso de dever, por eqüidade, pela necessidade de um contrapeso, que Hans Castorp escutava os discursos do sr. Settembrini, examinando, com muita complacência, as suas considerações quanto à razão, à república e à beleza do estilo, e dispondo-se a deixar-se influenciar por elas. Tanto mais lícito lhe parecia depois dar livre curso aos seus pensamentos e aos seus sonhos, a fim de que rumassem numa direção diferente e até oposta - e para formularmos desde já o resultado total do que suspeitamos ou adivinhamos, seja dito que escutava o sr. Settembrini com a finalidade exclusiva de obter da sua consciência plenos poderes que esta primitivamente não lhe quisera outorgar. Mas, que ou quem é que se encontrava do lado oposto ao patriotismo, à dignidade humana e às belas letras, desse lado onde Hans Castorp pensava ter reconquistado o direito de dirigir os seus pensamentos e seus atos? Ali se achava Clawdia Chauchat, indolente, carcomida, com seus olhos de quirquiz, e enquanto Hans refletia sobre ela - a palavra "refletir" é, aliás, muito mansa para expressar o modo como, no seu íntimo, se ocupava com ela -, era novamente como se andasse de barca por aquele lago de Holstein e diriqisse os olhos deslumbrados $e$ 


\section{confundidos pela luminosidade vítrea da margem ocidental, para a noite de luar, entremeada de brumas, dos céus do Oriente.}

A imagem do "passeio de bote [ou "barco"] ao crepúsculo", comum ao poema e ao romance, seria apenas de um hermetismo grotesco e intransitivo, em "Nosso tempo", caso não se identificasse o diálogo possível entre os dois textos ${ }^{229}$. Esse diálogo não elimina o significado intransitivo da imagem, na verdade o reforça, porque se trata de uma metáfora do impasse belicoso, tanto em Drummond quanto em Mann. Mas, para além da alusão imagética ao "impasse”, se estabelece um diálogo entre textos cujo sentido é a superação da intransitividade.

Pode-se afirmar que a imagem comum do "passeio de bote" não seja elemento suficiente de aproximação entre o poema e o romance, mas há outro indício de proximidade na mesma seção “Amar amaro". No primeiro poema da seção (“Coração numeroso”), o Gauche figura a si mesmo como "homem-realejo”, expressão semelhante àquela com a qual o protagonista, em A montanha mágica, designa o personagem Lodovico Settembrini.

8. Meus paralíticos sonhos desgosto de viver

9. (a vida para mim é vontade de morrer)

10. faziam de mim homem-realejo imperturbavelmente

11. na Galeria Cruzeiro quente quente

12. e como não conhecia ninguém a não ser o doce vento mineiro,

13. nenhuma vontade de beber, eu disse: Acabemos com isso.

Caberá, então, examinar, ainda que brevemente, em quais direções a aproximação entre o universo de significados d'A montanha mágica e o de "Nosso tempo" pode apontar. ${ }^{230}$

\footnotetext{
229 Diálogo entre textos que, de resto, ocorre em diversos outros poemas de $A$ rosa do povo, como "Nova canção do exílio". Vale lembrar que a imagem do "barco", usada também em outro poema da coletânea ("Equívoco"), faz-se presente nos textos fundadores da literatura ocidental: na Bíblia (associada ao Dilúvio e a Noé) e na Odisséia. Cf. Erich AUERBACH, Mimesis, p. 1-20.

230 CANÇADO (in Os sapatos de Orfeu, p. 179-181, grifos do autor) afirma: "Claro que esse clima de opinião trazia junto todas virtudes e todos os problemas da circunstância soviética naquele momento, incluída aí a influência do realismo socialista na cultura. Drummond, é preciso dizer, não escapou deles. Não deixa de ser curioso e revelador a esse respeito o teor do artigo que ele escreveu no início de 1943, e foi publicado em abril na revista Leitura. O Artigo é sobre $A$ montanha mágica, de Thomas Mann. O romance tinhas saído naqueles dias no Brasil, numa edição da Editora Pan-Americana, com tradução de Otto Silveira (só depois viria a tradução hoje conhecida de Herbert Caro).

É estranho ver Drummond lamentar e deplorar aquilo que o romance de Thomas Mann tem de insuperável: o fato de ser a maior e mais abrangente 'nosografia do nosso tempo'. (...)

O tom do artigo, e essa espécie de sugestão no sentido de que seriam mais benvindos, ao invés do enfermiço e enfumaçado Hans Castorp, um 'herói positivo' e um 'romance de resultados', são curiosos. Mais ainda é o que se depreende de uma passagem lá pelo meio do artigo quando Drummond lamenta que Thomas Mann não é um 'materialista', acrescentando que 'um materialista faria um romance exato de trezentas páginas, relato saudável de situações doentias'.”
} 
Na edição de A montanha mágica que consultamos, há um texto introdutório, sem autoria identificada, que afirma:

Escrito nos anos seguintes à Primeira Guerra Mundial, este romance é o mais completo painel de uma Europa enferma, à procura de uma unidade, de uma síntese espiritual e social, que seu próprio progresso tornou cada vez mais distante e inalcançável.

A ação transcorre na aldeia suíça de Davos-Platz, no sanatório Berghof. Aí se vêem reunidos pela doença elementos de toda as raças e credos humanos. Aí se entrelaçam problemas, inquietações, sofrimentos, ilusões dos mais diversos matizes psicológicos. Aí, ainda que isolados do mundo da "planície”, os personagens, conscientemente ou não, padecem a influência dos acontecimentos de um continente dilacerado. ${ }^{231}$

Hans Castorp, o herói, chega a Berghof em visita a seu primo. Ao seguir o conselho médico de que nada perderia se passasse alguns dias cumprindo o mesmo regime de vida dos internos, descobre, quase por acaso, que também está doente. Inicia-se, assim, seu período de adaptação. A vida no sanatório obedece a uma monotonia rígida, e o temperamento, já de natureza passiva, de Castorp encontra terreno fértil para expandir-se. Ele entra em contato com diferentes personalidades, dedica-se ao exame das idéias de cada uma delas, ao mesmo tempo que se põe a aprofundar os grandes temas da fé, da morte, da ciência, da filosofia, do amor e do tempo. ${ }^{232}$

À evolução da doença passa a corresponder o desenvolvimento humano de Castorp. À medida que aquela se instala em seu organismo, Castorp vai perdendo a característica de um jovem burguês encerrado nos hábitos e costumes de sua classe $^{233}$. Assume, então, uma postura intelectual em que se debatem as questões fundamentais feitas por todo homem que se interroga diante da vida.

A montanha mágica é, na verdade, o mais completo retrato de uma vida à procura de um sentido que a explique e justifique. Nada existe em si e por si mesmo; o mínimo gesto individual se conjuga a uma infinidade de ações e reações cuja exata medida é o próprio universo humano que o motiva, o recebe e o transforma. A salvação do homem se dá quando, mesmo (ou sobretudo) frente ao poder da morte, todos os seus atos se condicionam à busca da liberdade.

É desse mesmo prisma integrativo e "humanista” que A rosa do povo se coloca, muito embora sejam específicas a sua poética, a sua problemática e a conjuntura a que

\footnotetext{
231 Há que se notar a ironia involuntária existente nos encontros que, atualmente, acontecem em Davos, denominados Fórum Econômico Mundial. Nesses encontros anuais, representantes dos interesses capitalistas, governamentais ou privados, mais do que se debruçar sobre uma pauta de questões ligadas à economia capitalista mundial, fazem reforçar o poderio simbólico do capital, mediante o discurso midiático.

232 Cabe notar que o tema da "política é igualmente fundamental à trama narrativa, e à construção identitária de Hans Castorp.

233 A sua condição objetiva talvez se possa definir como "burguesa", mas a sua identidade subjetiva remete a origens aristocráticas. Este aspecto de Hans Castorp não é acessório, mas central, na trama do romance.
} 
explicitamente procura remeter. A rosa do povo também é uma obra de síntese, muito embora o seu aspecto imediato seja analítico, ou fragmentário. A sua dimensão política, que é fundamental, não exclui (antes pressupõe) as dimensões da subjetividade, porque se faz como síntese de elementos múltiplos, e freqüentemente contraditórios. A política não é o centro exato do lirismo (ou do "gauchismo") em A rosa do povo, mesmo porque nele não há um único centro (sendo o próprio personagem Gauche um “excêntrico”234). As questões do indivíduo figuram-se tão importantes quanto as questões do mundo (a existência politiza-se, e, com a mesma importância, a política subjetiva-se).

Uma grande diferença entre o romance e a coletânea remete à questão do engajamento. Tanto Drummond quanto Thomas Mann denunciam os pressupostos totalitários do belicismo nazi-fascista (que se gesta nos anos 1920 e esfacela-se na década de 1940), mas Drummond (através do recurso ao gauchismo) parece tomar partido do marxismo-leninismo, enquanto, em Thomas Mann, o plano autoral não enuncia a adesão militante a nenhum referencial objetivo, limitando-se a figurar, criticamente, as correntes ideológicas e políticas do pré-guerra, e, sobretudo, as contradições do irracionalismo belicista.

Drummond também lastima o belicismo, mas não se abstém de interpretar os sentidos das suas contradições em termos precisos (atribuindo-as à "marcha do mundo capitalista”), nem de aderir à Resistência (aproximando-a do socialismo soviético). Mas é fundamental situar essa dimensão militante (biográfica) no devido contexto bibliográfico, cujo plano significante (estético) não comporta o mero adesismo (sendo, ao contrário, implacável com a sua própria auto-imagem, através do metalirismo). Em outras palavras, convém separar a dimensão autoral da dimensão lírica, as quais interrelacionam-se, sem, contudo, confundir-se. ${ }^{235}$

De uma forma autocrítica, a dimensão lírica não cai num relativismo que a tudo justificaria, mas também não reivindica para o seu olhar um caráter absoluto. Assim é que se compreende que o sentido da guerra, para Drummond, seja a agudização das contradições capitalistas, expressas pelo belicismo nazi-fascista, o que portanto o leva a tomar partido contra o capital. Contudo, não se trata de uma identificação irrestrita com

\footnotetext{
234 SANT'ANNA, op. cit.

235 Essa complexidade, tanto no plano da biografia quanto no plano da bibliografia (intercambiáveis, mas não imediatamente reversíveis), explica porque Drummond, tendo realizado uma grande conquista em termos de literatura participante no Brasil (segundo Antonio CANDIDO, "Inquietudes na poesia de Drummond", op. cit., p. 125), não tenha se adaptado ao pragmatismo coletivista (em prejuízo dos aspectos da subjetividade) do Partido Comunista do Brasil, em especial quando da sua participação no periódico Tribuna Popular (cf. CANÇADO, op. cit., p. 139-239, e Carlos DRUMMOND DE ANDRADE, O observador no escritório, p. 19-53 e, em especial, as anotações no dia 12 de abril, p. 31).
} 
o ideário socialista soviético, à medida que a poética drummondiana não abre mão de criticar importantes pressupostos dogmáticos daquele ideário, como por exemplo o sacrifício da individualidade em razão das questões "maiores", ou mais "prementes”, da coletividade, expressas pelo Partido ou por qualquer outro ente hierárquico, ou então o dogma de que a revolução proletária levaria à extinção das contradições sociais ${ }^{236}$.

A poética drummondiana configura um pensamento que integra alguns "temas” caros ao seu lirismo gauche (como a luta contra o nazi-fascismo, a despersonalização no cotidiano reificado do capitalismo industrial, a identidade pessoal e familiar etc.). Mas, para além dessa "temática”, há uma visão de mundo mais ampla, que se identifica com a poética de Thomas Mann.

N’A montanha mágica, como permite entrever a introdução que citamos, estão representadas, com muita agudeza, as principais questões do pensamento na passagem do século XIX para o XX (filosóficas, científicas, políticas, estéticas etc.), que se imbricam, de certo modo, na gênese do conflito mundial. Mas, para além desse nível de refinada erudição, há um princípio artístico integrativo, que faz com que essas idéias se confrontem, de tal maneira, que terminam por confundir-se, tornando-se explícitas as suas contradições. Mais que isso, o autor alcança um elevado grau de verossimilhança psicológica, ao compor personagens tão visceralmente identificados com determinados ideários que, em sua defesa, travam violentos embates com personagens antípodas, chegando ao limite da agressão física e moral.

Entre todos os personagens, Lodovico Settembrini (o "tocador de realejo" a que “Coração numeroso” faz menção), e Leo Naphta (o judeu espanhol, convertido ao catolicismo pela Companhia de Jesus na Alemanha) protagonizam o embate de maior alcance dramático do romance. Antípodas inconciliáveis, têm em comum apenas o intuito “pedagógico” de arrebatar a mente do jovem Hans Castorp, e nos infindáveis duelos que travam diante do rapaz (em defesa do ideário iluminista ou, então, da ascese católica), invariavelmente proporcionam o espetáculo cômico de contradizerem os seus

\footnotetext{
${ }^{236}$ Vejam-se, nesse sentido, os versos de "O mito":

169. E colocamos os dados

170. de um mundo sem classe e imposto;

171. e nesse mundo instalamos

172. os nossos irmãos vingados.

173. E nessa fase gloriosa,

174. de contradiçoes extintas,

175. eu e Fulana, abrasados,

176. queremos... que mais queremos?
} 
próprios princípios ou idéias, ou então de aproximarem-se da perspectiva do oponente, sem, contudo, admiti-lo.

Esse princípio dialético que anima o livro, e que se efetiva tanto em termos conceituais como em termos estilísticos, converge para a construção do personagem principal, que é o jovem Hans Castorp. Ao romper, ao longo do livro, todos os vínculos com o seu cotidiano hamburguês, o jovem passa a conviver com questões das mais variadas naturezas, dum ponto de vista que o próprio Castorp designa como "regência". “Reger”, para o rapaz, significa confrontar pontos de vista contrários sobre determinado problema, sem, necessariamente, visar à sua resolução ou à tomada de partido.

A sua postura contemplativa diante dos conflitos, que aparentemente prepara uma maturidade intelectual (mas que, no fundo, o incapacita para a vida), termina, entretanto, tragicamente, seja com o progresso da sua infecção pulmonar, seja com o andamento dos conflitos imperiais, ou, então, com o desfecho trágico do embate entre Settembrini e Naphta (estes três planos da trama entrecruzam-se). De qualquer modo, a contemplação dá lugar à participação inevitável nos desdobramentos da vida na “planície”, paradoxalmente mortíferos. Castorp abandona a atitude contemplativa da “montanha” para engajar-se na "lama” das trincheiras.

Os diversos conflitos que se engendram na temporalidade rarefeita dos "ares da montanha” acabam revelando, na trama narrativa, uma proximidade incontornável com a "planície", na medida em que todos os homens do "Sanatório Internacional”, em que pesem as suas idiossincrasias, carregam em si o germe da morte, que os nivela, a despeito de todas as expectativas quanto à vida e às contradições “lá em baixo”. O romance, então, enxerga os conflitos com um distanciamento de mão dupla, suficiente para denunciar tanto a estupidez do morticínio na "planície” como também a condição mortal na "montanha".

Ao seu modo, é esse jogo de perspectivas que a complexidade do lirismo drummondiano também logra alcançar. Sob a(s) persona(e) do Gauche, figuram-se diversos aspectos da temporalidade vivida, integrando-se as questões mais imediatamente conjunturais a uma visão temporalmente mais profunda da condição finita do homem, cujo efeito, apenas aparentemente paradoxal, é a valorização do “tempo presente" e do "sentimento do mundo", considerando o indivíduo e o vivido como escala. Tanto a perspectiva “montanhesa” quanto a perspectiva “inferior” da “condição humana” entrelaçam-se, e, assim, se faz superar a atitude contemplativa do “personagem” entre ideários que, ao contraporem-se, estão na verdade a revelar as suas 
próprias contradições, contaminados pelo “finito” e pela "matéria”237, sem, entretanto, resignarem-se ao impasse.

Em síntese, pode-se dizer que, em “Nosso tempo", a percepção de uma temporalidade cotidiana reificada não exclui, porque pressupõe, outras perspectivas temporais. Isso, no plano do estilo, implica a figuração do impasse pelo recurso à transfiguração ${ }^{238}$.

Nesses termos, a figuração de um cotidiano tripartido é literariamente eficaz, porque, se de um lado implica a experiência lingüística (simultaneamente cognitiva e afetivo-sensorial) do tempo social abstrato (a reificação capitalista), de outro o faz com um distanciamento, cujo resultado é revelar o absurdo do costumeiro, historicamente situado, sem, contudo, prescindir da escala do vivido.

O vivido se vê contaminado pelo totalitarismo panóptico:

74. É tempo de meio silêncio,

75. de boca gelada e murmúrio,

76. palavra indireta, aviso

77. na esquina. Tempo de cinco sentidos

78. num só. $O$ espião janta conosco.

79. É tempo de cortinas pardas,

80. de céu neutro, política

81. na maçã, no santo, no gozo,

82. amor e desamor, cólera

83. branda, gim com água tônica,

84. olhos pintados,

85. dentes de vidro,

86. grotesca língua torcida.

87. A isso chamamos: balanço.

88. No beco,

89. apenas um muro,

90. sobre ele a polícia.

91. No céu da propaganda

237 Menção ao v. 31 de "Consideração do poema".

238 Vimos, entre outros recursos, o diálogo entre textos, enunciado explicitamente em "Consideração do poema", desdobrado metalingüisticamente em "Procura da poesia" e praticado em "Nosso tempo". 
92.

aves anunciam

93. a glória.

94. No quarto,

95. irrisão e três colarinhos sujos.

A lógica do domínio político, em seu afã de controle totalitário, imprime o ethos do medo aos aspectos mais íntimos da vida diária. O espaço figurado é doméstico, como se pode notar. Talvez, o "santo” em que a "política” se infiltra seja aquele do "Edifício São Borja”. E, em função do “meio silêncio”, é difícil compreender a que, exatamente, se refere o conjunto desconexo dos v. 79-87, cuja "precária síntese” ensaia-se na denominação "balanço" (talvez seja a "marcha" do american way of life sob a “modernização conservadora”, a mesma que organiza a “implacável guerra às baratas”, nos v. 143-144). De todo modo, o ritmo "grotescamente" sincopado, que se percebe nestes e em outros versos (como a ilustrar que “é tempo de muletas”: v. 48), certamente sofre a operação mutiladora dos "laboratórios platônicos mobilizados” (v. 37), dentre os quais a “propaganda” (em sua lógica “publicitária”) ganha um destaque especial ${ }^{239}$. Como produto integrante da separação político-publicitária entre significante / significado, encontra-se a "grotesca língua torcida”, a um tempo, índice de “modernidade” e de "meio silêncio".240

As quatro estrofes subseqüentes aos versos 74-95 (que enunciaram em “cifras” a politização da intimidade) figurarão com excepcional lucidez a abstrata "marcha do mundo capitalista” (v. 177) em direção à experiência cotidiana. Será necessário citá-las integralmente, mas, desde já, note-se que a sua perspectiva é também panóptica. ${ }^{241}$

\footnotetext{
239 Vejam-se os trechos de "Nosso tempo":

35. Simbolos obscuros se multiplicam.

36. Guerra, verdade, flores?

37. Dos laboratórios platônicos mobilizados

38. vem um sopro que cresta as faces

39. e dissipa, na praia, as palavras.

88. $\quad$ No beco,

89. apenas um muro,

90. sobre ele a policia.

91. No céu da propaganda

92. aves anunciam

93. a glória.

94. No quarto,

95. irrisão e três colarinhos sujos.

240 É possível identificar, como referente externo a estes versos, o Departamento de Imprensa e Propaganda (DIP), cujas funções comportavam a censura, a repressão policial e a veiculação de programas audiovisuais que exultassem os feitos do governo Vargas, promovendo, com estes fins, a politização de aspectos da vida privada.

241 Às práticas quantificantes do poder institucional (a "perspectiva panóptica"), é possível contrapor e verificar práticas qualificantes de um micropoder. "Em Vigiar e Punir, Michel Foucault substitui a análise dos
} 
96. Escuta a hora formidável do almoço

97. na cidade. Os escritórios, num passe, esvaziam-se.

98. As bocas sugam um rio de carne, legumes e tortas vitaminosas.

99. Salta depressa do mar a bandeja de peixes argênteos!

100. Os subterrâneos da fome choram caldo de sopa,

101. olhos líquidos de cão através do vidro devoram teu osso.

102. Come, braço mecânico, alimenta-te, mão de papel, é tempo de comida,

103. mais tarde será o de amor.

104. Lentamente os escritórios se recuperam, e os negócios, forma indecisa, evoluem.

105. O esplêndido negócio insinua-se no tráfego.

106. Multidões que o cruzam não vêem. É sem cor e sem cheiro.

107. Está dissimulado no bonde, por trás da brisa do sul,

108. vem na areia, no telefone, na batalha de aviões,

109. toma conta de tua alma e dela extrai uma porcentagem.

110. Escuta a hora espandongada da volta.

111. Homem depois de homem, mulher, criança, homem,

112. roupa, cigarro, chapéu, roupa, roupa, roupa,

113. homem, homem, mulher, homem, mulher, roupa, homem

114. imaginam esperar qualquer coisa,

115. e se quedam mudos, escoam-se passo a passo, sentam-se,

116. últimos servos do negócio, imaginam voltar para casa,

117. já noite, entre muros apagados, numa suposta cidade, imaginam.

118. Escuta a pequena hora noturna de compensação, leituras, apelo ao cassino,

119. o corpo ao lado do corpo, afinal distendido, [passeio na praia,

120. com as calças despido o incômodo pensamento de escravo,

121. escuta o corpo ranger, enlaçar, refluir,

122. errar em objetos remotos e, sob eles soterrado sem dor,

123. confiar-se ao que-bem-me-importa

124. do sono.

Numa visão panorâmica, que se faz a partir do ponto de vista absolutizante do “negócio” (a desconsiderar outras racionalidades que não a do lucro), figura-se o tempo

aparelhos que exercem o poder (isto é, das instituições localizáveis, expansionistas, repressivas e legais) pela dos 'dispositivos' que 'vampirizaram' as instituições e reorganizaram clandestinamente o funcionamento do poder: procedimentos técnicos 'minúsculos', atuando sobre e com os detalhes, redistribuíram o espaço para transformá-lo no operador de uma 'vigilância' generalizada. Problemática bem nova. No entanto mais uma vez, esta 'microfísica do poder' privilegia o aparelho produtor (da disciplina), ainda que, na 'educação', ela ponha em evidência o sistema de uma 'repressão' e mostre como, por trás dos bastidores, tecnologias mudas determinam ou curto-circuitam as encenações institucionais. Se é verdade que por toda a parte se estende e se precisa a rede da 'vigilância', mais urgente ainda é descobrir como é que uma sociedade inteira não se reduz a ela: que procedimentos populares (também 'minúsculos' e cotidianos) jogam com os mecanismo da disciplina e não se conformam com ela a não ser para alterá-los; enfim, que 'maneiras de fazer' formam a contrapartida, do lado dos consumidores (ou 'dominados'?), dos processos mudos que organizam a ordenação sóciopolítica.” (in Michel de CERTEAU, A invenção do cotidiano. Artes de fazer, p. 41). 
social do trabalho, tripartido em "tempo forçado", “tempo obrigado” e "tempo livre”. O “tempo forçado" é aquele em que a força de trabalho se reproduz, atendendo às necessidades de alimentação, vestuário, habitação, entre outras. O “tempo obrigado” é aquele em que o trabalho produtivo se faz. No sistema da propriedade privada dos meios de produção, com vistas ao lucro e ao seu reinvestimento, ele significa um contrato entre os donos do capital e os que nada têm, a não ser a própria força de trabalho, alugada ao capitalista em troca de um salário, o que torna legítimo a apropriação, pelo capitalista, de toda a produtividade, exceto o estritamente necessário para a reprodução da mão-de-obra e, portanto, da produção da mais-valia. Por fim, o “tempo livre”, cujo princípio é o ócio, e que assume a forma, não mais da necessidade, mas da gratuidade, não chega a negar os dois momentos anteriores, sendo antes o seu reverso. $^{242}$

Por sob uma aparente descrição do "horrível emprego do dia” (v. 125), o que se vê é o estranhamento do cotidiano industrial. Uma das características da temporalidade cotidiana é o hábito, o ato automático, que se produz com um mínimo gasto energético, reflexivo inclusive. $^{243}$ Por outro lado, isso não implica que o cotidiano seja necessariamente a temporalidade em que não cabe a ressignificação dos múltiplos aspectos da experiência pessoal; ao contrário, a impossibilidade de ressignificá-los cotidianamente é uma característica histórica do capitalismo, que, entretanto, procura a naturalização do seu ethos fragmentário através da ideologia.

A razão de intensificar-se a divisão social do trabalho não é, somente, o aumento da produtividade, mas, sobretudo, a sua justificativa ideológica, decorrente da separação simbólica entre o sentido da produção e o seu ato concreto, de tal modo que o “trabalho” passa a ser percebido como algo abstrato, segundo mecanismos conceituais que afetam, inclusive, a linguagem, e que tornam legítimo tratá-lo como mercadoria (quando, ao contrário, o seu sentido é a satisfação das necessidades subjetivas mediante a transformação da natureza em cultura, o que o caracteriza como um dos fundamentos do psiquismo humano). O trabalho, tornado abstrato pela reificação mercantil, perde o seu sentido integrativo, uma vez que o seu significado (distorcido pela lógica abstrata da mais-valia) aparta-se do seu ato concreto (o gesto cotidiano do trabalho) e do seu sujeito de fato (a pessoa do trabalhador). ${ }^{244}$

\footnotetext{
${ }^{242}$ A definição do tempo tripartite remete a Henri LEFEBVRE, La vida cotidiana en el mundo moderno, p. 62-79. 243 Agnes HELLER, O cotidiano e a história, p. 17-41.

244 Idem, ibidem, p. 87-110.
} 
O resultado dessa separação ideológica entre as dimensões significativas do trabalho (significante / significado) é o aprofundamento da especialização produtiva e da extração de mais-valia. Para tanto, é preciso que o trabalho perca a sua dimensão concreta e integral, e seja visto como algo apartado do trabalhador (uma mercadoria, como tantas outras, cujo valor se estabelece pela "lei” da oferta e da procura). A lógica da produção do lucro pela intensificação do trabalho especializado é um dos sentidos fundamentais da tripartição do tempo ${ }^{245}$. Dessa maneira, o “esplêndido negócio” (nunca nomeado, sempre “insinuado”, em “cifras”), “toma conta de tua alma e dela extrai uma porcentagem”, ainda que, para isso, seja necessário “escravizar” (isto é, transformar em mercadoria, desprovida portanto de direitos e de autonomia) a integridade subjetiva dos “últimos servos do negócio".

O estraçalhamento das subjetividades “espandongadas” é algo ao mesmo tempo muito abstrato (o "trabalho social”) e suficientemente concreto (o "tempo social”, “nosso”), o que torna difícil nomeá-lo: trata-se de um “negócio” (ainda assim, é plenamente possível intuir a sua lógica na experiência diária, comum). De todo modo, não sendo possível figurar o cotidiano como uma experiência integral, não surpreende que a subjetividade lírica recorra ao gauchismo.

Por sob a visada panóptica, a descrever o "horrível emprego do dia” duma perspectiva muito próxima às da estatística e da macropolítica (para quem as especificidades subjetivas não contam, e sim os comportamentos que se podem prever e controlar ${ }^{246}$ ), o eu lírico desdobra-se num “tu”, a quem dramaticamente, recomenda-se: “come, braço mecânico, alimenta-te, mão de papel, é tempo de comida, / mais tarde será o de amor." É também ao "tu” que se dirigem “olhos líquidos de cão através do vidro [que] devoram teu osso.” Da perspectiva totalitária, panorâmica, o “esplêndido negócio”, “dissimulado no bonde, por trás da brisa do sul, / vem na areia, no telefone, na batalha de aviões, / toma conta da tua alma e dela extrai uma porcentagem.”.

Entretanto, depois de minuciosamente decifradas as "horas de comer, trabalhar, divertir-se, amar e dormir” sob a perspectiva do “negócio”, o eu lírico, embora ainda dirija-se ao "tu”, reduz a sua experiência à do “corpo" (objetivado como uma "terceira

\footnotetext{
245 Henri LEFEBVRE, op. cit., p. 62-79.

246 "Escapando às totalizações imaginárias do olhar, existe uma estranheza do cotidiano que não vem à superfície, ou cuja superfície é somente um limite avançado, um limite que se destaca sobre o visível. Neste conjunto, eu gostaria de detectar práticas estranhas ao espaço 'geométrico' ou 'geográfico' das construções visuais, panópticas ou teóricas. Essas práticas do espaço remetem a uma forma específica de 'operações' ('maneiras de fazer'), a 'uma outra espacialidade' (uma experiência 'antropológica', poética e mítica do espaço) e a uma mobilidade opaca e cega da cidade habitada. Uma cidade transumante, ou metafórica, insinua-se assim no texto claro da cidade planejada e visível." (in Michel de CERTEAU, op. cit., p. 171-172).
} 
pessoa”), a "ranger, enlaçar, refluir, / errar em objetos remotos e, sob eles soterrado sem dor, / confiar-se ao que bem-me-importa / do sono.”. Sob todas as máscaras do processo de despersonalização, que recorre inclusive à perspectiva totalitária do “negócio”, a escala, contudo, permanece a do lirismo.

Em todas as oito seções do poema, a "face trocista” (v. 171) do “poeta” (v. 175) é(são) a(s) mesma(s) que, ao longo de todo A rosa do povo, envolve(m)-se com o mundo por meio da cifra, da nomeação e / ou da catarse, identificando-se com os eventos, ou, quando traumáticos, refugiando-se no seu universo subjetivo (ou, ainda, recorrendo a dimensões pretéritas, como forma de, ao construir memórias, lidar com as experiências contemporâneas reificantes). O sentido dessa experiência rigorosamente pessoal, cujo “(res)sentimento do mundo” visa a redimir-se e redimi-lo pela completude (mas que, invariavelmente, termina por constatar o impasse), é o enfrentamento da despersonalização, tomando partido do indivíduo e da dimensão cotidiana do vivido, contra o monumental e o panóptico.

Em "Nosso tempo", o embate entre a temporalidade do "negócio" e a temporalidade lírica do indivíduo, embora produza destroços, encaminha-se para a sua superação, assumindo um caráter de síntese, por sob a desfiguração analítica. Se, na seção “Amar amaro” da Antologia poética, o poema é central, em A rosa do povo essa centralidade, embora mais sutil, não é menos importante.

Ao figurar o sem-sentido do “mundo capitalista” referindo-se à guerra, aos governos totalitários e ao dia-a-dia urbano-industrial, a subjetividade lírica do Gauche não se restringe à mimese, nem, tampouco, aos eventos objetivos. O Gauche percorre 0 espaço exterior como forma de dar vazão à sua interioridade e, assim, refazer-se. Se o desejo de completude invariavelmente frustra-se na exterioridade do real fragmentário, isso tampouco o leva a exilar-se permanentemente na sua subjetividade. O trânsito permanente do real objetivo ao real subjetivo requer a permanente figuração do “canto”, como elemento mediador entre as necessidades líricas e as vicissitudes objetivas. Esse dinamismo, que se encontra por completo em “Nosso tempo”, é também o dinamismo de todo A rosa do povo. 
Na coletânea, é impossível encontrar momentos exclusivamente direcionados à subjetividade lírica ou à objetividade conjuntural. Poemas como "Vida menor", apesar de figurar a interioridade subjetiva, imbricam-se com o absurdo do real objetivo, traumático; são, de uma forma ou de outra, expressões do inominável. Por outro lado, poemas como “Carta a Stalingrado” apresentam a marca indelével da subjetividade lírica, da sua perspectiva restrita, interdita. Em comum, além do desejo de redenção, consciente da sua precariedade, os poemas apresentam a figuração metalingüística do “canto” como elemento mediador, cuja escala é a da experiência lírica (individual portanto) no tempo vivido.

O morticínio, resultante da "marcha do mundo capitalista” ("Nosso tempo”, v. 176), torna a figurar-se em diversos outros poemas da coletânea, como é evidente na lírica de guerra. Que a “guerra” é um desdobramento do “negócio”, não há dúvida:

104. Lentamente os escritórios se recuperam, e os negócios, forma indecisa, evoluem. 105. O esplêndido negócio insinua-se no tráfego.

106. Multidões que o cruzam não vêem. É sem cor e sem cheiro.

107. Está dissimulado no bonde, por trás da brisa do sul,

108. vem na areia, no telefone, na batalha de aviões,

109. toma conta de tua alma e dela extrai uma porcentagem. ${ }^{247}$

Mas a "guerra” faz parte de um amplo espectro de conseqüências, todas nefastas, do “negócio”, cujo ethos, como vimos, é o “medo”, e cuja expressão (em cifras ou direta) é o "meio silêncio",248.

No poema "O medo", dedicado a Antonio Candido, o sentimento também se figura como princípio:

1. $\quad$ Em verdade temos medo.

2. $\quad$ Nascemos escuro.

3. As existências são poucas:

4. carteiro, ditador, soldado.

5. Nosso destino, incompleto.

6. $\quad$ E fomos educados para o medo.

7. Cheiramos flores de medo.

8. Vestimos panos de medo.

9. De medo, vermelhos rios

10. vadeamos.

247 Versos do poema "Nosso tempo".

248 Menção ao v. 74 de "Nosso tempo". 
23. Fiquei com medo de ti,

24. meu companheiro moreno.

25. De nós, de vós; e de tudo.

26. Estou com medo da honra.

27. Assim nos criam burgueses.

28. Nosso caminho: traçado.

29. Por que morrer em conjunto?

30. E se todos nós vivêssemos?

O medo, princípio, associal por natureza, da propriedade privada, organiza o espaço e infiltra-se na dimensão da subjetividade:

31. Vem, harmonia do medo,

32. vem, ó terror das estradas,

33. susto na noite, receio

34. de águas poluídas. Muletas

35. do homem só. Ajudai-nos,

36. lentos poderes do láudano.

37. Até a canção medrosa

38. se parte, se transe e cala-se.

39. Faremos casas de medo,

40. duros tijolos de medo,

41. medrosos caules, repuxos,

42. ruas só de medo e calma.

43. E com asas de prudência,

44. com resplendores covardes,

45. atingiremos o cimo

46. de nossa cauta subida.

47. O medo, com sua física,

48. tanto produz: carcereiros,

49. edifícios, escritores,

50. este poema; outras vidas.

A organização do espaço objetivo, de fato, segue o princípio do medo nos planos arquitetônico, urbanístico e, mesmo, textual (porque a "canção medrosa / se parte, se transe e cala-se.”). ${ }^{249}$ Verdadeiro paradoxo dum sistema sócio-econômico, que se

249 Note-se que a escalada da fragmentação intransitiva se aplica não apenas àquele contexto da urbanização industrial, mas também ao contexto pós-industrial do mundo "globalizado", vejam-se, atualmente, os 
assenta na livre circulação de informações e de mercadorias em caráter exponencial, o espaço ampliado segundo a escala do medo é, também, o espaço interdito a outras relações que não as mercantis.

35. Adeus: vamos para a frente,

36. recuando de olhos acesos.

37. Nossos filhos tão felizes...

38. Fiéis herdeiros do medo,

39. eles povoam a cidade.

40. Depois da cidade, o mundo.

41. Depois do mundo, as estrelas,

42. dançando o baile do medo.

O que a “física do medo" "tanto produz” são, na verdade, papéis sociais e espaços subjetivamente empobrecidos, destinados ao utilitarismo e pré-concebidos. Neste mundo da certeza e da segurança, elimina-se o imprevisto do desejo através dos “caminhos: traçados”. Por isso, encontram-se interditas as identidades plurais, e por isso “as existências são poucas”. E, de fato, a retórica “medrosa” da "canção”, eivada de enjambements e truncamentos sintáticos (que desfiguram a sugestão de fluência e regularidade dos quartetos), bem como recheada de alusões e cifras, encontra razão de ser no contexto a que remete. Vejam-se os seguintes versos:

15. Refugiamo-nos no amor,

16. este célebre sentimento,

17. e o amor faltou: chovia,

18. ventava, fazia frio em São Paulo.

19. Fazia frio em São Paulo...

20. Nevava.

21. O medo, com sua capa,

22. nos dissimula e nos berça.

Em si, e no contexto do poema, essas duas quadras já encontram significado suficiente, ao criar uma experiência imagética para o princípio do medo. Mas o seu movimento significante não pára por aí, porque há, também, uma referência velada à resistência estudantil contra o governo ditatorial de Vargas, representada por Antonio Candido e por seus companheiros de universidade (cujos indícios já se encontram na

condomínios fechados e a "Cruzada contra o terrorismo". aspectos de diferentes contextos capitalistas aproximam-se porque o ethos intransitivo do medo é, de certa maneira, uma permanência. 
dedicatória e na epígrafe ${ }^{250}$ ), menção que, naquele momento, de fato, não se poderia enunciar explicitamente. ${ }^{251}$ Dessa forma, o poema, embora não se restrinja ao contexto imediato da modernização conservadora do governo ditatorial de Vargas, entretanto não se esquiva de referências objetivas a eventos cotidianos, e, com isso, a linguagem poética não se torna menos densa.

O medo, mais que um sentimento pessoal, é algo onipresente, mas percebê-lo como escala de todas as experiências, pessoais e interpessoais, e nomeá-lo poeticamente, requer um grau de intelecção que ultrapassa o nível intuitivo, mas que não deve fugir à escala poética do lirismo.

O poema “Anoitecer” é uma elegia do mundo urbano-industrial, também marcada pelo “medo”. Nele, vislumbra-se a tripartição do cotidiano contemporâneo pela perspectiva do indivíduo, sem que, no entanto, o lirismo alcance o grau de despersonalização que notamos em “Nosso tempo". ${ }^{252}$
1. É a hora em que o sino toca,
2. $\quad$ mas aqui não há sinos;
3. há somente buzinas,
4. $\quad$ sirenes roucas, apitos
5. aflitos, pungentes, trágicos,
6. uivando escuro segredo:
7. desta hora tenho medo.
8. É a hora em que o pássaro volta,
9. $\quad$ mas de há muito não há pássaros;
10. Só multidões compactas
11. escorrendo exaustas
12. como espesso óleo
13. que impregna o lajedo;

\footnotetext{
250 A epígrafe do poema ("Porque há para todos nós um problema sério... Este problema é o do medo.") é um trecho de "Plataforma da nova geração" (que Drummond cita, provavelmente de memória, como "Plataforma de uma geração"), artigo escrito por Antonio Candido, quando estudante universitário, na "revista de moços" Joaquim (p. 6). Reproduzimos, a seguir, todo o trecho final: "Relendo estas notas Mário Neme, vejo que acabei quase respondendo à sua pergunta que fica meio gaiata com o sotaque piracicabano. Não faz mal. É uma atitude pessoal, que às vezes me apraz considerar justa. Porque há para todos nós um problema sério, tão sério que nos leva às vezes a procurar meio afoitamente uma 'solução': a buscar uma regra de conduta, custe o que custar. Este problema é o do MÊDO. Do mêdo que nos toma a todos de estarmos sendo inferiores à nossa tarefa ou de não conseguirmos fazer algo de definitivamente útil para o nosso tempo, como, de um modo ou de outro, fizeram os rapazes de Vinte. Você tem algum critério para afastar êste mêdo? Eu não posso bem dizer que tenha mas confesso que êsse combate a tôdas as formas de Reação, que eu apenas sugeri, nos ajudaria muito a ficar livres dêle. E a podermos dormir em paz."

251 Cf. nota 142, no cap. 4.

252 José Miguel WISNICK musicou este poema de Drummond (cf. Pérolas aos poucos, faixa 6), com uma compreensão muito aguda da sua integridade lírica (expressa na linha melódica), em contraste com o truncamento rítmico (expresso por síncopes que dilatam ou contraem os compassos). Os timbres agudos da percussão, a mimetizar as sonoridades de "sinos", reforçam esse jogo entre uma subjetividade dilacerada e um mundo fragmentado.
} 
14. desta hora tenho medo.

15. É a hora do descanso,

16. mas o descanso vem tarde,

17. o corpo não pede sono,

18. depois de tanto rodar;

19. pede paz - morte - mergulho

20. no poço mais ermo e quedo;

21. desta hora tenho medo.

22. Hora de delicadeza,

23. gasalho, sombra, silêncio.

24. Haverá disso no mundo?

25. É antes a hora dos corvos,

26. bicando em mim, meu passado,

27. meu futuro, meu degredo;

28. desta hora, sim, tenho medo.

A “sinos”, equivalem "pássaros”, “descanso”, “delicadeza, gasalho, sombra, silêncio” como características de uma temporalidade pré-industrial, ainda viva na sensibilidade lírica, mas não identificada no espaço-tempo da urbanização industrial. ${ }^{253}$ No lugar daqueles antigos símbolos, há “ruídos” significantes, que não correspondem a significados no plano da experiência lírica, cuja sensibilidade recria para si um ritmo, não mais cíclico, mas repetitivo: o do trauma (expresso pela estrutura anafórica de “desta hora tenho medo”, que significativamente, comporta a síncope do monossílabo “sim” no último verso, como que a expressar a ruptura irreversível com uma regularidade orgânica). ${ }^{254}$

No poema "Passagem da noite”, a problemática do "sino” volta a figurar-se:
1. É noite. Sinto que é noite
2. não porque a sombra descesse
3. (bem me importa a face negra)
4. mas porque dentro de mim,
5. $\quad$ no fundo de mim, o grito
6. se calou, fez-se desânimo.
7. Sinto que nós somos noite,
8. que palpitamos no escuro

\footnotetext{
253 Note-se que "sino" equivale, também, a "chinês", a que há menções por todo o livro, inclusive no "hermético" poema "Campo, chinês e sono".

254 Em Henri LEFEBVRE, op. cit., p. 20-39, há menção ao conceito psicanalítico de "trauma" como a repetição linear de um evento na subjetividade como recurso patológico diante de um evento mal-assimilado pelo psiquismo. De acordo com Lefebvre, a psicanálise freudiana se constitui num momento em que se abandona a ruptura, no campo das ciências, entre a física e a metafísica, tidas até então como campos de conhecimento específicos, em que apenas o segundo, e não o primeiro, deveriam ser alvos da investigação filosófica. O grande marco, nesse sentido, foi a filosofia de Marx.
} 
9. e em noite nos dissolvemos.

10. Sinto que é noite no vento,

11. noite nas águas, na pedra.

12. E que adianta uma lâmpada?

13. E que adianta uma voz?

14. É noite no meu amigo.

15. É noite no submarino.

16. É noite na roça grande.

17. É noite, não é a morte, é noite

18. de sono espesso e sem praia.

19. Não é dor, nem paz, é noite,

20. é perfeitamente a noite.

21. Mas salve, olhar de alegria!

22. E salve, dia que surge!

23. Os corpos saltam do sono,

24. o mundo se recompõe.

25. Que gozo na bicicleta!

26. Existir: seja como for.

27. A fraterna entrega do pão.

28. Amar: mesmo nas canções.

29. De novo andar: as distâncias,

30. as cores, posse das ruas.

31. Tudo que à noite perdemos

32. se nos confia outra vez.

33. Obrigado, coisas fiéis!

34. Saber que ainda há florestas,

35. sinos, palavras; que a terra

36. prossegue o seu giro, e o tempo

37. não murchou; não nos diluímos.

38. Chupar o gosto do dia!

39. Clara manhã, obrigado,

40. o essencial é viver!

Em duas estrofes simétricas (em número de versos, na presença regular de redondilhas maiores e na complementaridade do esquema noite / dia), a "noite” (com o seu princípio totalitário e destrutivo) dá lugar ao “dia” (com o seu princípio de experiência regular e reconstrução), dissolvendo-se, assim, o processo semanticamente fragmentário numa síntese regenerativa (este é um dos poucos poemas em que a regularidade formal não sofre o truncamento irônico de recursos como o enjambement).

"Florestas, sinos, palavras" equivalem-se como um antídoto contra o semsentido reificante do mundo industrial, assentado no medo (como fator desagregador), nas relações mecânicas (como impossibilidade do orgânico) e no descrédito da comunicação verbal (suplantada pela separação neurótica entre significante e significado). 
No poema “Uma hora e mais outra”, essa “passagem da noite” também figura-se como possibilidade de transfiguração do tempo reificado, produto da "marcha do mundo capitalista”. Àquela “marcha” (que pressupõe a invasão da experiência diária pela lógica totalitária do “negócio”), opõe-se uma “contra-marcha”:

95. Amigo, não sabes

96. que existe amanhã?

97. Então um sorriso

98. nascera no fundo

99. de tua miséria

100. e te destinara

101. a melhor sentido.

102. Exato, amanhã

103. será outro dia.

104. Para ele viajas.

105. Vamos para ele.

106. Venceste o desgosto,

107. calcaste o indivíduo,

108. já teu passo avança

109. em terra diversa.

110. Teu passo: outros passos

111. ao lado do teu.

112. O pisar de botas,

113. outros nem calçados,

114. mas todos pisando,

115. pés no barro, pés

116. n'água, na folhagem,

117. pés que marcham muitos,

118. alguns se desviam,

119. mas tudo é caminho.

120. Tantos: grossos, brancos,

121. negros, rubros pés,

122. tortos ou lanhados,

123. fracos, retumbantes,

125. gravam no chão mole

126 marcas para sempre:

127. pois a hora mais bela

128. surge da mais triste.

A “contra-marcha” do "tu”, proposta pelo “eu” como um “amanhã”, em lugar de "uma hora e mais outra” (que é o tempo tripartido em "manhã / tarde / noite" / “trabalhar, comer, dormir”) é, no entanto, tão ritmicamente sugestiva, que se antecipa à projeção futura como um fato presente à experiência de cada leitura, na cadência regular da redondilha menor. Trata-se duma efetiva recuperação da transitividade orgânica e da 
efetiva superação das "horas” reificadas ${ }^{255}$. Que essa “contra-marcha” seja a da Resistência contra o avanço totalitário sob o ethos do medo, não há dúvida: quando não pela escala lírica e pela recusa do atomismo liberal (v. 126-127), ou então do coletivismo despersonalizante (v. 110-111), ao menos pelas imagens metonímicas (e “chãs”, apesar do sopro épico) de igualitarismo fraternitário (v. 110-119).

Há que se notar que a interlocução entre o "eu” e o "tu” é um gauchismo que se parece muito com o de "Consolo na praia":

1. Vamos, não chores...

2. A infância está perdida.

3. A mocidade está perdida.

4. Mas a vida não se perdeu.

5. O primeiro amor passou.

6. O segundo amor passou.

7. O terceiro amor passou.

8. Mas o coração continua.

9. $\quad$ Perdeste o melhor amigo.

10. Não tentaste qualquer viagem.

11. Não possuis casa, navio, terra.

12. Mas tens um cão.

13. Algumas palavras duras,

14. em vos mansa, te golpearam.

15. Nunca, nunca cicatrizam.

16. Mas, e o humour?

17. A injustiça não se resolve.

18. À sombra do mundo errado

19. murmuraste um protesto tímido.

20. Mas virão outros.

21. Tudo somado, devias

22. precipitar-te, de vez, nas águas.

23. Estás nu na areia, no vento...

24. Dorme, meu filho.

Por sob a interlocução aparentemente sarcástica, há a confissão duma dor insuportável, que pede um sono tão desamparado como o de "Vida menor" (com ser um exílio psiquicamente necessário). Assim, tanto “Uma hora e mais outra” como "Consolo na praia” denunciam um “presente” situado precisamente no tempo e no espaço (cuja

255 Supera-se, ritmicamente, a linearidade mecânica por uma regularidade cíclica, porque a métrica se vê sob a regência da dimensão semântica. 
figuração, entretanto, não implica um "presentismo"), e nesse "presente” situam, também, a condição da subjetividade lírica, ainda que "Uma hora e mais outra” recorra à projeção do "amanhã” para relativizar a "aporia”, enquanto, em "Consolo na praia”, há o recurso ao “sono-exílio”. (Em ambos, contudo, a escala é sempre a do lirismo e a da experiência individual no dia-a-dia.)

Se o "eu” de "Uma hora e mais outra” projeta, para solucionar a aporia do "tu”, a “contra-marcha” (que, entre outros aspectos, é a superação do individualismo burguês), o "eu” do poema "Movimento da espada" também se coloca nesta "contra-marcha”, embora não como sujeito dela, mas como objeto.

1. Estamos quites, irmão vingador.

2. Desceu a espada

3. e cortou o braço.

4. Cá está ele, molhado em rubro.

5. Dói o ombro, mas sobre o ombro

6. tua justiça resplandece.

7. Já podes sorrir, tua boca

8. moldar-se em beijo de amor.

9. Beijo-te, irmão, minha dívida

10. está paga.

11. Fizemos as contas, estamos alegres.

12. Tua lâmina corta, mas é doce,

13. a carne sente, mas limpa-se.

14. O sol eterno brilha de novo

15. e seca a ferida.

16. Mutilado, mas quanto movimento

17. em mim procura ordem.

18. O que perdi se multiplica

19. e uma pobreza feita de pérolas

20. salva o tempo, resgata a noite.

21. Irmão, saber que és irmão,

22. na carne como nos domingos.

23. $\quad$ Rolaremos juntos pelo mar...

24. Agasalhado em tua vingança,

25. puro e imparcial como um cadáver que o ar embalsamasse,

26. serei carga jogada às ondas,

27. mas as ondas, também elas, secam,

28. e o sol brilha sempre.

29. Sobre minha mesa, sobre minha cova, como brilha o sol!

30. Obrigado, irmão, pelo sol que me deste, 
31. na aparência roubando-o.

32. Já não posso classificar os bens preciosos.

33. Tudo é precioso...

34. e tranqüilo

35. como olhos guardados nas pálpebras.

Trata-se, de fato, de um poema, mais que irônico, sarcástico. A violência do "eu” contra si próprio é bastante expressiva. Reitere-se, entretanto, a necessidade de separar a dimensões de autoria e persona lírica. Entender que, neste poema, Drummond opera uma simples confissão de culpa nos parece bastante restritivo. O eu-lírico e o "tu” (o “irmão vingador”), na verdade, dramatizam o desejo de redenção que percorre o trânsito, por toda A rosa do povo, da subjetividade pelos aspectos interiores e exteriores do real. O distanciamento dramático do lirismo diante do processo figurativo é mais um dos recursos literários de que o Gauche se serve para figurar a complexidade do seu lirismo “engajado".

Esse recurso figurativo é tão complexo que não permite afirmar, em absoluto, a plena identidade do poeta com certas interpretações do pensamento marxista, como a problemática da "luta de classes”. Como já observamos, a idéia do “proletariado” como classe ontologicamente portadora dos destinos inexoráveis da História, e a idéia do socialismo como etapa final da luta de classes, em que as contradições se resolvem numa síntese que não inaugurará mais nenhum conflito, são interpretações do pensamento marxista de que o poema "O mito" escarnece. O poema "Movimento da espada”, visto por essa perspectiva, parece contradizer essa dimensão de “O mito” e o próprio caráter reflexivo da poética drummondiana, em que as adesões a idéias ou conceitos, quando acontecem, são inevitavelmente parciais; não há contradição, entretanto, quando se nota que as dimensões da(s) persona(e) e da subjetividade lírica não coincidem.

Não há, em A rosa do povo, uma única manifestação do personagem Gauche, mas sim diferentes papéis e diversas personae. Em “A flor e a náusea”, por exemplo, os indícios de que a persona lírica remete à pequena burguesia são grandes:

1. Preso à minha classe e a algumas roupas,

2. vou de branco pela rua cinzenta.

3. Melancolias, mercadorias espreitam-me.

4. Devo seguir até o enjôo?

5. Posso, sem armas, revoltar-me? 
Naquele contexto, os hábitos de vestuário eram também indício de “classe”, mas a "náusea” que a condição burguesa provoca na subjetividade lírica, se por um lado leva à consciência de pertencimento, por outro motiva o desejo de ruptura com essa identidade, que é muito mais um resultado objetivo (do olhar que parte da condição exterior, mas que não encontra eco na interioridade) que subjetivo (a interioridade não se reconhece nem no espaço objetivo, nem identifica a sua condição objetiva com a sua escala subjetiva de valores). É esse percurso identitário complexo que percorre todo $A$ rosa do povo, todas as mais diversas manifestações (personae) da subjetividade lírica do Gauche. Vejam-se, nesse sentido, diversos outros poemas, como “Noite na repartição”, “Indicações” e “Os últimos dias”.

Em “Noite na repartição”, figura-se a condição reificada, solitária e sem sentido do funcionário-público. A despersonalização do homem pelo seu papel social (já apontada em poemas como "O medo") é alvo duma comicidade que se serve dos elementos da dramaturgia, cuja linguagem é parodiada, como forma de encenar o conflito íntimo do personagem. Assim, o “OFICIAL ADMINISTRATIVO”, O "PAPEL”, “A PORTA”, “A ARANHA”, “A GARRAFA DE UÍSQUE”, “O GARRAFÃO DE CACHAÇA”, “O COQUETEL”, “TODOS OS ÁlCOOIS”, “A TRAÇA”, “O TELEFONE”, “A VASSOURA ELÉTRICA”, “OS PROCESSOS” e “A POMBA" contracenarão como personagens distintos, mas, por sob o nível do enunciado, o que há é o drama lírico do pequeno burguês cuja subjetividade vê-se restrita por sua função social, que a restringe a poucas possibilidades.

Em “Indicações”, há também uma dimensão autobiográfica, na figura de um "tu” (que se percebe, nitidamente, ser um desdobramento do próprio eu lírico, em devaneio):

1. Talvez uma sensibilidade maior ao frio,

2. desejo de voltar mais cedo para casa.

3. $\quad$ Certa demora em abrir o pacote de livros

4. esperado, que trouxe o correio.

5. Indecisão: irei ao cinema?

6. $\quad$ Dos três empregos de tua noite escolherás: nenhum.

7. Talvez certo olhar, mais sério, não ardente,

8. que pousas nas coisas, e elas compreendem.

9. Ou pelo menos supões que sim. São fiéis as coisas

10. do teu escritório. A caneta velha. Recusas a trocá-la

11. pela que encerra o último segredo químico, a tinta imortal.

12. Certas manchas na mesa, que não sabes se o tempo, 
13. se a madeira, se o pó trouxeram consigo.

14. Bem a conheces, tua mesa. Cartas, artigos, poemas

15. saíram dela, de ti. Da dura substância,

16. do calmo, da floresta partida elas vieram,

17. as palavras que achaste e juntaste, distribuindo-as.

18. A mão passa

19. na aspereza. O verniz se foi. Não. É a árvore

20. que regressa. A estrada voltando. Minas que espreita,

21. e espera, longamente espera tua volta sem som.

A persona do "poeta", aqui, talvez esteja muito mais próxima do autor que nos demais poemas, mas demonstra que a preocupação autobiográfica é central já em A rosa do povo. Entretanto, na poética drummondiana, nunca há coincidência entre o eu e a sua representação, e essa é uma maneira que aparentemente despesonaliza, quando, ao contrário, trata-se de um alcance lírico profundo. No caso de “Indicações”, devidamente contextualizado no lirismo de múltiplas personae de A rosa do povo, o que se percebe é que a concepção de homem, se comporta a dimensão político-sociológica, não prescinde de outras dimensões, as quais incluem a experiência humana mais diretamente cotidiana, ou então o que se poderia chamar de uma perspectiva "existencial” (conceito que não se quer vincular com nenhum sistema filosófico em específico).

Depois de situar-se no momento do "descanso” (“dos três empregos de tua noite escolherás: nenhum.”), o eu lírico, em diálogo consigo mesmo, prossegue com a ampliação da sua consciência para além do cotidiano. Sem abandonar, objetivamente, o espaço de moradia, a consciência lírica dirige-se, no entanto, para uma outra perspectiva sobre si própria: a da morte como finitude e, portanto, como encerramento da experiência vital, e dos seus significados.

22. A mesa se torna leve, e nela viajas

23. em ares de paciência, acordo, resignação.

24. Olhai a mesa que foge, não a toqueis. É a mesa volante,

25. de suas gavetas saltam papéis escuros, enfim os libertados segredos

26. sobre a terra metálica se espalham, se amortalham e calam-se.

27. De novo aqui, miúdo território

28. civil, sem sonhos. Como pressentindo

29. que um dia se esvaziam os quartos, se limpam as paredes,

30. e pára um caminhão e descem carregadores,

31. e no livro municipal se cancela um registro,

32. olhas fundamente o risco de cada

33. coisa, a cor 
34. de cada face dos objetos familiares.

O devaneio termina com o retorno da consciência à condição objetiva e cotidiana do corpo, mas enriquecida pela consciência de que há outras temporalidades possíveis, em especial pela consciência da finitude como condição humana: mortal. A imagem do “rosto sobre a mesa” é a própria sobreposição da condição mortal sobre a vida, em seu curso cotidiano.

53. Como saber? A princípio parece deserto,

54. como se nada ficasse, e um rio corresse

55. por tua casa, tudo absorvendo.

56. Lençóis amarelecem, gravatas puem,

57. a barba cresce, cai, os dentes caem,

58. os braços caem,

59. caem partículas de comida de um garfo hesitante,

60. as coisas caem, caem, caem,

61. e o chão está limpo, é liso.

62. Pessoas deitam-se, são transportadas, desaparecem,

63. e tudo é liso, salvo teu rosto

64. sobre a mesa curvado; e tudo é imóvel.

Aqui, nada parece condenar a condição pequeno-burguesa do "poeta” como pouco “revolucionária”, quando, ao contrário, a visada autobiográfica transcende a mera confissão, e alcança a condição mortal de qualquer homem (que em princípio não diz respeito, necessariamente, a categorias sociológicas), sendo, por esse prisma, libertária, complementar à denúncia da reificação no tempo tripartite. Que, no devaneio à "hora do descanso” a lógica utilitária não contamine a dimensão psíquica, trata-se de uma visada complementar à da “contra-marcha” - sendo, também, a seu modo, libertária.

O poema “Os últimos dias”, que se parece bastante com “Indicações”, legitima essa complementaridade entre a perspectiva “existencial” e a perspectiva "política” (o que, de resto, a própria contaminação do privado pelo público já apontava, em “Nosso tempo").

1. Que a terra há de comer.

2. Mas não coma já.

3. Ainda se mova,

4. para o ofício e a posse.

5. E veja alguns sítios 
6. antigos, outros inéditos.

7. Sinta frio, calor, cansaço;

8. pare um momento; continue.

9. Descubra em seu movimento

10. forças não sabidas, contatos.

11. O prazer de estender-se; o de

12. enrolar-se, ficar inerte.

13. Prazer de balanço, prazer de vôo.

14. Prazer de ouvir música;

15. sobre papel deixar que a mão deslize.

16. Irredutível prazer dos olhos;

17. certas cores: como se desfazem, como aderem;

18. certos objetos, diferentes a uma luz nova.

19. Que ainda sinta cheiro de fruta,

20. de terra na chuva, que pegue,

21. que imagine e grave, que lembre.

22. O tempo de conhecer mais algumas pessoas,

23. de aprender como vivem, de ajudá-las.

Nestes primeiros versos, em reforço à idéia de gratuidade, o que se vê é a afirmação de um ethos em tudo contrário ao ethos burguês (o princípio associal e atomizante do medo). A afirmação do prazer sensual e do impulso erótico (nos sentido amplo de "gregário”) como contraponto à morte (entendida como impossível transcendência diante da finitude literal e simbólica) assume, a um tempo, a perspectiva da experiência, ou do vivido, e a perspectiva da condição mortal e incontornável de todo ser humano.

24. [Que ainda haja tempo] De ver passar este conto: o vento

25. balançando a folha; a sombra

26. da árvore, parada um instante,

27. alongando-se com o sol, e desfazendo-se

28. numa sombra maior, de estrada sem trânsito.

29. E de olhar esta folha, se cai.

30. Na queda retê-la. Tão seca, tão morna. 
Em mais uma manifestação de metalirismo, o que chama a atenção é a figuração do entrecho poético dos v. 24-30 como "conto”, cujo sentido é polissêmico: funciona no sentido de uma narrativa (que, em "Nosso tempo", enuncia-se impossível, uma vez que a subjetividade encontra-se interdita pela objetividade reificante) e funciona, também, como referência, não mais a “poesia”, mas na ampliação deste gênero pela incorporação de outras possibilidades literárias. Que alguns poemas de A rosa do povo assumem a tonalidade da crônica, do memorialismo, do ensaio, das análises sociológicas e de outras gêneros que não o, até então, entendido como propriamente "poético", isto não é novidade, e vem enunciado, mesmo, já no primeiro poema da coletânea (o poemapoética “Consideração do poema”, ele também uma espécie de “manifesto”). Cabe, então, frisar este aspecto em "Os últimos dias” para que se perceba, ao longo de todo o livro, que o caráter libertário do “poema” vai também no sentido de colocar quaisquer recursos figurativos (em termos de gênero ou em quaisquer outros termos) a serviço da necessidade expressiva. ${ }^{256}$

31. [Esta folha que cai] Tem na certa um cheiro, particular entre mil.

32. Um desenho, que se produzirá ao infinito,

33. e cada folha é uma diferente.

34. E cada instante é diferente, e somos todos iguais.

35. No mesmo ventre o escuro inicial, na mesma terra

36. o silêncio global, mas não seja logo.

O significado do igualitarismo enunciado nestes versos, e reiterado obsessivamente em seguida (v. 48, 52, 53-58), está longe de apenas apontar para uma militância marxista-leninista, como o parecem fazer os poemas “engajados” da lírica de guerra. Neste enunciado, obsessivo e catártico, está, não apenas a afirmação de um ethos, mas o seu refinamento. Em primeiro lugar, atente-se para o fato, que vimos reiterando, de que é da escala do indivíduo e do vivido que se trata (e não a do heroísmo monumental das massas). Essa escala não nega (porque fundamenta) a perspectiva da coletividade (ainda que pressuponha a "solidão", mas como condição reversível). Observe-se, contudo, que a "igualdade” é o reverso da “diferença”, e não a sua simples negação, e o sentido desse "nivelamento na pluralidade” é a liberdade do imprevisível. Em suma, o igualitarismo contrapõe-se a quaisquer atentados contra a liberdade, ethos sobre o qual se assentam as relações de fraternidade, em nenhum aspecto hierárquicas.

${ }^{256}$ Cf. Antonio CANDIDO, "Inquietudes na poesia de Drummond", in Vários escritos, p. 144. 
Para além do "engajamento" imediato, o que se vê, por sob o enunciado, é uma participação reflexiva, que põe em retrospectiva quaisquer outros sentidos de “participação política” no contexto da coletânea. (“Os últimos dias” é o antepenúltimo poema do livro.)

37. Antes dele outros silêncios penetrem,

38. outras solidões derrubem ou acalentem

39. meu peito; ficar parado em frente desta estátua: é um torso

40. de mil anos, recebe minha visita, prolonga

41. para trás meu sopro, igual a mim

42. na calma, não importa o mármore, completa-me.

43. O tempo de saber que alguns erros caíram, e a raiz

44. da vida ficou mais forte e os naufrágios

45. não cortaram essa ligação subterrânea entre homens e coisas:

46. que os objetos continuam, e a trepidação incessante

47. $\quad$ não desfigurou o rosto dos homens;

48. que somos todos irmãos, insisto.

49. Em minha falta de recursos para dominar o fim,

50. entretanto me sinta grande, tamanho de criança, tamanho de torre,

51. tamanho da hora, que se vai acumulando século após século e causa vertigem,

52. tamanho de qualquer João, pois somos todos irmãos.

53. E a tristeza de deixar os irmãos me faça desejar

54. partida menos imediata. Ah, podeis rir também,

55. não da dissolução, mas do fato de alguém resistir-lhe,

56. de outros virem depois, de todos sermos irmãos,

57. no ódio, no amor, na incompreensão e no sublime

58. cotidiano, tudo, mas tudo é nosso irmão.

59. O tempo de despedir-me e contar

60. que não espero outra luz além da que nos envolveu

61. dia após dia, noite em seguida a noite, fraco pavio,

62. pequena ampola fulgurante, facho, lanterna, faísca,

63. estrelas reunidas, fogo na mata, sol no mar,

64. mas que essa luz basta, a vida é bastante, que o tempo

65. é boa medida, irmãos, vivamos o tempo.

A "solidão", "no mesmo ventre o escuro inicial, na mesma terra / o silêncio global”, “outros silêncios”, “outras solidões”, “essa ligação subterrânea entre homem e coisas”: todas essas expressões parecem confirmar a escala do vivido e do(s) indivíduo(s) como antídoto contra qualquer "sublime” que não tenha como referência o “cotidiano”, e se encaminhe em direção ao monumental e à despersonalização (e que, portanto, não é mais “sublime”). A condição finita não se vê negada pelo simbólico, 
mas tampouco se resigna ao empobrecimento das significações intransitivas; o "torso de mil anos” pode, perfeitamente, ampliar a condição mortal e individual em direção a uma pluralidade de significados, de tempos e de espaços, sem que, com isso, deva-se operar a separação platonizante entre corpo / alma, significante / significado ou quaisquer outras dicotomias que tais. A transfiguração da “aporia” em "flor antieuclidiana”257 é um ato que resulta da "escavação" em direção à "raiz da vida".

66. A doença não me intimide, que ela não possa

67. chegar até aquele ponto do homem onde tudo se explica.

68. Uma parte de mim sofre, outra pede amor,

69. outra viaja, outra discute, uma última trabalha,

70. sou todas as comunicações, como posso ser triste?

71. A tristeza não me liquide, mas venha também

72. na noite de chuva, na estrada lamacenta, no bar fechando-se,

73. que lute lealmente com sua presa,

74. e reconheça o dia entrando em explosões de confiança,

75. esquecimento, amor,

76. ao fim da batalha perdida.

77. Este tempo, e não outro, sature a sala, banhe os livros,

78. nos bolsos, nos pratos se insinue: com sórdido ou potente clarão.

79. E todo o mel dos domingos se tire;

80. o diamante dos sábados, a rosa

81. de terça, a luz de quinta, a mágica

82. de horas matinais, que nós mesmos elegemos

83. para nossa pessoal despesa, essa parte secreta

84. de cada um de nós, no tempo.

85. E que a hora esperada não seja vil, manchada de medo,

86. submissão ou cálculo. Bem sei, um elemento de dor

87. rói sua base. Será rígida, sinistra, deserta,

88. mas não a quero negando as outras horas nem as palavras

89. ditas antes com voz firme, os pensamentos

90. maduramente pensados, os atos

91. que atrás de si deixaram situações.

92. Que o riso sem boca não a aterrorize,

93. e a sombra da cama calcária não a encha de súplicas,

94. dedos torcidos, lívido

95. suor de remorso.

A aceitação da condição finita e ontologicamente sem transcendência é a própria aceitação e o reconhecimento da historicidade na perspectiva do indivíduo. Para essa

257 Menção ao v. 13 do poema “Áporo”. 
condição, só há transcendência, mas relativa, nos sentidos (principalmente no seu desregramento).

96. E a matéria se veja acabar: adeus, composição

97. que um dia se chamou Carlos Drummond de Andrade.

98. Adeus, minha presença, meu olhar e minhas veias grossas,

99. meus sulcos no travesseiro, minha sombra no muro,

100. sinal meu no rosto, olhos míopes, objetos de uso pessoal, idéias de justiça,

101. vida aos outros legada.

[revolta e sono, adeus,

Como no poema anterior (“Indicações”, mas também em “Morte no avião” e em “Versos à boca da noite”), a perspectiva da morte se faz importante, muito embora não negue (antes, reforça) a temporalidade cotidiana do vivido, e esta é uma das características da "maturidade" que o Gauche figura por todo o percurso de A rosa do povo, e que não se aparta do "engajamento". Em "Os últimos dias", a "face” propriamente autoral, autobiográfica, do poeta figura-se da maneira mais íntegra, em relação a todos os poemas da coletânea, "escrevendo-se" em toda a extensão do seu nome. A completude da sua identidade nesse poema é, entretanto, um índice da complementaridade de todas as "faces” do Gauche, que se figuram por todo o livro, e que têm como desejo explícito a redenção de si e do mundo.

8

Percebe-se que, em todos esses poemas, o percurso subjetivo vai da dimensão mais afeita à objetividade cotidiana até uma outra dimensão, aparentemente dissociada da primeira, e que se poderia chamar de "existencial”, mas que, na verdade, complementa, porque enriquece, a percepção do cotidiano. Sob essa pluralidade “temática”, no entanto, há sempre a figuração, ou do ato da escrita, ou então da imagem do "poeta”. Figurado na escala do vivido e do indivíduo, o "cotidiano” torna-se polissêmico, na medida em que denuncia a "marcha do mundo capitalista", sem, com isso, restringir-se à sua lógica utilitária e despersonalizante (ainda que, também, não se despolitize). 
O exame mais atento do gauchismo no contexto mais amplo da coletânea (e não restrito à imediata textualidade de cada poema) implica que se amplie a noção de “engajamento”. Percebe-se, dessa forma, que não há adesão irrestrita a corpos teóricos e / ou ideológicos, porque a forma poética configura um sistema simbólico muito próprio, um pensamento propriamente literário, lírico, em que a “participação” se insere num contexto maior, mediado, que não comporta, em nenhum momento, a coincidência absoluta entre o(s) tempo(s) do(s) texto(s) e o(s) tempo(s) do(s) contexto(s).

Nesses termos, percebe-se que a problemática histórico-sociológica da "luta de classes” incorpora-se ao texto, mas, por mediação da forma, é temerário identificar, na coletânea, a mera condenação da pequena burguesia como “classe” intrinsecamente conservadora, ou então a glorificação do “povo”, na figura do "proletário”, como classe ontologicamente revolucionária $^{258}$, quando, na verdade, os papéis sociais, embora figurem-se como fator fundamental de humanização ou reificação, contudo não esgotam a condição humana mais ampla, rica em experiências de naturezas múltiplas.

Se essa visada não é própria a momentos em que a ação sobrepõe-se à reflexão (como no caso da conjuntura mundial sob a Resistência ao nazi-fascismo), ela, entretanto, revela-se uma problemática estrutural na poesia escrita por Drummond naquele momento e reunida em livro em 1945, o que permite concluir que a participação literária nos eventos conjunturais supera o impasse entre uma suposta incompatibilidade entre estética e política, sem prejuízo para nenhuma das duas esferas (que se revelam concorrentes).

\footnotetext{
258 Em "Drummond Héautontimorouménos: culpa social", Vagner CAMILO (in Drummond, da rosa do povo à rosa das trevas, p. 243-261) acompanha a figuração da culpa, desde o seu papel redentor nos anos 1940 (a partir do engajamento de Sentimento do mundo) até o aparente absenteísmo de Claro enigma (quando a culpa abandona a perspectiva de redenção). Em fina análise sobre poemas de Sentimento do mundo (notadamente "Confidência do Itabirano", "Sentimento do mundo" e "O operário no mar") , o estudioso afirma: "A perda de status, se implica depauperização, não chega a igualar o filho de fazendeiro ao nível daqueles a quem dirige seu apelo solidário, seja o operário, o habitante do morro ou do subúrbio. A distância social persiste e é da consciência de sua insuperabilidade - portanto da impossibilidade de identificação integral - que redunda a culpa social. A grandeza e permanência da poesia social de Drummond - como já se observou na primeira parte do livro reside justamente no empenho solidário sem contudo ofuscar a consciência dessa distância social em favor da atitude paternalista ou populista." (p. 247)
} 


\section{CAPÍTULO 6}

\section{UMA, DUAS ARGOLINHAS}

(CIDADE PREVISTA) 


\title{
CAPÍTULO 6 - Uma, duas argolinhas (cidade prevista)
}

\author{
A poesia fugiu dos livros, agora está nos jornais. \\ Os telegramas de Moscou repetem Homero. \\ Mas Homero é velho. Os telegramas cantam um mundo novo \\ que nós, na escuridão, ignorávamos. \\ Fomos encontrá-lo em ti, cidade destruída, \\ na paz de tuas ruas mortas mas não conformadas, \\ no teu arquejo de vida mais forte que o estouro das bombas, \\ na tua fria vontade de resistir. \\ ("Carta a Stalingrado")
}

Reiteremos que, em A rosa do povo, a análise temática não deve perder de vista que se trata de uma poética processual, em que não há propriamente assuntos, mas núcleos temáticos, todos imbricados nas “inquietudes” líricas de uma "subjetividade tirânica”. O eu e a participação política nos eventos da conjuntura são "temas" fundamentais, integrados pelo lirismo “inquieto”, cuja síntese se opera no metalirismo $^{259}$. O metalirismo é tão central na integridade do pensamento poético de $A$ rosa do povo que já se entrevê no próprio título da coletânea, bem como nos seus dois primeiros poemas (verdadeiros “manifestos” literários e, ao mesmo tempo, poemas radicalmente líricos). A imagem da "flor", entre todas as outras imagens metalíricas da coletânea, é fundamental, porque representa, alegoricamente, as “pétalas” (ou os recursos lingüísticos) do fazer poético, e, ao mesmo tempo, desfigurando-as, termina invariavelmente por transfigurá-las.

Procurar os significados do “engajamento” drummondiano na obra de 1945 pressupõe, portanto, que se investigue o trânsito entre os "temas" de eu e mundo, cuja síntese, no plano da forma, é a metalírica. Investigar o processo do lirismo que se figura

${ }^{259}$ Antonio CANDIDO, "Inquietudes na poesia de Drummond", in Vários escritos. 
a si próprio é fundamental para tratar do "tema do engajamento", percebendo-o em suas dimensões dinâmicas, complementares de significante / significado.

“Cidade prevista” é o terceiro poema do "bloco do engajamento"; ele precede a “lírica de guerra”, anunciando a dimensão “épica” da Resistência ao Nazi-fascismo.

\section{Guardei-me para a epopéia \\ 2. que jamais escreverei.}

O poema, todo em redondilhas maiores (com as exceções expressivas dos versos octassílabos 35 e 36), de fato, não se pode classificar como uma “epopéia” (como, de resto, nenhum dos poemas em $A$ rosa do povo). ${ }^{260}$ Mas o nível do enunciado, embora referencialmente exato, está longe de esgotar todas as possibilidades de significação do poema, porque o seu discurso é propriamente “poético”, uma vez que os seus significados, densos, constroem-se por correlações lingüísticas complexas entre os diversos níveis significantes.

Note-se que, em vez de apenas enunciar a "precariedade poética”, o seu processo significante, na verdade, figura “como” e “quando” uma “epopéia” poderá ser entoada (não “agora”, nem com “estas” condições, tanto subjetivas como objetivas ${ }^{261}$ ). Se o eu lírico enuncia a sua incapacidade de tecer um “canto épico” sobre a sua "pólis”, no momento "presente” (e em qualquer outro), é importante perceber que, ao mesmo tempo, ele projeta o seu desejo em “outro momento”, atribuindo-o a “outros poetas”.

\footnotetext{
260 Joaquim Alves de AGUIAR (in Espaços da memória, p. 25-26) afirma: "Memória escrita é narração. A palavra vem do verbo latino narrare, que significa expor, contar, relatar, e se aproxima do que os gregos antigos chamavam de épikos: poema longo que conta uma história e serve para ser recitado. É assim que, sendo arte narrativa por excelência, o memorialismo se liga à épica, tal como acontece com a novela, o conto e o romance. De modo semelhante ao gênero clássico, o memorialismo exige a presença de um narrador apresentando os acontecimentos e os personagens neles envolvidos e pressupõe sempre dois tempos: o presente em que se narra e o passado em que ocorrem os eventos narrados. As formas épicas são necessariamente posteriores aos acontecimentos que representam. Sendo assim, para o épico é necessária a distância no tempo, entre o presente e o passado, mas é este que deve ressurgir como matéria da épica. A busca do passado, porém, nunca o reencontra de modo inteiriço, porque todo ato de recordar transfigura as coisas vividas. $\mathrm{Na}$ épica, como na memória, o passado se reconstrói de maneira alinear com idas e voltas repentinas, com superposição de planos temporais, com digressões e análises. Naturalmente, o que retorna não é o passado propriamente dito, mas suas imagens gravadas na memória e ativadas por ela num determinado presente."

261 O posicionamento do eu lírico encontra-se marcado nos v. 42-43, vejam-se os dêiticos "este" e "ainda".
} 
15. Cantai esse verso puro,

16. que se ouvirá no Amazonas,

17. na choça do sertanejo

18. e no subúrbio carioca,

19. no mato, na vila $X$,

20. no colégio, na oficina,

21. território de homens livres

22. que será nosso país

23. e será pátria de todos.

24. Irmãos, cantai esse mundo

25. que não verei, mas virá

26. um dia, dentro em mil anos,

27. talvez mais... não tenho pressa.

28. Um mundo enfim ordenado,

29. uma pátria sem fronteiras,

30. sem leis e regulamentos,

31. uma terra sem bandeiras,

32. sem igrejas nem quartéis,

33. sem dor, sem febre, sem ouro,

34. um jeito só de viver,

35. mas nesse jeito a variedade,

36. a multiplicidade toda

37. que há dentro de cada um.

38. Uma cidade sem portas,

39. de casas sem armadilha,

40. um país de riso e glória

41. como nunca houve nenhum.

42. Este país não é meu

43. nem vosso ainda, poetas.

44. Mas ele será um dia

45. o país de todo homem.

É interessante notar como os diversos termos passam a se equivaler no "projeto" literário de "cantar epicamente” a “cidade prevista”: “território de homens livres” (v. 21), “nosso país” (v. 22), “pátria de todos” (v. 23), “um mundo enfim ordenado” (v. 28), “uma pátria sem fronteiras, / sem leis e sem regulamentos” (v. 29-30), “uma terra sem bandeiras, / sem igreja nem quartéis, / sem dor, sem febre, sem ouro” (v.31-33), “uma cidade sem portas / de casas sem armadilha” (v.38-39), “um país de riso e glória / como nunca houve nenhum” (v. 40-41), “este país” (v. 42).

Percebe-se, nesse “projeto poético”, um retrato em negativo do espaço-tempo vivido, contemporâneo, o qual pode ser uma representação do "nosso país”, mas que sem dúvida equivale a outros “territórios” interditos, no “mundo (des)ordenado” pela 
lógica de "fronteiras” nacionais em disputa, estigmatizado pelo ethos burguês da "física do medo" 262 .

Tratados no “diálogo” por “vós”, os “poetas” recebem, como “sugestão lírica”, um "projeto" cuja temporalidade, entretanto, marca mais o "tempo presente, os homens presentes, a vida presente"263 que um tempo-espaço suposto, embora essa marca se imprima em negativo.
3. $\quad$ Poetas de Minas Gerais
4. e bardos do Alto Araguaia,
5. vagos cantores tupis,
6. recolhei meu pobre acervo,
7. alongai meu sentimento.
8. O que eu escrevi não conta.
9. O que desejei é tudo.
10. Retomai minhas palavras,
11. meus bens, minha inquietação,
12. fazei o canto ardoroso,
13. cheio de antigo mistério
14. mas límpido e resplendente.

A temporalidade do “desejo”, ainda que enunciada no pretérito (“o que desejei”), remete menos a um passado objetivo que a um "passado" imaginado, possível, mas “ainda não”(v. 42-45) efetuado. Esse “passado” do desejo e da imaginação remete a um “antigo mistério / mas límpido e resplendente”, que é uma projeção dirigida a um tempo suposto, “ainda não” acontecido, mas por acontecer, e que, entretanto, não chega a constituir um "futuro" objetivamente possível, que possa ser vislumbrado. Remete, antes, a um tempo-espaço que não se pode localizar no real "objetivo” (a não ser em termos negativos).

O "lugar” a partir do qual o “desejo” se enuncia é, em termos subjetivos, um "presente" cifrado. Esse "lugar”, em termos positivos, remete ao que se poderia conceituar como "utopia”, tomando o termo não no sentido comum (e pejorativo) de “algo impossível, inexeqüível”, mas no sentido de possibilidade volitiva, ou “projeto”, entendido como uma das dimensões do real: o psiquismo ${ }^{264}$. Vai nessa direção o sentido conotativo da qualificação para a “cidade” do título: “prevista”. Não se trata de uma

\footnotetext{
262 Expressão sugerida pelo poema "O medo" (v. 39-42, 47-50) e aplicada à interpretação de "Cidade prevista" (v. 38-39).

264 Fábio HERMANN, "Realidade", in Psicanálise do cotidiano.
} 
antevisão objetivamente possível, mas de uma projeção, em negativo, do desejo, por sobre o espaço contemporâneo, vivido.

A utopia pessoal se dirige a uma condição coletiva, expressa formalmente pela segunda do plural, cuja sugestão apenas aparentemente aproxima o poema de um tom solene, quando, na verdade, se trata de, a um tempo, criar uma situação de diálogo, mas direcionado a uma temporalidade utópica, projetiva, que denuncia o presente interdito e enuncia a sua transfiguração. Por seu tom interlocutório, o poema, em realidade lírico, aproxima-se do caráter coletivo da “epopéia”, sem abandonar, contudo, sua escala peculiar.

A “pólis” utópica , apesar da enunciada precariedade poética do "lirismo" em tornar-se “épica”, termina por figurar-se textualmente. Não à maneira do "antigo Homero”, mas à maneira “contemporânea”, projetiva, a “cidade prevista” se vê “cantada”. Se o "canto épico" será adequado a uma matéria que não se pode "cantar" adequadamente "hoje”, “aqui”, “desta forma”, “com estes recursos”, o "presente” efetivo do poema (que não é a temporalidade imperativa do enunciado, mas é a temporalidade subjetiva, utópica, do “desejo”, feita e refeita a cada leitura, e latente no texto), assume características que muito pouco têm de impasse, ou “aporia”.

A obra coletiva, eloqüente, que figura o utopicamente possível "país de todo homem” pela mediação da “epopéia”, formaliza-se, de fato, na materialidade significante do poema, em sua temporalidade simbólica, que comporta ao menos dois níveis significativos imbricados: o do significante e o do significado. Nesses termos, o “projeto” (ou “previsão”) “político” do poema é o de uma obra “épica”: coletiva, eloqüente, feita em "versos puros” (mas dirigidos a lugares “não puros”, o que os torna “mesclas” de instrumental "sublime” e significação “menor”265) e, sobretudo, constitutiva de uma “nação” muito específica (porque “internacionalista”), e surgida de um esforço heróico (a superação da beligerância ${ }^{266}$ ).

\footnotetext{
265 O poema (como diversos outros metapoemas de $A$ rosa do povo) exalta o dinamismo das relações entre autoria-obra-recepção, ao figurar, por metalinguagem, todos os elementos essenciais do discurso poético. Dessa perspectiva, a "escrita" ("o que escrevi") é apenas um dos aspectos do "poema", incompleto portanto. O discurso efetivo apenas ganha realidade quando a intenção autoral ("desejo"), por meio do potencial simbólico ("poesia), expresso numa forma concreta ("poema", ou "o que escrevi") atinge o leitor ("todo homem"), que, por sua vez, pertence a um "sistema literário", espaço-temporalmente constituído (um "território de homens livres"), ao qual também o autor (o "poeta") deve pertencer. Este seria o sentido mais refinado dos versos 8-9 de "Cidade prevista". (Esta interpretação, como é evidente, se faz a partir do conceito de literatura, proposto por Antonio CANDIDO em "A literatura e a vida social”, in Literatura e sociedade, e que é o mais adequado para o sentido drummondiano de "escrita")

260 As "fronteiras" (v. 29), as "bandeiras" (v. 31), os "quartéis" (v. 32) e demais elementos metonímicoalegóricos podem ser tomados como referências, em negativo, ao conflito nazi-fascista em proporções mundiais. O "mundo" denotativo do poema, que virá "um dia, dentro em mil anos, / talvez mais... não tenho
} 
Dessa forma, o não-lugar, retrato em negativo do lugar lírico “objetivo” do Gauche, cuja motivação tem natureza volitiva, vem mediado pela imagem metalingüística do próprio “canto”. A “epopéia”, como imagem lírica na especificidade de "Cidade prevista”, com ser uma "forma” mediadora entre um "presente” interdito e um desejo utópico, torna-se, ela mesma, um recurso simbólico ambivalente, pela denúncia da precariedade e por sua transfiguração em possibilidade.

A “epopéia” figura-se como forma adequada apenas a uma outra situação, não identificada no "presente", mas nele "projetada" como utopia (ressignificação, subversão da mimese). Se, à primeira vista, ela é sugerida como o recurso lingüístico adequado para a figuração de um "real” objetivo, que exista “de fato”, num exame mais atento, a "epopéia” se revela, contudo, uma estratégia competente em "reescrever”, ou reconsiderar, uma situação objetiva, segundo um projeto subjetivo e um instrumental de mediação e intervenção de natureza conceitual. Não se trata, portanto, de mimese, mas de mediação.

“Cidade prevista”, em outras palavras, é um poema sobre a impossibilidade da “epopéia” (e, portanto, um metapoema). Sob o enunciado da "precariedade” própria, o que há é a recusa da mimese imediata, como se o “poema”, com a sua capacidade lírica, se recusasse a “cantar” o "mundo objetivo”, esse, sim, precário (caso o fizesse, o “canto” nada teria de "épico” - como, de fato, não o tem). O “poema”, quando afirma a sua "precariedade”, está, no fundo, a constatar a precariedade do "mundo" em que vive, de tal modo interdito que, não apenas o "presente”, mas qualquer "projeto” futuro vê-se comprometido. Como “escrever” uma “epopéia” sobre um “mundo” nada “épico”? Transfigurando-o “epicamente”? Isso, no fundo, é o que o poema lírico termina por fazer: porque "projeta” uma "epopéia”, não no presente interdito, mas em sua imagem em negativo, disfarçada de “futuro", e esse projeto é atribuído, não ao eu lírico, mas ao seu disfarce de "segunda pessoa do plural” (uma persona do Gauche). A “imaginação épica” não é, com isso, propriamente mimética, mas um “projeto” de natureza “utópica” 
(um "projeto" transfigurador que, ao representar o mundo em negativo, desfigura o “tempo presente”, transfigurando-o no inverso exato da sua mimese).

A “projeção" duma subjetividade interdita não acontece apenas em "Cidade prevista”, mas também em poemas como “Vida menor” e "Nova canção do exílio”. Constitui o próprio “núcleo temático” de A rosa do povo, que são as “inquietudes” dum eu lírico cujo "sentimento", embora sempre constate um mundo fragmentário, com o qual é impossível identificar-se integralmente, nunca deixa, entretanto, de "recomeçar amanhã”267, “disfarçando-se” sob a “forma” de algum “elefante”268, por sob a qual a melancolia não se faz resignação.

À medida que a examinamos, a figura do gauche que Drummond projeta sobre si mesmo vai-se tornando mais complexa: como persona poética, como síntese psicológica, como lugar social. Se o que logo salta à vista são as carências implícitas da figura, a força com que se dá sua expressão deixa o efeito de uma consciência final, lucidamente compensatória. A timidez e o desajustamento já chegam ao leitor devidamente ponderados pelo próprio sujeito, dono do seu espelho. Impossibilitados de nos distrairmos com o sópatético, temos que nos haver com a problemática composição entre estado lírico e consciência, entre emoção e argumento, entre confissão e ironia. Gauchismo quase gestual e autodeterminação rigorosa do pensamento relativizam-se mutuamente no discurso drummondiano: será esta a dinâmica de tantos de seus melhores poemas. ${ }^{269}$

Os metapoemas de A rosa do povo, como “O elefante” (entre tantos outros), se tomados como texto desprovido de contexto, permitem muitas abordagens, e inúmeras interpretações. Mas, quando situados em seu contexto literário (a coletânea), revelam uma pluralidade de situações (sua paradoxal coerência), cuja coesão é o lirismo (ele também paradoxal, porque o “individuum” é múltiplo, por inesgotáveis personae).

A coerência [do discurso drummondiano] se dá no interior dos textos $e$ no diálogo entre eles, com predominância ora da tonalidade mais confidencialmente lírica, ora da definição de um momento mais especulativo: em estado puro talvez não encontremos nunca o "timidíssimo" $e \quad o$ "inteligentíssimo" que Mário de Andrade tão certeiramente detectou como pólos de uma contradição feroz. Tais variações têm conseqüências evidentes para o humour e para a linguagem, compondo um leque amplo que vai do

\footnotetext{
267 Alusão ao último verso de "O elefante” (“Amanhã recomeço.”, v. 100)

268 Alusão aos versos de "O elefante” (“eu e meu elefante, / em que amo disfarçar-me.”, v. 89-90).

${ }^{269}$ Alcides VILLAÇA, "Um elefante de mentira e de verdade", in Lendo poetas brasileiros, p. 34.
} 
epigrama e da notação impulsiva à elegia e ao discurso reflexivo, da peça narrativa ou dramática ao testemunho algo pacificado do memorialista. ${ }^{270}$

A característica desse lirismo (gauche) é, na verdade, o metalirismo, que não se cansa de figurar a si próprio, e ressignificar-se, sob a perspectiva mitopoética da redenção de eu e mundo. "O elefante”, “Cidade prevista”, “Procura da poesia”, “Consideração do poema” e muitos outros poemas de A rosa do povo figuram a “poesia”, não como um objeto definível, mas como um processo. Para figurá-lo, a subjetividade lírica (a persona autoral) e a subjetividade leitora (o "público”, ou “povo”) “interseccionam-se” (na metalinguagem, nem sempre empática) para ressignificar (compor uma “obra” sobre) o “mundo” (o “meio”), “sentido” por uma mimese complexa (“percepção”) que se transfigura, segundo um “projeto” (ressignificase $)^{271}$. Como vimos, “Consideração do poema” enfatiza, no processo de significação figurado, o "significado", enquanto "Procura da poesia” atenta para o "significante”. “Cidade prevista”, ao figurar o processo poético de um terceiro modo, ressignifica o “mundo” (ou o "referente”) quando enuncia a “precariedade” do “canto” (do “signo”).

O poema "O elefante”, ao também figurar a "precariedade” do "signo poético" (que, não conseguindo "significar” nada para o "público”, desmonta as suas "formas significantes”),

... não alude à integridade dos mitos, mas à sua mais que problemática construção entre os alaridos e a reificação geral. Por que problemática? Porque o individualismo de onde ainda busquem os mitos nascer é ele mesmo a sua impossibilidade: a voz lírica é hoje antes agônica que solidária, e seu destino se transvia nas ruas surdas com multidões apressadas. Porque o sujeito moderno descentra-se entre a massificação e a utopia, sentindo-se muito

\footnotetext{
${ }^{270}$ Idem, ibidem, p. 34-35.

${ }^{271}$ Vejam-se os versos finais de "Consideração do poema”: “... tal uma lâmina, / o povo, meu poema, te atravessa." (v. 62-64).

Segundo Iumna SIMON, “A disposição sintática inusitada [desses versos], entrecortada por vírgulas, tece a rede circular da ambigüidade semântica. Os termos 'o povo' e 'meu poema' preenchem, simultaneamente, várias funções sintáticas: são agentes e objetos do processo verbal e ainda revezam-se nas funções vocativa e apositiva. (...)

Todos esses cruzamentos verificáveis no plano da sintaxe constituem-se, portanto, como o suporte de interações semânticas de ordem superior - 'povo' e 'poema' fundem-se num complexo global de significação que define o duplo e arriscado objetivo da 'viagem mortal': o 'canto' se quer atravessado pelo povo e quer atravessar o povo - como uma 'lâmina'. Poesia em 'busca dos outros', na senda daquilo que Octavio Paz considera como sendo o resumo de todas as imagens poéticas: 'Poema: búsqueda del tú'. No caso de A Rosa do Povo, um 'tu' plenamente identificado com o 'povo' - elemento constituinte do título da obra e invocado explicitamente em 'Consideração do poema'.

A 'viagem mortal' realiza-se, portanto, como perseguição constante desse 'tu' que seria, em última instância, a tentativa de resolução do antagonismo arte / vida - matriz dos demais conflitos e impasses enfrentados pela poesia moderna e que comparece em 'Consideração do Poema' (percorrendo toda a obra de 45) sob a forma explícita do binômio poema-povo...” (Drummond, uma poética do risco, p. 69-70)
} 
justificadamente gauche em ambas as instâncias. Porque a consciência individual vem mais e mais se afirmando enquanto ironia, para tentar manter distantes a ingenuidade que aliena e a adesão que embrutece... ${ }^{272}$

Sendo essa uma interpretação do poema pertinente, em que medida ela é válida também para toda a coletânea, no geral, e para outros metapoemas, em particular?

O lirismo de "O elefante", de fato, figura a "poesia" como um "personagem" que, incompleto, desintegra-se, já que o "autor" não encontra receptividade no "público". Diferentemente de "Cidade prevista", o "canto" denota o intento de afirmarse, muito embora o "mundo" seja "sentido", em ambos os poemas, como um "meio" hostil ao "canto". (Note-se, entretanto, que, no poema "O elefante", o "mundo", assim como o "personagem" gauche, é figurado, enquanto, em "Cidade prevista”, o "mundo" que se "canta” é o negativo do mundo "objetivo”, e não propriamente uma figura).

O tom, em ambos, difere. Em um, é eloqüente, e flerta com a "epopéia" (mas assume a forma de um apelo conativo que delega o "canto" para os seus "irmãos", "um dia, dentro em mil anos, / talvez mais... não tenho pressa”). No outro, o tom é alegórico, e aproxima-se da "elegia" (mas termina reafirmando o projeto de "fabricação do elefante": "amanhã recomeço"). Tanto a "epopéia" quanto o "lirismo", ambos precariamente interditos no "presente", projetam-se num "futuro", que, assim como qualquer outra figura metapoética, não tem, no real "extra-literário”, a sua existência imediata, mas sim na realidade simbólica do texto.

No poema "O elefante", o "recomeço" parece fadar o "poeta" à condição semsentido de Sísifo, o que é de fato a sua condição correspondente no "hoje" industrial da modernidade. Mas o "mundo enfastiado" (v. 27) da modernidade está em crise, "no campo de batalha" (v. 70), de maneira que o "amanhã" do poema tanto pode remeter ao "eterno retorno" do "trauma" (indicando a releitura de uma sempre mesma elegia) quanto pode remeter a um outro texto / contexto (o da "passagem da noite", o do "amanhecer",273).

A "O elefante", segue imediatamente o poema "Morte do leiteiro", e essa "passagem" marca a superação de um "amanhã recomeço" infinito (um "elefante" aparentemente fadado eternamente a " desmontar").

\footnotetext{
272 Alcides VILLAÇA, op. cit., p. 46-47.

273 As imagens da "passagem da noite" e do "amanhecer", presentes em diversos poemas de A rosa do povo, são, também, títulos de dois poemas.
} 
83. Da garrafa estilhaçada,

84. no ladrilho já sereno

85. escorre uma coisa espessa

86. que é leite, sangue... não sei.

87. Por entre objetos confusos,

88. mal redimidos da noite,

89. duas cores se procuram,

90. suavemente se tocam,

91. amorosamente se enlaçam,

92. formando um terceiro tom

93. a que chamamos aurora.

Diferentemente do que ocorre com o "elefante" (que parece condenado a sempre “desmontar”, quando for “já tarde da noite” no poema: v. 81), o "leite” da "garrafa estilhaçada” (derramado, na "madrugada”, junto com o "sangue” do "leiteiro", com quem o "poeta”, disfarçado de “narrador”, se identifica, ainda mais do que com o “elefante”) transfigura-se. Para tanto, o poema entrelaça, formalmente, três vozes na “trama narrativa” (a do "leiteiro”, a do "homem” e a do "leitor”, aproximadas pela voz do “narrador”), enquanto, em “O elefante”, a “voz (meta)lírica”, num tom alegórico, enuncia-se "precária”. Assim, a voz lírica, figurada em “O elefante” (que "é hoje antes agônica que solidária”, nas palavras de Villaça), difere da voz lírica de "Morte do leiteiro", disfarçada de "narrador”, e literalmente integrada a outros "elementos do discurso literário”, sob a primeira do plural.

Ao afirmar que “o realismo poético de Drummond não alude à integridade dos mitos, mas à sua mais que problemática construção entre os alaridos e a reificação geral”, Villaça aponta para uma dimensão fundamental do lirismo drummondiano, que de fato, como ele mesmo constatara, consegue captar o sem-sentido dum mundo com o qual é impossível o “individuum” identificar-se plenamente, muito embora o desejo mitopoético da completude faça com que outros níveis significantes do gauchismo não concedam a "palavra final” à persona poética de um ou de outro poema, ou ao seu significado parcial (denotativo). É por isso que entendemos que a “palavra final”, em $A$ rosa do povo, não deve ser concedida a "o elefante” (como persona poética) nem a "O elefante” (como “poema-síntese”274), mas ao “diálogo” entre o “interior do texto” e o

\footnotetext{
274 “Afora os leitores definitivamente seduzidos pelo universo integral da poesia drummondiana, há os de preferência tópica, não raro exclusivista: o poeta "participante" da Rosa do povo ou o atormentado investigador de Claro enigma - por exemplo - dão em alinhamento de gostos e opções contraditórios. Mas há poemas em que todos podem se encontrar, poemas de encruzilhada e síntese, como me parece ser o caso de "O elefante, de A rosa do povo (1945). Entre fábula e alegoria, confissão lírica e testemunho realista, afirmação e negação da mimese, esta peça é quase inapanhável nas sugestões em que se abre. Tem como
} 
contexto, em que há "predominância, ora da tonalidade mais confidencialmente lírica, ora da definição de um momento mais especulativo”, em que os significados são sempre dialogais.

Além das múltiplas “tonalidades”, percebemos na metapoesia a figuração de múltiplos "gêneros poéticos” (que, na metalinguagem, são, metonimicamente, aspectos da "epopéia”, da "lírica” etc.) e, mesmo, de aspectos de diversos "gêneros prosaicos" (como a “crônica”, o “manifesto”etc.). Mas, no processo significante das “inquietudes”, os diversos recursos literários (aspectos dos "gêneros", ou então os recursos fundamentais do poema, os elementos do discurso, entre outros), evidenciados como “objetos” do “canto” pelo distanciamento metalingüístico, acabam se “sujeitando” às necessidades da volição lírica, que, pelos recursos do gauchismo, transcende as dimensões autobiográficas do autor (sem, contudo, negá-las) e encaminham-se no sentido de integrar os outros sujeitos do discurso. E é nessa dimensão profunda do discurso poético que o "engajamento" se faz: não mais como "assunto", mas como elemento integrado, em termos viscerais, ao sistema simbólico e ao pensamento poético de A rosa do povo.

4

Quando se percebe que a consciência metalingüística é um fundamento em $A$ rosa do povo, torna-se possível abordar a sua dimensão significante sem perder de vista um dos seus significados principais, que é o envolvimento nas questões contemporâneas com fins transfiguradores. Essa dupla preocupação analítica (compreender os níveis da significação e do significado), entretanto, deve levar em conta o dinamismo dessa poética, que não admite abordagens unívocas (senão em termos provisórios e, portanto, restritos).

O princípio do “engajamento” se expressa pelo caráter dialogal da coletânea, numa multiplicidade vertiginosa de formas, o que, de resto, corresponde ao fator de sua

\footnotetext{
centro a relação entre o artista e o mundo moderno, pensada e concretamente figurada no percurso do animal terno e desajeitado, movido a esperança num tempo de indiferença." (Idem, ibidem, p. 35).

Embora concordemos com as teses do Autor, entendemos que a "síntese" da coletânea não está no poema em si, ou no seu tema ("a relação entre o artista e o mundo moderno"), mas na função que as sugestões formais metapoéticas assumem nos contextos intra e extra literário de $A$ rosa do povo.
} 
coerência, e que, de nenhum modo, contradiz a sua coesão lírica. Por sob diversos tons e personae, há o impulso da subjetividade poética em direção ao encontro com o mundo, e embora esse impulso invariavelmente constate a situação reificada do eu no mundo moderno, o seu significado último não é a mimese imediata da precariedade e do impasse, mas a sua denúncia e concomitante transfiguração. As manifestações desse caráter dialogal vêm expressas pela figuração de "falante" e "ouvinte" sob variadas situações interlocutórias, umas mais explícitas que outras, todas, entretanto, presididas pela escala da subjetividade lírica, que, pelo recurso do gauchismo, surge de maneira mais ou menos mediada.

A situação mais evidente, mas não única, de interlocução em $A$ rosa do povo é quando a figuração do diálogo recorre, explicitamente, às imagens de um "emissor” em “comunicação” com um “receptor”, momento em que há marcas explícitas de “eu” e “tu”. Em “Cidade prevista”, denota-se o “pedido” de um “cantor fracassado” aos “poetas”, seus contemporâneos, para que, em seu lugar, componham a "epopéia” de uma "cidade futura”, o que nos leva a desconfiar, no final das contas, que não se trata propriamente de “epopéia” e, tampouco, de “interlocução” com "poetas” de fato contemporâneos, mas de uma forma “metapoética” de transfigurar o presente pela “projeção” do desejo lírico, tornando-se o plano do enunciado mais retórico do que efetivo.

Nesse poema, a enunciação assume um tom epistolar, mas o plano imediato do discurso poético, pelas correlações significantes estabelecidas, transfiguram-se em significados mais complexos, de maneira que a subjetividade lírica, servindo-se de recursos metalíngüísticos, termina por metamorfosear a enunciada precariedade perceptiva (que remete mais ao “mundo", e às “formas” de "representá-lo”, do que à persona do “eu”) pela projeção volitiva (na qual a subjetividade lírica, por sob a(s) persona(e), se afirma sobre o mundo, figurado em negativo).

Outros poemas apresentam a estratégia retórica de um "eu” que se dirige a um “tu” através de algum “meio”, seja na forma de “carta”, seja na forma de "telegrama” (ou, ainda, sob a forma de “conversa”, mas que não deixa de explicitar suas “mediações”). Como todos esses poemas, cada qual a seu modo, praticam a metalinguagem (porque tratam os elementos do discurso como figuras, por sob as quais há a subjetividade gauche), invariavelmente há um distanciamento, embora sutil, por sob o pathos figuradamente elevado, o que se torna um recurso capaz de relativizar (quando não, de subverter), pelo adensamento lingüístico, a eloqüência, a plena 
identidade (ou plena alteridade) e, enfim, as características de um discurso apenas aparentemente “conativo” (em que a “comunicação” supostamente acarreta perda para a densidade do discurso, propriamente “poético”).

"Mário de Andrade desce aos infernos" e "Canto ao homem do povo Charlie Chaplin” são dois “cantares de amigo” 275 , em que há mimese de aspectos do estilo literário do artista e intelectual, no primeiro, e, no segundo, do estilo cinematográfico de "Charlie" (sobrepostos, portanto, o cineasta e a sua obra, representada por seu personagem mais popular). A identificação de A rosa do povo (na figura do personagem Gauche e na imagem "rosa do povo”) com as duas obras é tanta, porque formal, que o mero enunciado da “precariedade drummondiana”, contraposta à “eficiência” de ambos, relativiza-se e subverte-se, numa flagrante contradição entre os planos denotativo e conotativo.

A figura “autoral” de "Carlos Drummond de Andrade”276, como um “Outro”, dialoga com a figura "autoral” de "Charles Chaplin", sugerindo a "precariedade” da sua própria linguagem (“de ritmos elementares”: v. 6) no plano da enunciação. Mas, para além do enunciado verbal e do plano temático, o que há é a mimese ("pantomima”, v. 10) da linguagem cinematográfica (a retórica da imagem fotográfica em movimento) pelo discurso denso da poesia (com os seus recursos sonoros, rítmicos e imagéticos, “sobcolor de poema”, v. 12). Portanto, trata-se de dois universos estéticos radicalmente específicos, e, como tais, configurados, mas que se imbricam em questões a um tempo éticas (“artes não burguesas”, v. 197) e estéticas (“visitemos no escuro as imagens”, v. 32), e não pela verborragia do “acalanto burguês”(v. 21), ou pela “saudação dos devotos nem dos partidários" (v. 25). Na mimese, explicitada como tal, "Carlos” e "Charles”, com suas alteridades estéticas, convergem no duplo "Charlie”, eticamente um mesmo $^{277}$.

Bem como "Mário de Andrade desce aos infernos", em que as personae do “amigo extraordinário” (v. 28-29) multiplicam os "mais diversos brasis” (v. 39) na polissêmico-sintética “rosa do povo” (v. 47) (que ao mesmo tempo “despetala-se”, no

\footnotetext{
275 A expressão remete ao v. 35 de "Mário de Andrade desce aos infernos" e é, também, um pouco modificada, o título de uma seção da Antologia poética ("Cantar de amigos", p. 77-93).

${ }^{276}$ Esta "figura" aparece, como vimos, no poema "Últimos dias", v. 98.

277 Do "Charlie", anunciado no título, o personagem passa a ser denominado "Carlito", no último verso do poema. Vale dizer: depois de uma "tímida" aproximação inicial, que parece reforçar mais a alteridade do que a identidade (v. 1-12), a "pantomima" de trechos cinematográficos pela pluralidade de recursos poéticos cria uma tal proximidade entre os dois artistas que some por completo a sensação de alteridade, prevalecendo uma radical identidade entre os dois universos estéticos, marcada, inclusive, pela convergência ética. Diga-se, por fim, que "Carlito" era, também, o apelido familiar de Drummond (Cf. CANÇADO, op. cit., p. 31-54).
} 
plano contextual biográfico, mas "conserva o pudor da alva”, no plano textual bibliográfico", v. 48-49), também "Canto ao homem do povo Charlie Chaplin" multiplica o cineasta-cinematografia em diversos "papéis":

158. Colo teus pedaços. Unidade

159. estranha é a tua, em mundo assim pulverizado.

160. E nós, que a cada passo nos cobrimos

161. e nos despimos e nos mascaramos,

162. mal retemos em ti o mesmo homem,

$163 . \quad$ aprendiz

164. bombeiro

$165 . \quad$ caixeiro

$166 . \quad$ doceiro

167. emigrante

$168 . \quad$ forçado

169.

$170 . \quad$ noivo

171. patinador

172. soldado

$173 . \quad$ músico

174. peregrino

$175 . \quad$ artista de circo

176. marquês

$177 . \quad$ marinheiro

178. carregador de piano

, e o faz como que em resposta às "poucas existências”, enunciadas no ethos burguês de, por exemplo, “O medo” (“As existências são poucas: / carteiro, ditador, soldado.”, v. 4). De toda forma, é importante que tantas "possibilidades [ético-estéticas] existenciais" remetam a:

179. apenas sempre entretanto tu mesmo,

180. o que não está de acordo e é meigo,

181. o incapaz de propriedade, o pé

182. errante, a estrada

183. fugindo, o amigo

184. que desejaríamos reter

185. na chuva, no espelho, na memória

186. e todavia perdemos.

A figuração ambivalente de uma “existência múltipla”, que “apenas sempre entretanto" remete a um "mesmo homem”, identifica tanto as “artes não burguesas” de 
um homem-obra síntese d' “os brasileiros”278 (a "gente de pé-no-chão”, entre “Cézanne e Picasso"279) quanto “as artes não burguesas” de outro homem-obra síntese de “qualquer gente do mundo - inclusive os pequenos judeus / de bengalinha e chapéucoco, sapatos compridos, olhos melancólicos, / vagabundos que o mundo repeliu, mas zombam e vivem / nos filmes” ${ }^{\text {280 }}$ ). E essas duas figuras, coerentemente plurais, têm, no plano da forma, uma profunda identidade com o traço de “inquietudes”, que caracteriza a subjetividade gauche drummondiana, na medida em que a pluralidade (de personae, de tons e de espaços-tempos) é fator de coerência que não anula, antes reforça, a coesão lírica de um “individuum” (identitariamente múltiplo). Sob a aparência “epistolar”, é de "lirismo" que se trata, de um lirismo que recorre à metalinguagem como forma de tornar polissêmicos os elementos significantes, por meio de uma imagética especular.

5

Quanto à aparência de comunicação efusiva e eloqüente em, por exemplo, “Carta a Stalingrado”, cumpre observar que a subversão da escala “aporética” é, já no plano do enunciado, sugerida:

9. A poesia fugiu dos livros, agora está nos jornais.

10. Os telegramas de Moscou repetem Homero.

11. Mas Homero é velho. Os telegramas cantam um mundo novo

12. que nós, na escuridão, ignorávamos.

13. Fomos encontrá-lo em ti, cidade destruída,

14. na paz de tuas ruas mortas mas não conformadas,

15. no teu arquejo de vida mais forte que o estouro das bombas,

16. na tua fria vontade de resistir.

A impressão que se tem, num primeiro momento, é que se trata de um "canto" efusivo, loquaz, e que, portanto, não há entraves de nenhuma natureza à exaltação do pathos, à livre comunicação e à participação política imediata da subjetividade nos eventos. Visto mais atentamente, contudo, o “canto”, “endereçado” à “cidade” (que

278 "Canto ao homem do povo Charlie Chaplin", v. 13

279 "Mário de Andrade desce aos infernos" (v. 56-57).

280 "Canto ao homem do povo Charlie Chaplin", v. 15-18. 
apenas aparentemente é a representação “épica” dos seus habitantes ${ }^{281}$ ) explicita-se, ainda que sutilmente, como "leitura de jornais”, e não como participação direta do “cantor” na "Batalha”. E os “jornais”, por sua vez, "noticiam” o que lhes chega, não através do relato de seus “correspondentes”, mas por “telegramas”.

Com isso, a produção de imagens eloqüentes sobre a Resistência soviética remete, antes, à “imaginação poética” do "cantor” por sobre o discurso lacunar, e “mediado”, dos “telegramas”, o que, de resto, fica claro, em outros poemas da "lírica de guerra”, pelas paradoxais elipses do subseqüente “Telegrama de Moscou”282, e pelo discurso "precário" de "Mas viveremos", "Visão 1944” e "Com o russo em Berlim" (que, embora explícito, sugere o caráter interdito da situação brasileira, e mundial, sob governos filo-fascistas ${ }^{283}$ ). Nesses poemas, a “informação” figura-se interdita, e esse “discurso”, no plano semântico (quando não sintático), é eivado de lacunas, num contraponto evidente à sugestão tonal de “comunicação epistolar”. O sentido paradoxal dessa interlocução é figurar uma subjetividade cuja situação (a um tempo objetiva e subjetiva) caracteriza-se como interdita. O seu sentido conotativo, entretanto, é transfigurá-la.

O antídoto contra a eloqüência, em $A$ rosa do povo (loquacidade que, em nenhum poema, se cumpre de maneira integral, senão provisória), explicita-se sobretudo em “América”. O poema figura a "tímida conversa de amor” entre um "homem pequenino à beira de um rio" (v. 1-7) e o “continente”, personificado numa forma feminina, aparentemente “colossal”, mas que, no entanto, resulta da justaposição de fragmentos imagéticos e estilísticos ("esses pedaços de ti, América, partiram-se na minha mão”, v. 109).

\footnotetext{
281 O sugerido "heroísmo" dos cidadãos de Stalingrado apenas aparentemente contradiz a colocação "epistolar" de "Canto ao homem do povo Charlie Chaplin" (no v. 8: "e a opressão é detestada, se bem que o heroísmo se banhe em ironia"). Esses habitantes "todos morreram, estropiaram-se, os últimos defendem pedaços negros de parede" (v. 38): não transcendem, portanto, a condição "humilde" de "simples mortais", nem as necessidades "menores" do cotidiano. Se há transcendência de natureza heróica, ela se personifica, antes, na "cidade" ("mas a vida em ti é prodigiosa e pulula como insetos ao sol, / ó minha louca Stalingrado!", v. 39-40). Ainda assim, trata-se de uma imagem "dionisíaca”, e não "olímpica" ("A tamanha distância procuro, indago, cheiro destroços sangrentos, / apalpo as formas desmanteladas de teu corpo, / caminho solitariamente em tuas ruas onde há mãos soltas e relógios partidos, / sinto-te como uma criatura humana, e que és tu, Stalingrado, senão isto? / Uma criatura que não quer morrer e combate, / contra o céu, a água, o metal, a criatura combate, / contra milhões de braços e engenhos mecânicos a criatura combate, / contra o frio, a fome, a noite, contra a morte a criatura combate, / e vence.”, v. 41-49).

${ }^{282}$ Nos dois primeiros versos desse poema, cabe ao leitor operar, mentalmente, a construção de sentido, obstáculo criado pela característica sintaticamente incompleta dos referidos versos. A esse respeito, ver o cap. 4.

${ }^{283}$ Tratamos dessa questão também no cap. 4.
} 
O impulso erótico desse “amor”, sem ultrapassar a marca lírica da experiência “objetivamente” cotidiana do "homem pequenino”, “solitário”, “interiorano”, logra alcançar (como "projeção metapoética”) a dimensão múltipla e coletiva (mas nunca "heróica”) de um espaço-tempo “despetrarquizado"284 (ainda que “visto” sob o prisma da volição subjetiva). Esse “encontro amoroso”, efetuado pelo "meio de conhecimento" (v. 134) e pela “mensagem”, é uma espécie de “precária síntese”285 da volição lírica, a “metamorfosear” sua própria “solidão” e a "solidão de milhões de corpos nas casas, nas minas, no ar” (v. 129), em “solidariedade” (v. 40-47, v. 130-133).

Entre a(s) perspectiva(s) “continental(is)” e a escala da "timidez” subjetiva, a “conversa” termina por imprimir um caráter ciclotímico ao poema longo (142v.), na medida em que há uma oscilação entre a condição espaço-temporal isolada e uma perspectiva mais ampla, cujo pano de fundo sugere uma bricolagem de elementos da “prosopopéia” (a antropomorfização do continente), da “epopéia” (a narrativa, a partir de um presente, das origens míticas pretéritas: v. 53-98), da "saga” (a narrativa da formação de “cidades”: v. 99-111), da "autobiografia” (o aprendizado em Itabira, v. 2147), da “canção” (as “violas [que] sobem até à lua”: v. 48-98), da “crônica” (a execução da pena de morte: v. 130-133) e de um sem-número de dicções fragmentárias, justapostas pela subjetividade lírica.

A “timidez” enunciada não impede a multiplicação do eu lírico por diversas perspectivas. Do "homem pequenino à beira de um rio" (v. 2), a passar "a mão na cabeça que vai embranquecer” (v. 8), ao "sorriso na face de um homem calado" (imagem-síntese d' "esses homens [americanos que] estão silenciosos mas sorriem de tanto sofrimento dominado”, v. 140-142), nota-se a metamorfose da “solidão” (condição subjetiva / objetiva do eu e de diversos outros sujeitos) em "solidariedade”.

A “conversa” é toda pontuada por "meios de conhecimento" os mais diversos: “galos” (v. 5), “velhos amigos” (v. 17), “versos” (v. 25), “mapas” (v. 31, v. 99), “violas” (v. 52), “canções” (v. 53-98, v. 121), “rádio, cabogramas, vitrolas e tiros” (v. 116-117), “jornal” (v. 125), “carta” (v. 131); todos esses "elementos de mediação” figuram aspectos da própria “mensagem”. O debruçar da "linguagem” sobre si própria serve como contraponto reflexivo (disfarçado de "timidez”) à empatia imediata. Para

\footnotetext{
${ }^{284}$ Expressão tomada a Merquior e que significa a operação poética drummondiana, empenhada em romper com formas de idealização e de figuração sublime, especialmente evidenciada em "O mito". Sobre o poema, o crítico afirma: "Mulher atlética e positiva, Fulana destrói o mito do amor petrarquista. (...) Em $A$ Rosa do Povo, pois, o lirismo crítico de Drummond tende a recusar a ética da paixão. Este antipetrarquismo radical está nas antípodas do "amour fou" pregado por Breton." (Verso universo em Drummond, p. 88-89)

285 Expressão tomada a "Nosso tempo" (v. 11-13).
} 
além da condição precária (“Há vozes no rádio e no interior das árvores, / cabogramas, vitrolas e tiros. Que barulho na noite, / que solidão! // Esta solidão da América... ermo e cidade grande se espreitando”, v. 116-120), ou do tom laudatório (“Ah, por que tocar em cordilheiras e oceanos! / Sou tão pequeno (sou apenas um homem) / e verdadeiramente só conheço minha terra natal, / dois ou três bois, o caminho da roça, / alguns versos que li há tempos, alguns rostos que contemplei. / Nada conto do ar e da água, do mineral e da folha, / ignoro profundamente a natureza humana / e acho que não devia falar nessas coisas.”, v. 21-28), o que há é um prisma integrativo por sob um “tom menor":

48. $\quad$ Ainda bem que a noite baixou: é mais simples conversar à noite.

49. Muitas palavras já nem precisam ser ditas.

50. Há o indistinto mover de lábios no galpão, há sobretudo silêncio, 51. certo cheiro de erva, menos dureza nas coisas,

52. violas sobem até à lua, e elas cantam melhor do que eu.

“À beira de um rio”, a "conversa” suprime o tom confessional sem suprimir a escala lírica do vivido (a "vida interiorana” de quem sabe “apenas que é noite porque me chamam de casa”, e vê “que amanheceu porque os galos cantaram”: v. 4-5), nem, tampouco, abandonar a “conversação”, mas assumindo o “disfarce” dos recursos não exclusivamente “verbais”. De fato, a “conversa” comporta outros elementos que não os da linearidade discursiva, servindo-se de “gestos” (v. 8-14, 130-133), “prosódias” (v. 13, 21, 38, 46), “lendas” (v. 53-98, 99-115) e outros elementos que tornam complexas as inter-relações significantes e transcendem o plano imediato do enunciado. Para além do exotismo de uma natureza hiperbólica (v. 112-113) e do regionalismo interdito (v. 21-28, 99-111), a poética figurada “escava” a “memória” de seu próprio espaço-tempo “solitário”, e termina por transfigurá-lo em “solidariedade”, recusando-se, contudo, à eloqüência.

29. Uma rua começa em Itabira, que vai dar no meu coração.

30. Nessa rua passam meus pais, meus tios, a preta que me criou.

31. Passa também uma escola - o mapa -, o mundo de todas as cores.

32. Sei que há países roxos, ilhas brancas, promontórios azuis.

33. A terra é mais colorida do que redonda, os nomes gravam-se

34. em amarelo, em vermelho, em preto, no fundo cinza da infância.

35. América, muitas vezes viajei nas tuas tintas.

36. Sempre me perdia, não era fácil voltar.

37. O navio estava na sala.

38. Como rodava! 
39. Uma rua começa em Itabira, que vai dar em qualquer ponto da terra.

40. Nessa rua passam chineses, índios, negros, mexicanos, turcos, uruguaios.

41. Seus passos urgentes ressoam na pedra,

42. ressoam em mim.

43. Pisados por todos, como sorrir, pedir que sejam felizes?

44. Sou apenas uma rua

45. na cidadezinha de Minas,

46. humilde caminho de América.

Trata-se, através da metalinguagem, de um alcance imagético sobre a condição “objetiva” do continente americano, transfigurada, entretanto, não pelo “exótico”, nem pelo “fantástico", não pelo "nativismo”, nem pelo “despaisamento”, mas por um “sentimento - íntimo - do mundo”, sob a escala da experiência lírica, figurada num lugar e num tempo determinados, sem, contudo, resignar-se a eles. Não apenas o discurso torna-se mais denso, com múltiplas possibilidades semânticas; a mitopoética “Itabira”, como metonímia de "Brasil”, de “América”, de “China / Índia / África / Turquia”, logra superar a condição “objetiva” do "sentimento da mata e da ilha” (e, por que não dizer, de “sentimento de Tordesilhas”?).

De todos os poemas em que a interlocução explicita-se pela presença de um “eu” e um "tu” marcados, "Como um presente” talvez seja o momento de A rosa do povo em que há a mais intensa elevação do pathos. Nele, a imagem da "escavação das raízes” (o "projeto de fuga”286, denotativamente impossível, da identidade patriarcal “em cadeia”: v. 59-66), desenvolve diversas tentativas discursivas de refletir sobre as “origens” da identidade gauche (que se quer transfigurar em alteridade, mas que acaba por transfigurar aspectos do próprio patriarcado ${ }^{287}$ ). Apenas aparentemente, trata-se de uma interlocução “direta” com o "Patriarca”, quando, na verdade, os recursos metalingüísticos explicitam não se tratar, propriamente, de uma "longa conversa”, mas de uma produção de significados pela “exumação” simbólica do “Coronel”, e dessa

\footnotetext{
286 Esta expressão remete ao v. 11 do poema "Edifício São Borja" ("projeto de fuga ao Chile"), sujo significado aproximamos da problemática de poemas diversos (dentre os quais, "Como um presente").

${ }^{287}$ Tratamos dessa problemática no cap. 4.
} 
construção mnemônica resulta uma agressão ao poder patriarcal, disfarçada de "pedido de perdão” (v. 84) e de “comunhão afetiva” (v. 89-92). ${ }^{288}$

O significado político desse ato simbólico é enorme, numa conjuntura em que o governo ditatorial liderado por Vargas, embora tenha recebido apoio de setores que combatiam as oligarquias locais, terminou por reafirmar o coronelismo, absorvendo estrategicamente as elites economicamente empobrecidas nas funções burocráticas do aparelho estatal ${ }^{289}$ e estabelecendo uma relação direta entre o poder pessoal dos oligarcas e o poder centralizado na esfera do governo federal ${ }^{290}$.

A interlocução entre o eu Gauche e o Patriarcado, que na verdade são aspectos de uma contradição brutal, mas indissociável (identidade / alteridade), não se restringe a “Como um presente” (embora a figuração do “eu” como Filho, do “tu” como Pai e duma "interlocução" denotativamente imaginária restrinja-se a apenas esse poema). É tentador estabelecer uma espécie de “bloco da escavação” duma subjetividade estigmatizada pelo patriarcado, e que se desespera por aprofundar a inteligência dessa (literalmente) "radicalidade” afetiva em direção à solidariedade com outros povos (a uma alteridade, em suma), na medida em que há nada menos que onze poemas consecutivos a tratar da experiência “autobiográfica” do Gauche.

“Noite na repartição”, como sabemos, figura, num tom cômico-paródico, o estraçalhamento da subjetividade lírica de um "burocrata”, sugerida "dramaticamente” (isto é, pela forma parodicamente “dramatúrgica” e conotativamente despersonalizante) nos diálogos entre o “OFICIAL ADMINISTRATIVO” e os objetos antropomórficos do “escritório”.

O poema seguinte, "Morte no avião" é a narrativa, sob fluxo de consciência, do cotidiano de um pequeno burguês, funcionário em algum "escritório”, ou "repartição" (v. 21-26, 40-44), certamente incumbido de responsabilidades administrativas (v. 4244), e que, sem suspeitar da fatalidade do seu destino próximo (a despeito de alguns presságios), experimenta, em detalhes, o dia-a-dia comezinho sob o tempo tripartite (o tempo social capitalista, fragmentado segundo o ethos da "obrigatoriedade": cuidados

\footnotetext{
288 Pensamos, portanto, diferentemente de José Guilherme MERQUIOR (op. cit., p. 92-93), para quem "Talvez a dimensão objetiva e realista sobre o círculo familiar derive da atitude ambivalente de Drummond, nessa época, em relação a essa instituição; com efeito, de um lado, ele não deixa de pôr em questão o sentido humano da família e do amor que ela nos inspira (...) por outro lado, não se engana com as idealizações da memória, sabendo muito bem o que há de ilusório em toda 'idade de ouro' do passado. (...) No entanto, a lembrança é reconciliação. As confissões de amor filial são uma tardia carícia, uma efusão póstuma apagando o gosto amargo das disputas, das revoltas, dos despotismos, da incompreensão mútua."

${ }^{289}$ Cf. Sérgio MICELI, Intelectuais e classe dirigente no Brasil.

${ }^{290}$ Eli DINIZ, “O Estado Novo: estrutura de poder, relações de classe”, in: Bóris FAUSTO (org.), História Geral da Civilização Brasileira, III, Vol. 3.
} 
pessoais e trabalho, e da sua complementar "gratuidade": tempo de descanso, sobre o qual refletimos, no capítulo 5). Assim, a “fábula” do cotidiano (em "Noite na repartição”) desdobra-se no “drama” do cotidiano ${ }^{291}$ (em “Morte no avião”: note-se o paralelismo também nos títulos).

Esse “ensaio sobre a morte” (que é “Morte no avião”) desdobra-se, por sua vez, no subseqüente "Desfile” (também um "ensaio sobre a morte”), em que o "luto” pelo “dia findo", figurado na forma de fluxo de consciência, termina sobreposto ao "luto" pela própria experiência pregressa. A consciência lírica objetiva-se, e o “eu” narra a um "tu” (que, na verdade, é um aspecto dele próprio) a sua experiência biográfica. A realização literária dessa “consciência”, a “desfilar”, objetivada, para o próprio eu lírico, figura, "formalmente", uma "construção mnemônica”, servindo-se da sugestão “métrica” duma forma bastante “memorável” (são sessenta versos em redondilha maior).
1. O rosto no travesseiro,
2. escuto o tempo fluindo
3. no mais completo silêncio.
4. Como remédio entornado
5. em camisa de doente;
6. como dedo na penugem
7. de braço de namorada;
8. como vento no cabelo
9. fluindo: fiquei mais moço.
10. Já não tenho cicatriz.
11. Vejo-me em outra cidade.
12. Sem mar nem derivativo,
13. o corpo era bem pequeno
14. para tanta insubmissão.
15. E tento fazer poesia,
16. queimar casas, me esbaldar,
17. nada resolve: mas tudo
18. se resolveu em dez anos
19. (memórias do smoking preto)
20. O tempo fluindo: passos
21. de borracha no tapete,
22. lamber de língua de cão
23. na face: o tempo fluindo.

291 A expressão "drama do cotidiano" foi tomada a Merquior, que a emprega para conceituar os poemas, como "Caso do vestido", em que a temporalidade figurada é a do dia-a-dia. "Encontram-se, com efeito, em $A$ Rosa do Povo textos sobre o drama do cotidiano cujo estilo é fundamentalmente diferente da Stilmischung que vimos atuando em, por exemplo, ‘A flor e a náusea', 'Nosso tempo' ou 'O mito'. Entre esses títulos, dois se tornaram (a justo título) clássicos na moderna literatura brasileira. O primeiro é 'Morte do leiteiro' (...) O outro clássico do 'drama do cotidiano', 'Caso do vestido', é menos 'popular' que rústico'." José Guilherme MERQUIOR, op. cit., p. 109-110) 
24. Tão frágil me sinto agora.

25. A montanha do colégio.

26. Colunas de ar fugiam

27. das bocas, na cerração.

28. Estou perdido na névoa

29. na ausência, no ardor contido

30. O mundo me chega em cartas.

31. A guerra, a gripe espanhola,

32. descoberta do dinheiro,

33. primeira calça comprida,

34. sulco de prata do Halley,

35. despenhadeiro da infância.

36. Mais longe, mais baixo vejo

37. uma estátua de menino

38. ou um menino afogado.

39. Mais nada: o tempo fluiu.

40. No quarto em forma de túnel

41. a luz veio sub-reptícia.

42. Passo a mão na minha barba.

43. Cresceu. Tenho cicatriz.

44. E tenho mãos experientes.

45. Tenho calças experientes

46. Tenho sinais combinados.

47. Se eu morrer, morre comigo

48. um certo modo de ver.

49. Tudo foi prêmio do tempo

50. e no tempo se converte.

51. Pressinto que ele ainda flui.

52. Como sangue, talvez água

53. de rio sem correnteza.

54. Como planta que se alonga

55. enquanto estamos dormindo.

56. Vinte anos ou pouco mais,

57. tudo estará terminado.

58. O tempo fluiu sem dor.

59. O rosto no travesseiro,

60. fecho os olhos, para ensaio.

Que este poema seja a possibilidade cotidiana de o sujeito lírico evadir-se da “temporalidade do obrigatório” pela “gratuidade” (“sem préstimo, é verdade”,292) da memória e do auto-conhecimento, isso não impede (antes, pressupõe) a transfiguração do “tempo presente” em direção a outras temporalidades, as quais, entretanto, são dimensões transcendentes, mas que não deixam de ser contemporâneas, na medida em que a evocação de aspectos do passado só se faz a partir de interesses e condições presentes. A esse respeito, a “outra cidade, sem mar nem derivativo” é o “não-lugar”,

292 Menção aos v. 53-54 de "Versos à boca da noite" (o penúltimo poema do "bloco da escavação"). 
negativamente visto a partir do "lugar"; em outras palavras: o seu lugar "objetivo" imprime a marca nos lugares "subjetivos", por meio da "memória”, entendida como a reconstrução de fragmentos do vivido a partir do presente. O espaço, pela ótica da apropriação subjetiva, é, então, um campo de projeções metafóricas, isto é, de transferências e (re)combinações de significados entre eu e mundo. ${ }^{293}$

O presente da “maturidade” percorre todo A rosa do povo; ele é o tempo-espaço a partir do qual o Gauche se exprime, seja para constatar o cotidiano reificado, seja para transfigurar essa temporalidade interdita pela linguagem (meta)poética, que a torna polissêmica. Nesses termos, o poema “Desfile”, especialmente os v. 1-30, 20-23 e 3960, é particularmente significativo de toda a obra.

Por diversos outros poemas, há traços autobiográficos do Gauche ${ }^{294}$, mas, em "Desfile”, eles se figuram mais evidentes. Considerando-se a biografia do poeta, as “insubmissões” dos v. 11-19, 24-38 tornam-se facilmente reconhecíveis. Entre todas, a mais marcante talvez tenha sido o questionamento ao professor de português do Colégio Anchieta, de padres jesuítas, em Nova Friburgo, punido com um conceito desfavorável em "comportamento", a que o então adolescente retrucou com uma carta, que, por sua vez, provocou uma punição ainda maior: a expulsão do colégio por “insubordinação mental"295. Mas igualmente marcantes foram os desafios ao "Patriarca" (ou “Coronel”,296), sob a forma, denominada pelo companheiro Pedro Nava, das “russificações”297. De todo modo, esse conhecimento biográfico não se faz necessário para a fruição do poema, uma vez que, em A rosa do povo, vale notar que a “autobiografia” também é válida como "heterobiografia”. 298

\footnotetext{
293 Michel de CERTEAU, op. cit., p. 169-191.

294 Veja-se o "menino de 1918" (v. 30-31 de “A flor e a náusea”), a quem "chamavam anarquista”, provável alusão autobiográfica ao episódio traumatizante do histórico escolar de Drummond.

${ }^{295}$ CANÇADO, op. cit., p. 68-70.

${ }^{296}$ Expressão tomada a "Como um presente", vejam-se os v.37-43: "Vejo, no rio, uma canoa, / nela três homens. / 'Inda que mal pergunte, o Coronel sabe nadar? / Porque esta canoa, louvado Deus, pode virar, / e sua criação nunca mais que o senhor há de encontrar.' / Tua mão saca do bolso uma coisa. Tua voz vai à frente. / 'Coronel, me desculpe, não se pode caçoar?' ". Sob estes versos-disfarces, bem caberia a face "insubmissa" do Gauche, a provocar a autoridade do Patriarca.

297 "Mesmo com as provocações de um Drummond jacobino e mal entrado nos vinte anos - como, por exemplo, a peça ainda fumegante do bonde incendiado por ele, Pedro Nava e Milton Campos, em 1921, e colocada como uma dinamite diante do seu pai na mesa de jantar -, Carlos De Paula Andrade sempre silenciou.

Carlos Drummond de Andrade nunca deixou de empalidecer quando mais tarde se lembrava dessa cena: ele veio a perceber que, mais do que uma provocação, uma 'russificação' (como Nava se referia às ações do grupo), na verdade ele estava era enfiando o braço no buraco do inconsciente, do infinitamente afastado, do atemporal - e que o silêncio que subia dali gelava." (CANÇADO, op. cit., p. 27-28).

298 Segundo Chantal CASTELLI, "Observamos, nos poemas de Boitempo, que ora o mundo itabirano acontece no 'interior' do poeta, através da narração de casos ocorridos com ele, ora o poeta coloca a si mesmo como parte do mundo, destacando o quadro social e cultural de sua infância e primeira juventude, através de seu
} 
"Desfile” aponta uma dimensão fundamental em A rosa do povo: a dimensão individual. Terceiro poema do "bloco da escavação (que, por sua vez, precede a "lírica de guerra” e sucede os poemas, entre “engajados” e “culposos”, pós-“fechamento do discurso à comunicação”), ele aponta para uma “participação política” que, de nenhum modo, quer apagar a individualidade para atingir um outro suposto “pólo”, o do “engajamento”, nem, muito menos, romper com o "hermetismo do discurso poético”, ou com o "prosaísmo do discurso participante”. A sua "insubmissão infantil” reafirma-se no "presente interdito", neste e também em outro poema do "bloco da escavação" (“Idade madura”):

55. Ninguém me fará calar, gritarei sempre

56. que se abafe um prazer, apontarei os desanimados,

57. negociarei em voz baixa com os conspiradores,

58. transmitirei recados que não se ousa dar nem receber,

59. serei, no circo, o palhaço,

60. serei médico, faca de pão, remédio, toalha,

61. serei bonde, barco, loja de calçados, igreja, enxovia,

62. Serei as coisas mais ordinárias e humanas, e também as excepcionais:

63. tudo depende da hora

64. e de certa inclinação feérica,

65. viva em mim qual um inseto.

Pelo visto, a condição interdita do “inseto” também é eficaz para reafirmar a “insubmissão" diante de quaisquer tentativas totalitárias: sejam aquelas impostas pela “politização do cotidiano pelo Estado e / ou pelo negócio”, sejam aquelas impostas pela necessidade do "heroísmo":

olhar distanciado e arguto. O que evidencia essa duplicidade nos poemas do livro é o uso indiferente da primeira e da terceira pessoa (...) As denominações 'eu' ou 'o menino' alternam-se nos poemas, e designam um mesmo indivíduo: ora particularizado, personalizado; ora generalizado, e mais a indicação da existência dos outros, da sociedade em que vive. É então que 'a experiência pessoal se confunde com a observação do mundo e a autobiografia se torna heterobiografia, história simultânea dos outros e da sociedade; sem sacrificar o cunho individual, filtro de tudo, o Narrador poético dá existência ao mundo de Minas no começo do século'." (Chantal CASTELLI, Lembranças em conflito, p. 7)

A observação do ensaio "Poesia e ficção na autobiografia", de Antonio CANDIDO (in $A$ Educação pela noite \&o outros ensaios), ampliada por Castelli, não deixa, em alguma medida, de ser válida também em $A$ rosa do povo, ainda que a observação dos autores sobre a impossibilidade da efetiva distinção entre o eu lírico e o autor afirme-se válida apenas "para este tipo de lírica ou memorialística, 'que supera francamente o sujeitonarrador para se concentrar poeticamente no objeto e, de torna-viagem, ver o sujeito como criação - e por isso empregamos também essas duas denominações ["recordação" e "invenção", aspectos presentes, em caráter de simultaneidade, em Boitempo, o que permite uma abordagem válida tanto em termos de "memória" quanto "ficcionais"] ao longo de nosso trabalho." (CASTELLI, op. cit., p. 2) Ainda que não haja propriamente "distância narrativa" entre o tempo da "maturidade gauche", em A rosa do povo, e a sua "memória" (metapoeticamente construída), de fato há, graças aos recursos dramáticos do gauchismo, objetivação de conteúdos líricos, de natureza autobiográfica, mas ampliada pela persona, que não é propriamente a do autor, e sob a qual também cabem outros sujeitos do discurso, como o "tu". 
22. De longe vieram chamar-me.

23. Havia fogo na mata.

24. Nada pude fazer,

25. nem tinha vontade.

26. Toda a água que possuía

27. irrigava jardins particulares

28. de atletas retirados, freiras surdas, funcionários demitidos.

29. Nisso vieram os pássaros,

30. rubros, sufocados, sem canto,

31. e pousaram a esmo.

32. Todos se transformando em pedra.

33. Já não sinto piedade.

34. Antes de mim outros poetas,

35. depois de mim outros e outros

36. estão cantando a morte e a prisão.

37. Moças fatigadas se entregam, soldados se matam

38. no centro da cidade vencida.

39. Resisto e penso

40. numa terra enfim despojada de plantas inúteis,

41. num país extraordinário, nu e terno,

42. qualquer coisa de melodioso,

43. não obstante mudo,

44. além dos desertos onde passam tropas, dos morros

45. onde alguém colocou bandeiras com enigmas,

46. e resolvo embriagar-me.

47. Já não dirão que estou resignado

48. e perdi os melhores dias.

49. Dentro de mim, bem no fundo,

50. há reservas colossais de tempo,

51. futuro, pós-futuro, pretérito,

52. há domingos, regatas, procissões,

53. há mitos proletários, condutos subterrâneos,

54. janelas em febre, massas de água salgada, meditação e sarcasmo.

Ao que parece, o Gauche, a despeito de tomar partido da Resistência soviética (a partir de um momento historicamente preciso: a Batalha de Stalingrado), está mais para o “menino de 1918” (“a que chamavam anarquista”299) que para um militante propriamente “comunista” (ou "marxista-leninista”). De todo modo, o individualismo exacerbado não impede o “engajamento”, sendo, antes, a sua pré-condição. É a partir dessa "solidão" necessária que se faz possível a "solidariedade”.

\footnotetext{
${ }^{299}$ Menção ao v. 31 de “A flor e a náusea” (“Ao menino de 1918 chamavam anarquista.”).
} 
Da condição “solitária”, nasce, em "Desfile”, mais um “ensaio"300 sobre a condição “finita” da existência humana (além do anterior "Morte no avião”). Não por acaso, a intensidade do pathos, alcançada nesses "ensaios”, leva a que, no próximo poema (“Consolo na praia”), o “eu” transforme-se num “tu” que "está nu na areia, no vento...”, e que não recebe nenhum “consolo na praia”, senão na forma de ironia (tão ácida, “desconsoladora”, que beira o "sarcasmo” de “Idade madura”: v. 54).

"Retrato de família” é uma interlocução entre o Gauche "maduro" e a sua memória “familiar”, figurada como "retrato”. Ao inquirir a(s) “imagem(ns)”, apenas aparentemente estática(s), do "retrato", as suas "figuras” ganham movimento, numa imagética de sabor surrealista que reforça a construção da memória a partir do tempoespaço presente.

A “escavação" obsessiva e grotesca da memória pessoal intensifica-se em “Interpretação de dezembro”, poema em que o “menino” (assim, em terceira pessoa: v. 1, 83-86) sobrepõe-se ao "rosto judaico" da imagem de Cristo (é Natal no passadopresente do poema, temporalidade ambivalente à qual sobrepõe-se uma terceira: a conjuntura do anti-semita governo Vargas ${ }^{301}$ ).

62. A cabana oca

63. na terra sem música.

64. O silêncio interessado

65. no país das formigas.

66. Sono de lagartos

67. que não ouvem o sino.

68. Conversas de peixes

69. sobre coisas líquidas.

70. São casos de aranha

71. em luta com mosquitos.

72. Manchas na madeira

73. cortada e apodrecida.

74. Usura da pedra

75. em lento solilóquio.

76. A mina de mica

77. e esse caramujo.

78. A noite natural

79. e não encantada.

80. Algo irredutível

81. ao sopro das lendas

82. mas incorporado

300 Menção ao v. 60 de "Desfile" ("fecho os olhos, para ensaio").

${ }^{301}$ Cf. Maria Luíza TUCCI CARNEIRO, O anti-semitismo na Era Vargas. A respeito da experiência pessoal de Drummond com o anti-semitismo varguista, cf. CANÇADO, "O anjo torto de Praga", op. cit., p. 169-176. 
83. ao coração do mito.

84. É o menino em nós

85. ou fora de nós

86. recolhendo o mito.

Situado no contexto do "bloco" e da coletânea (e, ainda, da conjuntura ditatorial) a que pertence, "Interpretação de dezembro", com o seu aparente distanciamento gauche, transforma-se num poema com pathos intenso, o qual vem a explicitar-se, no grau mais exaltado entre todos os poemas da coletânea, no seguinte "Como um presente". Como vimos, a interlocução entre o "eu” e a sua "experiência familiar", provinciana (impressa a ferro no psiquismo gauche pelo patriarcalismo), assume a forma figurada de um "eu” e um "tu”, mediados pelo “discurso" (metalinguagem). A figuração da exumação simbólica, sob comoção, desdobra-se no posterior "Rua da madrugada” (“A chuva pingando / desenterrou meu pai.”, v. 1-2) já sem interlocução evidente, e num tom distanciado, empregando formas nominais (nos verbos: v. 14, 18, 20-23, 27, 29, e nas frases: v. 32-39, 46-59).

De “Idade madura" a "Versos à boca da noite", o individualismo "da maturidade” exacerba-se (primeiro, num tom irritado, depois, num tom elegíaco), para concluir (“No País dos Andrades”), com um “aceno definitivo” à alteridade ${ }^{302}$ :

16. Adeus, vermelho

17. (viajarei) cobertor de meu pai.

No "bloco da escavação", o tom, entre o “memorialismo" e o “confessionalismo” gauche, acentua, a um tempo, o individualismo radical (a “escavação das raízes” autobiográficas) e a transfiguração do patriarcalismo (a “escavação das raízes” auto / heterobiográficas), e esses significados, sob a imagem da (re)construção mnemônica na maturidade, figuram-se por um uso sistemático de

302 Considerando-se o percurso no "bloco da escavação", o adeus à identidade provinciana e o aceno à alteridade soa definitivo, o que parece se confirmar na subseqüente "lírica de guerra", e nos três poemas que encerram $A$ rosa do povo ("Os últimos dias", "Mário de Andrade desce aos infernos" e "Canto ao homem do povo Charlie Chaplin”). 
recursos metalingüísticos. Dessa maneira, a subjetividade politiza-se (transfigurando a totalitária politização da intimidade subjetiva).

Preocupações de natureza “prosaica"303 infiltram-se na poética de $A$ rosa do povo, tornando-a temático-formalmente plural, e reforçando (sob uma aparente desfiguração) o lirismo. O “poético” e o "lírico”, enunciados (figuradamente) como “precários”, desfiguram-se, e, enriquecidos pela ressignificação metalingüística, radicalizam a densidade do seu discurso "participante".

Isso também se pode perceber pelo cruzamento entre a "prosa" e a "poesia" drummondianas, que se faz pertinente. Em Confissões de Minas (escrito entre 19321943 e publicado em 1944), algumas idéias, tecidas na predominante "linearidade” do discurso "prosaico", acabam por identificar-se com diversas “questões poéticas” de $A$ rosa do povo, às vezes de maneira tão evidente que o autor parece sugerir a complementaridade especular entre os diversos níveis da sua atuação literária (marcados, também, pela pluralidade). Não é difícil reconhecer a proximidade entre, por exemplo, o recurso aos "elefantes” pelo poeta José Boadella (do texto "Boadella entre os elefantes, p. 122-125) e o recurso ao “elefante” do poema de Drummond.

A poesia de José Boadella poderia suscitar um debate infindável. Que é poesia? Como explicá-las? Onde é segredo individual e onde é mensagem coletiva? Que parte deve ter nela a inteligência? E a parte do instinto? A palavra, em poesia, pode ter um segundo e um terceiro sentido? Que correlações de palavras é lícito ao poeta estabelecer, à margem das habituais e da convenção geral da linguagem? Se esta é um instrumento lógico, disciplinado por leis especiais, pode servir à elaboração de representações ilógicas? Há no poeta algo de específico, que o leitor comum deva assimilar, embora não preparado para isto, ou o fenômeno poético se transmite espontâneamente do criador ao leitor, viajando entre núcleos secretos idênticos? A poesia deve ser apenas uma representação estilizada do universo, ou lhe compete uma tarefa de correção dêsse universo, num plano arbitrário e sempre renovado ao sabor do capricho poético?

Os livros de José Boadella, entretanto, não respondem a nenhuma dessas perguntas. Sua poesia é provocadora, mas serena. O poeta é simplesmente um poeta, parece dizer-nos. Nem adianta que o decifremos. Decifrado ou não, o poeta nos devora, sua obrigação é devorar-nos. Devorar é empregado aqui no sentido de invasão e impregnação do espírito, por meio das sugestões da linguagem poética, isto é, coisa totalmente despojada de sentido lógico, prático,

\footnotetext{
303 "Prosaico", na definição da própria coletânea, seria "fazer versos sobre" a interioridade ou a exterioridade, "versos" que, segundo "Procura da poesia", não são "poéticos" porque não se encontram mediados pela "convivência" com as "palavras em estado de dicionário".
} 
social, moral ou metafísico. Isto faz José Boadella, com os seus versos que não têm explicação imediata e dela não necessitam. ${ }^{304}$

Na fina análise da sua crítica literária, Drummond parece projetar, como identidade, aspectos da sua própria poética na interpretação de poéticas alheias ${ }^{305}$ - o que, de resto, a metapoesia de A rosa do povo enuncia e pratica.

Ainda não é o poeta: são outros elefantes: róseo, violeta, vermelho, e o elefante cego, o elefante escossês, o elefante grego, o elefante econômico, o plástico, a dançarina grande elefanta, todos os elefantes possíveis, até o elefante poeta. O livro inteiro é um excitante e ritmado monologar de elefantes, cada qual com a sua sutileza própria (o flúido, em Boadella, também escultor em madeira, é figurado pelo que há de mais maciço como plástica). Trata-se de uma primeira pessoa multiplicada até o tédio, mas variando com a tonalidade do pêlo e a riqueza íntima de cada elefante - ou de cada pseudônimo de Boadella. $^{306}$

O título significativo da seção do livro em que esse comentário sobre Boadella se encontra é “Na rua com os homens”, que comporta, além de outros comentários sobre escritores e / ou intelectuais (os mineiros de sua geração modernista, o paulistano Mário de Andrade, o sergipano Simões dos Reis, o espanhol Lorca, o francês Mauriac e o estadunidense William Berrien) e o pintor Cândido Portinari, a sua "Autobiografia para uma revista”. Na seção anterior, “Três poetas românticos” (a primeira do livro), há três análises: a primeira, sobre Fagundes Varela (cuja "solidão poética”, ao ansiar pela comunhão com o divino e o natural e recusar o convívio humano, torna-se “imperfeita”307); a terceira, sobre Gonçalves Dias ("poeta de instituto”, “nacionalista”,

304 Carlos DRUMMOND DE ANDRADE, Confissões de Minas, p. 122-123.

305 Cf., também em Confissões de Minas, "Morte de Federico Garcia Lorca": "Porque em Garcia Lorca a Espanha de hoje tinha sua expressão lírica mais veemente e ao mesmo tempo mais concentrada, mais sutíl. Não era homem de partido. Era um poeta, ou seja um indivíduo dotado do poder de re-criar os objetos e a atmosfera em que êles se realizam. E era também poeta no sentido medieval e eterno em que a poesia é dom que se distribui, meio de comunicação entre os homens, efusão lírica da massa concentrando-se num indivíduo e refluindo sobre a massa através dos cânticos que o indivíduo produziu sob a sua influência e o seu ditado. Sua experiência poética, rica de ensinamentos fecundos, mostra a possibilidade de co-existência de um grande poeta nacional com uma força poética universal. Assim, poude renovar a tradição gitana dos romances e canções, em versos que têm o colorido forte de Granada, os cheiros e palpitações sensuais daquela terra amorosa, e, ao mesmo tempo, integrar-se na corrente supra-nacional daqueles que, em diferentes países do mundo, conseguiram depurar a poesia de tudo quanto é acidental, insubstancial ou meramente decorativo. A solução harmoniosa dêsse pseudo mas comprometedor conflito entre o local e o universal é, para mim, a primeira lição de Garcia Lorca. (Entre nós, haverá quem a aproveite). A segunda reside no seu conceito rigorosamente popular de localismo.” (p.109-110)

306 Idem, ibidem, p. 123-124.

307 Neste "Fagundes Varela, solitário imperfeito", Drummond aponta, após citar diversos trechos de poemas de Varela: 
que, ao louvar D. Pedro II e flertar com o “indianismo”, reduz o "épico” ao “pitoresco”); e a segunda, sobre Casimiro de Abreu, em que há a afirmação:

O segrêdo de dizer coisas tristes sem envenenar muito a vida faz de Casimiro um parente de todos nós. Sua leitura não é uma provocação ao suicídio, nem torna sedutora a imagem da morte. Pelo contrário. O poeta receia morrer moço e pede que, se isto tenha de acontecer, "não seja já" (assonância a meu ver admirável, pelo que lembra da gagueira de pavor diante da morte). ${ }^{308}$

A referida "gagueira”, embora não mais “assonante”, torna-se o mote do poema drummondiano "Os últimos dias”, o que se revela mais um dos diversos intertextos em A rosa do povo (sendo, além disso, mais uma apropriação da tradição romântica brasileira pela coletânea). Vejam-se os versos:

1. Que a terra há de comer.

2. Mas não coma já.

36. No mesmo ventre o escuro inicial, na mesma terra

37. o silêncio global, mas não seja logo.

Drummond afirma que Casimiro de Abreu:

... concilia o pessimismo de determinada condição pessoal - o moço pobre, escravizado econômicamente ao pai, à espera de que a glória ou o amor o vá tirar da triste vida de empregado no comércio - com o gosto da vida natural, entre as árvores frutíferas, pássaros que nos distraem com o seu canto e que apanhamos em armadilhas, e o mais que compõe o quadro singelo das pequenas cidades do interior, confundidas com o campo. É uma poesia de horta e campina, em que há laranjeiras com sabiás, regatos brincalhões, raios de lua e brisas travessas; nenhuma suspeita do Amazonas.Tudo isso envolto numa névoa das recordações ou mais patèticamente no que êle chama, num achado, "este pó da infância”.

As "Poesias Elegíacas" inserem nesse todo de melancolia conformada uma nota áspera e desconcertante. Aí, Casimiro por vêzes deixa de ser o jovem de sentimentalismo epidérmico, esvaindo-se em queixumes e suspiros crepusculares, para exprimir - ou denunciar - alguma coisa de mais forte, mais inquietante, que nêle irrompe surdamente. ${ }^{309}$

\footnotetext{
“Não é preciso mais. 'Deserto', 'ermo', 'proscrito', 'exílio'são palavras que a todo instante fluem dessa boca amarga. Estamos diante de um solitário.

Mas olhe-se mais de perto esse solitário e ver-se-á que ele pertence à espécie dos que não amam a solidão. Dos que têm medo dela. Alguns dos seus versos, aqui e ali, denunciam certo desapontamento, certa irritação produzida pelos contatos infelizes com o mundo. Dir-se-ia que o mundo o repeliu, ou, quando menos, o ignorou ..." (idem, ibidem, p. 21).

${ }^{308}$ Idem, ibidem, p. 32.

${ }^{309}$ Idem, ibidem, p. 32-33.
} 
Essa compreensão sagaz da obra de Casimiro de Abreu por Drummond faz com que se suavize o tom satírico do poema modernista "Nos áureos tempos" a poemas românticos como "Meus oito anos”310: a tradição literária do romantismo brasileiro vêse, antes, reverenciada que recusada, no intertexto (ainda que aspectos importantes sejam alvo de apreciação crítica, como se pode notar). Numa outra seção de Confissões de Minas (a quinta e última: “Caderno de notas”), há um texto que também ilumina "Nos áureos tempos":

Às vezes tenho vontade de discar o número dez mil.

O número dez mil, como a hora $H$, existe, mas ninguém o conhece. Não consta da lista telefônica; os tratados de matemática não o registram; os mais perfeitos contabilistas o ignoram. Entretanto, o número dez mil é aquêle que, uma vez discado, oferece a você a voz mais harmoniosa que já se ouviu desde a aurora do mundo; voz que você pressentia devesse andar por aí perdida numa garganta, como certas vêzes pressentimos que um anjo passou no ar: em sigilo, sem que os melhores de nós chegassem a vislumbrar-lhe a ponta dos vestidos. ${ }^{311}$

Essa imagem parece associar-se diretamente aos primeiros versos do poema:

1. Nos áureos tempos

2. a rua era tanta.

3. O lado direito

4. retinha os jardins.

5. Neles penetrávamos

6. indo aparecer

7. já no esquerdo lado

8. que em ferros jazia.

9. Nisto se passava

10. um tempo dez mil.

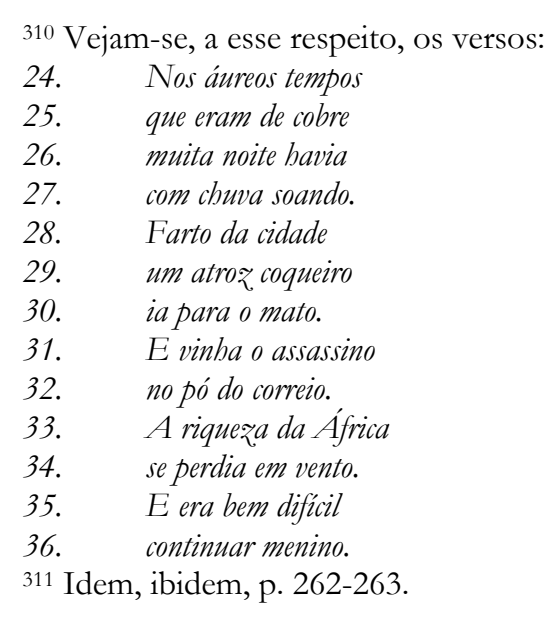


Como em outros poemas ("Vida menor”, "Nova canção do exílio”), a figuração do "exílio", no tempo ou no espaço psíquicos, tem uma natureza ambivalente, que, ao final, termina por denunciar a objetividade insuportável do aqui-agora (mais do que propor um “voumemborismo",312 de fato).

E ela [a "voz mais harmoniosa que já se ouviu desde a aurora do mundo"] virá atrás desses sentimentos ["a castidade, a bondade, a caridade, o perdão das ofensas, o gosto de ficar rezando ou lembrando-se das rezas decoradas na infância, a humildade, a resignação, e o amor”], esplêndida como uma rainha, mas sem orgulho nenhum. Pousará a mão em seus cabelos. Dirá: "Porque custaste tanto a chamar-me, Teodureto! Eu estava no teu primeiro sonho, à espreita de um sinal do teu dedo ainda incerto. Dòcilmente acompanhei o teu itinerário. Conheci as tuas namoradas. DebruceiOme à beira de tuas orgias. Escondi-me entre os teus livros. Uma noite descobri em ti, num segundo, a vontade de matar. Muitas vêzes, ao contrário, pensaste em morrer; naquele quarto de hotel, em Pasárgada, fui eu que tirei as balas do teu revólver. ${ }^{313}$

Entre o espírito de "crônica” e "conto", figuram-se questões que, no mesmo livro “de prosa”, ou então em "poemas" de A rosa do povo, encontram-se sob outra “tonalidade”, ou outro "gênero".

Essa neblina que desde ontem envolve a cidade, e torna as mulheres mais estranhas, os homens menos cotidianos - essa neblina não te dá vontade de partir?

Partir para uma ponta de ilha brumosa, de onde vieram os teus antepassados; partir para a Bretanha ou para a Escócia, para a Finlândia ou para a Dinamarca? ${ }^{314}$

A “evasão”, que se poderia identificar mais propriamente com o “ennui” de 1951 (anunciado em Claro enigma), ou então com o segundo livro de prosa (Passeios na ilha,

\footnotetext{
312 A expressão remete ao ensaio “A poesia em 1930” de Mário de Andrade (in Aspectos da literatura brasileira, p. 41-42), em que o autor nota: "Muito curioso de observar é o Vou-me embora pra Pasárgada, com que Manuel Bandeira deu afinal a obra-prima poética dum estado espírito bastante comum nos poetas brasileiros de hoje. Já o início desse título-refrão que percorre a poesia, é duma unanimidade brasileira muito grande. Nos poetas românticos o tema do exílio e do desejo de voltar é freqüente. Com o neo-romantismo dos nossos parnasianos, o tema das barcas, das velas que partem e 'não voltam mais' foi substituindo a ave que voltava ou queria voltar ao ninho antigo. No neo-neo-romantismo dos contemporâneos, o desprendimento voluptuosamente machucador, a libertação da vida presente, que se resume na noção de partir, agarrou freqüentando com insistência significativa a poesia nova. (...) Se servindo pois dessa constância nacional, Manuel Bandeira fez ela coincidir com um estado de espírito bem dos nossos poetas contemporâneos, incontestavelmente menos filosofantes que os das duas gerações espirituais anteriores (...) porém mais em contato com a vida quotidiana e mais desejosos de resolvê-la numa prática de felicidade. Incapazes de achar a solução, surgiu neles essa vontade amarga de dar de ombros, de não se amolar, de partir pra uma farra de libertações morais e físicas de toda espécie. Vontade transitória, episódica, não tem dúvida, mas importante, porque esse não me-amolismo meio gozado deu alguns momentos significativos da poesia ou da evolução espiritual de certos poetas contemporâneos brasileiros."

313 Carlos DRUMMOND DE ANDRADE, ibidem, p. 263-264.

314 Trata-se do texto "Neblina", disposto na seção "Caderno de notas" (idem, ibidem, p. 232-233).
} 
de 1952), está por diversas vezes figurada, na forma de "crônica" ou de "ficção", em Confissões de Minas - como também em A rosa do povo. Que essa discussão possa recorrer, em alguns poemas, a uma aparência hermética, isso não restringe o plano do significado ao “absenteísmo auto-referente”, “intrínseco à linguagem poética / ficcional”, quando, na verdade, é uma forma bastante eficaz de “misturar” práticas “poéticas” e referências a questões tão "literárias” quanto "políticas”, desde que se considerem (como, de fato, se faz necessário), a relação entre texto e contextos. A “ficção” que acabamos de citar termina com a seguinte observação:

Mas como é impossível partir - os caminhos são compridos e os meios são curtos e a vida está completamente bloqueada - tu te resignas a tomar o teu grogue no bar do hotel, nessa hora mais que todas tristíssima - seis horas da tarde, enquanto a neblina cai lá fora, e as mulheres passam monstruosas e vagas como desenhos indecisos, que a mão constrói para apagar logo depois. ${ }^{315}$

O que fica evidente neste texto é o recurso ao gauchismo, que desdobra a consciência subjetiva num diálogo entre eu e tu (sob o qual cabe, também, o leitor), mas que, fundamentalmente, é um aspecto do próprio “eu lírico”. Evidencia-se, também, na imagem da "hora mais que todas tristíssima”, a mesma problemática “cotidiana” do poema "Uma hora e mais outra":

61. Pois hora mais triste

62. ainda se afigura;

63. ei-la, a hora pequena

64. que desprevenido

65. te colhe sozinho

66. na rua ou no catre

67. em qualquer república;

68. já não te revoltas

69. e nem te lamentas,

70. tampouco procuras

71. solução benigna

72. de cristo ou arsênico,

73. sem nenhum apoio

74. no chão ou no espaço,

75. roídos os livros,

76. cortadas as pontes,

77. furados os olhos,

78. a língua enrolada,

79. os dedos sem tato,

315 Idem, ibidem, p. 232-233. 
80.

a mente sem ordem,

81. sem qualquer motivo

82. de qualquer ação,

83. tu vives: apenas,

84. sem saber por que,

85. como, para que,

86. tu vives: cadáver,

87. malogro, tu vives,

88. rotina, tu vives

89. tu vives, mas triste

90. duma tal tristeza

91. tão sem água ou carne,

92. tão ausente, vago,

93. que pegar quisera

94. na mão e dizer-te:

95. Amigo, não sabes

96. que existe amanhã?

Nesse poema, como nos demais de A rosa do povo (notadamente os da "aporia" e os poemas do "bloco da escavação da memória patriarcal"), encarar "a fundo" o impasse "noturno" (ainda que isso assuma a forma da "fuga") é, a um tempo, denunciar o "presente interdito" e transfigurá-lo (por "cifras" ou "jornalisticamente") numa "passagem da noite" que, invariavelmente (como "projeção" ou na forma de "fatos", tais como "batalhas"), aponta para a "reescritura" de "cidades" sob a forma de "um terceiro tom / a que denominamos aurora". Dessa maneira, a dimensão formalmente integrativa (metalingüística) da "participação", em A rosa do povo, pode dirigir-se a um "não-lugar" ("insulamento") ou ao "tempo da infância", sem perder o "sentimento do mundo" na "maturidade" e na "experiência individual" no "tempo presente".

Será a criança um ser à parte, estranho ao homem, e reclamando uma literatura também à parte? $?^{316}$

A preocupação de Drummond com a "infância”, em Confissões de Minas e em A rosa do povo (cuja origem remete, antes, a Alguma poesia ${ }^{317}$ ) aprofunda uma problemática, à época, inédita no Brasil ${ }^{318}$, e delicada em todo o mundo, tornada digna de reflexão a partir do pensamento freudiano.

\footnotetext{
316 "Literatura infantil”, na seção "Caderno de notas" (idem, ibidem, p. 220).

317 Veja-se o poema "Infância".

318 As práticas psicanalíticas de Nise da Silveira, ainda hoje, são um tabu na medicina psiquiátrica brasileira. (Há que lembrar que a médica, contemporânea de Graciliano Ramos, também foi presa no governo Vargas, sendo mencionada no autobiográfico Memórias do cárcere, do romancista.) Como toda idéia ou sistema conceitual na literatura drummondiana, entretanto, também a psicanálise sofre, quando não o escárnio, ao
} 
O auto-proclamado "individualismo" drummondiano, ainda que se afirme com "ressalvas”, não se opõe, num suposto "pólo antinômico”, ao “engajamento”, sendo antes a sua pré-condição.

Casado, fui lecionar geografia no interior. Voltei a Belo Horizonte, como redator de jornais oficiais e oficiosos. Mário Casassanta levou-me para a burocracia, de que tenho tirado o meus sustento. De repente, a vida começou a impor-se, a desafiar-me com seus pontos de interrogação, que se desmanchavam para dar lugar a outros. Eu liquidava esses outros, mas apareciam novos. Meu primeiro livro, Alguma Poesia (1930), traduz uma grande inexperiência do sofrimento e uma deleitação ingênua com o próprio indivíduo. Já em Brejo das Almas (1934), alguma coisa se compôs, se organizou; o individualismo será mais exacerbado, mas há também uma consciência crescente da sua precariedade e uma desaprovação tácita da conduta (ou falta de conduta) espiritual do autor. Penso ter resolvido as contradições elementares da minha poesia num terceiro volume, Sentimento do Mundo (19140). Só as elementares: meu progresso é lentíssimo, componho muito pouco, não me julgo substancialmente e permanentemente poeta. Entendo que poesia é negócio de grande responsabilidade, e não considero honesto rotular-se de poeta quem apenas verseje por dor-de-cotovelo, falta de dinheiro ou momentânea tomada de contato com as forças líricas do mundo, sem se entregar aos trabalhos cotidianos e secretos da técnica, da leitura, da contemplação e mesmo da ação. ${ }^{319}$

Neste e em outros textos de Confissões de Minas, bem como por todo A rosa do povo, o conceito de “poesia” é exaustivamente discutido, seja pelo discurso analítico (da “autobiografia”, da “crítica literária” e de outras formas “prosaicas”), seja pela figuração “poética”. Não é difícil identificar um tom “analítico” também em poemas de A rosa do povo (como “Consideração do poema”, ou "Procura da poesia”), assim como não é difícil encontrar um discurso propriamente denso na "prosa" drummondiana. Sobretudo, a consciência da "poesia" como resultado complexo dos "trabalhos cotidianos e secretos da técnica, da leitura, da contemplação e mesmo da ação”, embora enuncie o intento de resolver as suas “contradições elementares”, não parece pretender um “meio termo” entre o “individualismo precário” e a “tacitamente desaprovada conduta espiritual (ou falta de)”. Em outro texto de Confissões de Minas (também

menos uma figuração eivada de criticidade. Em Confissões de Minas, na seção "Quase histórias", Drummond a satiriza, no pequeno conto autobiográfico "Um escritor nasce e morre": "A poetisa Laura Brioche fundou um Clube de psicanálise, que procurei desmoralizar na primeira reunião, introduzindo sub-repticiamente entre os sócios, antes da votação dos estatutos, volumosa quantidade de "whisky", genebra e gim. A sessão dissolveuse em álcool, mas restaram aqui e ali grupos de bem-aventurados que se entretinham na interpretação onírica e confrontavam gravemente os seus respectivos complexos, recalques e ambivalências." (idem, ibidem, p. 206).

319 “Autobiografia para uma revista”, seção "Na rua com os homens" (idem, ibidem, p 72-73). 
autobiográfico, mas poeticamente mais denso), os dois “pólos” são satiricamente desfigurados:

Licurgo, que compusera comigo o "Poema do Cubo de Éter", descobriu certa noite o tomismo, e eu o expulsei da minha convivência. Mas sua voz continuou pregando os novos tempos e perturbando almas sedentas de verdade e metafísica.

Aleixanor, tendo comprado num sebo as "Cartas aos operários americanos", de Lenine, e começando a colaborar no "Grito Proletário", sofreu da minha parte uma campanha de descrédito intelectual. Voltou-se para a ação política, fundou sindicatos, escreveu e distribuiu manifestos, e desfrutou de certa notoriedade até o golpe de 35, quando emudeceu.

(...)

Todos, em redor de mim, se iam afirmando, iam-se fixando.

Todos optavam. Nos jornais, passavam do suplemento dos domingos para a página editorial. Alguns recebiam manifestações de aprêço, outros eram chamados para trabalhar nos gabinetes de secretários de Estado. Vários compraram lotes e começaram a edificar. Um dêles, extraordinário, conquistou um cartório. Uma floração de filhos, vitoriosos nos concursos de puericultura, afirmava o rumo seguro da minha geração.

Eu perseguia o mito literário, implacàvelmente, mas sem fé. Nunca meus poemas foram mais belos, meus contos e crônicas mais fascinantes do que nesse tempo de crescente solidão. Solidão, solidão... Era só o que havia em tôrno de mim, dentro de mim. Era como se morasse numa cidade que, pouco a pouco, fôsse ficando deserta. Algum tempo mais, e não haveria ninguém para dirigir os sinais luminosos nas esquinas, para dar corda aos relógios, velocidade aos bondes, carne, pão e fruta às casas. (...)

Risquei um fósforo, já sob a escuridão absoluta, e na lâmpada que as minhas mãos em concha formavam, percebi que tinha feito 30 anos. Então morrí. Dou a minha palavra de honra que morrí, estou morto, bem morto. ${ }^{320}$

Seja o "tomismo", ou o “marxismo-leninismo", ou ainda o "arte-purismo", nenhum desses "tipos” figurados (como de resto a própria "figura” do escritor) são poupados pelo escárnio, ainda que também não sejam recusados em absoluto. A figuração apenas os “individualiza” para refletir sobre eles de maneira distanciada, mas que não implica “objetividade” absoluta (quando, de fato, é relativização). Tomar essa “prosa” em seu sentido literal, apenas, é desconsiderar outros níveis (os quais encontram-se presentes, tanto na “prosa” como na “poesia” drummondianas), em que, mesmo os textos mais "objetivos" (como por exemplo a "Autobiografia para uma revista”), não podem ser tomados em seu sentido imediato, aparente ${ }^{321}$.

\footnotetext{
320 "Um escritor nasce e morre", seção "Quase histórias" (idem, ibidem, p.205-207).

321 Nesse mesmo texto, Drummond afirma: "O meu sorriso gauche, de dentes não suficientemente íntegros (ganhei fama de irônico por causa do sorriso envergonhado), sublinhava a discreta intenção da negativa [quanto aos elogios da crítica, após a publicação de seus três primeiros livros de poesia]." (p. 203) É evidente que a ironia drummondiana, em que pese o traço tímido de seu psiquismo, bem como a sua característica
} 
O equívoco entre poesia e povo é já demasiadamente sabido para que valha a pena insistir nêle. Denunciemos antes o equívoco entre poesia e poetas. A poesia não se "dá", é hermética ou inumana, queixam-se por aí. Ora, eu creio que os poetas poderiam demonstrar o contrário ao público. De que maneira? Abandonando a idéia de que poesia é evasão. E aceitando alegremente a idéia de que poesia é participação. Não basta dizer que já não há tôrres de marfim; a tôrre desmoronou-se pelo ridículo, porém muitos poetas continuam vendo na poesia um instrumento de fuga da realidade ou de correção do que essa realidade ofereça de monstruoso e de errado. Desenvolve-se então entre êles a linguagem cifrada que nenhum leigo entende, e que suscita o equívoco já célebre entre poesia e povo.

Participação na vida, identificação com os ideais do tempo ( e êsses ideais existem sempre, mesmo sob as mais sórdidas aparências de decomposição), curiosidade e interêsse pelos outros homens, apetite sempre renovado em face das coisas, desconfiança da própria e excessiva riqueza interior, eis aí algumas indicações que permitirão talvez ao poeta deixar de ser um bicho exquisito para voltar a ser, simplesmente, um homem. ${ }^{322}$

O que uma "face" da obra parece afirmar em absoluto, a "outra” torna relativo, ou pela mudança de tom, ou pela afirmação do mesmo, mas em negativo (por ironia ou projeção). Que “poesia” e “povo” não se equivalem, isso não significa que não possam, como nos versos finais de “Consideração do poema”, “atravessar-se” (desde que isso resulte de uma consciência lingüística marcada). É essa consciência que impede, na obra drummondiana, a “poesia”, a “prosa”, a “autobiografia”, o “conto”, a “crônica”, o “autor”, o "leitor” e todos os elementos e conceitos pré-definidos, de figurarem no plano do imediato. Por isso, faz-se necessário encontrar, entre a imediata referencialidade da "prosa” e o discurso mediado pela densidade significante da "poesia”, os fatores que inter-relacionam os níveis da significação e do significado.

Declaro honestamente que falta a meu livro isso que para mim, neste domingo de agôsto, é o mais precioso de tudo: falta-lhe o tempo, com suas definições. A páginas foram se escrevendo mais para contar ou consolar o indivíduo das Minas Gerais, e dizem bem pouco das relações dêsse indivíduo com o formidável período histórico em que lhe é dado viver. Mesmo assim, douas como um depoimento em negativo, indicando aos mais novos que devem formular depoimentos positivos, autênticos e até mesmo impiedosos, se fôr o caso. $^{323}$

gauche, se elevam à importância simbólica, que transcende a biografia, ampliando os seus significados (o que, afinal, também vale para esta auto-referência do Autor).

322 "Poesia do tempo", na seção "Caderno de notas" (idem, ibidem, p 218-219).

323 Trata-se da "Introdução" (idem, ibidem, p. 8-9). 
Por sob a enunciação da precariedade da própria obra, nota-se a estratégia gauche, ex-cêntrica, de visar à mediação. Não há, em Drummond, enunciação direta de idéias ou conceitos (e, nem por isso, pode-se tomar a afirmativa drummondiana como literal “consciência do fracasso”).

Não estou pois dentro dêste livro de retalhos, e sim fora dêle. Mas sinto que foi um caminho pelo qual cheguei a uma excelente cidade, de ruas largas $e$ populosas. Elle abriu minhas gavetas secretas. Libertou-me de alguns fantasmas particulares. Agiu. Hoje não escreveria quase nada do que aí se contém, mas por isso mesmo a sensação de desprendimento e liberdade é maior. Vamos andando. ${ }^{324}$

A escrita drummondiana não é, nunca, a coincidência entre forma e enunciado, entre eu e mundo, entre autor e personae, ou entre a condição objetiva e o projeto subjetivo. Por isso, ela recorre, num grau obsessivo, à metalinguagem, e também por isso o seu engajamento pode implicar a "participação" (mas nunca a coincidência absoluta) da linguagem em questões, por exemplo, políticas. Nesses termos, a "pólis” não será “cantada”, mas “reescrita”, o que é uma maneira de não fazer “versos sobre”, e, ainda assim, incorporá-la (ainda que “em negativo”). Esta é, de fato, uma poética que se recusa a quaisquer sentidos determinados e determinantes, o que implica o dinamismo incessante e a liberdade como refeitura permanente dos vínculos (como projeto literário).

8

No ensaio “Drummond prosador”, Antonio Candido afirma:

Na sua obra a prosa de ficção parece ter um papel indispensável, na medida em que constitui o ponto intermédio na gama que vai da poesia à crônica. Isto não quer dizer que haja isolamento entre os diversos tipos da sua produção, pois, ao contrário, muito da sua obra é constituída por um trânsito de mão dupla entre eles. Eles se interpenetram com efeito freqüentemente, nem é novidade assinalar que na poesia de Drummond há um gosto acentuado pelo elemento narrativo, desde a tonalidade de "romance" popular ("O caso do vestido") até o poema-notícia ("A morte do leiteiro"), com matizes que passam

${ }^{324}$ Idem, ibidem, p. 10. 
pela efabulação marcada ("O padre e a moça" [sic]) e o relato como projeção pessoal ("A morte no avião"). Isso, para não falar nos limites fluidos da crônica propriamente dita, onde poesia e ficção se misturam a fim de produzir figuras variadas em torno da anedota, o caso singular, a cena de rua. Digamos que numa ponta ficam as estruturas especificamente poéticas, com função própria; na outra, certas prosas de cunho reflexivo ou polêmico, nutridas de idéia, protesto, denúncia, como as que têm atraído de maneira crescente esse escritor capaz de atuar com firmeza, mas sem brutalidade nem grosseria - coisa muito rara hoje. E, na base, o dom de uma prosa lírica e firme, correta sem afetação, que foi ganhando transparência mágica e ultimamente sabe incorporar com naturalidade o que há de mais expressivo nos torneios coloquiais e no vocabulário da nossa língua em mudança rápida. A partir da matriz possivelmente mineira, Drummond extraiu de um corte clássico do idioma os movimentos mais livres. ${ }^{325}$

Em relação a A rosa do povo, de fato, não há como estudar os poemas isolandoos em relação à coletânea, ou ao conjunto da obra poética, ou, ainda, em relação à obra “prosaica”, especialmente Confissões de Minas.

Confissões de Minas foi o seu primeiro livro de prosa, e nele está a gama da sua virtuosidade fora do verso. Há crítica literária, estudos de personalidade, comentário lírico e anedótico sobre o quotidiano, mostrando que ele não é um cronista no sentido estrito, como são Rubem Braga, ou Rachel de Queiroz e Fernando Sabino quando fazem crônica. O que ele próprio chama assim são escritos de latitude maior ${ }^{326}$

É possível apontar diversos outros contatos entre o primeiro livro de “prosa” e o quinto livro de “poemas” de Drummond, além dos que apontamos anteriormente, e é necessário observar que o próprio sentido de "prosa” e de “poesia” (como, de resto, quaisquer outras convenções literárias) desfazem-se / refazem-se na obra drummondiana (e, em especial, em A rosa do povo), segundo o projeto literário.

Se for assim, talvez seja prudente apagar os esquemas e divisões sugeridos nesta introdução. (...) talvez só haja um Drummond, nem poeta, nem ficcionista, nem cronista, instalado na posição-chave da sua competência soberana, a partir da qual variam os modos de penetrar no meandro da "humana contingência".

Por isso, é claro que na sua poesia há ficção e crônica; na sua crônica, poesia e ficção; na sua ficção, crônica e poesia - tudo formando o que para ele decerto são tentativas, mas para nós são realizações completas e exemplares. ${ }^{327}$

\footnotetext{
325 Antonio CANDIDO, Recortes, p. 14.

326 Antonio CANDIDO, op. cit., p. 14.

327 Idem, ibidem, p. 18-19. Neste outro ensaio fundamental sobre a obra de Drummond, há mais um elemento chave para a compreensão da poética integrativa de $A$ rosa do povo, coletânea em que o conflito entre
} 
A nosso ver (e por sugestão do outro ensaio de Antonio Candido, "Inquietudes na poesia de Drummond”), o que leva os poemas de A rosa do povo a alcançar uma riqueza temático-formal inclassificável é a prática obsessiva da metalinguagem, a efetuar a síntese entre diversos embates, que apenas aparentemente (no plano da denotação, e ainda assim de maneira relativa e provisória) se apresentam como antíteses $^{328}$ (sendo todos derivados do “núcleo temático” eu versus mundo). Assim, aspectos da “epopéia” e da própria “lírica” (entre outros "gêneros poéticos”), bem como aspectos da "crônica”, da "notícia”, da "autobiografia” (entre outros "gêneros prosaicos”), não são senão figuras através das quais o discurso, especularmente, desfigura aspectos do real, referenciados mimeticamente (mas não de modo imediato), para transfigurá-los, segundo aspectos volitivos da subjetividade gauche (vinculados ao ideário socialista e a preocupações “políticas”, conceito compreendido não apenas no seu sentido institucional restrito).

Uma outra dimensão que é necessário apontar no diálogo especular (praticamente explícito) entre Confissões de Minas e A rosa do povo é a "vocação monográfica”.

Drummond chama de crônica ao resto dos seus escritos em prosa, mas creio que é preciso fazer algumas distinções para poder aceitar esta designação, a meu ver extremamente modesta. A julgar pelas coletâneas em livro, ela só pode ser considerada plenamente válida depois de Fala, amendoeira, pois o cronista foi se decantando a partir de uma atividade mais complexa, refletida nos livros iniciais, Confissões de Minas e Passeios na ilha, constituídos, como vimos, por uma série de escritos de natureza variada.

Entre estes, há alguns que têm características de "estudo" e manifestam um aspecto muito próprio de Drummond: a solidez da informação, que ele atenua por meio do tom ocasional, como se aquilo estivesse brotando à medida que a pena corre. É o caso da "Carta aos nascidos em maio"(Passeios na ilha), onde o conhecimento quase erudito se dissolve na gratuidade coloquial. Mas noutros lugares não ocorre este disfarce modesto; veja-se, no mesmo livro, "Rosário dos homens pretos", que deixa patentes a investigação documentária e

\footnotetext{
o "poético" e o "prosaico" não faz sentido, na medida em que a ressignificação do próprio conceito de "literatura" (isto é, dos seus "recursos fundamentais", dos seus "gêneros" e demais convenções) é parte integrante do projeto estético, marcado por preocupações políticas. Inspirados nessa tese de Antonio Candido, intitulamos esta Segunda Parte do nosso estudo de "A prosa do poeta" (trata-se de um dos subtítulos do referido ensaio "Drummond prosador", ligeiramente modificado).

328 Convém reiterar a diferenciação entre "antítese" e "antinomia", ou "dicotomia", segundo um ponto de vista dialético. Num pensamento integrativo, o conflito de tipo antitético difere radicalmente de um conflito de tipo antinômico, na medida em que, no primeiro caso, mas não no segundo, ele é superado, transformando-se em síntese, e essa síntese refunda conflitos de novo tipo, e não um equilíbrio de tipo harmônico ou pendular.
} 
a força da interpretação histórica. De fato, a dinâmica da sociedade mineira do século XVIII é analisada do ângulo da luta de classes, através das confrarias religiosas, e no fim surge o material documentário, para estaquear a argumentação e tirar qualquer dúvida ao leitor. Cronista? Só se for nalgum velho sentido de expositor penetrante dos fatos.

Poder-se-ia então dizer que em Drummond há entre outras uma vocação monográfica, disfarçada às vezes pelo relato impressionista. ${ }^{329}$

Em "Vila de Utopia”, de Confissões de Minas, por exemplo, Drummond figura, sob o tom "ficcional” (alegórico), aspectos de Itabira que, certamente, resultaram de funda investigação. ${ }^{330}$

A casa era grande, na rua Municipal: dois andares que subiam cheios de portas e sacadas, oferecendo a frontaria sem ornatos, maciça, impressionante, à admiração dos que passavam. Dentro dela, olhando para o pátio central, outro sobrado, êste menor, guardava cômodos inúteis; parecia um pombal. Em 1911 êsse sobradinho desapareceu, mas a casa não diminuiu de tamanho, os passos ecoavam ainda nos mesmos imensos corredores, nas mesmas salas infinitas. E nela existiam desvãos que nós nunca havíamos explorado. Por baixo da escada, por cima da copa, aqui, ali, o mistério abria-nos os seus lares. Mas nós crescíamos depressa e não púnhamos reparo na casa grande.

Sabíamos que a casa tinha muitos anos, que ali morreram avós, tios e primos; em tal quarto nasceu meu pai, naquele outro meu avô estendeu, até à morte, uma perna baleada nas últimas eleições sangrentas do município; mas nós circulávamos livremente através do ar coalhado de lembranças e eflúvios familiares, de pesadas e obscuras memórias dos coronéis e das damas antigas, dos vestidos de dona Joana e das festas do comendador Paula Andrade.

Com a mesma inconsciência natural nós crescemos e nos dispersamos; um dia a casa foi vendida, e então um amargor sem aviso prévio, uma angústia nos subiram à boca, aos olhos; verificámos como aquela casa fazia parte da nossa vida, e como essa vida ficava sem explicação, despregada das enormes paredes azuis que o Andrade dominador salvára da ruína para compor com elas o nosso quadro infantil e humano.

(...) Como foi que a infância passou e nós não vimos? Até hoje interrogo aquêle menino que durante quatro anos foi aluno deploràvelmente bom do grupo escolar, e não o sinto nem aprumar-se, nem enriquecer-se de experiências vitais, nem desprender-se do cenário familiar. No entanto, o menino existiu, sofreu, brigou, amou, desesperou, cresceu. Vinte anos depois, voltando à cidade, não encontrei vestígio algum da aventura individual. Só a velha casa continuava, espetacularmente azul na rua deserta, de onde haviam desaparecido o tabelião Barnabé e o coletor Quinca Custódio, mas onde restava o inesgotável Fernando Terceiro, ainda ereto, fazendo sempre o comentário sarcástico dos acontecimentos e dos homens entre os quais incluia o seu vizinho e também humorista Minervino Betônico.

${ }^{329}$ Idem, ibidem, p. 161-17.

${ }^{330}$ Cf. Chantal CASTELLI, "Matrizes históricas de um poema”, in Lembranças em conflito, p. 18-44. 
(...) Os velhos da cidade, no meu tempo, já não podiam dizer da velha Itabira, porque êles mesmos não a haviam alcançado. ${ }^{331}$

Ler essa "crônica” de Confissões de Minas é identificar, em forma "prosaica”, diversos trechos de poemas de A rosa do povo, fundamentalmente "Nosso tempo" (em que o eu lírico visita a "casa", numa tentativa desesperada, e frustrada, de reconhecer-se nos seus cômodos, depois do quê, passa a interrogar pessoas e objetos, incapazes entretanto de “contar"). A “crônica”, escrita em 1933, resultou, não apenas, de evocações do poeta, mas, certamente, de pesquisa, e, sobretudo, de uma fina análise de vocação "historiográfica" ${ }^{332}$. Nela, Drummond estabelece três períodos, a partir dos quais analisa aspectos sócio-econômicos de Itabira com senso agudo de suas historicidades.

Porque a primeira Itabira, a Itabira do ouro, essa não tinha outra fórma senão a que lhe traçaram, com a ponta do pé, os desbravadores sequiosos, na sua "exploração insensata e ruinosa das lavras", de que fala Eschwege. As leis vinham de Vila Nova da Rainha, para onde ia o trabalho e o suor dos mineiros, convertidos em impôsto; as bênçãos e as proibições morais vinham de Santa Bárbara, onde a igreja assentara a sua freguesia. Na encosta áspera, os pretos vibravam a picareta, mergulhavam os pés na água escassa e barrenta. Um ou outro, com exterma dificuldade, ocultava na carapinha a pedra que daria para forrá-lo. Quando o amo não fôsse como o citado capitão Tomé, de quem os negros fugiam, espavoridos, para precipitar-se na minha, onde dizem que um morreu asfixiado.

Que resta dessa velha Itabira? Um mapa do sargento Bougadas, quando o povoado já sentia aproximar-se a sua elevação a vila. Procuràmos, eu e Luiz Camilo de Oliveira Neto, êsse mapa no Arquivo Público Mineiro, onde deveria estar, mas sumiu, como o sargento Bougadas, de que só padre Júlio conserva o nome precário.

Haverá uma terceira e diversa Itabira? Meu Deus, como me doeria responder sim à pergunta, e confessar que em 1933 o antigo menino da rua municipal foi encontrar a sua cidade habitada por um pelotão de velhos, que nada poderiam dizer, e por um exército de rapazes e meninas, aos quais não tinha nenhuma mensagem para dirigir. Entre aquêles velhos e estas crianças, êle passeou ràpidamente a sua incorrigível inquietação de trinta anos, a sua falta de solidariedade com as coisas, a sua saudade, a sua disponibilidade. E o seu sofrimento foi como uma picada fina, penetrante, na carne do braço. ${ }^{333}$

Não há como não notar o paralelismo entre esse trecho em "prosa” e o seguinte trecho de "Nosso tempo":

65. Ó conta, velha preta, ó jornalista, poeta, pequeno historiador urbano,

66. ó surdo-mudo, depositário de meus desfalecimentos, abre-te e conta,

67. moça presa, na memória, velho aleijado, baratas dos arquivos, portas

[rangentes, solidão e asco,

68. pessoas e coisas enigmáticas, contai,

69. capa de poeira dos pianos desmantelados, contai;

331 Carlos DRUMMOND DE ANDRADE, op. cit., p. 135-142.

332 Chantal CASTELLI, op. cit., p. 21-27.

${ }^{333}$ Carlos DRUMMOND DE ANDRADE, op. cit., p. 143-144. 
70. velhos selos do imperador, aparelhos de porcelana partidos, contai;

71. ossos na rua, fragmentos de jornal, colchetes no chão da costureira, luto

[no braço, pombas cães errantes, animais caçados, contai.

72. Tudo tão difícil depois que vos calastes...

73. E muitos de vós nunca se abriram.

Uma outra problemática de $A$ rosa do povo aparece na mesma crônica:

Abro ao acaso as "Meditações Sul-americanas", de Keyserling, e fico pensando se o autor teria diante de si o cidadão de Itabira, quando apontou as características espirituais da parte meridional do Continente. Embora dificilmente aplicável à realidade psicológica brasileira o seu conceito de "gana”, vale a pena ouví-lo quando diz, por exemplo: “O sul-americano (o itabirano) é passivo. Ele suporta a sua vida, e não conhece outra maneira de viver. Cede pouco às influências exteriores, mas capitula incessantemente diante da impulsão interior". "Todo ato sul-americano (itabirano) resulta do abandono a essa impulsão". "A vida, aí, não segue uma direção, mas uma inclinação. Nada de espantoso, pois, em que, refletida pela consciência intelectual, evoque um abismo de melancolia e um abismo de cepticismo. Não se passa nada de novo. Nada serve para nada. Nenhum esfôrço vale ser tentado”. E finalmente: ... a prodigiosa monotonia que paira, que está suspensa, por assim dizer, na fisionomia moral da America do Sul (de Itabira)...”

Dessa monotonia, o conde de Keyserling extrai um "sofrimento sulamericano". Seria absurdo isolar, na sensibilidade mineira, um sofrimento itabirano? Julgo que não. Eu sou, Itabira, uma vítima dêsse sofrimento, que já me perseguia quando, do alto da Avenida, à tarde, eu olhava as tuas casas resignadas e confinadas entre morros, casas que nunca se evadiriam da escura paisagem de mineração, que nunca levantariam âncora, como na frase de Gide, para a descoberta do mundo. Parecia-me que um destino mineral, de uma geometria dura e inelutável, te prendia, Itabira, ao dorso fatigado da montanha, enquanto outras alegres cidades, ganhando-se em rios claros ou no próprio mar infinito, diziam que a vida não é um pena, mas um prazer. A vida não é um prazer, mas uma pena. Foi esta segunda lição, tão exata como a primeira, que eu aprendi contigo, Itabira, e em vão meus olhos perseguem a paisagem fluvial, a paisagem marítima: eu também sou filho da mineração, e tenho os olhos vacilantes quando saio da escura galeria para o dia claro. ${ }^{334}$

No poema "América”, a passagem metonímica da identidade itabirana, na "conversa amorosa” com o Continente, em direção à alteridade, também se utiliza da imagem "mineradora" da "escavação"; imagem que se torna decisiva em toda a figuração ambivalente da "aporia” (desfiguração / transfiguração).

O "núcleo temático" das “inquietudes”, que n’A rosa do povo é fatura formal, na referida crônica torna-se, sobretudo, enunciado:

Todos cantam sua terra, mas eu não quis cantar a minha. Preferi dizer palavras que não são de louvor mas que traem a silenciosa estima do indivíduo, no fundo,

${ }^{334}$ Idem, ibidem, p. 145-146. 
eternamente municipal e infenso à grande comunhão urbana. Ainda assim fui itabirano, gente que quase não fala bem da sua terra, embora proíba expressamente aos outros falarem mal dela. Maneira indireta e disfarçada de querer bem, legítima como tôdas as maneiras. E afinal, eu nunca poderia dizer ao certo se culpo ou se agradeço a Itabira pela tristeza que destilou no meu ser, tristeza minha, tristeza que não copiei, não furtei... que põe na rispidez $\mathrm{dz}$ minha linha de Andrade o desvio flexível e amável do traço materno. ${ }^{335}$

Trata-se, sem dúvida, de uma reflexão (figurada) sobre a personalidade literária, mais do que autobiográfica, do "poeta”, para quem os “Andrades” representam o patriarcalismo, enquanto os "Drummond", a doçura, personificada pela figura materna.

A "crônica" seguinte a essa chama-se "Viagem de Sabará" e torna ainda mais evidente a pesquisa em fontes documentais, citando versos do cancioneiro popular, transcrevendo ex-votos, interpretando elementos estilísticos de obras atribuídas a Aleijadinho, em cruzamento com dados biográficos, urbanísticos e arquitetônicos mas, sobretudo, estabelecendo interpretações, não apenas de natureza estética, como também reflexões, entre brincalhonas e sagazes, sobre a natureza da memória.

Fui, como todo mundo, visitar a igreja do Carmo. (...) às vezes é um menino que nos conduz e naturalmente ignora tudo, inclusive o nome de batismo do Aleijadinho; o velho, que se presume mais informado, tem memória fraca, pernas trôpegas; resta o sacristão, indivíduo de idade neutra, triste e vago, que desejaria mostrar-nos os livros da irmandade, mas as chaves da sacristia nunca estão em seu poder.

Conheci os três tipos na cidade; o mais interessante, vê-se logo, é o menino, que embora não saiba positivamente de nada, ou por isso mesmo, é bastante inteligente para tirar partido da curiosidade que o forasteiro mostre pelos templos. Um dêsses guias-mirins me transmitiu a idéia que fazia do Aleijadinho e não era pròpriamente falsa, posto que exagerada; Aleijadinho, confiou-me êle degustando metòdicamente um pé de moleque, era um homem sem braços nem pernas, tronco só, que fêz tôdas essas igrejas que o Sr. está vendo aí e depois foi para Ouro Preto fazer as de lá. Percebi que a "definição" fôra arranjada mais para distração do que para informação do ouvinte, mas, como não se distanciasse muito da realidade, gratifiquei devidamente o autor.

Aliás, o garoto exprimia a média da opinião corrente sôbre o Aleijadinho, personagem mítico, de contornos indefinidos, autor de uma porção de obras que nunca fêz e possuidor de uma série de característicos que jamais o distinguiram. O silêncio dos arquivos, de onde nada ou quase nada saiu até agora para iluminar a personalidade do artista, aumenta e justifica essa confusão. [Em nota de rodapé, há a seguinte observação: "(O autor escreve em 1928.)"]

Sabe-se apenas que em Congonhas do Campo existem recibos firmados pelo cinzelador dos profetas. Em Sabará ouvi falar de documentos semelhantes, e mesmo um certo Zidorinho - aqui fica o seu nome como indicação para futuros e mais afortunados pesquisadores - prometeu fornecê-los com rapidez, mediante certa quantia que o jornalista representante de "O Jornal” não teve dúvida em desembolsar prèviamente, na doce expectativa de ver brotar do fundo do passado revelações sensacionais sôbre o mais notável arquiteto e escultor

\footnotetext{
335 Idem, ibidem, p. 146-147.
} 
brasileiro. Zidorinho, porém, até hoje se conserva em discreto e pundonoroso silêncio, o que me induz a suspeitar, sem malícia, da improficuidade de suas buscas nos velhos armários de jacarandá. ${ }^{336}$

Por sob o tom despretensioso, há a participação de Drummond numa pesquisa séria, esforço no qual os modernistas foram precursores, e que teve repercussões de fato “monográficas” (como os estudos de Mário de Andrade sobre o escultor mineiro, e que contaram com a ajuda do amigo Drummond ${ }^{337}$ ) e, inclusive, políticas (considerando-se, por exemplo, a criação do Serviço do Patrimônio Histórico e Artístico Nacional, órgão em que Drummond veio a trabalhar ${ }^{338}$ ).

Assim, mesmo em escritos rotulados de "crônica", muitos perdem o toque dominante da gratuidade ocasional (que costumamos associar ao gênero) e vão caminhando para outra coisa: poema, estudo, autobiografia - ou um certo tipo de reflexão, em geral bem disfarçada, que deixa para trás o pretexto imediato e mostra uma dimensão imprevista. Esta última modalidade leva a pensar que ele pratica ao seu modo aquilo que Montaigne chamava ensaio, ou seja, o exercício em profundidade do pensamento, a partir de estímulos aparentemente fúteis ou desligados do que acaba sendo a matéria central. É em Montaigne que penso quando vejo Drummond, numa prosa que se apresenta como algo irrelevante, deslizar do papo para reflexões de um alcance $e$ densidade que nos fazem incluí-lo na família mental dos que "ensaiam" o pensamento, a pretexto de motivos inesperados; mesmo quando ele volta de repente a algo que parece insignificante, como se quisesse, por meio desse particular corriqueiro, quebrar o "ensaio" e refazer a "crônica". Ainda nisto lembra Montaigne, que pode partir da dor de dentes de um guerreiro antigo, em seguida filosofar sobre o estoicismo e acabar contando pormenores da sua administração doméstica ou dos seus males de entranha. Por isso, quando na crônica "Antigo" fala em humana contingência", o leitor pressente alguma afinidade no ar e acaba lembrando a "humaine condition". E aí concluímos que a designação "crônica" pode ser tão arbitrária em Drummond quanto

\footnotetext{
336 Idem, ibidem, p. 153-156

337 A Lição do amigo: cartas de Mário de Andrade a Carlos Drummond de Andrade, anotadas pelo destinatário, p. 103-106. 338 "Rodrigo Mello Franco de Andrade, que trocou a sua carreira e vocação de escritor pela criação de toda uma ética do funcionário público, era o homem, num meio vaporoso como o do serviço público, do faça a coisa certa. Esteve à frente do Patrimônio desde 1939, quando o órgão foi criado experimentalmente com o objetivo de proteger o acervo cultural e artístico nacional, então completamente desamparado.

A vontade política tinha partido do próprio Rodrigo Mello Franco, que arrancou do ministro da Educação, Gustavo Capanema, autorização para criar o serviço de patrimônio histórico. A inspiração, o espírito e a própria ideologia do órgão vieram das suas longas conversas e da sua correspondência com Mário de Andrade, que dariam origem em seguida ao que ficou sendo conhecido como o 'catatau do Mário' - um monte de folhas manuscritas nas quais o autor de Macunaíma dava um banho de fundamentação do papel do serviço, de conceito de patrimônio histórico, de definição de acervo, em sentido amplo, de discussão da chamada questão nacional, e de até hoje insuperada política cultural.

Drummond era o terceiro ou quarto na hierarquia do Patrimônio. Formalmente seu cargo era o de chefe da Seção de História na Divisão de Estudos e Tombamentos. Mas, na prática, ele foi durante quase vinte anos chefe do arquivo. (...) a verdade é que a forma com que ele organizou o arquivo não foi alterada até hoje." (CANÇADO, op. cit., p. 223)
} 
“ensaio" em Montaigne. Num caso e noutro, os movimentos livres do pensamento e da imaginação vinculam estreitamente o detalhe insignificante à reflexão cheia de conseqüências, de um modo que escapa às classificações. ${ }^{339}$

Esse “exercício em profundidade do pensamento", entre o “ensaio" e a “crônica”, também se pode notar em muitos dos poemas de A rosa do povo (embora em linguagem propriamente “poética”, isto é, carregada de múltiplas possibilidades semânticas), como aqueles poemas que “escavam” o “cotidiano” tripartido, transfigurando-o em direção à "gratuidade” das evocações de natureza autobiográfica (sem, contudo, abandonar a escala do lirismo e da experiência individual, desprovida do “heróico”, e marcada pelo vivido e pela "humana contingência”). É a partir dessa escala que aspectos “objetivos” (como a "política”, por exemplo) vêem-se desfigurados, e adquirem uma nova significação, caracterizada pela pluralidade de novos e mais livres sentidos (sempre transitivos).

Em termos de “engajamento político", a imagem da “cidade” a ser "reconstruída” pelo "trabalho social” (do que faz parte a "linguagem poética”, necessariamente ressignificada como “gênero" ${ }^{340}$ ) é figura chave, marcada pela consciência metalingüística do lirismo gauche:

101. Como fazer uma cidade? Com que elementos tecê-la? Quantos fogos terá? ? $^{341}$

132. Ser tão sozinho em meio a tantos ombros,

133. andar aos mil num corpo só, franzino,

134. e ter braços enormes sobre as casas,

135. ter um pé em Guerrero e outro no Texas,

136. falar assim a chinês, a maranhense,

137. a russo, a negro: ser um só, de todos,

138. sem palavra, sem filtro,

139. sem opala:

140. há uma cidade em ti, que não sabemos. ${ }^{342}$

1. Pedra por pedra reconstruiremos a cidade.

2. Casa e mais casa se cobrirá o chão.

3. Rua e mais rua o trânsito ressurgirá.

4. Começaremos pela estação da estrada de ferro

\footnotetext{
339 Antonio CANDIDO, op. cit., p. 17-18.

340 No poema "Canto ao homem do povo Charlie Chaplin", há uma imagem significativa do que seja o trabalho "poético":

222. Ó palavras desmoralizadas, entretanto salvas, ditas de novo.

223. Poder da voz humana inventando novos vocábulos e dando sopro aos exaustos.

341 Versos do poema "América".

342 Versos do poema "Canto ao homem do povo Charlie Chaplin".
} 
5. e pela usina de energia elétrica.

6. Outros homens, em outras casas,

7. continuarão a mesma certeza.

12. Mas o assombro, a fábula

13. gravam no ar o fantasma da antiga cidade

14. que penetrará o corpo da nova.

343 Versos do poema "Telegrama de Moscou”. 


\title{
DO DOIS AO TRESS,
}

\author{
EM SÍNTESE
}

\section{(CONCLUSÕES)}


O fundamento artístico de A rosa do povo é o dinamismo. Considerá-la em seus aspectos formais, ou ater-se à pluralidade de temas, ou, ainda, procurar a anterioridade de uma esfera sobre a outra, quaisquer dessas alternativas, em si, terminam por revelarse teórico-metodologicamente inadequadas, porque fixam, como significado último, uma ou outra dimensão de um complexo processo significante. Entre as referências ao real objetivo e a consideração do real lingüístico (propriamente simbólico, segundo a autonomia relativa da materialidade do texto), o que há na poética de A rosa do povo é uma subjetividade lírica que atua como potente fator de mediação e dinamismo. Ao figurar o texto como trabalho social, e ao incorporar a conjuntura objetiva à dinâmica simbólica do texto, o processo lírico faz imbricarem-se as dimensões do real objetivo e do real lingüístico, numa trama a tal ponto entrelaçada que termina por alcançar um outro plano de realidade, ainda dentro de um mesmo real, mas percebido e expresso de uma outra perspectiva, polissêmica, não mais convencional.

Não se trata de ruptura com o real objetivo; ao contrário, diferentes aspectos da reificação urbano-industrial, ou então a guerra, o nazi-fascismo e outros eventos conjunturais, terminam, por mimese, incorporados à realidade lingüística. Tampouco se trata de abandonar a densidade própria ao discurso poético, em que diversos níveis significantes (inclusive, mas não apenas, o da mimese) entrelaçam-se para compor um nível de significação polissêmico. Ocorre que, por um discurso propriamente poético, inserido, ele próprio, numa realidade, a um tempo, concreta (a materialidade do texto, a sua dimensão sincrônica, significante) e simbólica (porque a metalinguagem drummondiana figura o próprio discurso como ato social, diacrônico portanto, e historicamente situado), os eventos contextuais, diacrônicos, são transformados em significados multívocos, não mais unívocos, nem convencionais, enquanto os eventos da sincronia textual são desfeitos e refeitos, eles próprios, em suas convenções lingüísticas, e transformados em possibilidades semântico-sociais (trabalho desalienado) e lingüístico-formais (polissemia). O núcleo dessa transformação reflexiva, especular, é a subjetividade lírica, de que resulta a pluralidade de temas e de formas, cujo sentido último é a superação dessas duas realidades contextualmente apartadas (tema / forma), através da sua transformação numa terceira realidade, polissêmica: o significado poético (simbólico, em sua materialidade descoisificada). 
Isso quer dizer que o discurso drummondiano em A rosa do povo resulta do enfrentamento especular entre o real-texto e o real-contexto, estabelecendo-se um jogo complexo de imagens que, refletidas umas nas outras, projetam o texto no contexto e o contexto no texto, e terminam por incorporar, superando-a, a situação reificada de um real em que se apartam as realidades da produção e da reprodução da existência. O trânsito inevitável entre o real concreto e o real simbólico, tornado ideologicamente impossível pela organização do tempo social capitalista e pela linguagem nessa realidade mutilada, recupera o seu dinamismo, através das escolhas líricas. O dinamismo da subjetividade poética serve-se das possibilidades paradigmáticosintagmáticas para desfigurar os significantes e os significados pré-estabelecidos, mas nem por isso rompe com o nível da referenciação, porque, ao contrário, procura refazer o trânsito entre o que se diz e o como se diz, para redizê-los segundo a volição lírica, segundo as necessidades de um eu, situado em determinado contexto. Portanto, essa poética é libertária, não por apenas romper com os vínculos pré-estabelecidos entre o simbólico e o concreto, mas por refazê-los em termos polissêmicos, segundo os imperativos do desejo, da necessidade e da vontade. Numa palavra, as dimensões subjetivas e objetivas do real revelam-se, poeticamente, em sua realidade mais profunda, ainda que contextualmente encoberta: revelam-se integradas.

Por esse motivo, é equívoco descrever formalmente as situações lingüísticas em que, na aparência, o significado encaminha-se em direção ao hermetismo, se se desconsiderar o vínculo entre texto e contexto, projetando-se num dos níveis textuais drummondianos (a forma) um sentido que lhe é desconhecido (o formalismo). Assim procedendo, encaminha-se a interpretação das formas elípticas, ou paródicas, no sentido da intransitividade, da recusa à referenciação, quando, na verdade, a figuração do próprio discurso como trabalho social, em A rosa do povo, apenas comporta a reificação do signo poético (a redução do significante a coisa desprovida de possibilidades simbólicas, e a redução do significado à univocidade) como denúncia, que invariavelmente deverá transfigurar-se em possibilidades polissêmicas. Uma tal abordagem, que rompe unilateralmente com a relação entre texto e contexto, incansavelmente enunciada pela própria coletânea, e transforma, segundo pressupostos teóricos, o texto em coisa, tomando-o em si, em sua “concretude” dessubjetivada, desconsidera o fundamento poético de A rosa do povo, qual seja, o seu caráter processual, a integração que a subjetividade lírica drummondiana promove entre a diacronia da história e a sincronia da linguagem, temporalidades em realidade 
interdependentes, e que, em A rosa do povo, se transformam, mutuamente, num terceiro plano, o dos significados poéticos polissêmicos, fruto da volição lírica, que desfigura o real objetivo porque o reconsidera subjetivamente.

Da mesma maneira, é equívoco encaminhar a descrição das formas em que, aparentemente, há perda da densidade poética, no sentido de mostrar um segundo (supostamente antinômico) movimento discursivo: quando o envolvimento lingüístico é com a "política”, e não com a “poética”. De fato, a separação ideológica, no cotidiano urbano-industrial, entre os significados unívocos das situações “prosaicas” e a esfera “poética” da ressignificação é um tema importante em A rosa do povo, mas figurado como denúncia. Que há mimese da “divisão social do trabalho” entre a produção de significantes e a reprodução de significados, isto é fato em A rosa do povo, mas, quando isso ocorre, não se trata do significado último, mas de um entre outros níveis discursivos, que se entrechocam para tornar polissêmicos os significados, ressignificando-os. O ostracismo da estética, no mundo capitalista, como algo apartado da política e do trabalho, não é algo em conformidade com a poética de A rosa do povo, senão como denúncia. A rosa do povo logra superar essa dimensão contextual, através da capacidade metalingüística do seu texto. Esta é a verdadeira dimensão "engajada” da poética de 1943-1945, na medida em que incorpora uma problemática contextual ao plano, a um tempo simbólico e concreto, do texto, não como coisa, mas como mediação entre a objetividade das coisas e a subjetividade volitiva.

Em última instância, a realidade complexa de $A$ rosa do povo, o seu caráter processual, desencoraja qualquer abordagem que não se sirva de recursos teóricometodológicos integrativos. Intuir que a política é uma dimensão fundamental em $A$ rosa do povo não garante a sua demonstração analítica; ao contrário, ao abordar a problemática, invariavelmente se constata o quanto a questão coletiva não prescinde, antes pressupõe, a radical subjetividade. É preciso notar, entretanto, que os momentos de subjetividade mais radical, em que, paradoxalmente, a intensidade emotiva é tão grande que parece implicar a elipse quase total do sujeito lírico, representam, na verdade, a subjetivação da política em graus paroxísticos, enquanto os momentos de aparente dissolução do eu numa coletividade que o contém mas transcende, ao contrário, apontam para questões muito íntimas e muito líricas. A pluralidade de temas e de formas resulta do deslocamento incessante da subjetividade em direção ao próprio eu ou, então, ao outro e ao mundo; em quaisquer desses percursos poéticos, entretanto, o sentimento lírico é sempre o da insuficiência, o que, em vez de paralisar o movimento, 
torna-o, ao contrário, mais intenso. Por sob a desfiguração do eu, ou por sob a desfiguração do outro, ou do mundo, encontra-se, invariavelmente, um mesmo personagem, expresso, entretanto, por diversas personae, e em múltiplas situações líricas (invariavelmente líricas). A síntese, ou a superação, das dimensões do real ideologicamente apartadas (subjetividade / objetividade) se faz pela incorporação do texto ao contexto (pela metalinguagem) e da incorporação do contexto ao texto (pelo adensamento do discurso).

Não por acaso, nota-se que os elementos do discurso poético (eu, tu, mensagem e meio), e os seus recursos fundamentais (sonoridade, metro, ritmo etc.) tornam-se incessantemente figuras da poética drummondiana de A rosa do povo. O discurso, dessa forma, não tem realidade em si, apenas na situação dinâmica do ato discursivo. Em outras palavras, o discurso explicita a sua própria realidade processual, daí desqualificar-se a si próprio como "precário", quando tomado em absoluto, como coisa. A poética drummondiana em A rosa do povo procura explicitar-se como ato volitivo em determinado contexto, jamais restrito a "objeto de palavras", mas vinculado a uma situação discursiva, em que autor e público concorrem para a construção do significado, em determinado contexto, com vistas a transformá-lo.

Como fragmentos formais, ou como significados parciais, os momentos líricos drummondianos, incontáveis, não encontram realidade suficiente. São como diversas manifestações de uma mesma personagem, insuficientes em si mesmas, dependentes de seu contexto mais amplo: a “obra” (não como “objeto de palavras”, mas como ato discursivo). Parafraseando Alcides Villaça, podemos dizer que o sujeito lírico drummondiano é um sujeito de muitas faces, verdadeiro em todas e incompleto em cada uma.

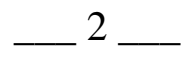

A proposta inicial deste estudo precisou reformular-se. Tendo como problemática central a questão do engajamento, e objetivando abordá-la, não a partir de um recorte exclusivamente temático, mas de acordo com a organização da expressividade, entendemos que a lírica de guerra, ou os demais poemas considerados militantes, não esgotavam o envolvimento poético com as questões políticas. A 
representação do tempo, fosse nos poemas explicitamente engajados, fosse em poemas mais subjetivos, implicava o "tempo presente" como escala figurativa, como recurso importante para a representação do "sentimento do mundo", uma escala a partir da qual construíam-se os movimentos líricos em direção à memória, às projeções volitivas ou, então, a uma contemporaneidade interdita, e ao seu combate. Tendo o "tempo presente" como escala, a temporalidade poética se desdobrava numa riqueza de outros tempos, sem, no entanto, jamais resvalar no heróico, no monumental ou em experiências estranhas ao vivido e ao indivíduo. O “tempo presente", como escala do "sentimento do mundo”, parecia assumir a forma da experiência do indivíduo no dia-a-dia, ainda que não restrita ao universo reificado do trabalho ou do descanso, porque aberta, também, ao devaneio, à interioridade, à memória e, mesmo, às inversões do tempo ordinário, do cotidiano urbano-industrial. O “tempo presente”, ao figurar-se num desdobramento pleno de possibilidades temporais, denunciava, explicitamente, alusivamente ou, ainda, como uma espécie de "sentimento íntimo", as interdições do mundo contemporâneo, tanto as de natureza subjetiva como as de natureza objetiva, e essa figuração, entretanto, encaminhava-se no sentido da transfiguração, graças à potência expressiva da volição lírica.

Essa escala temporal, como núcleo tanto dos momentos denotativamente engajados quanto dos demais momentos da experiência lírica, revelava-se uma dimensão expressiva capaz de integrar, analiticamente, diversos momentos da poética drummondiana, e, nesse sentido, o seu estudo poderia revelar aspectos importantes da participação poética, em termos de elementos propriamente textuais, na dimensão extraliterária do contexto. Metodologicamente, contudo, ainda que se pudessem descrever diferentes momentos temático-formais do lirismo de A rosa do povo, uns mais subjetivos, outros predominantemente referenciais, e ainda que fosse possível demonstrar o "tempo presente" da experiência poética, a funcionar como uma escala figurativa em todos eles, o vínculo coesivo entre os momentos poéticos os mais diversos não se podia definir por esse caminho, sob pena de desconsiderar a coerência poética do livro, qual seja, a pluralidade de temas e de formas.

Entre a lírica de guerra e os poemas aparentemente herméticos, ou os poemas que tratam da identidade lírica por meio de evocações mnemônicas de natureza autobiográfica, ou por meio da consideração figurativa da finitude do indivíduo, as mais variadas experiências temático-formais não se caracterizavam, em A rosa do povo, senão como pluralidade. O único vínculo entre essas experiências multívocas, capaz de 
explicar a sua coesão, e do qual, inclusive, derivava o vivido como escala figurativa, remetia à especificidade do lirismo drummondiano, e, nesse sentido, a tese de Antonio Candido, no ensaio “Inquietudes na poesia de Drummond”, revelou-se fundamental.

É ao plano do lirismo que se deve recorrer para a compreensão de quaisquer aspectos da obra drummondiana entre 1935 e 1959, o que inclui, evidentemente, a coletânea de 1943-1945. Sem a compreensão das especificidades da lírica drummondiana, os aspectos da sua poética tendem a revelar-se descontextualizados, e, como fragmentos, tendem a induzir ao equívoco interpretativo. A tese de Antonio Candido, porque resulta de uma compreensão teórico-metodológica de natureza integrativa, logra alcançar a dinâmica poética drummondiana em sua riqueza de temas e de formas, derivadas de um núcleo temático precisamente descrito como as “inquietudes” de uma "subjetividade tirânica”.

O dinamismo dessa subjetividade lírica, entre aspectos da interioridade e da exterioridade permanentemente tensionados, motivado pela percepção da insuficiência mútua e pelo desejo, igualmente bitransitivo, de redenção, eticamente envolvido com o pensamento socialista, leva à desfiguração da expressividade, que se vê refeita em termos polissêmicos. Por isso, a coerência dessa poética, que se assenta no conflito e que resulta na multiplicidade temático-formal, remete à coesão lírica, em que o indivíduo, paradoxalmente plural, logra alcançar a redenção do mundo pela radicalidade lírica, e a redenção do indivíduo lírico pelo "sentimento do mundo”.

Tendo em vista esse contexto, a um tempo literário e engajado nas questões contemporâneas, é possível compreender quaisquer aspectos da lírica drummondiana: como elementos dinâmicos de um processo poético, fundamentado na radicalidade lírica. O elemento expressivo, em que a coesão poética do lirismo e a coerência de sua pluralidade temático-formal se revelam, de modo integrativo, é, ainda segundo Antonio Candido, a metalinguagem.

Seguindo essa tese das “inquietudes” é que recolocamos, então, o nosso problema de pesquisa. Com vistas a reavaliar o engajamento, não mais como um tema entre outros, mas como parte integrante do dinamismo lírico, de natureza, a um tempo, estética e política, recortamos alguns metapoemas fundamentais. A análise de seus aspectos figurativos deveria encaminhar a demonstração de nossa hipótese no plano da expressividade. Alcançando o fundamento lírico da poética drummondiana em A rosa do povo, tornar-se-ia metodologicamente possível, então, compreender a organização da expressividade segundo o envolvimento com questões contextuais, visando a investigar, 
em seguida, alguns percursos poéticos, segundo preocupações predominantemente temáticas.

Por isso, investigamos com maior vagar, no primeiro capítulo, o primeiro poema de $A$ rosa do povo, que, sob o tom de manifesto, figura-se um verdadeiro microcosmo poético da coletânea. Nele, o texto, figurando a si próprio, incorpora múltiplos aspectos contextuais. O "verso", metonímia de todos os recursos fundamentais da expressividade poética, torna-se, por metalinguagem, a figura do próprio lirismo, desfigurado como convenção lingüística e posto ao serviço, por recorrer a um discurso propriamente poético (isto é, denso, complexo), da volição lírica, em sua problemática libertária. E essa subjetividade poética, figurando a si mesma, só se completa pelo recurso à interlocução. Portanto, além dos recursos fundamentais da expressividade poética, tornados figura por metalinguagem e por metonímia, o próprio discurso poético representa a si próprio, não como texto, apenas, mas como ato discursivo, do qual, além do texto, participam, igualmente figurados, o autor e o público, situados em contextos precisos.

Nesse poema-poética, a figuração dos recursos fundamentais do poema e dos elementos do discurso comportam uma espécie de justaposição de fragmentos expressivos, de tal modo que a coerência do poema não se pode identificar senão em termos duma pluralidade vertiginosa, em que o texto, estruturado em relações metonímicas, exige a sua contextualização na obra drummondiana mais ampla, remetendo, inclusive, aos poemas da primeira coletânea de Drummond (Alguma poesia, de 1930, notadamente o "Poema de sete faces" e o emblemático "No meio do caminho”). E esse contexto amplia-se ainda mais, com as alusões a diálogos (de fato, praticados, ao longo deste e de outros poemas) com o movimento das vanguardas poéticas no Brasil, na América Latina e na Europa, diálogos que implicam, sobretudo, a incorporação do leitor (figurado como um tu) ao processo ativo de construção do significado poético.

O sentido das características formais, que procuramos analisar e interpretar em profundidade, no primeiro capítulo, terminam por caracterizar a poética de todo A rosa do povo, tomado como obra ou como momentos particulares, nela inseridos, como procuramos demonstrar na Primeira Parte do nosso trabalho. Há, em A rosa do povo, uma subjetividade lírica que, ao transitar pelas dimensões interiores ou objetivas do real figurado, recorre à metalinguagem como forma de desfigurar as suas percepções, refazendo-as no plano de uma expressividade, cujo sentido último é a redenção. Para 
tanto, os recursos expressivos e o próprio discurso, segundo a escala lírica da experiência individual no tempo desalienado do vivido, transformam a situação lírica em ato social, superando, com isso, a separação reificada entre significante e significado, e entre objetividade e subjetividade.

A justaposição de fragmentos que, em si, não encontram sentido pleno, mas que, inter-relacionados e contextualizados, permitem a construção de sentidos polissêmicos, segundo a escala lírica do vivido e do indivíduo, constitui o sentido temático-formal, não apenas do primeiro texto de A rosa do povo, mas de toda a vertiginosa pluralidade de experiências poéticas, as mais diversas, de toda a coletânea. Vistos como realidades suficientes em si, apartadas do contexto da coletânea à qual pertencem ou, ainda, do contexto extra-literário no qual explicitamente se engajam, cada um dos poemas perde grande parte da sua realidade literária. Apenas quando entendidos como movimentos de uma subjetividade lírica que remete a um sempre mesmo personagem, muito embora em diversos momentos discursivos e sob diversas personae, apenas dessa perspectiva é que os poemas alcançam o sentido para o qual já “Consideração do poema” apontava, qual seja, o da superação dos estados reificados, em que o universo objetivo do real encontrase interdito, diante das subjetividades.

No segundo capítulo, procuramos demonstrar, através da interpretação de “Procura da poesia”, que a proposta de “Consideração do poema” encontra, no segundo poema de A rosa do povo, um desdobramento de natureza dialogal. Os dois primeiros poemas do livro, aparentemente contraditórios, mas, em realidade, complementares, constituem chaves de leitura, indícios de abordagem para os demais percursos líricos da coletânea, insistindo em sua realidade dinâmica, processual, descoisificada (que encontra, na ausência de seções, a sua expressão estrutural mais adequada).

Com essa hipótese em mente, no terceiro capítulo, em vez de abordar cada poema, objetivando extrair, por uma leitura detida, uma concepção da poética drummondiana em A rosa do povo, passamos a interpretar aspectos de três poemas, com o intuito de compreender, de maneira articulada, a imagem que, talvez, seja a mais importante da coletânea: a da "flor", cujo sentido, também metalingüístico, deveria confirmar as características líricas depreendidas no primeiro capítulo e no segundo (a coerência na pluralidade de temas e de formas e a coesão na especificidade lírica drummondiana). Nesses termos, o terceiro capítulo ainda não estabelecia uma leitura de crivo temático, porque a "flor” configuraria, menos um tema, e mais uma imagem metapoética. 
Em suma, os três capítulos, que compõem a Primeira Parte desta pesquisa, procuraram investigar o fundamento do lirismo drummondiano em A rosa do povo, inspirados pela tese das "inquietudes" proposta por Antonio Candido (se bem a entendemos) e com vistas a compreender, no plano da expressividade, a que ponto o engajamento, isto é, a participação da subjetividade lírica na problemática contextual, contribui para a organização da sincronia lingüística (a materialidade do texto). Com esse objetivo, procuramos refutar a idéia de que há, em A rosa do povo, uma oscilação, de natureza pendular, entre a participação estética e a participação política, quando, na verdade, podemos concluir que o lirismo drummondiano logra superar aquela separação reificante, de fato presente no contexto extra-literário, mas que, uma vez incorporada ao texto, pertence, como mimese, a um dos momentos, certamente não o último, da construção do significado poético.

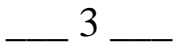

Após o esforço por compreender, de modo integrativo, o dinamismo poético de A rosa do povo, procurando demonstrá-lo na leitura analítica de momentos poéticos importantes da coletânea, devidamente contextualizados, arriscamo-nos a acompanhar alguns percursos líricos, em que a "temática” do engajamento pudesse ser abordada. Para evitar a armadilha de um recorte que perdesse de vista o dinamismo entre coesão (a escala lírica) e coerência (a pluralidade temático-formal), insistimos, ainda uma vez, e de maneira mais intensiva, em caracterizar a especificidade do lirismo drummondiano, e, para tanto, apropriamo-nos do conceito de gauchismo, proposto inicialmente por Affonso Romano de Sant'Anna, mas refinado ensaisticamente por Alcides Villaça. Segundo a nossa perspectiva, o conceito das inquietudes líricas, de Antonio Candido, ganha em somar-se ao conceito de gauchismo, refinado por Villaça, permitindo compreender, seja num mesmo poema (como no "Poema de sete faces”, ou no “Consideração do poema”, que de certo modo o retoma e amplia), seja nos diálogos que se podem estabelecer entre diversos poemas numa mesma coletânea ou em coletâneas diversas (o que o próprio lirismo drummondiano de A rosa do povo encoraja), as várias “faces”, ou personae, drummondianas, não como realidades suficientes em si mesmas, 
nem como fragmentos que, ao contradizerem-se, anulam-se, mas como desdobramentos de uma mesma identidade, propriamente complexa e integrada.

Assim sendo, no capítulo 4, procuramos interpretar a lírica de guerra, não em seus aspectos referencialmente "políticos” (isto é, sem destacar, do texto, menções ao contexto), mas, num movimento contrário, procurando focar os seus aspectos propriamente “estéticos” (isto é, a incorporação de elementos contextuais por recursos textuais), e constatamos que a figuração dos “eventos” traumáticos se expressa, naqueles poemas, por uma subjetividade bastante significativa. Não se trata, como muitas vezes se tem apressadamente constatado, de referências de tipo "prosaicas” ao Nazi-fascismo ou à Resistência, e sim de uma espécie de insulamento subjetivo, de um discurso lírico em que a emotividade, ou traz indícios de isolamento, diante das interdições de um real objetivo, ou expressa alívio diante de uma interdição até há pouco inominável, mas que, agora, começa a delinear-se sob a forma do nome, porque, paradoxalmente, começa a degenerar como elemento de realidade objetiva. Em suma, não se trata de referenciar, por uma comunicação pouco mediada, um real, mas, ao contrário, trata-se de desfigurar uma realidade através do adensamento do discurso, notadamente através de uma marcada consciência lingüística, com recurso ao metalirismo. E esse percurso de adensamento lingüístico passa, necessariamente, pelo gauchismo drummondiano, isto é, pelo dinamismo inquieto da subjetividade lírica, que mimetiza a interdição no universo da subjetividade para, escavando-a, transcender as suas insuficiências.

Entre a percepção do real interdito e a sua transfiguração, é possível notar, em $A$ rosa do povo, um percurso lírico que vai do trauma à sua superação, através do ato de nomear o evento traumático. Nesse sentido, o “engajamento”, ou a participação do lirismo em questões coletivas, implica, em vez de recusá-la, a interioridade subjetiva. A figura do exílio da subjetividade, diante das interdições do real, em vez de romper com o contexto (isolando a expressividade num movimento "mallarmeano”, ou hierático, isto é, hermético, auto-referencial), é, ao contrário, uma forma liricamente eficaz de denunciar o absurdo de uma conjuntura diante da qual nenhuma forma de representação realista ou confessional é aceitável, sob o risco de banalizá-lo.

Evidentemente, esta é uma interpretação, e que assume explicitamente a necessidade de situar cada um dos poemas de 1943-1945 em seu contexto devido, não como um ato arbitrário, mas em respeito às próprias sugestões poéticas, porque, de resto, a expressividade drummondiana requer a intervenção leitora como recurso 
necessário à construção do significado, sem o qual o processo literário não se completa, enunciando-se "precário”. De todo modo, por sob as personae da subjetividade lírica, insuficientes em si mesmas, encontra-se um percurso que escava o autobiográfico em direção a diálogos, os mais diversos, com o "tu” do discurso, lugar por sob o qual cabem outros poetas e escritores, cineastas, gente do povo e, sobretudo, o leitor.

Assim é que, no percurso lírico, que identificamos no capítulo 4, e que inclui a figuração do contexto traumático em diversos momentos líricos, desde as situações absolutamente inomináveis até à superação do trauma (renomeado), o que se vê não é a mera referenciação, pouco mediada, de elementos contextuais (linguagem que se poderia conceituar como “prosaica”), mas, ao contrário, uma intensa mediação, pelo lirismo metapoético drummondiano, do contexto, segundo recursos textuais competentes, que exprimem aspectos de uma conjuntura interdita através de uma subjetividade inconformada e de uma linguagem transfiguradora, em tal grau complexa que configura um verdadeiro sistema de pensamento, e que representa, no plano da forma, a politização da subjetividade como aspecto contextual, transfigurado, entretanto, literariamente.

Já no capítulo seguinte, o percurso lírico que se busca interpretar é inverso. No lugar dos eventos traumáticos, nomeados pela subjetividade e, com isso, transfigurados, o que se percebe é a superação de aspectos objetivos pela projeção, a um tempo volitiva e cognitiva, da integridade lírica. Portanto, em vez de projetar-se o mundo traumático na interioridade lírica, é a integridade lírica que reorganiza a objetividade fragmentária. Mais uma vez, em meio a uma vertiginosa pluralidade de aspectos temático-formais, a coesão do discurso encontra-se no gauchismo drummondiano, mas, agora, o percurso das manifestações diversas do psiquismo gauche, em vez de revelar a politização da subjetividade, ao contrário, revela a subjetivação da política.

Em vez de o mundo coisificado do capital imiscuir-se na interioridade subjetiva, estraçalhando-a, é a integridade lírica que, inversamente, se projeta, como construção psíquica, no universo dessubjetivado das coisas, dos objetos, tornados mercadoria pela lógica reificada do capital mas, agora, reintegrados aos aspectos volitivos do psiquismo 
lírico, tornando-se polissêmicos. O "tempo", organizado socialmente pelo ethos fragmentário da propriedade privada dos meios de produção, desfigura-se nas projeções da vontade lírica, sob a forma da memória, da finitude e do desejo, integrando as mais variadas dimensões do eu a uma temporalidade múltipla, cuja escala é a experiência integral do indivíduo.

Ao desfigurar, numa aparente descritividade, um tempo-espaço dilacerado pelo ethos da divisão social do trabalho, da despersonalização e do belicismo, representado pelas figuras do medo e da noite, o Gauche não se resigna à escala sociológica da luta de classes. O papel social, dimensão importante na construção identitária do eu, não esgota, no gauchismo drummondiano, o universo do psiquismo, cuja temporalidade integra, à produção e à reprodução da existência, uma inesgotável pluralidade de dimensões, concretas como também simbólicas, que recolocam o real subjetivo do indivíduo diante do real objetivo e de outras subjetividades.

Não se trata de recusar a dimensão de fato reificada de uma realidade impermeável às dimensões individuais do desejo, da necessidade e da vontade; tampouco se trata de apenas desfigurar essa realidade, segundo um projeto exclusivamente político, igualmente impermeável ao indivíduo (ou, por outra, igualmente reificado). As questões políticas, ao considerarem a objetividade do real e os limites materiais da existência, não esgotam as necessidades subjetivas, muito embora componham um dos níveis fundamentais do projeto lírico. Em si, as questões políticas, bem como as sociológicas e as demais questões “objetivas”, são tão necessárias quanto, em si, insuficientes. Apenas quando reintegradas a um projeto mais amplo, cuja escala é a experiência individual em suas múltiplas necessidades, tanto as mais diretamente vinculadas ao real objetivo quanto aquelas de natureza mais íntima, e nem por isso menos reais - apenas dessa perspectiva temático-formalmente plural é que o ethos fragmentário do capital se vê transfigurado pelo lirismo drummondiano.

Ainda que o plano mimético do gauchismo drummondiano n’A rosa do povo revele uma aguda capacidade cognitiva de compreender a realidade urbano-industrial, representando-a fragmentariamente, o sentido último dessa representação é condenar o seu ethos. Portanto, diferentemente do que a descritividade denotativa possa sugerir, não é a compreensão do fenômeno, ou a sua denúncia, o sentido último do engajamento drummondiano, mas a condenação do seu princípio, da escala segundo a qual o fenômeno se reproduz, como algo estranho e nocivo à condição íntegra e integrativa da experiência individual. 
Evidentemente, não se trata de uma perspectiva filosófico-existencial como sentido último do ethos drummondiano, porque essa "condição humana”, ou melhor, essa “contingência”, percebida como essencialmente mutável, não é de ordem ontológica, mas histórica. O humano, no Drummond de A rosa do povo, consiste em que as necessidades do indivíduo, indefiníveis em absoluto, e em bases invariavelmente materiais, sofram a mediação do simbólico, para que se satisfaçam segundo os planos subjetivos do desejo e da vontade, sem com isso negar, antes reforçando, a sua condição finita e material, isto é, mortal, não transcendente em termos absolutos, mas relativa, mutável.

Por sob a desfiguração do ethos fragmentário do capital, portanto, contrapõe-se o ethos integrativo do gauchismo drummondiano, cujas preocupações comportam o papel social e as questões políticas, sem, contudo, resignar-se a elas. A escala radical da individualidade lírica, ao contrapor-se à objetividade enrijecida e unívoca do panóptico urbano-industrial, garante a experiência do indivíduo em sua inteireza e concretude, avessa à abstração da subjetividade, desidealizada, contrária à massificação e a outras experiências despersonalizantes, cuja escala esvazia o trânsito da subjetividade à objetividade e, com isso, empobrece o real.

Como se vê, ao transcender-se a dimensão política da experiência urbanoindustrial, isto é, ao historicizar-se a dimensão coletiva num contexto cuja escala transcende o indivíduo, empobrecido em sua subjetividade, transformado em instrumento do real objetivo, a política não se vê referenciada como algo préestabelecido, mas ressignifica-se como algo objetivamente pertencente à experiência de uma pólis concreta, cuja escala precisa refazer-se, para comportar a volição lírica. Não se trata de reduzir o humano ao político, mas de redimensionar diversos aspectos objetivos (políticos, inclusive) segundo necessidades humanas mais fundas, historicamente situadas, e por isso mesmo mediadas pelo simbólico e pelo volitivo, em sua realidade e concretude. Por isso, quando se fala em “engajamento” drummondiano, é preciso perceber, pela construção do significado poético, que não se trata simplesmente de fazer com que a problemática contextual se sirva de um discurso pouco mediado, mas, ao contrário, trata-se de ressignificar a problemática contextual segundo o adensamento de um discurso cuja natureza é a radicalidade subjetiva do indivíduo lírico.

No Drummond de A rosa do povo, ainda que o discurso tome partido da Resistência sob a perspectiva militante do socialismo, contrária ao nazi-fascismo e 
simpática ao marxismo-leninismo, o referencial do significado poético, muito embora não se encontre exclusivamente na materialidade do texto, tampouco se resigna à mimese pouco criteriosa do contexto. E, com isso, em vez de o pensamento poético esvaziar-se em razão do engajamento político, é a militância que, inversamente, se vê enriquecida pela perspectiva densa de um discurso polissêmico, com seu ethos muito particular, potentemente lírico.

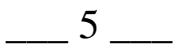

Segundo o conceito de “inquietudes”, é possível compreender que a pluralidade vertiginosa de temas e de formas, em A rosa do povo, resulta de um dinamismo subjetivo que, direcionado às questões do eu, refigura o mundo, e que, encaminhando-se à problemática do mundo, reencontra a complexidade interior, sob perspectivas diversas. Eu, Outro e Mundo entrelaçam-se na dinâmica literária, nunca suficiente, implicando um incessante deslocamento entre objetividade e subjetividade, que tem como núcleo as inquietudes líricas.

O núcleo dinâmico desse eu todo-retorcido não se refere, entretanto, ao universo imediato das percepções. A desconfiança, que está na base da relação entre interioridade e exterioridade, dirige-se também, e sobretudo, à própria percepção, insuficiente como registro, mas também como expressão, de maneira que

... o trabalho poético produz uma espécie de volta ou refluxo da palavra sobre a idéia, que então ganha uma segunda natureza, uma segunda inteligibilidade. Tanto assim, que o poema é geralmente feito com o lugar-comum (...). Nas mãos do poeta o lugar- comum se torna revelação, graças à palavra na qual se encarnou. ${ }^{344}$

A partir dessa perspectiva é que procuramos investigar a temática do engajamento, não como um assunto, nem como a referenciação pouco mediada de eventos (à suposta maneira da crônica), mas como um dos fundamentos artísticos de $A$ rosa do povo, necessariamente integrado às inquietudes líricas. Assim, interpretamos, em alguns percursos do Gauche, aspectos do mundo em sua subjetividade retorcida, e

344 Antonio Candido, “Inquietudes na poesia de Drummond”, in Vários escritos, p. 140. 
aspectos objetivos, refeitos pelo gauchismo de sua percepção, de tal modo que esses fragmentos temático-formais, respeitados em sua pluralidade, fossem entretanto compreendidos no contexto da integridade lírica, contexto a um tempo sincrônico (a obra como manifestação literária, lingüisticamente estruturada) e diacrônico (a obra como discurso, escrita num determinado contexto, explicitamente figurado, e redimensionada segundo infinitos contextos de leitura).

Como o dinamismo lírico do Gauche compreende

... de um lado, a preocupação com os problemas sociais; de outro, com os problemas individuais, ambos referidos ao problema decisivo da expressão, que efetua a sua síntese $e^{345}$,

o nosso sexto capítulo perseguiu a figura do “canto” em diversos momentos poéticos de A rosa do povo, e verificamos, no plano temático-formal, que o metalirismo, de fato, encaminha-se no sentido de superar as convenções (tanto em termos de significados sociais quanto em termos de significação lingüística), permitindo, assim, que a percepção e a expressividade, revigoradas, efetuem a redenção de eu e mundo.

Nesses termos, participam da obra, como figuras, o “eu” (dimensão autoral), o "tu” / "vós” (formas dialogais), o “meio" (ou contexto discursivo) e a "mensagem" (que, mais do que o "texto", é o ato discursivo de construir significados, pela interação simbólica, possível ou interdita, entre “eu” e “tu”, num determinado “meio”), e é a partir da interação dessas figuras no metalirismo drummondiano que, por diversas vezes, e em diversas situações, figura-se o próprio “canto”. A figura do “canto”, em A rosa do povo, não é um objeto feito de palavras, nem apresenta um significado ontologicamente definível, mas é algo que se faz e refaz segundo situações “concretas”, e, em determinado "contexto", enuncia-se incapaz de construir significados, reduzindo-se a significantes, mas, em outros “contextos”, logra superar as interdições da "noite” sob a imagem da "aurora”. Em quaisquer situações, contudo, o “canto" invariavelmente representa a si próprio como ato, o que escapa à pura sincronia do “texto”, sem reduzirse a mero apêndice dos “fatos".

Mais do que a figura do "canto" denotada, a sua construção, indiscutivelmente poética, serve-se de um discurso tão denso e especular que, independentemente de o seu enunciado recorrer à função conativa explícita, ou, então, à chamada personificação

\footnotetext{
345 Idem, ibidem, p. 112.
} 
literária (quando o “eu” drummondiano se desdobra num “tu” e, sob a forma do diálogo, o que ocorre é, mesmo, um solilóquio), a situação metapoética será, ao fim, profundamente dialogal, de tal maneira que “eu”, “tu”, “meio” e “mensagem”, inevitavelmente, se entrelaçam num ato discursivo, sendo esse o sentido último, e polissêmico, do “canto”, não importa se o enunciado, elegíaco, se refere à “noite”, ou se, eloqüente, se refere ao "amanhecer".

É possível que o “canto” assuma a aparência narcísica da confissão autobiográfica, sob um pathos exaltado ou, então, sob uma marcada despersonalização, e, num caso ou no outro, trata-se do redirecionamento, indiscutivelmente sob formas líricas, da identidade no sentido da alteridade. Como se trata de um lirismo muito específico, metapoético, o “canto”, polissêmico, dialogal, quanto mais radicalmente lírico, mais imprime, aos aspectos autobiográficos, uma importância heterobiográfica, em razão duma consciência formal que transforma a capacidade significante em algo completamente desprendido das convenções, não apenas conceituais, mas sobretudo lingüísticas.

O “canto”, em seus aspectos de “mensagem”, recorre a diversas aparências: ora assume a tonalidade da "crônica”, ora a forma do "manifesto", ora, parodicamente, ironiza alguma convenção “poética”, e, em outros momentos, o tom é o do "ensaio”, chegando, mesmo, a assumir preocupações “monográficas”. Um dos sentidos disso é transfigurar, pela prática discursiva, as convenções sobre o próprio fazer literário, recuperando a sua capacidade de exprimir um real historicamente específico. Transformar a sua dimensão simbólica é, de alguma forma, recuperar a capacidade individual, cognitivo-volitiva, diante duma realidade que se quer ahistórica, porque supostamente imutável.

Cabe lembrar, também, que o diálogo entre os textos "poéticos” de A rosa do povo e os textos "prosaicos” de Confissões de Minas, longe de resultar apenas do arbítrio interpretativo, vem sugerido pela própria persona do autor, já nos planos dos enunciados. De resto, o ensaio “Drummond prosador”, de Antonio Candido, já apontara a impertinência de separar a obra drummondiana segundo convenções de gêneros, quando a sua realidade literária as torna obsoletas, porque as transfigura.

Portanto, a participação poética, n’A rosa do povo, está longe de restringir-se à "lírica de guerra” ou ao "bloco do engajamento", porque, mais do que referenciar os fatos, o "sentimento do mundo", ou a percepção da historicidade, transforma a diacronia através dos próprios recursos literários, ressignificados pelo metalirismo gauche. A 
poesia drummondiana, com não ser historicista, não perde em historicidade, tampouco enfraquece o "poético", ao aproximar-se do "prosaico"; nela, os “eventos” não são, exclusivamente, os "fatos", que se transformam, liricamente, através de um "sentimento íntimo”, propriamente literário, com o recurso a uma linguagem "poética” (porque densa), que não resvala, em definitivo, nem no hermetismo, nem no formalismo.

A capacidade lingüística do lirismo drummondiano, em refletir sobre a sua própria realidade simbólica, inserindo-se no real mais amplo como trabalho social significante, serve-se de uma inserção contundente nos eventos históricos (não no sentido historicista, factual), resultante duma potência lingüística que, em vez de empobrecer-se com o engajamento, ao contrário, ressignifica o próprio ato de engajarse, enriquecendo-o lingüisticamente.

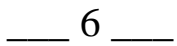

Podemos concluir que a poética de $A$ rosa do povo assenta-se num complexo dinamismo entre texto e contexto, mediado por um lirismo muito específico. Essa mediação transforma por completo as realidades, em princípio autônomas, de história e linguagem, mesmo porque há, na coletânea, uma consciência muito clara do quanto essa autonomia é, de fato, relativa. Ademais, o desejo lírico de que se redimam ambas as realidades, contextualmente apartadas, por sua reintegração a um mesmo real, compõe um dos fundamentos do dinamismo poético. A especificidade da lírica drummondiana de 1943-1945 é uma subjetividade que não se propõe como horizonte o mero registro de uma realidade reificada, tampouco a sua transfiguração por meios de recursos meramente imaginativos. O que a subjetividade drummondiana restabelece é o trânsito orgânico entre as dimensões objetivas e subjetivas do real, através de uma escala figurativa que remete à experiência integral do indivíduo e através de uma linguagem que se refaz incessantemente como ato social integrativo.

A grande dificuldade, no estudo de A rosa do povo, é fugir ao recorte, ou só temático, ou só formal, uma vez que essas opções metodológicas tendem a perder de vista o elemento de mediação entre as dimensões textuais e as dimensões contextuais, e, assim, tendem a estabelecer como significado último de cada poema, ou de toda a coletânea, uma das suas dimensões significantes, ou um conjunto fragmentário de 
significados desiguais, porque pouco, ou nada, integrados. Ao descrever, analiticamente, aspectos do estilo, por exemplo, é possível alcançar uma pluralidade de manifestações estéticas que, em si, pouco tendem a contribuir à interpretação, a não ser sob a forma de conceitos e juízos (ou preconceitos e prejuízos) alheios à realidade da obra, que terminam por se mostrar, antes, projeções e sobreposições imediatas do contexto crítico por sobre o contexto artístico objetivado. Por outro lado, a seleção de aspectos contextuais, como a guerra, parte de um pressuposto que não só é alheio ao livro, mas nocivo à sua compreensão: a separação entre eventos “objetivos” e “subjetivos”, “lingüísticos” e “extra-lingüísticos”, predominantemente "prosaicos” ou predominantemente “poéticos”.

O que ocorre na coletânea, através das inquietudes líricas do gauchismo drummondiano, é o enfrentamento entre subjetividades diversas e aspectos do mundo objetivo, entrelaçados por uma escala lírica que se serve da linguagem como forma de conhecimento e de volição, e que termina por superar uma realidade fragmentária. Em A rosa do povo, portanto, a "linguagem", representada pelo metalirismo como figura, transcende os seus sentidos contextualmente reificados, como forma de restabelecer a capacidade de mediar as dimensões do real que, naquele momento, apresentavam-se apartadas. Não por acaso, é no recurso à metalinguagem que a coletânea logra integrar aspectos contextualmente antinômicos, mas que, no texto drummondiano, logram alcançar, em termos de síntese, a sua superação.

O ensaio de Antonio Candido "A passagem do dois ao três" ${ }^{346}$ observa que a proposição das categorias “natureza” e “cultura”, como instrumentos estruturais de análise do romance $O$ Cortiço, de Aluísio Azevedo, demonstra-se interessante, mas compromete o salto da análise à interpretação, ao desconsiderar que a problemática, corretamente identificada em elementos textuais, requer que se encontrem as mediações necessárias entre os planos do texto e do contexto, sob pena de tomar como "natural”,

\footnotetext{
346 Antonio CANDIDO, “A passagem do dois ao três”. In Revista de história, 1974, vol. L, tomo II, p. 787-800.
} 
no plano do texto, o que é, nele próprio, de ordem sócio-econômica, ainda que, mediado por elementos ideológicos, tenda a apresentar-se de modo naturalizado.

Se a figura do cortiço equivale, na representação, a um meio / natureza em que o trabalho constitui um fator de degradação do homem, enquanto a figura do sobrado equivale à conquista da cultura, pela desnecessidade do trabalho e o alcance do ócio, e se o plano do texto denuncia a ascensão social de determinados personagens por sua relação degradada com o trabalho próprio e alheio, o salto interpretativo requer que se identifique o significado do trabalho numa sociedade escravista, a organizar aspectos do texto pela mediação do escritor, situado naquele contexto sob a perspectiva de "homem livre” (de algum modo “ocioso”, portanto tendo uma auto-imagem mais próxima do sobrado / cultura que do cortiço / natureza).

É nesse sentido que não se questiona, no plano interno da obra, o fundamento sociológico da exploração de uma classe por outra, mas condena-se, etnicamente, a ascensão social do "português”, apenas provisoriamente animalizado, graças ao próprio trabalho mas, sobretudo, à exploração astuciosa do elemento "nacional” (este, sim, permanentemente condenado à degradação do cortiço / natureza, isto é, à condição animalizada). Portanto, a perspectiva autoral, ao mediar as relações entre cortiço / natureza e sobrado / cultura, não logra alcançar a razão do trânsito da condição "animal” à condição “cultural”, condenando-a em termos “étnicos”, quando essa passagem de um “meio" a outro é de ordem sócio-econômica, e tem que ver, não com posições supostamente estamentais (como a sociedade colonial tendia a, narcisicamente, explicar-se), mas com a maior ou menor proximidade dos meios de produção (o que nada tem que ver com uma visão naturalizada da sociedade ou do "meio", a despeito da imagem narcísica).

A visão sobre o português / animal, provisoriamente nivelado ao negro / trabalhador no meio / natureza do cortiço / degradação, ao denunciar a contaminação recíproca entre negro / português pelo meio e pela condição animalizante do trabalho, embora recorra a um elemento de mediação que se quer, no plano das escolhas lingüísticas do texto, naturalizado, remonta, antes, a um contexto escravista, em que uma sociedade falsamente estamental de fato permitia a conquista da condição de elite, não pelo "homem livre” nacional, avesso ao trabalho degradante, mas pelo "português", provisoriamente nivelado ao "negro", tendo como fim a posse dos meios de produção e, com isso, a ascensão social. Desse modo, a auto-imagem narcísica da sociedade, de fato organizada pela proximidade ou pela distância dos meios-de-produção, mas 
ideologicamente organizada pelo trabalho / degradação ou pelo ócio / privilégio, se tomada no texto em si, tende a restringir a capacidade de interpretação à oscilação dicotômica entre os pólos natureza / cultura, em virtude do método de abordagem, cujo foco é a análise interna de elementos textuais.

Em outras palavras, o que, ideologicamente, organiza-se, no texto, como passagem do meio / natureza para o meio / cultura pelo fator pejorativo do trabalho / animalização, numa leitura interpretativa requer contextualizar-se, livrando-se do critério antinômico natureza / cultura para assumir o seu significado sociológico mais amplo, nas mediações textuais (e não de maneira imediata). Que a degradação promovida pelo trabalho numa sociedade escravista fosse naturalizada pelo olhar xenófobo de "homem livre" do escritor, isto não autoriza o método analítico a descuidar do salto interpretativo, que requer a compreensão do elemento mediador “trabalho”, não nos termos naturalizados que o texto sugere, mas nos termos contextualizados que a ótica narcísica da sociedade colonial impunha. Vale dizer que a compreensão do texto por seus elementos internos restringe-se, quando deixa escapar a transformação de elementos contextuais na organização de aspectos internos do texto, mediada pela forma lingüística, cuja natureza, a um tempo concreta e simbólica, estabelece uma correlação entre sociedade e estética nos termos de uma autonomia relativa.

Nas palavras do próprio crítico,

Um traço curioso do Estruturalismo é o que se poderia chamar de fixação com o número 2. A busca de modelos genéricos se associa nele a uma espécie de postulado latente de simetria, que o faz balançar-se entre cru e cozido, alto e baixo, frio e quente, claro e escuro, como se a ruptura da dualidade rompesse a confiança nele mesmo. Homologia, isomorfismo, até certo ponto isotopia são conceitos decorrentes (e nem sempre suficientemente esclarecidos), que convergem para o mesmo alvo. Talvez porque entre dois o espírito localize mais facilmente o ponto intermédio e eqüidistante, que serve de apoio para o compasso dos esquemas.

No entanto, há no pensamento do homem outros ritmos e outras implicações numéricas, como as que privilegiam o número 3. Não como expressão de um ponto neutro intercalado entre 1 e 1 ; mas como $1+1+1$, em pé de igualdade, como elementos constitutivos da visão. Neste sentido, o Marxismo é eminentemente triádico, a partir da dialética de Hegel, sendo por isso mesmo capaz de mostrar que o ritmo tese-antítese-síntese pressupõe equilíbrios fugazes; $e$ isto permite dar conta dos conjuntos irregulares, mantendo um reflexo mais fiel da irregularidade dos fatos, que os esquemas diádicos tendem a simplificar, preferindo à visão dinâmica do processo a contemplação estática dos sistemas em equilíbrio.

\section{(...)}


Estas divagações foram motivadas pela idéia que nas análises estruturalistas o 2 freqüentemente desliza ou deveria deslizar para o 3. Não o falso 3, igual ao ponto eqüidistante que marca a simetria, e que para Jakobson é, nos poemas, uma espécie de lugar mágico do significado. Mas o 3 verdadeiro, no qual as unidades (reais ou virtuais) se encontram em pé de igualdade. Quando as ditas análises não deixam vislumbrar o deslizamento e se fecham realmente na díade antinômica, temos as mais das vezes um sentimento de que falta alguma coisa para completar o panorama. ${ }^{347}$

Estes foram os pressupostos teórico-metodológicos que procuramos ter em mente, ao ler os poemas de A rosa do povo, e ao levar em consideração as contribuições de sua notável fortuna crítica. Segundo as especificidades da própria obra, nem história nem linguagem são categorias passíveis de uma abordagem que tome o texto em si, desvinculado do contexto, a um tempo literário e extra-literário, incorporado ao ato figurativo já no plano do enunciado.

Compreender as mediações entre texto e contexto pela especificidade do lirismo drummondiano, não nos termos de uma oscilação antinômica entre forma e comunicação, mas nos termos da superação artística de uma realidade em que estética e política revelam-se ideologicamente como planos contraditórios e apartados, esse consistiu no problema fundamental de nossa pesquisa.

${ }^{347}$ Idem, ibidem, p. 787-788. 


\section{BIBLIOGRAFIA}




\section{BIBLIOGRAFIA}

\section{Obras de Carlos Drummond de Andrade}

DRUMMOND DE ANDRADE, Carlos. Antologia poética. São Paulo: Abril Cultural, 1982.

_. Confissões de Minas. Rio de Janeiro: Americ-Edit, 1944.

. A lição do amigo. Cartas de Mário de Andrade a Carlos Drummond de Andrade, anotadas pelo destinatário. Rio de Janeiro: Record, 1982.

. O observador no escritório. Rio de Janeiro: Record, 1985.

_. Passeios na ilha. Divagações sobre a vida literária e outras matérias. Rio de Janeiro: Organização Simões, 1952.

_. Uma pedra no meio do caminho. Biografia de um poema. Rio de Janeiro: Ed. do Autor, 1967.

. Poesia completa e prosa. Rio de Janeiro: José Aguilar Editora, 1973, $3^{\mathrm{a}}$ ed.

. A rosa do povo, 1. ed. Rio de Janeiro: José Olympio, 1945.

. Tempo, vida, poesia: confissões no rádio. Rio de Janeiro: Record, 1986.

\section{Obras sobre Carlos Drummond de Andrade:}

ACHCAR, Francisco. Lírica e lugar comum. São Paulo: Edusp, 1995.

ANDRADE, Mário de. “A poesia de 30”. In: Aspectos da literatura brasileira. São Paulo: Martins, 1960.

ARRIGUCCI Jr., Davi. Coração partido. São Paulo: Cosac \& Naify, 2002.

BOSI, Alfredo. “ ‘A máquina do mundo’ entre o símbolo e a alegoria”. In: Céu, inferno. São Paulo: Ática, 1988.

_ _ "VIII. Tendências contemporâneas. O modernismo e o Brasil depois de 30”. In: História concisa da literatura brasileira. São Paulo: Cultrix, 1970.

BRAYNER, Sônia (org.) Carlos Drummond de Andrade - Coleção Fortuna Crítica (direção de A. Coutinho), n 1, 2a ed. Rio de Janeiro: Civilização Brasileira, 1978. 
BUARQUE DE HOLANDA, Sérgio. "Rebelião e convenção - I”, "Rebelião e convenção - II”, “O mineiro Drummond - I”, “O mineiro Drummond - II”. In: O espírito e as letras: estudos de crítica literária. São Paulo: Companhia das Letras, 1996, vol. 2.

CAMILO, Vagner. Drummond: Da Rosa do Povo à Rosa das Trevas. São Paulo: Ateliê Editorial, 2001.

CAMPOS, Haroldo de. “Drummond: mestre de coisas”. In: Metalinguagem. São Paulo: Cultrix, 1976.

CANÇADO, José Maria. Os sapatos de Orfeu. Biografia de Carlos Drummond de Andrade. São Paulo: Scritta Editorial, 1993.

CANDIDO, Antonio. “Drummond prosador”, “Fazia frio em São Paulo”. In: Recortes. São Paulo: Companhia das Letras, 1993.

—. "Inquietudes na poesia de Drummond”. In: Vários escritos, 3. ed. rev. amp. São Paulo: Duas Cidades, 1995.

_. "Poesia e ficção na autobiografia”. In: A Educação pela Noite \& Outros Ensaios. São Paulo: Ática, 1987.

CARPEAUX, Otto Maria. “Fragmento sobre Carlos Drummond de Andrade”. In: Origens e fins. Rio de Janeiro: Editora da Casa do Estudante do Brasil, 1943.

_. "O poeta e as moscas”. In: Livros na mesa. Rio de Janeiro: Livraria São José, 1960.

CASTELLI, Chantal. Lembranças em conflito: Poesia, Memória e História em Boitempo. São Paulo: FFLCH - USP, Dissertação de Mestrado, 2002.

CASTRO CORREIA, Marlene de. Drummond: a magia lúcida. Rio de Janeiro: Jorge Zahar Editor, 2002.

COELHO, Joaquim Francisco. Terra e família na poesia de Carlos Drummond de Andrade. Belém: Universidade Federal do Pará, 1973.

COSTA LIMA, Luiz. “O princípio-corrosão na poesia de Carlos Drummond de Andrade”. In: Lira e antilira: Mário, Drummond, Cabral. Rio de Janeiro: Topbooks, 1995.

FERREIRA CURY, Maria Zilda. Horizontes modernistas. O jovem Drummond e seu grupo em papel jornal. Belo Horizonte: Autêntica, 1998.

. (org.) Drummond: poesia e experiência. Belo Horizonte: Autêntica, 2002.

GARCIA, Othon Moacyr. Esfinge clara: palavra-puxa-palavra em Carlos Drummond de Andrade. Rio de Janeiro: São José, 1955. 
GLEDSON, John. Poesia e poética em Carlos Drummond de Andrade. São Paulo: Duas Cidades, 1981.

HOUAISS, Antonio. Drummond mais seis poetas e um problema. Rio de Janeiro: Imago, 1976.

MARTINS, Hélcio. A rima na poesia de Carlos Drummond de Andrade. Rio de Janeiro: José Olympio, 1968.

MENDONÇA TELLES, Gilberto de Mendonça. Drummond: a estilística da repetição. Rio de Janeiro: José Olympio, 1970.

MERQUIOR, José Guilherme. Verso universo em Drummond. Rio de Janeiro: José Olympio/SECCT, 1975.

MILLIET, Sérgio. Diário crítico. São Paulo: Martins, 1955.

MORAES, Emanuel de. Drummond rima Itabira mundo. Rio de Janeiro: José Olympio, 1972.

MORAES NETO, Geneton. O dossiê Drummond.Rio de Janeiro: Globo, 1994.

MOURA, Murilo M. Três poetas brasileiros e a Segunda Guerra Mundial (Carlos Drummond de Andrade, Cecília Meireles e Murilo Mendes). São Paulo: FFLCH USP, Tese de Doutoramento,1998.

NAVA, Pedro. Beira-Mar. Rio de Janeiro: Nova Fronteira, 1979, $2^{\mathrm{a}}$. ed.

PIGNATARI, Décio. Contracomunicação. São Paulo: Perspectiva, 1971.

PRADO JUNIOR, Bento. “O boi e o marciano”. In: Alguns ensaios. Rio de Janeiro: Paz e Terra, 2000.

PY, Fernando. Bibliografia comentada de Carlos Drummond de Andrade (1918-1930). Rio de Janeiro: José Olympio, 1980.

SAID, Roberto. A angústia da ação: poesia e política em Drummond. Belo Horizonte / Curitiba: Ed. UFMG / Ed. UFPR, 2005.

SANT'ANNA, Afonso Romano de. Drummond: o Gauche no tempo. RJ: Record, 1992. SANTIAGO, Silviano. Carlos Drummond de Andrade. Petrópolis: Vozes, 1976.

SIMON, Iumna Maria. Drummond: uma poética do risco. São Paulo: Ática, 1978.

VIEIRA LIMA, Mirella. Confidência mineira: o amor na poesia de Carlos Drummond de Andrade. São Paulo: Ática, 1995.

VILLAÇA, Alcides. Consciência lírica em Drummond. São Paulo: FFLCH - USP, Dissertação de Mestrado, 1976.

—_ “Capítulo drummondiano”. In: Lendo poetas brasileiros. São Paulo: FFLCH USP, Tese de Livre-Docência, 1999. 


\section{Obras de análise historiográfica ou sociológica:}

BOMENY, Helena. Guardiães da razão. Modernistas mineiros. Rio de Janeiro: UFRJ/Tempo Brasileiro, 1994.

BUARQUE DE HOLANDA, Sérgio (org.). História Geral da Civilização Brasileira. Tomo III, vol. 4. São Paulo: Difel, 1977.

CARONE, Edgar. O Estado Novo (1937-1945). São Paulo: Difel, 1977.

CERTEAU, Michel et alli. A invenção do cotidiano. Trad. Ephraim Ferreira Alves. Petrópolis: Vozes, 1996, 2 vols.

CROUZET, Maurice. História Geral das civilizações, vols. XV-XVII. São Paulo: Difel, 1977.

DIAS, Maria Odila Leite da Silva. "Hermenêutica do quotidiano na historiografia contemporânea”. In: Projeto História. São Paulo, nov. 1998.

Eli DINIZ, “O Estado Novo: estrutura de poder, relações de classe”, in: FAUSTO (org.). História Geral da Civilização Brasileira, III, Vol. 3. São Paulo: Difel, 1977.

GOMES, Ângela et alli. Capanema: o ministro e seu ministério. Rio de Janeiro: FGV, 2000 .

GUINZBURG, Carlo. Mitos, emblemas, sinais. São Paulo: Companhia das Letras, 1990.

HELLER, Agnes. O cotidiano e a história. Trad. Nelson Coutinho e Lenadro Konder. Rio de Janeiro: Paz e Terra, 1985. 2. ed.

HOBSBAWM, Eric. Era dos extremos. O breve século XX: 1914-1991. Trad. Marcos Santarrita. São Paulo: Companhia das Letras, 1995.

JOLL, James. Anarquistas e anarquismo. Lisboa: Quixote, 1981.

LEFEBVRE, Henri. La vida cotidiana en el mundo moderno. Madrid: Alianza Editorial, 1972.

MICELI, Sérgio. Intelectuais e classe dirigente no Brasil (1920-1945). São Paulo: Difel, 1979.

PIMENTEL PINTO FILHO, Júlio César. Borges, uma memória do mundo. Ficção, memória, história. São Paulo: FFLCH - USP, Tese de Doutoramento, 1995.

SCHWARTZMAN, Simon (org.). Estado Novo, um auto-retrato. Brasília: CPDOC/FGV, 1983. 
SCHWARTZMAN, Simon et alli. Tempos de Capanema. São Paulo: Edusp/Paz e Terra, 1984.

SIMON, Iumna Maria. Drummond, uma poética do risco. São Paulo: Ática, 1978.

SEVCENKO, Nicolau. Literatura como missão. Tensões sociais e criação cultural na Primeira República. São Paulo: Brasiliense, 1983.

_. Orfeu extático na metrópole. São Paulo, sociedade e cultura nos frementes anos 20. São Paulo: Companhia das Letras, 1991.

SILVA, Marcos Antonio da. Caricata república: Zé Povo e o Brasil. São Paulo: Marco Zero / CNPq, 1990.

_.. Prazer e poder do Amigo da Onça. Rio de Janeiro: Paz e Terra, 1985.

Rir das ditaduras - Os dentes de Henfil: ensaios sobre Fradim. São Paulo: FFLCH - USP, Tese de Livre-Docência, 2000.

__ . “Rimbaud e a Comuna de Paris”. In: Revista Adusp, no. 24. São Paulo: dez/2001. “O trabalho da linguagem”. In: Revista brasileira de história, vol. 6, no. 11. São Paulo: Anpuh/Marco Zero, 1986.

STAROBINSKI, Jean. “A literatura: o texto e o seu intérprete”. In: LE GOFF, Jacques e NORA, Pierre. História: novas abordagens. Trad. Henrique Mesquita. Rio de Janeiro: Francisco Alves, 1976.

TUCCI CARNEIRO, Maria Luíza. O anti-semitismo na Era Vargas.. São Paulo: Brasiliense, 1988.

VELOSO, Mônica Pimenta et alli. Estado Novo: ideologia e poder. Rio de Janeiro: Zahar, 1982.

VESENTINI, Carlos Alberto. A teia do fato. São Paulo: Hucitec, 1997.

WOODCOCK, George. Os grandes escritos anarquistas. Porto Alegre: L\&PM, 1981.

\section{Outras obras consultadas:}

ADORNO, Theodor W. Notas de literatura. Trad. Jorge de Almeida. São Paulo: Duas Cidades / Ed. 34, 2003.

ALVES DE AGUIAR, Joaquim. Espaços da memória. Um estudo sobre Pedro Nava. São Paulo: Edusp/FAPESP, 1988. 
AUERBACH, Erich. Mimesis. A representação da realidade na literatura ocidental. São Paulo, Perspectiva, 1976.

. "The aesthetic dignity of the 'Fleurs du mal' ". In: Scenes from the drama of european literature.Six essays. Gloucester: Peter Smith, 1973.

BAKHTIN, Mikhail. A cultura popular na Idade Média e no Renascimento. O contexto de François Rabelais. Trad. Yara Frateschi. São Paulo / Brasília: Hucitec / Edunb, 1996.

Problemas da poética de Dostoiévski. Rio de Janeiro: Forense Universitária, 1981.

BENKO, Susana. Vicente Huidobro y el cubismo. Caracas/Cidade do México, Monte Avila/Fondo de Cultura Económica, 1993.

BENJAMIN, Walter. Obras escolhidas, vol. 1: Magia e técnica, arte e política. São Paulo: Brasiliense, 1987, $3^{\mathrm{a}}$ ed.

_. Obras escolhidas, vol. 2: Rua de mão única: ensaios sobre literatura e história da cultura. São Paulo: Brasiliense, 1995, $5^{\mathrm{a}}$ ed.

. Obras escolhidas, vol. 3: Charles Baudelaire: um lírico no auge do capitalismo. São Paulo: Brasiliense, 1989.

Bíblia Sagrada. Ludovico Garmus (coord.) Trad. Domingos Samagna et alli. Petrópolis: Vozes, 1984.

BOSI, Alfredo. Leitura de poesia. São Paulo: Ática, 1996.

_. O ser e o tempo da poesia. São Paulo: Cultrix/Edusp, 1977.

BUARQUE DE HOLANDA. Raízes do Brasil. São Paulo: Companhia das Letras, 2005, $26^{\mathrm{a}}$ ed.

CANDIDO, Antonio. Brigada Ligeira e outros ensaios. São Paulo: Unesp, 1992.

_. Teresina etc. Rio de Janeiro: Paz e Terra, 1980.

. O discurso e a cidade. São Paulo: Duas Cidades, 1993.

_. Formação da literatura brasileira. Momentos decisivos. São Paulo / Belo Horizonte: Edusp / Itatiaia, 1975.

__. Literatura e sociedade. São Paulo: Companhia Editora Nacional, 1976.

Na sala de aula: caderno de análise literária. São Paulo: Ática, 1993.

. O estudo analítico do poema. São Paulo: FFLCH/USP, 1993.

. “A passagem do dois ao três”. In: Revista de história, ano XXV, vol. L, tomo III. São Paulo: s/ed., 1974.

_. "Plataforma da nova geração". In: Joaquim, no. 9, s/d. 
COHEN, Jean. "Poesia e redundância”. In: O discurso da poesia. Coimbra: Almedina, 1982.

CONCHA, Jaime (prólogo, seleção e notas). Vicente Huidobro. Madri, Jucar, 1980.

COSTA, René de. Huidobro: los oficios de un poeta. México, Fondo de Cultura Económica, 1984.

CRESSOT, Marcel. O estilo e suas técnicas. Lisboa: Edições 70, s/d.

ENKVIST, Nils Erik, GREGORY, Michael J., SPENCER, John. Lingüística e estilo. São Paulo: Cultrix/Edusp, 1964.

HERMANN, Fábio. Psicanálise do cotidiano. Porto Alegre: Artes Médicas, 1997.

JAKOBSON, Roman. Lingüística. Poética. Cinema. Trad. Francisco Achcar. São Paulo: Perspectiva,1980.

JORDAN, Isolde. Introducción al análisis lingüístico del discurso. Wilhelmsfeld: Egert, 1994.

LAFETÁ, João Luís. 1930: a crítica e o modernismo. São Paulo: Duas Cidades, 1974.

LEVINE, Samuel R. Estruturas lingüísticas em poesia. São Paulo: Cultrix/Edusp, 1975.

LIMA, Carlos (org.). Rimbaud no Brasil. Rio de Janeiro: UERJ / Comunicarte, 1993.

MANN, Thomas. A Montanha Mágica. Trad. Herbert Caro. Rio de Janeiro: Nova Fronteira, 2000, $2^{\mathrm{a}}$ ed.

PAZ, Octavio. O arco e a lira. Rio de Janeiro: Nova Fronteira, 1982.

RAMOS, Graciliano. Memórias do cárcere. Rio de Janeiro: Record, 1984, $17^{\mathrm{a}}$ ed, 2 vols.

SARTRE, Jean-Paul. Que é Literatura? Trad. Carlos Felipe Moisés. São Paulo: Ática, 1993.

SCHWARZ, Roberto. Um mestre na periferia do capitalismo: Machado de Assis. São Paulo: Duas Cidades, 1990.

TINIANOV, Youri. “Os traços flutuantes da significação do verso”. In: O discurso da poesia. Coimbra: Almedina, 1982.

YURKIEVICH, Saúl. Fundadores de la nueva poesia latinoamericana. Vallejo, Huidobro, Borges, Girondo, Neruda, Paz. Barcelona: Barral, 1970. 